\title{
Site ${\mathrm{M} 0063^{1}}^{1}$
}

T. Andrén, B.B. Jørgensen, C. Cotterill, S. Green, E. Andrén, J. Ash, T. Bauersachs, B. Cragg, A.-S. Fanget, A. Fehr, W. Granoszewski, J. Groeneveld, D. Hardisty, E. Herrero-Bervera, O. Hyttinen, J.B. Jensen, S. Johnson, M. Kenzler, A. Kotilainen, U. Kotthoff, I.P.G. Marshall, E. Martin, S. Obrochta, S. Passchier, N. Quintana Krupinski, N. Riedinger, C. Slomp, I. Snowball, A. Stepanova, S. Strano, A. Torti, J. Warnock, N. Xiao, and R. Zhang ${ }^{2}$

\section{Chapter contents}

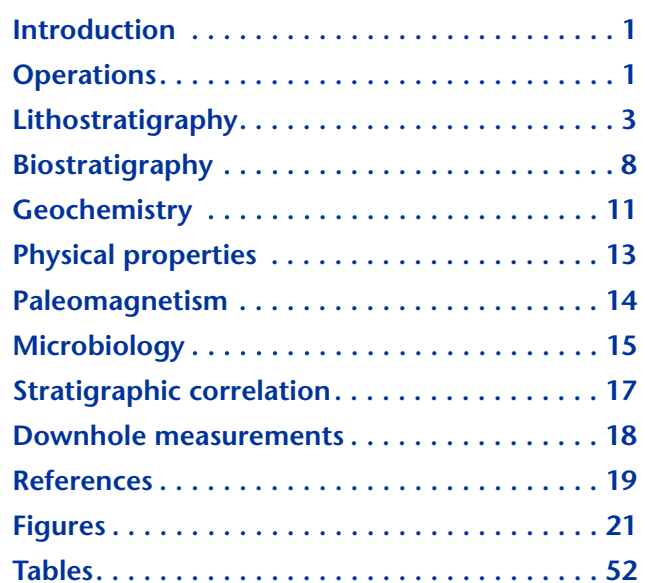

${ }^{1}$ Andrén, T., Jørgensen, B.B., Cotterill, C., Green, S., Andrén, E., Ash, J., Bauersachs, T., Cragg, B., Fanget, A.-S., Fehr, A., Granoszewski, W., Groeneveld, J., Hardisty, D., Herrero-Bervera, E., Hyttinen, O., Jensen, J.B., Johnson, S., Kenzler, M., Kotilainen, A., Kotthoff, U., Marshall, I.P.G., Martin, E., Obrochta, S., Passchier, S., Quintana Krupinski, N., Riedinger, N., Slomp, C., Snowball, I., Stepanova, A., Strano, S., Torti, A., Warnock, J., Xiao, N., and Zhang, R., 2015. Site M0063. In Andrén, T., Jørgensen, B.B., Cotterill, C., Green, S., and the Expedition 347 Scientists, Proc. IODP, 347: College Station, TX (Integrated Ocean Drilling Program).

doi:10.2204/iodp.proc.347.107.2015

'Expedition 347 Scientists' addresses.

\section{Introduction}

During Integrated Ocean Drilling Program (IODP) Expedition 347, cores were recovered from five holes at Site M0063 (Landsort Deep), with an average site recovery of $97.9 \%$. The water depth was $437.1 \mathrm{~m}$, with a tidal range of $<10 \mathrm{~cm}$. Existing data sets, including seismic reflection profiles, were evaluated prior to each site to attempt to guide the initial drilling with an anticipated lithologic breakdown. The total time spent on station was 10.76 days.

\section{Operations}

\section{Transit to Hole M0063A}

The vessel began the transit to Site M0063 (proposed Site BSB-9) at $1945 \mathrm{~h}$ on 6 October 2013 when the pilot boarded the Greatship Manisha. The vessel arrived on station over Hole M0063A at $0225 \mathrm{~h}$ on 8 October and began preparations for coring (Table T1).

\section{Hole M0063A}

During preparations for coring in Hole M0063A, a discrepancy in the depths submitted by the two transponders deployed on the seabed template was noted. Therefore, additional caution was exercised when tagging the seafloor and taking the first core. A $1 \mathrm{~m}$ push sample was conducted to gauge the true mudline depth. Following this, seven piston cores were recovered before a problem with a spline from the overshot messenger ceased coring operations. Fishing attempts were unsuccessful, so the pipe was tripped back to the point at which the spline and core barrel were lodged. During the early hours of 9 October 2013, the partial pipe trip successfully recovered the core barrel and intact core and pipe was run back down to the previously cored depth. Two further piston cores were successfully recovered to deck, but the third again became stuck as the overshot release sleeve became jammed in the pipe. On this occasion, the fishing attempt was successful, and the pipe did not have to be tripped. Modifications were made to the overshot release system, and coring continued successfully for the remainder of 9 October and into 10 October, with a further 19 cores being recovered to deck.

Following recovery of Core $29 \mathrm{H}$, a change in lithology meant the next piston core took three attempts and flushing of the hole to 
free it from the bottom-hole assembly (BHA). The following two piston cores had good recovery. Because of encountering a till lithology, it was decided to change to the extended nose system. However, from this point onward and despite trying different coring systems, recovery and penetration continued to be low. After discussion with the Co-Chief Scientists, it was decided to open hole sections with spot sampling to try to progress through the till unit. This continued until midnight.

At midnight on 10 October, a coarse gravel lithology was encountered. After $10 \mathrm{~m}$, a hammer sample was taken, which returned $1 \mathrm{~cm}^{3}$ of material. At $0150 \mathrm{~h}$, it was decided that the hole was no longer viable because of the risk of caving and stuck pipe. Preparations then began for downhole logging. Pipe was brought up to 18 meters below seafloor (mbsf), and logging sheaves were set up.

Logging preparations commenced at $0150 \mathrm{~h}$, with the drill string being tripped to 18.5 mbsf. The first tool string consisted of the compact gamma ray and compact induction tools. The tool string was run down the hole at $0322 \mathrm{~h}$ and downward logging began at $0340 \mathrm{~h}$. The first uplog commenced at $0349 \mathrm{~h}$ from 108.5 mbsf and ended at $0404 \mathrm{~h}$, with the tool recovered on deck at $0440 \mathrm{~h}$. The second run included the compact gamma ray, compact spectral gamma, and compact sonic tools and commenced at $0451 \mathrm{~h}$ when the tool was run into the hole. The tool string also reached a maximum depth of 108.5 mbsf. The third run included the compact gamma ray and compact microimager tools. This tool string was run into the hole at $0628 \mathrm{~h}$, and the maximum depth of 108.5 mbsf was again reached. The uplog began at $0701 \mathrm{~h}$ and ended at $0727 \mathrm{~h}$. Rig down was complete by $0830 \mathrm{~h}$, and the vessel prepared to move to Hole M0063B.

A total of 38 cores were recovered in Hole M0063A, with three open-hole sections, reaching a maximum depth of 115.81 mbsf. Hole recovery was $92.89 \%$ when the open-hole sections were discounted.

\section{Hole M0063B}

Cores from Hole M0063A expanded significantly upon reaching the deck, and there was a resultant loss of core material upon removal of the piston. The coring strategy for Hole M0063B was therefore modified to maximize the amount of sediment recovered. The new strategy involved penetrating $2 \mathrm{~m}$ into the sediment for each $3.3 \mathrm{~m}$ run to allow room in the liner for expansion of the sediments without incurring sediment loss. This involved pulling back $1.3 \mathrm{~m}$ from the base of each washed-out interval before fir- ing the piston corer system (PCS). Following each PCS sample run, the BHA was advanced by $2 \mathrm{~m}$. Although this reduced the production rate, it proved very successful in collecting higher quality cores with no loss of sediment. This process continued successfully for 14 piston coring runs before the hole was terminated and preparations were made for transit to the midterm port call.

A total of 14 cores were recovered in Hole M0063B, reaching 29.0 mbsf. Hole recovery was $99.28 \%$.

Following completion of Hole M0063B, the drill floor and containers were secured for transit and the Greatship Manisha sailed for the port of Nynäshamn, arriving at $0730 \mathrm{~h}$ on 12 October 2013. Once alongside, provisions, drilling mud, and spares were brought on board and frozen microbiology samples were offloaded to World Courier. The vessel departed Nynäshamn at 1730 h, sailing back to Site M0063.

\section{Hole M0063C}

The vessel arrived on station at $2115 \mathrm{~h}$ on 12 October 2013. By $0215 \mathrm{~h}$ on 13 October, the drill string, collars, and BHA were run to just above the seabed. Coring then commenced, with 22 successful piston core runs on 13 October. To maximize the recovery of the expanding sediments, the same strategy used in Hole M0063B was again adopted, whereby the PCS was pulled back $1.3 \mathrm{~m}$ from the base of each washed-out interval before firing the PCS. Following each PCS sample run, the BHA was advanced by $2 \mathrm{~m}$. This procedure continued to provide the most complete sequence within this expanding sediment package.

Coring with the PCS continued smoothly on 14 October. At $93.3 \mathrm{mbsf}$, till was encountered that prevented a full $3.3 \mathrm{~m}$ piston stroke being achieved. It was decided to open hole $3 \mathrm{~m}$ and take a hammer sample. This confirmed that coring had progressed into a diamicton, and the decision was made to terminate the hole at $1720 \mathrm{~h}$ on 14 October. Preparations were then made to bump over to Hole M0063D to establish a new hole.

A total of 40 cores were recovered from Hole M0063C, with one open-hole section, reaching a maximum depth of 96.40 mbsf. Hole recovery was $99.29 \%$ when the open-hole section was discounted.

\section{Hole M0063D}

Operations began in Hole M0063D at 1830 h on 14 October 2013. The first piston core was fired from $1.8 \mathrm{~m}$ above the seabed, creating an offset in core run depths between Holes M0063C and M0063D to aid stratigraphic correlation. 
Coring continued successfully for the remainder of 14 October and throughout 15 October. Again, the sediments recovered were highly gaseous and expanded significantly. PCS operations continued the morning of 16 October until Run 41 became stuck in the BHA at $86.8 \mathrm{mbsf}$ and attempts to free it proved unsuccessful, with the wireline string parting.

After discussion, as the hole was within $9 \mathrm{~m}$ of the expected depth for the clay to till transition, it was decided to terminate Hole M0063D at this point. The drill string was tripped, and the BHA was brought up to the slips. The core barrel was released, and the core was recovered for curation.

Problems with torquing the top subs resulted in the BHA being exchanged with a spare. The vessel then bumped across to the microbiology hole (M0063E), and preparations were made for coring, with running of pipe.

A total of 40 coring attempts were conducted in Hole M0063D, with one open-hole section, reaching a maximum depth of 86.8 mbsf. Hole recovery was $98.59 \%$ when the open-hole section was discounted.

\section{Hole M0063E}

The vessel bumped across to the microbiology hole (M0063E), and preparations were made for coring, with running of pipe commencing at $2020 \mathrm{~h}$ on 16 October 2013.

On 17 October, piston coring continued well throughout the day, with 21 cores recovered to deck. Initially, the coring rate was adjusted to enable microbiological sampling to keep pace, but the rate returned to normal after the first six cores as the intensive sampling scheme reduced with depth.

Coring continued well throughout the morning of 18 October with eight piston cores recovered to deck. However, by $0900 \mathrm{~h}$, winds and sea swell had built to such an extent that tool handling on the drill floor became unsafe. Operations were therefore suspended, waiting on weather until $1645 \mathrm{~h}$, when coring operations recommenced, with a further eight piston cores recovered to deck by midnight.

The hole ended at $92.8 \mathrm{mbsf}$ at $0610 \mathrm{~h}$ on 19 October following the recovery of a till lithology. A total of 43 cores were recovered, with one open-hole section. Hole recovery was $99.69 \%$ when the open-hole section was discounted.

\section{Lithostratigraphy}

At a water depth of $437 \mathrm{~m}$, Site M0063 in the Landsort Deep is the deepest location drilled during Expedition 347, in the deepest basin of the Baltic Sea. Five holes were drilled: Hole M0063A to a total depth of 115.81 mbsf, Hole M0063B to 29.00 mbsf, Hole M0063C to $96.4 \mathrm{mbsf}$, Hole M0063D to $86.8 \mathrm{mbsf}$, and Hole M0063E to 92.8 mbsf.

Piston coring was used in Holes M0063A-M0063E, except at the bottom of Holes M0063A and M0063C, where it became difficult because of the harder lithology of suspected diamicton. In Hole M0063A, an extended nose system was attempted, but recovery and penetration was low because of the highly variable lithology. In order to progress through the diamict, open-hole sections with spot sampling were carried out. At the base of the borehole, a hard layer was encountered, and hammer sampling recovered a granite rock $\sim 5 \mathrm{~cm}$ in diameter (see "Operations").

During coring operations in Hole M0063A, problems were encountered because of the presence of methane gas-charged sediments. Pressure induced by a water depth of $437 \mathrm{~m}$ along with organic-rich sediments were responsible for extreme gas expansion, resulting in disturbed core sections in the form of sediment outburst and soupy intervals to frequent bubbles and cracks that were visible through the core liners to $\sim 50$ mbsf.

The higher than expected expansion of the cores upon reaching the deck and the resultant loss of core material upon removal of the piston from Hole M0063A resulted in an alternative coring strategy. In the following holes, the piston coring system was pulled back $1.3 \mathrm{~m}$ from the base of each washed out interval before firing (see "Operations"). This procedure reduced the borehole advance to $2 \mathrm{~m}$ per core run but provided the most complete sequence within the expanding sediment package. Core recovery was exceedingly high, as much as $185 \%$ in the uppermost meters and $\sim 150 \%$ on average at $\sim 30$ mbsf. At $\sim 55 \mathrm{mbsf}$, core recovery returned to $\sim 100 \%$, and depth increments were increased to the normal $3.3 \mathrm{~m}$ run.

The changes in procedure proved successful in Holes M0063B and M0063C and were therefore applied to Hole M0063D in order to secure a continuous stratigraphy and varve record. In the upper $20 \mathrm{~m}$, methane gas escape remained a problem, resulting in moderately to highly disturbed sediments, and horizontal cracks were commonly found. The cored intervals were coordinated with earlier holes using stratigraphic correlation to obtain the most complete composite record of sediment with a good varve resolution ranging from the modern anoxic Landsort Deep through the Holocene and into late glacial clay.

Hole M0063E was dedicated to microbiological sampling to $\sim 90$ mbsf. To avoid errors associated with ex- 
panding sediments, $2 \mathrm{~m}$ cores were taken to $54 \mathrm{mbsf}$. In doing so, it was assumed that the sediment would expand inside the core liner rather than beyond it, therefore reducing the amount of sediment lost and increasing availability for sampling purposes.

Lithostratigraphic divisions at Site M0063 are based on descriptions of the cut face of the split core from Hole M0063D, as this is the most complete combined record of Holocene and late glacial sediments with an adjusted core recovery of nearly 99\%. Supporting supplementary information is collected from the other Site M0063 holes, in particular from the deepest parts of Holes M0063A and M0063C. Information from smear slides from all holes is also included.

Site M0063 is divided into seven lithostratigraphic units (Fig. F1). Unit I (0-25 mbsf) is composed of organic-rich diatom-bearing clays with subunits of weakly laminated intervals and prominently laminated intervals. Unit II (25-33 mbsf) is gray clay with an upper subunit dominated by iron sulfide lamination and a lower subunit of massive gray clay. A thin sand lamina indicates the shift to Unit III (33-41 mbsf), which comprises two subunits characterized by mixed clay sediments and contorted laminae. Unit IV (41-48 mbsf) is an iron sulfide-laminated gray clay subunit that gradually changes with depth to grayish brown varved clay. Unit V (48-53 mbsf) is contorted, convolute bedded clay. Unit VI (53-93 mbsf) is finely laminated varved clay with a downcore increase in the content of silt and sand demonstrated by thicker laminae and dispersed pebble content. The deepest part of the site is Unit VII (93-96 mbsf), which comprises sandy diamict. From 96 mbsf to the final depth of 115.8 mbsf (Hole M0063A), core recovery was very low. This, combined with water logging and the mixed character of the cores, made it impossible to resolve an interpretation of lithology. However, it is highly possible that the lithology represents a continuation of Unit VII to the bottom of Hole M0063A.

Normal IODP procedure where expansion is concerned is to assign the top of a core to the depth of the base of the last core run and let the cores overlap. However, this is not useful when documenting lithostratigraphy. Therefore, in this section we have attempted to assign a linear compression factor to the expanded cores to avoid this overlap. Depths in the subsequent unit descriptions will therefore be given following the IODP noncompressed depths and the corrected compressed depths. These depths were recalculated using

Recalculated depth $=$ (recovered core length $/$ percentage recovery) + top depth of that core run.

\section{Unit I}

\section{Subunit la}

Intervals: 347-M0063A-1P-1, $0 \mathrm{~cm}$, to $3 \mathrm{H}-1,24 \mathrm{~cm}$; $347-\mathrm{M} 0063 \mathrm{~B}-1 \mathrm{H}-1,0 \mathrm{~cm}$, to $3 \mathrm{H}-1,134 \mathrm{~cm} ; 347-$ M0063C-1H-1, $0 \mathrm{~cm}$, to $3 \mathrm{H}-1,10 \mathrm{~cm} ; 347-$ M0063D-1H-1, $0 \mathrm{~cm}$, to $3 \mathrm{H}-2,20 \mathrm{~cm}$; Hole M0063E microbiology sampling only

Depths: Hole M0063A $=0-3.54$ mbsf; Hole M0063B = 0-5.34 mbsf; Hole M0063C $=0-4.10$ mbsf; Hole M0063D = 0-4.81 mbsf

Recalculated depths if recovery is $>100 \%$ : Hole M0063B $=0-5.03$ mbsf; Hole M0063C $=0-4.08$ mbsf; Hole M0063D = 0-4.34 mbsf

\section{Subunit Ib}

Intervals: $347-\mathrm{M} 0063 \mathrm{~A}-3 \mathrm{H}-1,24 \mathrm{~cm}$, to $4 \mathrm{H}-1,36$ $\mathrm{cm}$; 347-M0063B-3H-1, $134 \mathrm{~cm}$, to $4 \mathrm{H}-2,104$ $\mathrm{cm}$; 347-M0063C-3H-1, $10 \mathrm{~cm}$, to $4 \mathrm{H}-1,70 \mathrm{~cm}$; 347-M0063D-3H-2, $20 \mathrm{~cm}$, to 3H-3, $50 \mathrm{~cm}$; Hole M0063E below microbiology sample

Depths: Hole M0063A = 3.54-6.96 mbsf; Hole M0063B $=5.34-7.89$ mbsf; Hole M0063C = 4.10-6.70 mbsf; Hole M0063D = 4.81-6.29 mbsf

Recalculated depths if recovery is $>100 \%$ : Hole $\mathrm{M} 0063 \mathrm{~B}=5.03-7.62$ mbsf; Hole $\mathrm{M0063 \textrm {C }}=$ 4.08-6.63 mbsf; Hole M0063D = 4.34-5.33 mbsf

\section{Subunit Ic}

Intervals: $347-\mathrm{M} 0063 \mathrm{~A}-4 \mathrm{H}-1,36 \mathrm{~cm}$, to $7 \mathrm{H}-2,70$ $\mathrm{cm}$; 347-M0063B-4H-2, $104 \mathrm{~cm}$, to $10 \mathrm{H}-1,92$ $\mathrm{cm}$; 347-M0063C-4H-1, $70 \mathrm{~cm}$, to $9 \mathrm{H}-2,32 \mathrm{~cm}$; 347-M0063D-3H-3, $50 \mathrm{~cm}$, to $10 \mathrm{H}-2,4 \mathrm{~cm}$; Hole M0063E below microbiology sample

Depths: Hole M0063A $=6.96-18.70$ mbsf; Hole M0063B $=7.89-19.92$ mbsf; Hole M0063C = 6.70-17.82 mbsf; Hole M0063D = 6.29-18.89 mbsf

Recalculated depths if recovery is $>100 \%$ : Hole $\mathrm{M} 0063 \mathrm{~B}=7.62-19.70$ mbsf; Hole $\mathrm{M} 0063 \mathrm{C}=$ 6.63-17.39 mbsf; Hole M0063D = 5.33-18.38 mbsf

\section{Subunit Id}

Intervals: $347-\mathrm{M} 0063 \mathrm{~A}-7 \mathrm{H}-2,70 \mathrm{~cm}$, to $9 \mathrm{H}-3,19$ $\mathrm{cm}$; 347-M0063B-10H-1, $92 \mathrm{~cm}$, to $13 \mathrm{H}-1,106$ $\mathrm{cm}$; 347-M0063C-9H-2, $32 \mathrm{~cm}$, to $13 \mathrm{H}-2,48 \mathrm{~cm}$; 347-M0063D-10H-2, $4 \mathrm{~cm}$, to $14 \mathrm{H}-1,20 \mathrm{~cm}$; Hole M0063E below microbiology sample

Depths: Hole M0063A = 18.70-25.99 mbsf; Hole M0063B $=19.92-26.06$ mbsf; Hole M0063C = 17.82-25.90 mbsf; Hole M0063D = 18.89-25.20 mbsf

Recalculated depths if recovery is $>100 \%$ : Hole $\mathrm{M0063 \textrm {A }}=18.70-25.76$ mbsf; Hole M0063B = 
19.70-25.68 mbsf; Hole M0063C = 17.39-25.18 mbsf; Hole M0063D = 18.38-25.16 mbsf

Unit I consists of organic-rich diatom-bearing clays comprising the uppermost 25.16 mbsf of Hole M0063D. An overall pattern of shifting weakly laminated (Subunits Ia and Ic) and prominently laminated (Subunits Ib and Id) intervals is visible. Unit I has a gradual lower boundary to less organic rich clays. Smear slide data (see "Core descriptions") typically show very minor contents of silt and sand, abundant opaque authigenic minerals, and the existence of large centric diatoms.

Subunit Ia consists of very well sorted black organicrich clay with many soupy intervals and cracks throughout the core. Because of the high degree of gas expansion, no primary sedimentary structures are visible. Strong oxidation is found along the core liner and cracks, with a color change to olive-gray.

In the best preserved intervals, black clay with a lamination color change at the millimeter scale and an organic algae mat-like appearance has been observed. Olive-colored oxidation is characteristic at the bottom of the section.

Subunit Ic is similar to Subunit Ia, very well sorted black organic-rich clay only showing weak lamination and uncommon bioturbation by color at the millimeter scale. The subunit, to a varying degree, is oxidized to a greenish gray color.

Subunit Id is the best preserved part of Unit I. The color ranges from full black to olive-gray and light yellowish brown. It is organic-rich clay with prominent laminations at the millimeter scale (Fig. F2). The sediment appears laminated, with single laminae of $\sim 1-5 \mathrm{~mm}$ and a possible cyclicity at the centimeter scale. A peaty smell was noticed in the very well sorted sediment.

The organic-rich clay with the shifting weak lamination and prominent algal mat-like lamination is possibly related to a shift between oxic and anoxic conditions in the marine Holocene sediments of the Baltic Sea (Zillén and Conley, 2010).

\section{Unit II}

\section{Subunit Ila}

Intervals: $347-\mathrm{M} 0063 \mathrm{~A}-9 \mathrm{H}-3,19 \mathrm{~cm}$, to $10 \mathrm{H}-1,0$ $\mathrm{cm}$; 347-M0063B-13H-1, $106 \mathrm{~cm}$, to $14 \mathrm{H}-1,50$ $\mathrm{cm}$; 347-M0063C-13H-2, $48 \mathrm{~cm}$, to $15 \mathrm{H}-1,0 \mathrm{~cm}$; $347-\mathrm{M} 0063 \mathrm{D}-14 \mathrm{H}-1,20 \mathrm{~cm}$, to $15 \mathrm{H}-1,100 \mathrm{~cm}$; Hole M0063E below microbiology sample

Depths: Hole M0063A = 25.99-26.10 mbsf; Hole M0063B $=26.06-27.50$ mbsf; Hole M0063C =
25.90-28.00 mbsf; Hole M0063D = 25.20-28.00 mbsf

Recalculated depths if recovery is $>100 \%$ : Hole $\mathrm{M} 0063 \mathrm{~A}=25.76-26.10$ mbsf; Hole M0063B = 25.68-27.35 mbsf; Hole M0063C $=25.18-28.00$ mbsf; Hole M0063D = 25.16-27.81 mbsf

\section{Subunit IIb}

Intervals: $347-\mathrm{M} 0063 \mathrm{~A}-10 \mathrm{H}-1,0 \mathrm{~cm}$, to $12 \mathrm{H}-1,105$ $\mathrm{cm}$; 347-M0063B-14H-1, $50 \mathrm{~cm}$, to end of hole; $347-\mathrm{M} 0063 \mathrm{C}-15 \mathrm{H}-1,0 \mathrm{~cm}$, to $17 \mathrm{H}-2,74 \mathrm{~cm}$; $347-\mathrm{M} 0063 \mathrm{D}-15 \mathrm{H}-1,100 \mathrm{~cm}$, to $18 \mathrm{H}-1,70 \mathrm{~cm}$; Hole M0063E below microbiology sample

Depths: Hole M0063A = 26.10-33.75 mbsf; Hole M0063B $=27.5-29.00$ mbsf; Hole M0063C = 28.00-34.24 mbsf; Hole M0063D = 28.00-33.70 mbsf

Recalculated depths if recovery is $>100 \%$ : Hole $\mathrm{M} 0063 \mathrm{~A}=26.10-33.64$ mbsf; Hole M0063B = 27.35-29.00 mbsf; Hole M0063C = 28.00-33.22 mbsf; Hole M0063D = 27.81-33.48 mbsf

In Unit II, the organic content is lower than in Unit I. The unit is divided into clay subunits because of a significant change from laminated to homogeneous sediment, a color shift from dark gray to gray, and intervals showing varying degrees of black sulfidic contents. Smear slide studies (see "Core descriptions") in the uppermost part of Subunit IIa show very low contents of silt and sand, opaque authigenic minerals, and large centric diatoms, whereas Subunit IIb shows a high silt content of quartz and feldspar composition, with iron oxide coatings on quartz and large mica flakes.

Subunit IIa is dark gray clay within which iron sulfide-stained, very dark gray weak lamination is visible at a millimeter-centimeter scale (Fig. F2). The clay is very well sorted.

In Subunit IIb, the lamination disappears and the clay is homogeneous gray and well sorted. The lower boundary shows soft-sediment deformation toward a thin sand layer.

In Unit II, sulfidization may be the result of breakdown of primary organic material in the laminations.

The heavy disturbance, especially of Subunit IIb, however, cannot hide a clear change from a homogeneous Subunit IIb to laminated Subunit IIa clay, indicating a gradual change in depositional environment toward basin sedimentation. The stratigraphic position of Unit II just deeper than the organically rich clay and the iron sulfide lamination has on previous occasions been documented as Ancylus Lake sediments (Ignatius et al., 1981). 


\section{Unit III}

\section{Subunit IIla}

Intervals: $347-\mathrm{M} 0063 \mathrm{~A}-12 \mathrm{H}-1,105 \mathrm{~cm}$, to $13 \mathrm{H}-1$, $60 \mathrm{~cm}$; 347-M0063C-17H-2, $74 \mathrm{~cm}$, to $19 \mathrm{H}-2,12$ $\mathrm{cm}$; 347-M0063D-18H-1, $70 \mathrm{~cm}$, to $18 \mathrm{H}-2,6 \mathrm{~cm}$; Hole M0063E below microbiology sample

Depths: Hole M0063A = 33.75-36.60 mbsf; Hole M0063C $=34.24-37.62$ mbsf; Hole M0063D = 33.70-34.56 mbsf

Recalculated depths if recovery is $>100 \%$ : Hole $\mathrm{M} 0063 \mathrm{~A}=33.64-36.51 \mathrm{mbsf}$; Hole M0063C = 33.22-37.12 mbsf; Hole M0063D = 33.48-34.07 mbsf

\section{Subunit IIIb}

Intervals: 347-M0063A-13H-1, $60 \mathrm{~cm}$, to $14 \mathrm{H}-2,55$ $\mathrm{cm}$; 347-M0063C-19H-2, $12 \mathrm{~cm}$, to $21 \mathrm{H}-2,0 \mathrm{~cm}$; $347-\mathrm{M} 0063 \mathrm{D}-18 \mathrm{H}-2,6 \mathrm{~cm}$, to $22 \mathrm{H}-1,64 \mathrm{~cm}$; Hole M0063E below microbiology sample

Depths: Hole M0063A = 36.60-41.35 mbsf; Hole M0063C $=37.62-41.50$ mbsf; Hole M0063D = 34.56-41.64 mbsf

Recalculated depths if recovery is $>100 \%$ : Hole $\mathrm{M} 0063 \mathrm{~A}=36.51-41.00$ mbsf; Hole M0063C = 37.12-40.90 mbsf; Hole M0063D = 34.07-41.43 mbsf

Unit III is composed of contorted clay deposits divided into two subunits. Both subunits show sharp lower boundaries and are upward bounded by centimeter-scale sand laminae.

The top of Subunit IIIa is a heavily deformed, few centimeter thick, well-sorted, medium-grained sand layer. Below the sand follows massive, moderately sorted gray clay with contents of silt and sand, as well as a few dispersed pebbles of $0.5-1 \mathrm{~cm}$ size. This subunit is moderately disturbed by coring.

As with Subunit IIIa, Subunit IIIb has an uppermost few centimeter thick, well-sorted, medium-grained sand layer followed by very well sorted clay with massive to convolute internal bedding structures and a sharp lower boundary. This subunit is slightly disturbed by coring. Smear slide data (see "Core descriptions") show minor contents of silt, abundant contents of opaque authigenic minerals, and traces of possible altered volcanic glass with stretched vesicles.

Subunit IIIa is classified as clay/silt with dispersed clasts, indicating slumping and mixing of sediments similar to Subunit IIIb and showing clear indications of displacements and contortion. The combination of contortion and thin sand layers can be interpreted as two slumping events coupled to basin currents. The presence of volcanic glass may be related to volcanic ash spreading events.

\section{Unit IV}

\section{Subunit IVa}

Intervals: 347-M0063A-14H-2, $55 \mathrm{~cm}$, to $15 \mathrm{H}-1,76$ $\mathrm{cm} ; 347-\mathrm{M} 0063 \mathrm{C}-21 \mathrm{H}-2,0 \mathrm{~cm}$, to $23 \mathrm{H}-1,100$ $\mathrm{cm}$; 347-M0063D-22H-1, $64 \mathrm{~cm}$, through $24 \mathrm{H}-1$, $56 \mathrm{~cm}$; Hole M0063E below microbiology sample

Depths: Hole M0063A $=41.35-43.36$ mbsf; Hole M0063C $=41.50-45.00$ mbsf; Hole M0063D = 41.64-45.06 mbsf

Recalculated depths if recovery is $>100 \%$ : Hole $\mathrm{M0063 \textrm {A }}=41.00-43.26$ mbsf; Hole M0063C = 40.90-44.66 mbsf; Hole M0063D = 41.43-44.86 mbsf

\section{Subunit IVb}

Intervals: $347-\mathrm{M} 0063 \mathrm{~A}-15 \mathrm{H}-1,76 \mathrm{~cm}$, to $16 \mathrm{H}-2,97$ $\mathrm{cm}$; 347-M0063C-23H-1, $100 \mathrm{~cm}$, to $24 \mathrm{H}-2,112$ $\mathrm{cm}$; 347-M0063D-24H-1, $56 \mathrm{~cm}$, to $25 \mathrm{H}-2,84$ $\mathrm{cm}$; Hole M0063E below microbiology sample

Depths: Hole M0063A $=43.36-48.37$ mbsf; Hole M0063C $=45.00-48.62$ mbsf; Hole M0063D = 45.06-48.84 mbsf

Recalculated depths if recovery is $>100 \%$ : Hole $\mathrm{M0063 \textrm {A }}=43.26-48.08$ mbsf; Hole M0063C = 44.66-47.80 mbsf; Hole M0063D = 44.86-47.97 mbsf

Unit IV is another laminated clay unit that gradually changes uphole from grayish brown lamination to gray with dark gray to black iron sulfide-stained lamination (Fig. F2).

Subunit IVa is very well sorted greenish gray clay with dark gray weak iron sulfide lamination on a $0.5-1 \mathrm{~cm}$ scale. Subunit IVa gradually changes downcore to Subunit IVb.

In Subunit IVb, very well sorted laminated clay continues, but the color changes to grayish brown and the laminae are thinner and recognized by millimeter- to centimeter-scale color banding. Smear slide data indicate nearly pure terrigenous clay.

The gradual change from brownish lamination in Subunit IVb to iron sulfide lamination in Subunit IVa may indicate a shift in sedimentary environment away from glacial influenced lacustrine varvic sedimentation. Marine imprint on the youngest glaciolacustrine deposits is well known in the Baltic Sea history as the brackish phase of the Yoldia Sea stage deposits (Wastegård et al., 1995).

\section{Unit V}

Intervals: $347-\mathrm{M} 0063 \mathrm{~A}-16 \mathrm{H}-2,97 \mathrm{~cm}$, to $18 \mathrm{H}-1,37$ $\mathrm{cm}$; 347-M0063C-24H-2, $112 \mathrm{~cm}$, to $26 \mathrm{H}-2,15$ 
$\mathrm{cm}$; 347-M0063D-25H-2, $84 \mathrm{~cm}$, to $28 \mathrm{H}-1,90$ $\mathrm{cm}$; Hole M0063E below microbiology sample

Depths: Hole M0063A $=48.37-52.87$ mbsf; Hole M0063C $=48.62-51.65$ mbsf; Hole M0063D = 48.84-53.40 mbsf

Recalculated depths if recovery is $>100 \%$ : Hole M0063A $=48.08-52.84$ mbsf; Hole M0063C = 47.80-51.15 mbsf; Hole M0063D = 47.97-53.13 mbsf

Unit $\mathrm{V}$ is dark gray to grayish brown very well sorted clay (Fig. F2). The internal structures show in part a massive appearance, but contorted silt laminated intervals are visible with clear convolute bedding. A smear slide (see "Core descriptions"), possibly from the silt laminae, shows $90 \%$ silt consisting of mainly quartz and feldspar, with iron oxide coatings on sand grains, green amphibole, glaucophane, and possible altered volcanic glass with stretched vesicles.

The laminated clay indicates a possible glaciolacustrine depositional environment, whereas the convolute bedding shows that the Unit $\mathrm{V}$ clay deposits may have been remobilized in a slump event. As in Subunit IIIa, the existence of volcanic glass may be related to volcanic ash spreading events.

\section{Unit VI}

Intervals: $347-\mathrm{M} 0063 \mathrm{~A}-18 \mathrm{H}-1,37 \mathrm{~cm}$, to $30 \mathrm{H}-1$, $134 \mathrm{~cm}$; 347-M0063C-26H-2, $15 \mathrm{~cm}$, to $39 \mathrm{H}-1$, $136 \mathrm{~cm} ; 347-\mathrm{M} 0063 \mathrm{D}-28 \mathrm{H}-1,90 \mathrm{~cm}$, to end of hole; Hole M0063E below microbiology sample to $347-\mathrm{M} 0063 \mathrm{E}-44 \mathrm{H}-1,16 \mathrm{~cm}$

Depths: Hole M0063A = 52.87-93.44 mbsf; Hole M0063C $=51.65-92.16$ mbsf; Hole M0063D = 53.40-86.8 mbsf

Recalculated depths if recovery is $>100 \%$ : Hole M0063A = 52.84-93.44 mbsf; Hole M0063C = 51.15-92.16 mbsf; Hole M0063D = 53.13-87.06 mbsf

Unit VI is the thickest unit at Site M0063. At more than $40 \mathrm{~m}$ thick, this unit shows significant development from the uppermost part where the unit is represented by dark gray-brown clay in millimeter- to centimeter-scale, interlaminated by millimeter-scale silt laminae (Fig. F2). With depth, several distinct varved fining-upward couplets are present, as well as sand laminae and pockets in millimeter scale.

From the top of this unit to around $75 \mathrm{mbsf}$, scattered centimeter-scale carbonate concretions are identified within silt millimeter-scale laminae. The common shape of the concretions is elliptical (Fig. F3), and they are often found associated with a drop- stone nucleus; multiple smaller concretions are observed on a larger dropstone.

From $\sim 85$ mbsf, brown and weak red are the dominating colors and clay-silt-sand interlaminations are present in thicker units. Clay laminae $2-20 \mathrm{~cm}$ thick, occasionally with internal slumping and silt laminae on the millimeter scale, bundled to centimeter scale, are also common. In the lowermost part of Unit VI, well-sorted sand laminae and dispersed clasts occur. The lower boundary is gradational. Microscale transverse faults displace the laminated clay at the centimeter scale (Fig. F4).

Smear slides (see "Core descriptions") of clay and silty clay laminae show iron oxide coatings on quartz, light green amphibole, and possibly altered volcanic glass with stretched vesicles. Sand quartz grains are angular to subangular, and green amphibole is common.

The rhythmically banded clays with varved internal grading are indicative of lake deposits, and the increased grain size and frequency of sand laminations in the lower sections, as well as subangular sand and centimeter-scale pebble grains, point to a glaciolacustrine environment. The upper part shows ice-distal facies types, whereas the lower ice-rafted part is deposited in an ice-proximal setting. As in Subunit IIIa and Unit V, the presence of altered volcanic glass in smear slides may be indicative of deposition of volcanic ash.

\section{Unit VII}

Intervals: 347-M0063A-30H-1, $134 \mathrm{~cm}$, through $31 \mathrm{H}-2$; 347-M0063C-39H-1, $136 \mathrm{~cm}$, to 39H-CC, $22 \mathrm{~cm}$; 347-M0063E-44H-1, $16 \mathrm{~cm}$, to end of hole

Depths: Hole M0063A = 93.44-95.8 mbsf; Hole M0063C $=92.16-93.30$ mbsf; Hole M0063E = 91.96-92.80 mbsf

The lowermost part of the core penetrates a brown, clast poor, sandy diamicton (Fig. F2) with a clast percentage of $\sim 10 \%$ and a general pebble size of $0.2-0.5$ $\mathrm{cm}$. The maximum clast size is $4 \mathrm{~cm}$. It is poorly sorted sediment, and the clasts are angular to subangular and faceted, consisting of rock clasts of quartz crystalline basement, Palaeozoic limestone, and sandstone. The poorly sorted sediment is also visible in smear slide samples (see "Core descriptions") with high contents of clay, silt, and sand. Birefringent coatings on sand grains are common, and iron oxide coatings are also observed; sand grain shapes are angular-subangular.

The diamicton of Unit VII can be interpreted as the result of mass-transport processes like massive debris 
flows or as a till with high content of locally eroded lithologies.

\section{Biostratigraphy Diatoms}

Holes M0063A, M0063C, and M0063E were qualitatively analyzed for siliceous microfossils. In Hole M0063A, every section top was analyzed through Core 347-M0063A-18H (54 mbsf), and deeper than this level, every core top was analyzed (Fig. F5; Table T2). To locate the brackish phase of the Yoldia Sea stage of Baltic Sea history (with a duration of only 150 y; Andrén et al., 2002), cores from Hole M0063C were sampled between 42 and $45 \mathrm{mbsf}$ at $20 \mathrm{~cm}$ resolution (Table T3). In addition, 15 samples from Cores 347-M0063E-13H through 22H ( 24-42 mbsf) were analyzed to cover the transition from the brackish Yoldia Sea stage to the Littorina Sea stage (Fig. F6; Table T4). All 93 diatom taxa found at Site M0063 were identified to species level (Table T5), with the exception of Chaetoceros vegetative cells and resting spores, which were recorded if present. Chrysophyte cysts were divided into different morphotypes based on the morphology of their silica cell walls.

The results of the qualitative diatom analyses in Holes M0063A and M0063E are summarized in graphs showing the number of taxa found divided into different salinity affinities and life forms (planktonic, periphytic, and sea ice) (Figs. F5, F6). Diatoms were classified with respect to salinity tolerance according to the Baltic Sea intercalibration guides of Snoeijs et al. (1993-1998), which divide taxa into five groups: marine, brackish-marine, brackish, brackish-freshwater, and freshwater. Furthermore, if present, other siliceous microfossils found (silicoflagellates, ebridians, and chrysophyte cysts) are shown in Figures F5 and F6.

\section{0-25.5 mbsf}

The preservation of diatoms is considered good to very good in this section based on the presence of delicate vegetative frustules of Chaetoceros in high abundance, which is in accordance with a previous study from the area (Thulin et al., 1992). This section records a brackish-marine assemblage typical of the recent Baltic Sea and inclusive of the most marine phase of the Littorina Sea stage of Baltic Sea history (Thulin et al., 1992; Westman and Sohlenius, 1999; Andrén et al., 2000a). The section contains intervals with taxa indicating colder and warmer periods, and a more developed paleoecological/paleoclimatological division will follow when proper counts are accomplished.
The diatom assemblage is of medium diversity, and a few planktonic taxa dominate, such as the marine Pseudosolenia calcar-avis, brackish-marine Thalassionema nitzschioides, and genus Chaetoceros (both resting spores and vegetative cells). $P$. calcar-avis is a common marine warm-water species that also occurs seasonally in both oceanic and near-shore temperate waters (Hasle and Syvertsen, 1996; Sundström, 1986). This species is common in sediments deposited during the Littorina and post-Littorina Sea stages (Andrén et al., 2000a) and also at Site M0063, but it is not found in the present Baltic Sea (Snoeijs and Kasperoviciene, 1996).

Several brackish and brackish-freshwater plankton taxa such as Thalassiosira hyperborea var. lacunosa, Thalassiosira levanderi, and Thalassiosira baltica are abundant throughout the section together with the ice-associated Pauliella taeniata. A small number of other ice-associated taxa also occur, such as Fragilariopsis cylindrus and a few records of Melosira arctica and Nitzschia frigida. T. hyperborea is a pelagic coolwater taxon with four varieties classified according to geographical distribution (two in the Baltic Sea and two in the Arctic Ocean) and morphology (Hasle and Lange, 1989). The Baltic species we find in our samples, T. hyperborea var. lacunosa, may be the resting spore of the delicate variety more rarely found in sediment (Hasle and Lange, 1989). T. hyperborea, T. baltica, P. taeniata, F. cylindrus, M. arctica, and $N$. frigida have been found in samples of melted ice from the northern Baltic Sea (Huttunen and Niemi, 1986) and may be considered as "sea ice algae" (Hasle and Syvertsen, 1990).

In the most marine phase of the Littorina Sea stage, when surface water salinity was $\sim 12-13$ in the Baltic Proper compared to the present range of 6-8 (Widerlund and Andersson, 2011), the resting spores of $C$. mitra and T. nitzschioides have been used as marine influence indicators (Westman and Sohlenius, 1999; Andrén et al., 2000a, 2000b). Chaetoceros mitra is a common diatom in the North Sea but does not occur in the present Baltic Sea because of low salinity (Hasle and Syvertsen, 1990). The most marine phase of this section is recorded between $\sim 15$ and 24 mbsf. It is manifested by the presence of the silicoflagellate Dictyocha speculum, the diatom taxa T. nitzschioides, and C. mitra resting spores (Fig. F5).

The ebridian Ebria tripartita is recorded at most levels, and chrysophyte cysts show a diverse assemblage with various morphotypes throughout the section.

\section{5-27 mbsf}

In Holes M0063A and M0063E, this interval records a consistent transition from a freshwater assemblage below to the overlying brackish-marine assemblage. 
This transition, with slightly brackish conditions, is usually referred to as the initial Littorina Sea stage in the Baltic Proper (e.g., Andrén et al., 2000a, 2000b) or the Mastogloia Sea in the Baltic coastal zone (e.g., Sundelin, 1922; Hedenström and Risberg, 1999). The transition reflects increased influence of brackish water and is visible in the diatom assemblage as a shift from dominance of freshwater taxa to dominance of brackish-marine taxa. Taxa assigned to brackishfreshwater affinity are found in high numbers during this transition (Figs. F5, F6).

Chrysophytes are recorded at most levels but are not as diverse as in the uppermost brackish-marine section (0-25.5 mbsf). E. tripartita is occasionally recorded.

\section{7-41 mbsf}

The lower part of this interval starts with a long sequence of barren samples or samples with very low number of taxa (Figs. F5, F6). The uppermost samples in Holes M0063A and M0063E show a simultaneous increase in a number of taxa that indicate large lake conditions (i.e., Aulacoseira islandica, Aulacoseira subarctica, and Stephanodiscus neoastraea). This section most probably indicates the conditions of the final freshwater phase of the Yoldia Sea stage and the Ancylus Lake. These two stages are not easily distinguished in the diatom stratigraphy in the open Baltic Basin because there is no change in salinity. A slight increase in transported periphytic taxa, due to the Ancylus transgression (Andrén et al., 2011), marks the onset of the Ancylus Lake in the Eastern Gotland Basin (Andrén et al., 2000a). The barren sequence of this section corresponds to a sediment core recovered from a shallower site in the Landsort Deep (Lepland et al., 1999) and cores from the Eastern Gotland Basin (Sohlenius et al., 1996; Andrén et al., 2000a).

Chrysophytes are recorded occasionally in this section, most commonly as a morphotype with smooth cell walls.

\section{1-43 mbsf}

In all analyzed holes (M0063A, M0063C, and M0063E) the brackish phase of the Yoldia Sea stage of Baltic Sea history was detected using diatom stratigraphy combined with its stratigraphic position. A diatom assemblage typical of the Yoldia Sea stage was found at one level in Hole M0063A, five levels in Hole M0063C, and two levels in Hole M0063E. All samples were located within $1 \mathrm{~m}$ interval in the core (Figs. F5, F6). The Yoldia Sea stage assemblage in this section has a low diversity but a high abundance, especially of the brackish-freshwater taxa Thalassiosira baltica, which indicates slightly brackish conditions.
T. baltica has previously been recorded in this stage and tends to more or less entirely dominate the assemblage (Lepland et al., 1999; Andrén et al., 2000a). Chrysophytes are recorded in this section.

\section{3-102 mbsf}

The lowermost analyzed section of Hole M0063A was mostly devoid of siliceous microfossils (Fig. F5).

\section{Foraminifers}

These results summarize the data on samples taken offshore and onshore (i.e., samples taken from core catchers and regular sections). A total of 194 samples were processed and analyzed from Holes M0063A, M0063B, M0063C, M0063D, and M0063E for the presence of foraminifers (Table T6).

Previous records of foraminifers from the central Baltic Basin are rare. A recent record used the abundance of Elphidium excavatum to indicate when inflows of higher salinity water occurred into the Eastern Gotland Basin, suggesting strong variations for the last millennium (Kotilainen et al., 2014). Wastegård et al. (1995) similarly used the presence of E. excavatum to link more saline/brackish conditions to the Yoldia Sea stage of Baltic Sea history in a core retrieved just north of the Landsort Deep.

Foraminifers at Site M0063 occur continuously from the sediment surface to $\sim 30$ mbsf (Section 347M0063B-14H-CC), with maximum abundances in the upper 20 mbsf (few to abundant). Between 20 and $30 \mathrm{mbsf}$, abundance decreases from few to very rare (Fig. F7). The taxonomic diversity is low, mainly based on analysis of the upper samples ( $0-7 \mathrm{mbsf})$, as preservation is poor deeper than this interval, and identification was often only possible to the genus level. In addition to signs of dissolution, many specimens are covered by what may either be organic material or inorganic precipitate coating. The fauna mainly consists of Elphidium spp., with Elphidium excavatum f. clavata and Elphidium excavatum f. selseyensis dominating. Elphidium albiumbilicatum and possibly Haynesina spp. are the minor components of the fauna. The close similarity of the different Elphidium spp., the occurrence of ecophenotypes, and the increasingly poor preservation downcore make it impossible at this stage to determine any clear variations in their relative distribution (Schweizer et al., 2008; Pillet et al., 2013).

It has been suggested that during the late-middle Holocene, salinity in the Baltic Proper was higher than modern bottom water values $(\sim 10)$, potentially as high as 15-20 (e.g., Gustafsson and Westman, 2002). It is unlikely that values would have been higher, as this would likely have resulted in a more 
diverse foraminiferal assemblage, for example in the Eemian Peski section along the Gulf of Finland where Bucella frigida occurred when salinity became $>20$ (Miettinen et al., 2014). Between 20 and 30 mbsf, the contribution of E. albiumbilicatum increases, suggesting that conditions might have become slightly fresher.

The very rare occurrence of several E. excavatum and E. albiumbilicatum specimens at 45 mbsf (Section 347-M0063C-23H-2, $15 \mathrm{~cm}$ ) might be attributed to the Yoldia Sea stage (based on diatom results). The additional very rare occurrence in Section 347M0063A-22H-CC (45.48 mbsf) of Elphidium spp. cannot directly be linked to a specific stage and may not be significant.

\section{Ostracods}

A total of 225 samples (including 129 core catchers) from Holes M0063A, M0063B, M0063C, M0063D, and M0063E were examined for ostracods during the onshore phase of Expedition 347. Samples were studied in the $>125 \mu \mathrm{m}$ fraction. Ostracods were present in 25 samples (Table T7).

Ostracods were mainly found in Holes M0063B, M0063C, and M0063D and only in two samples in Hole M0063A. Abundance per sediment volume from the three holes (M0063B, M0063C, and M0063D) was very low and did not exceed 4 valves/ $20 \mathrm{~cm}^{3}$ sediment sample (Fig. F8). Seven taxa were identified: Sarsicytheridea bradii, Heterocyprideis sorbyana, Cytheropteron pseudomontrosiense, Paracyprideis sp., Palmoconcha spp., Leptocythere spp., and Candona sp.

Ostracods occur in low abundance in the upper $18 \mathrm{~m}$ (Holes M0063B-M0063D). Deeper than this interval, they were only recorded at $\sim 26$ and $\sim 39$ mbsf (Hole M0063D).

Preservation of ostracods is very poor, and valves often bear signs of dissolution. Similarly, preservation of foraminifers is generally moderate and worsens downcore (see "Foraminifers"). Low abundance and poor preservation prevent paleoenvironmental interpretation of the ostracod data.

Previous work suggests that dissolution of calcareous microfossils is one of the major taphonomic processes in the Baltic Sea. Benthic foraminiferal work shows major differences in the abundance and assemblages of living versus dead foraminifers (Murray and Alve, 1999). Ostracods are even more susceptible to dissolution, and their low abundance together with dissolution signs on both ostracods and foraminifers indicate postmortem changes (Swanson and van der Lingen, 1997).

\section{Palynological results}

Site M0063 is situated in the boreal-forest vegetation zone but close to the transition to cool temperate forest with mixed coniferous and deciduous trees that characterizes the terrestrial realm of the southeastern Baltic region. For this site, palynological analyses focused on Hole M0063A. Generally, one sample per core was examined for palynomorphs. Bisaccate pollen grains are included in the pollen reference sum, with average percentages of $\sim 50 \%$ of the total pollen assemblage.

From Hole M0063A, a total of 29 sediment samples were analyzed. Generally, sediments from the upper part contained palynomorphs in excellent preservation (Fig. F9; see PalyM0063.xls in PALYNOLOGY in "Supplementary material") and sufficient numbers to yield statistically relevant palynological results (Figs. F10, F11), whereas only a few samples deeper than 32.86 mbsf could be analyzed in detail.

\section{Core depth interval $\sim 0.06-19.70$ mbsf}

The uppermost interval contains pollen assemblages that reflect Holocene conditions. Several samples were palynologically analyzed for this interval. Counting sums vary around 100 pollen grains per pollen spectrum (Fig. F11) because of relatively high pollen concentrations between 20,000 and 130,000 grains $/ \mathrm{cm}^{3}$. The pollen spectra of this depth interval are dominated by Pinus sylvestris type (maximum = $62 \%$ ), Betula alba type (maximum $=28.5 \%$ ), Alnus glutinosa type (maximum $=17 \%$ ), and Quercus $(18.5 \%)$. Pollen of other deciduous trees like Fraxinus, Ulmus, Tilia cordata type, and Carpinus were noted. Percentage shares of Corylus avellana pollen vary between $1 \%$ and $10 \%$. In the uppermost sample, pollen grains of Secale type and Triticum type (Fig. F9, No. 1) were found, as well as a single occurrence of Fagus pollen (Fig. F9, No. 3).

The most striking feature of this interval is the presence of Picea pollen, with percentages increasing from $<1 \%$ at the bottom of the interval to $5 \%$ at the top. The increasing upward Juniperus pollen curve (from 5.5\% to 9.97\%) allows for correlating this pollen interval with radiocarbon dated sediments from Landsort Deep for $\sim 5630 \pm 75 \mathrm{C}^{14} \mathrm{y} \mathrm{BP}$ at the bottom and for $\sim 1605 \pm 100 \mathrm{C}^{14} \mathrm{y}$ BP at the top (Thulin et al., 1992). Comparison of our pollen diagram with dated sediments from Lake Judesjön in northern Sweden suggests an age of the bottom interval of $\sim 3600 \mathrm{y}$ BP (Wallin, 1996).

Radiosperma (Fig. F9, No. 8) and Thecamoeba remains (Fig. F9, No. 9) are frequent in most samples from this interval, and freshwater algae occur in several samples. Dinoflagellate cysts also occur in sev- 
eral samples. A particularly high dinocyst/pollen ratio was encountered in two samples at 16.95 and 19.70 mbsf, but the dinocyst assemblages are almost monospecific, with Operculodinium/Protoceratium reticulatum showing percentages of $\sim 75 \%$. Most specimens are characterized by short processes. The two samples with a relatively high dinocyst/pollen ratio also contain Copepod eggs.

\subsection{5-39.45 mbsf}

Several samples examined from this interval are barren of palynomorphs or show low pollen concentrations $\left(\sim 10,000\right.$ or less pollen grains $\left./ \mathrm{cm}^{3}\right)$. Three pollen spectra were achieved in this interval. Pinus sylvestris type pollen prevail in all of them and fall from $55 \%$ at the bottom of the interval to $40 \%$ at the upper sample. The percentages of Betula alba type pollen are significantly lower compared to the overlying interval and increase from $9.5 \%$ at the bottom to $17 \%$ at the top. Quercus and Corylus avellana achieve the highest shares in the entire pollen succession: $19.5 \%$ and $11.5 \%$, respectively. Together with Ulmus pollen $(4.5 \%)$, these percentages may point to a late-middle Holocene age for this interval (Antonsson et al., 2006).

\subsection{0 mbsf}

Only one pollen spectrum was achieved in this part of the core. It is dominated by Pinus sylvestris type $(47.50 \%)$ and Betula alba type (26.50\%) pollen. Picea pollen is 3.5\%. Pollen of deciduous trees like Quercus, Alnus glutinosa type, Fraxinus, Carpinus, and Corylus avellana were present in amounts exceeding $1 \%$. It is very difficult to attribute even roughly the possible age of this spectrum. The presence of thermophilous tree taxa and Picea pollen suggests contamination from the upper part of the sediments. On the other hand, in a pollen succession from Lake Gilltjärnen, northern central Sweden (Antonsson et al. 2006), similar pollen spectra were recorded around 10,500$11,000 \mathrm{cal}$ y BP. The lack of Picea pollen in the spectra from this lake may be explained with eastern migration of spruce into Sweden.

\section{$66.18 \mathrm{mbsf}$}

The only pollen spectrum in this part of Hole M0063A is overwhelmingly dominated by Pinus sylvestris type pollen (77\%), whereas Betula alba pollen are $7 \%$. Relatively high values (the highest in the entire pollen succession from Hole M0063A) are achieved by Chenopodiaceae (6\%) and Artemisia (3.5\%) pollen. The presence of these pollen types points to open steppe-like communities. It may imply a pre-Holocene age for this spectrum. Late glacial interstadials Bølling/Allerød cannot be ruled out.
Again, there is also the possibility of contamination (see "Lithostratigraphy"). In this sample, Thecamoeba remains could also be found.

\subsection{0-101.94 mbsf}

Pollen concentration in the 10 samples analyzed for this interval varies between 0 and 1000 grains $/ \mathrm{cm}^{3}$; therefore, it was not possible to gain statistically relevant data for these samples. As a consequence, this interval is not depicted in the detailed pollen diagram (Fig. F10).

\section{Geochemistry Interstitial water}

Variations in pore water geochemistry at Site M0063 reflect the transition from Holocene brackish marine deposits in the upper 27 mbsf of the core (Unit I) to the underlying glaciolacustrine sediments (Units IIVII) (see "Lithostratigraphy" and "Biostratigraphy"), microbial degradation of organic matter concentrated in the marine sediments, and mineral reactions that may include dissolution and ion exchange.

\section{Salinity variations: chloride, salinity, and alkalinity}

Pore water chloride $\left(\mathrm{Cl}^{-}\right)$concentrations are $\sim 170$ $\mathrm{mM}$ in the uppermost samples at $1.3 \mathrm{mbsf}$, increase to $190 \mathrm{mM}$ at $9-14 \mathrm{mbsf}$, decrease to $<20 \mathrm{mM}$ at $\sim 50$ mbsf, and continue to decline for the remainder of the profile (Fig. F12A; Table T8). Similar trends are observed in salinity, which from a maximum of $\sim 15$ at $\sim 8$ mbsf decreases to $<2$ at $\sim 50$ mbsf (Fig. F12B). Peak values for $\mathrm{Cl}^{-}$based salinity are slightly lower (by $\sim 2$ ) than shipboard salinity measured by refractometer (Fig. F12B; Tables T8, T9). As at Site M0059, this difference can be explained when considering that additional ions related to organic matter degradation may contribute to salinity. Although peak pore water alkalinity concentrations of $\sim 55 \mathrm{meq} / \mathrm{L}$ at Site M0063 (Fig. F12C) are a factor of 4 lower than those observed at Site $\mathrm{M0059}, \mathrm{Cl}^{-}$based salinity can be corrected to match shipboard salinity by assuming that $\mathrm{HCO}_{3}{ }^{-}$is the primary anion contributing to salinity and calculating anion-based salinity (Fig. F12D). Results imply that $\mathrm{HCO}_{3}{ }^{-}$is amplifying pore water salinity in the upper $\sim 35 \mathrm{~m}$ of the profile but with less influence than that observed at Site M0059. Thus, $\mathrm{Cl}^{-}$based salinity is a better estimate of bottom water salinity at Site M0063. It suggests a past period with higher bottom water salinity than today. Scattered salinity and $\mathrm{Cl}^{-}$values in Hole M0063E, particularly between 48 and 70 mbsf, may indicate con- 
tamination from seawater (Table T8). Therefore, salinity and $\mathrm{Cl}^{-}$data from Hole M0063E are listed in Tables T8 and T9 but are not included in subsequent plots.

\section{Organic matter degradation: methane, sulfate, sulfide, ammonium, phosphate, iron, manganese, $\mathrm{pH}$, bromide, and boron}

Measurements of methane $\left(\mathrm{CH}_{4}\right)$ concentrations were only done for Hole M0063A (Fig. F13A; Table T10). There was extensive degassing of $\mathrm{CH}_{4}$ prior to collection, and therefore the $\mathrm{CH}_{4}$ profile should be viewed as an indicator of presence or absence rather than interpreted as absolute values. Methane is present at all depths to $\sim 74 \mathrm{mbsf}$. Deeper than this depth, there is a consistent and distinct increase in sulfate $\left(\mathrm{SO}_{4}{ }^{2-}\right)$ concentrations to $1.8 \mathrm{mM}$ at $\sim 102$ mbsf, coinciding with the absence of methane (Fig. F13B). Though the source of $\mathrm{SO}_{4}{ }^{2-}$ is uncertain, this pattern may suggest that $\mathrm{SO}_{4}{ }^{2-}$ is the dominant electron acceptor at depth (Lovley and Phillips, 1987). Sulfate concentrations in all holes are generally $<0.01 \mathrm{mM}$ in the upper $74 \mathrm{~m}$, but there is scatter in some parts of the profile. This scatter is particularly but not exclusively noted in Hole M0063E, suggesting the potential for contamination by seawater. Pore water $\mathrm{H}_{2} \mathrm{~S}$ was analyzed throughout Hole M0063A and also in one sample from the uppermost part of Holes M0063B and M0063D, with all samples below or at the detection limit. Traces of $\mathrm{H}_{2} \mathrm{~S}$ with values of $0.001 \mathrm{mM}$ were only detected at $\sim 1.4 \mathrm{mbsf}$ in Hole M0063B.

The profiles for ammonium $\left(\mathrm{NH}_{4}^{+}\right)$and phosphate $\left(\mathrm{PO}_{4}{ }^{3-}\right)$ (Fig. F13D-F13E) are similar to the alkalinity profile, suggesting production of these solutes is due to organic matter mineralization. There is considerable scatter in the upper 30 mbsf of the $\mathrm{PO}_{4}{ }^{3-}$ profile for all holes, but a clear trend is still apparent. As with alkalinity, the maxima in $\mathrm{PO}_{4}{ }^{3-}(1.5 \mathrm{mM})$ and $\mathrm{NH}_{4}{ }^{+}(10 \mathrm{mM})$ concentrations are centered in the upper 15-20 mbsf, but compared to Site M0059, they are lower by factors of 2 and 4, respectively.

Dissolved iron $\left(\mathrm{Fe}^{2+}\right)$ shows peak concentrations of $\sim 230 \mu \mathrm{M}$ in the uppermost samples at around 1.5 mbsf and decrease sharply to $\sim 2.5 \mu \mathrm{M}$ by 5 mbsf (Fig. F13F). A minor peak of $\sim 75 \mu \mathrm{M}$ is observed by 16 mbsf above a decline back to values of $\sim 10 \mu \mathrm{M}$ by 24 mbsf. Further downcore, concentrations of dissolved iron increase substantially to result in a maximum of $560 \mu \mathrm{M}$ at $\sim 35 \mathrm{mbsf}$ before a sharp decline to near 10 $\mu \mathrm{M}$ by $\sim 50$ mbsf. There is some variation in the magnitude of the latter dissolved $\mathrm{Fe}^{2+}$ peak between holes, but the maximum is distinct in all holes.
Deeper than 50 mbsf, in the glaciolacustrine sediments, $\mathrm{Fe}^{2+}$ concentrations in all holes slowly decline and are below detection by $65 \mathrm{mbsf}$ and through the rest of the profile.

Generally, the $\mathrm{Mn}^{2+}$ profile resembles that of Site M0059, with a trend of rapidly declining pore water concentrations in the upper few meters followed by a more gradual decline starting at 15 mbsf. However, near-surface concentrations of $1200 \mu \mathrm{M}$ in the uppermost samples (1.5 mbsf) at Site M0063 are twice those observed at Site M0059 (Fig. F13G). Similar to $\mathrm{Fe}^{2+}, \mathrm{Mn}^{2+}$ shows a local minimum around 3-5 mbsf, followed by a broader peak of $\sim 300 \mu \mathrm{M}$ by $\sim 12 \mathrm{mbsf}$, and then a decline to $3 \mu \mathrm{M}$ by the bottom of the profile at 102 mbsf.

$\mathrm{pH}$ varies between holes by as much as 0.5 in some portions of the profile, but an overall trend is still apparent (Fig. F13H). In general, $\mathrm{pH}$ increases from 7.7 at the top to peak above 8 at 10 mbsf. Deeper than this depth, $\mathrm{pH}$ decreases, with a minimum of $\sim 7.5$ at 35 mbsf, and then gradually increases to yield a second peak of $\sim 8.5$ in the lower part of the profile.

Pore water bromide $\left(\mathrm{Br}^{-}\right)$and boron (B) profiles resemble those of salinity (Fig. F14A, F14C). Ratios of these elements to $\mathrm{Cl}^{-}$are similar to those for seawater to at least 50 mbsf (Fig. F14B, F14D). Deeper than this depth, increasing and scattered element to $\mathrm{Cl}^{-}$ ratios likely result from very low $\mathrm{Cl}^{-}$concentrations measured in the deeper core sections.

\section{Mineral reactions}

Sodium, potassium, magnesium, calcium, silica, lithium, barium, and strontium

Pore water sodium $\left(\mathrm{Na}^{+}\right)$, potassium $\left(\mathrm{K}^{+}\right)$, and magnesium $\left(\mathrm{Mg}^{2+}\right)$ display trends similar to salinity with a broad peak in the upper portion of the profile followed by a gradual decline in concentrations to very low values around 50 mbsf (Fig. F15A-F15C). Calcium concentrations display two distinct peaks in the upper $50 \mathrm{~m}$ : a muted peak of $\sim 5 \mathrm{mM}$ in the upper $20 \mathrm{~m}$ and a larger peak of $10 \mathrm{mM}$ at $\sim 40$ mbsf (Fig. F15D). Deeper concentrations gradually decline to values $<1 \mathrm{mM}$. When normalized to $\mathrm{Cl}^{-}$, it appears that bottom water salinity is a major control on $\mathrm{Na}^{+}$, $\mathrm{K}^{+}, \mathrm{Mg}^{2+}$, and $\mathrm{Ca}^{2+}$ concentrations (Fig. F15E-F15H). Deviations in element to $\mathrm{Cl}^{-}$ratios from the assumed ratio of the primary bottom water indicate removal or addition to the pore waters through reactions or exchange with the sediment. However, concentrations of the individual elements $\mathrm{Na}^{+}, \mathrm{Mg}^{2+}, \mathrm{K}^{+}, \mathrm{Ca}^{2+}$, and $\mathrm{Cl}^{-}$each become particularly low deeper than 70 mbsf, meaning that subtle changes in the elemental values may be exaggerated in the ratios. However, 
the increases in $\mathrm{Ca} / \mathrm{Cl}$ starting near 25 mbsf and in $\mathrm{Mg} / \mathrm{Cl}$ starting near $35 \mathrm{mbsf}$ are more gradual and well defined than the scattered ratios deeper.

The trend for strontium $\left(\mathrm{Sr}^{2+}\right)$ and lithium $\left(\mathrm{Li}^{+}\right)$resembles that of alkalinity with a peak centered within the upper 15-20 mbsf followed by a gradual decrease in concentration toward the basal parts of the profile (Fig. F16A-F16B). There is scatter in the upper $40 \mathrm{~m}$ of the dissolved silica $\left(\mathrm{H}_{4} \mathrm{SiO}_{4}\right)$ profile (Fig. F16C), but an overall trend of gradually decreasing values is observed for all holes. Silica input into pore fluids may be attributed to diatom dissolution or weathering of silicates. As at Site M0059, the shape of the barium $\left(\mathrm{Ba}^{2+}\right)$ profile (Fig. F16D) most closely resembles that of $\mathrm{Ca}^{2+}$.

\section{Molybdenum, vanadium, and zirconium}

Pore water trace element concentrations of molybdenum (Mo), vanadium (V), and zirconium ( $\mathrm{Zr}$ ) (Table T8) reveal trends that are noteworthy yet less well defined than the elemental profiles discussed above. Mo data reveal scatter in all holes in the upper $~ 30$ mbsf with values ranging from below detection to $5.7 \mu \mathrm{M}$ but without any observable trend. Deeper than $\sim 30$ mbsf, there is a consistent trend between holes with Mo concentrations steadily increasing to values of $\sim 0.43 \mu \mathrm{M}$ ( $\sim 4$ times that of typical seawater). Vanadium concentrations display two peaks, the first centered between 2 and 5 mbsf and the second centered between 15 and 25 mbsf. Overall, there is a general trend of $\mathrm{V}$ concentrations decreasing downcore to values below detection at the bottom. Zirconium concentrations display a single spike centered between 15 and $25 \mathrm{mbsf}$, similar to the depths of the larger $\mathrm{V}$ peak, and a general trend to increasing concentrations of $\sim 110 \mathrm{nM}$ (3 orders of magnitude above typical seawater) at the bottom of the section.

\section{Sediment}

\section{Carbon content}

Sedimentary total carbon (TC) values varied from 2$10 \mathrm{wt} \%$ in the brackish marine deposit to $\sim 30 \mathrm{mbsf}$ and steeply dropped to $<1 \mathrm{wt} \%$ in the glaciolacustrine sediments deeper (Fig. F17A; Table T11). Most of the TC was present in its organic form with total organic carbon (TOC) values maximizing at $5 \mathrm{mbsf}$ $(\sim 7 \mathrm{wt} \%)$ and $20 \mathrm{mbsf}(\sim 9 \mathrm{wt} \%)$. The underlying clays were on the contrary lean in TOC, with values typically not exceeding $0.5 \mathrm{wt} \%$ (Fig. F17B). Total inorganic carbon (TIC) also peaked at 5 and 20 mbsf and was low ( 0.1 wt\%) throughout the rest of the sediment column (Fig. F17C).

\section{Sulfur content}

Total sulfur (TS) concentrations were generally high in the brackish marine deposit, with peaks of 3-4 $\mathrm{wt} \%$ at 5 and $20 \mathrm{mbsf}$ and was only low $(<0.1 \mathrm{wt} \%)$ in the organic-poor clay starting around $27 \mathrm{mbsf}$ (Fig. F17D). This trend reflects the different salinity stages transitioning from a freshwater to a marine environment with increasing sulfate concentrations.

\section{Physical properties}

This section summarizes the preliminary physical property results from Site M0063 in Landsort Deep, the deepest basin in the Baltic Sea (437.1 meters below sea level). Five holes were drilled at this site. Hole M0063A was drilled to 115.81 mbsf, Hole M0063B to $29.00 \mathrm{mbsf}$, Hole M0063C to $96.4 \mathrm{mbsf}$, Hole M0063D to 86.80 mbsf, and Hole M0063E to 92.80 mbsf. Hole M0063E was designated as a microbiology hole and was extensively subsampled onboard (see "Microbiology"). Strong expansion and methane gas release were encountered at Site M0063, resulting in disturbed core sections (with frequent gas bubbles and cracks) and loss of core material upon removal of the piston for Hole M0063A. Following this, the coring procedure was altered (see "Operations") to increase recovery. Within the uppermost $\sim 55$ mbsf of subsequent holes, recovery is in excess of $100 \%$.

Our interpretations are focused on the physical property data from Hole M0063C, which has the greatest continuous penetration (Fig. F18). Although all physical property measurements described in "Physical properties" in the "Methods" chapter (Andrén et al., 2015) were conducted at Site M0063, wholeround core shipboard $P$-wave data appear to be highly affected by artifacts. Thermal conductivity data are too sparsely distributed to exhibit any discernible downcore trend. Color reflectance variations do not correspond to other physical properties and lithostratigraphic units.

\section{Natural gamma radiation}

High-resolution natural gamma ray (NGR) values are relatively low ( $\sim 8 \mathrm{cps})$ in the upper interval of lithostratigraphic Subunits $\mathrm{Ia}$ and $\mathrm{Ib}$ and then drop to near zero at the Subunit Ib/Ic boundary (Fig. F18). NGR exhibits increasing values toward the base of lithostratigraphic Subunit Ic ( 10 cps), with a shift to lower values at the Subunit Ic/Id boundary. NGR progressively decreases in lithostratigraphic Subunit Id to $<5$ cps. These generally low NGR values within lithostratigraphic Unit I are interpreted as a result of high water content coupled with relatively high or- 
ganic and low clay content (see "Lithostratigraphy"). NGR values increase sharply below the upper boundary of lithostratigraphic Subunit IIa (>10 cps) and remain high in Subunit IIb (>15 cps). This change could be related to a decrease in water content within lithostratigraphic Unit II. NGR values are relatively constant in lithostratigraphic Unit III (including Subunits IIIa and IIIb), with several negative excursions that might reflect increased silty sand content. NGR values increase within lithostratigraphic Unit IV and remain high (>20 cps) and relatively constant through lithostratigraphic Units V, VI, and VII. Meter-scale peaks throughout Unit VI are likely to correspond to intervals of reduced grain size.

\section{Magnetic susceptibility and noncontact resistivity}

The greater water depth at Site M0063 required the use of additional sections of drill string that had not been previously deployed during Expedition 347 (see "Operations"). Rust derived from these sections contaminated the first section of each core run to 75 mbsf, which is apparent in the raw magnetic susceptibility data (see also "Stratigraphic correlation") but not in any other physical properties including noncontact resistivity (NCR). Contaminated intervals were identified by high-amplitude, abrupt spikes in magnetic susceptibility and were removed. Both magnetic susceptibility and NCR exhibit an increasing downhole trend and generally low values throughout lithostratigraphic Unit I (Fig. F18). The Unit I/II boundary is characterized by a small peak in magnetic susceptibility and a relative excursion in NCR. Meter-scale peaks in resistivity occur throughout lithostratigraphic Units III, IV, V, and VI. Large excursions in magnetic susceptibility are limited to the lower portion of lithostratigraphic Unit VI.

\section{Density}

Dry density increases downhole and is lowest in lithostratigraphic Unit I, with a minimum value of $0.28 \mathrm{~g} / \mathrm{cm}^{3}$ recorded in Subunit Ib (Fig. F18). Dry density increases below the Unit I/II boundary to $\sim 0.8 \mathrm{~g} / \mathrm{cm}^{3}$. Two excursions in dry density of $\sim 1.5 \mathrm{~g} /$ $\mathrm{cm}^{3}$ occur in lithostratigraphic Unit III. Through lithostratigraphic Unit VI, density is generally $>1 \mathrm{~g} /$ $\mathrm{cm}^{3}$. The greatest density $\left(1.68 \mathrm{~g} / \mathrm{cm}^{3}\right)$ in Hole M0063C occurs in lithostratigraphic Unit VII.

Discrete bulk density measurements are well correlated $\left(r^{2}=0.83\right)$ with high-resolution $(2 \mathrm{~cm}$ interval) gamma density measured during the offshore phase of Expedition 347 (Figs. F19, F20).

\section{$P$-wave velocity}

Discrete $P$-wave velocities in the upper $\sim 50 \mathrm{mbsf}$ (Units I-V) are typically $\sim 1250 \mathrm{~m} / \mathrm{s}$ (Fig. F19). Shipboard multisensor core logger (MSCL) measured velocities are anomalously low, likely due to poor core quality. At the bottom of lithostratigraphic Subunit $\mathrm{IVb}$, velocity as measured in discrete measurements increases to $\sim 1500 \mathrm{~m} / \mathrm{s}$ and the correspondence to the shipboard data generally improves.

\section{Paleomagnetism}

Magnetic susceptibility measurements and simplified analyses of the natural remanent magnetization (NRM) were made on discrete specimens of known volume and mass (see "Paleomagnetism" in the "Methods" chapter [Andrén et al., 2015]). A total of 216 discrete samples were taken from Hole M0063D at intervals of $\sim 50 \mathrm{~cm}$. The magnetic properties of the sample population were found to be extremely variable. Magnetic susceptibility $(\chi)$ gradually decreases from values of $1 \times 10^{-6} \mathrm{~m}^{3} / \mathrm{kg}$ in the lowermost Unit VII to $<0.1 \times 10^{-6} \mathrm{~m}^{3} / \mathrm{kg}$ in Units I and II. The intensity of the NRM varied over 3 orders of magnitude, from a maximum of $2.6 \mathrm{~A} / \mathrm{m}$ at a 55 mbsf in Unit VI to $0.3 \times 10^{-3} \mathrm{~A} / \mathrm{m}$ in Unit I, but with considerable variation in Units III, II, and I, with enhanced NRM intensities associated with laminated subunits.

Paleomagnetic pilot samples were grouped into four categories according to their response to alternating field (AF) demagnetization. Category 1 contains samples from Units VII, VI, and V (mostly laminated clays), has shallow inclination, and contains one or more carriers of NRM with medium to high coercivity. Category 2, associated with Units IV and III, also has medium to higher coercivity carriers of the NRM but steeper inclinations than Category 1. Category 3, which is characteristic of some samples from Units III, II, and I, has distinctly low NRM intensity and acquires a gyroremanent magnetization (GRM) at AF > $50 \mathrm{mT}$. Category 4 contains pilot samples from Units II and I, and it is distinguished from the other categories by a demagnetization curve that indicates a narrow magnetic grain size distribution. This fourth category includes samples with steep inclinations and high NRM intensity. An important observation is that the discrete paleomagnetic samples taken from the upper $0.75 \mathrm{~m}$ of cores were disturbed (see "Stratigraphic correlation") and have shallow and normal or reversed inclinations. It was therefore concluded that changes in inclinations and declination are highly dependent on magnetic mineralogy and identified coring disturbance. 


\section{Discrete sample measurements}

A total of 216 discrete paleomagnetic samples were obtained from Hole M0063D at $50 \mathrm{~cm}$ intervals.

\section{Magnetic susceptibility}

The results of the magnetic analyses are shown in Figure F21. Magnetic susceptibility $(\chi)$ ranges between $<0.1 \times 10^{-6}$ and $1 \times 10^{-6} \mathrm{~m}^{3} / \mathrm{kg}$, and a general declining trend in $\chi$ is evident from the bottom of Unit VII to the top of Unit I, which appears to be positively related to a decrease in sample wet density. The lowermost Unit VII (clayey silty sand) contains the highest $\chi$ values, close to $1 \times 10^{-6} \mathrm{~m}^{3} / \mathrm{kg}$, and the values decline through Units VI, V, and IV to reach a minimum of $\sim 0.2 \times 10^{-6} \mathrm{~m}^{3} / \mathrm{kg}$. Subunit Id has low $\chi$ values of $<0.1 \times 10^{-6} \mathrm{~m}^{3} / \mathrm{kg}$. There are several samples in Units III, II, and Ib that have significantly higher $\chi$ than the background level for these units, which is between $<0.1 \times 10^{-6}$ and $0.2 \times 10^{-6} \mathrm{~m}^{3} / \mathrm{kg}$.

\section{Natural remanent magnetization and its stability}

The intensity of the NRM displays a wide range over almost 4 orders of magnitude, suggesting a variable magnetic mineralogy and/or efficiency of recording of the geomagnetic field. The NRM intensity spans between $0.3 \times 10^{-3}$ and $2.6 \mathrm{~A} / \mathrm{m}$. The NRM intensity displays a consistent positive relationship with $\chi$ in Units VII and VI. In Units III, II, and I, this relationship is disturbed by the occurrences of samples with relatively high NRM intensity compared to $\chi$. Four categories of response to AF demagnetization were observed in the pilot samples (Fig. F22). The majority of pilot samples taken from Units VII, VI, and V, which contain laminated (varved) clays, display a linear orthogonal vector that trends toward the origin during AF demagnetization, and the carrier(s) of remanence have medium to high coercivity, with a residual NRM intensity of $\sim 15 \%$ after the treatment at $80 \mathrm{mT}$. This category (Category 1 ) has relatively low inclinations between $30^{\circ}$ and $40^{\circ}$. Category 2 samples also contain a medium- to high-coercivity carrier of the NRM, but the inclinations are close to the geocentric axial dipole (GAD) prediction for the site location $\left(73^{\circ}\right)$. Category 3 includes pilot samples with relatively low NRM intensity and low $\chi$ and they acquire a relatively strong GRM during AF demagnetization that causes the sample intensity to increase at $\mathrm{AF}>50 \mathrm{mT}$ and the vector to lie in the plane perpendicular to the last demagnetization axis (Snowball, 1997). The majority of the pilot samples obtained from Units II and I belong to Category 4, which is defined by a low- to medium-coercivity carrier of the NRM. The NRM is most effectively re- moved between a narrow range of AF steps (10-40 $\mathrm{mT}$ ), which indicates a narrow magnetic grain size distribution.

\section{Paleomagnetic directions}

Core sections recovered from Hole M0063D were often found to be disturbed by drilling and degassing in the upper $0.75 \mathrm{~m}$ of cores, which resulted in scattered inclination data. With the exceptions of Units IIIb and V, which contain disturbed and convoluted structures, the identification and removal of these data points improve the fidelity of the inclination record. However, the variable magnetic properties downhole and different categories of response to $\mathrm{AF}$ demagnetization, which includes samples that acquire GRM, probably preclude using the paleomagnetic data for relative dating purposes. The most notable observation is that the relatively strong NRM intensity in relation to $\chi$ is associated with Category 4 pilot samples, which are generally confined to the laminated Subunits Id and Ib. Similar magnetic enhancement of Baltic Sea sediments was reported by Reinholdsson et al. (2013) and was assigned to the preservation of greigite $\left(\mathrm{Fe}_{3} \mathrm{~S}_{4}\right)$ magnetofossils in laminated sapropels that formed during periods of basin-wide hypoxia due to natural and anthropogenically induced increases in Baltic Sea primary production (e.g., Zillen et al., 2008).

Our main conclusion is that the variable magnetic properties, acquisition of GRM, and presence of disturbed intervals in Hole M0063D preclude comparison between the directional data and regional paleomagnetic secular variation (PSV) master curves applicable to the Holocene.

\section{Microbiology}

Hole M0063E was drilled specifically for microbiology, interstitial water chemistry, and unstable geochemical parameters at Site M0063. Counts of microbial cells were made on board the ship by fluorescence microscopy using acridine orange direct counts (AODC) and by flow cytometry (FCM) using SYBR green I DNA stain. Additional AODC were also made during the Onshore Science Party (OSP). Further counts by fluorescence microscopy will be done after the OSP using both acridine orange and SYBR green I staining.

Microbial cells were enumerated at 67 sediment depths from independently taken samples for FCM (66 samples) and AODC (32 samples), both on the ship and during the OSP (Table T12).

The most striking observations for these data are the extremely high cell densities determined by AODC 
near the top of this hole and the fact that the two cell counting techniques do not produce similar results in the upper half of the hole (Fig. F23). The uppermost cell count at 1.22 mbsf, by FCM, was $3.72 \times$ $10^{8}$ cells $/ \mathrm{cm}^{3}$, whereas $6.53 \times 10^{9}$ cells $/ \mathrm{cm}^{3}$ was determined by AODC, a 17-fold difference. Maximum cell numbers in this hole were $1.40 \times 10^{9}$ cells $/ \mathrm{cm}^{3}$ at $15.44 \mathrm{mbsf}$ for FCM counts and $8.77 \times 10^{9}$ cells $/ \mathrm{cm}^{3}$ at $2.65 \mathrm{mbsf}$ for AODC. In the lower half of this hole (deeper than $43 \mathrm{mbsf}$ ), data from both counting techniques appeared similar. The minimum microbial cell numbers were determined as $6.31 \times 10^{7}$ cells $/ \mathrm{cm}^{3}$ at $83.42 \mathrm{mbsf}$ by FCM and $3.24 \times 10^{7}$ cells/ $\mathrm{cm}^{3}$ at 71.52 mbsf by AODC.

Regression analyses of both data profiles indicated different trends shallower and deeper than $43 \mathrm{mbsf}$ (Fig. F23). The decrease in cell numbers with depth was significantly steeper shallower than $43 \mathrm{mbsf}$ compared to deeper than this depth, both for FCM (F $=8.14$; degree of freedom $[\mathrm{df}]=1.62 ; \mathrm{P}<0.01$ ) and AODC $(\mathrm{F}=14.12 ; \mathrm{df}=1.28 ; \mathrm{P}<0.001)$. In the upper $43 \mathrm{~m}$, the change in cell numbers with depth was 2.4 times steeper for AODC compared to FCM. Deeper than $43 \mathrm{mbsf}$, regression lines from the two depth profiles were not significantly different from each other $(\mathrm{F}=0.818$; $\mathrm{df}=1.29$ [not significant]), which was confirmed by a paired sample $t$-test $(\mathrm{t}=$ 0.008; $\mathrm{df}=13$ [not significant]).

The reasons for the split in the data at 43 mbsf do not seem to be directly related to interstitial water chemistry (Fig. F23), as there are no abrupt changes in either alkalinity or salinity at this specific depth. It is, however, interesting to note that the highest cell numbers are observed in the upper part of this hole (to $27 \mathrm{mbsf}$ ), where there are the highest levels of alkalinity, a product of microbial degradation of organic carbon. The profile break at $\sim 43 \mathrm{mbsf}$ seems to be related to stratigraphy with this depth being the approximate transition between laminated and well sorted clays of Unit III above and iron-sulfide laminated clays of Unit IV below (determined in "Lithostratigraphy" as being 41 mbsf). The lithologic change at around 41 mbsf was observed in cores from Holes M0063A, M0063C, and M0063D, whereas cores from the microbiology hole (M0063E) were so heavily sampled for microbiology that the remaining core was too disturbed for good stratigraphic description.

It is striking that the two cell counting methods produce two such different depth profiles. All samples taken for AODC were counted from the surface to 5 mbsf and were also counted from 28.2 mbsf to the base of the hole. In the $23 \mathrm{~m}$ deep interval between these two depths, 21 samples were taken for counting by AODC, but only 5 of these were actually pro- cessed because of difficulties with preparing the other 16 samples for counting. After staining, cells were observed in large clumps of "fluff," which made counting of individual cells impossible. An improved processing technique will need to be developed to deal with these samples. This fluff is likely to be bacterially derived exopolysaccharide causing cell clumping. It is of note that this depth interval of difficult-to-count samples coincides with both the largest differences between the two counting techniques and the presence of very organic rich sediments (Fig. F17B). Over this depth interval, all samples for FCM counting were processed and counted, yet there are two major observations that may explain the reduced counts. First, after sonication, the samples were filtered through a $40 \mu \mathrm{m}$ filter and any bacterial clumps that had resisted sonication would be filtered out of the sample, thus significantly reducing the final count. Second, casual observation suggested that this depth interval in the sediment had large numbers of very small cells of $\sim 0.1 \mu \mathrm{m}$ diameter that FCM could not detect. Missing these small cells caused a reduction in the FCM count. Figure F24 shows samples stained by SYBR green I. The fluff was visualized but with too many cells to count. After sonication and HF treatment, both very small cells and clumps of cells can be seen. We estimated that $>20 \%$ of total cells were $0.1 \mu \mathrm{m}$ in diameter or perhaps even smaller.

As reported for Sites M0059, M0060, and M0061, cell numbers were very high and, with one exception, all cell counts exceeded the global regression (Fig. F23). The maximum deviation from the global regression was at 15.44 mbsf in the profiles from both techniques. The FCM count was 80 -fold higher, and the AODC technique gave a result 265 -fold higher.

When the data from both techniques are plotted against each other, results from deeper than $43 \mathrm{mbsf}$ cluster around the line of $\mathrm{x}=\mathrm{y}$ (Fig. F25). Data are too clustered for a regression line to be calculated and compared to the $\mathrm{x}=\mathrm{y}$ line. Results from shallower than 43 mbsf clearly deviate from the $\mathrm{x}=\mathrm{y}$ line.

PFC was above detection in the liner fluid and exteriors of all cores, indicating continuous PFC delivery into the borehole (Table T13). Liner fluid PFC concentrations fluctuated over 2-3 orders of magnitude (Fig. F26), indicating variations in the rate of PFC injection or mixing into the drilling fluid stream. Generally, the measured PFC concentrations were considerably below the target concentration of $1 \mathrm{mg}$ PFC/L. Despite the variations, PFC was above detection in the vast majority of core halfway and interior sections. Interestingly, and contrasting with the other stations where contamination was most pro- 
nounced near the top of the hole, the uppermost cores, 347-M0063E- $1 \mathrm{H}$ and $2 \mathrm{H}$, have no detectable contamination in the interior. This might in part be due to low PFC concentrations in liner fluids in these cores, which would lower the PFC detectability in the cores compared to cores with high liner fluid PFC concentrations. Deeper than these top cores, and as at the other stations, there is no clear depthor lithology-related trend in the level of contamination (Table T13; Fig. F23). The most highly contaminated cores are Cores 347-M0063E-3H, 4H, 30H, $31 \mathrm{H}$, and $42 \mathrm{H}$, which have potential contaminant cell densities of $>10^{4}$ cells $/ \mathrm{cm}^{3}$ in core interiors (Fig. F26).

Based on the PFC data and calculated contamination with microbes from drilling fluid, Cores 347M0063E-1H, $2 \mathrm{H}, 16 \mathrm{H}$, and $17 \mathrm{H}$, in which PFC was below detection, are suitable for microbiological analyses. Moreover, the interiors of Cores $5 \mathrm{H}, 10 \mathrm{H}$, $12 \mathrm{H}, 25 \mathrm{H}$, and $41 \mathrm{H}$, have calculated potential contaminant cell numbers $<100$ cells $/ \mathrm{cm}^{3}$ sediment and are thus at most moderately contaminated (Table T13). The in situ communities of microbial cells, $10^{8}-10^{9}$ cells $/ \mathrm{cm}^{3}$, are more than a million-fold more abundant than this potential contamination level.

\section{Stratigraphic correlation}

Five holes were drilled at Site M0063: Holes M0063A (115.81 mbsf), M0063B (29.00 mbsf), M0063C (96.4 mbsf), M0063D (86.8 mbsf), and M0063E (92.8 mbsf). Hole M0063E was a microbiology hole and was sampled intensively down to $\sim 70$ mbsf. The meters composite depth (mcd) scale for Site M0063 was based on correlation of magnetic susceptibility and natural gamma between holes. Cored material was heavily expanding to a depth of $\sim 60 \mathrm{mbsf}$, resulting in loss of sediment in Hole M0063A. Holes M0063B, M0063C, M0063D, and M0063E were drilled with a modified strategy (see "Operations"), giving core material more space to expand inside the core liner. This approach minimized sediment loss but also resulted in disturbances at the top of each core. In MSCL data, the disturbed core tops were seen as strong noise; this could later be verified from split cores (Fig. F27).

Because of expansion, the original meters below seafloor scale was partially overlapping between cores (Fig. F27), with the base of one core appearing to sit below the top of the core beneath it. Before correlation, all magnetic susceptibility data were cleaned for the top $10-80 \mathrm{~cm}$ of each section, removing any measured outliers. In Hole M0063E, a heavily sampled microbiology hole, only Fast-track magnetic susceptibility data were available from the whole length, in addition to natural gamma and normal MSCL measurements from unsampled core parts. The correlation was checked against scanned core slab images and sedimentological interpretations. Some prominent sedimentological features were difficult to align, so in these cases correlation was based more on MSCL and natural gamma data. Within the uppermost $30 \mathrm{mbsf}$, correlation was possible within $0.5 \mathrm{~m}$ error margin. From 30 to $60 \mathrm{mbsf}$, it was possible to achieve $1-0.5 \mathrm{~m}$ accuracy and from 60 to 90 mbsf $0.5 \mathrm{~m}$ accuracy. The depth offsets that define the composite section for Site M0063 are given in Table T14 (affine table).

This was the first site where compression of the original meters below seafloor scale in ratio to sediment expansion was tested, according to the following equation:

Corrected total depth $=$ real bottom depth of core [(expanded bottom depth of core $\left.-T_{\text {depth }}\right) \times$ (real length of core/expanded length of core)],

where the real length of core is equal to the length drilled and $T_{\text {depth }}=$ total depth. This adjustment did not appear to significantly improve accuracy, probably because expansion was not linear throughout the hole. Comparison of downhole log gamma and natural gamma from Hole M0063A (Fig. F28) indicates that although the upper part of individual cores were disturbed, there did not seem to be large gaps in core recovery.

The uppermost 20 mbsf was somewhat disturbed. Between $\sim 22$ and $42 \mathrm{mbsf}$, expansion/sediment loss was at its greatest (30\%-40\%). Another possibly disturbed interval started around $84 \mathrm{mbsf}$ and extended down to $\sim 100$ mbsf. Because of the potential for relatively large error margins due to nonlinear expansion, no splice was constructed at Site M0063.

No correction was therefore made for expansion or compression to the data, so the offset within each core was equal for all points. Therefore, it is possible that some features are not similarly aligned between holes.

\section{Seismic units}

Seismic sequence boundary-sediment core-MSCL log (magnetic susceptibility) correlations are shown in Figure F29. Correlation is based on the integration of seismic data and lithostratigraphy (see "Lithostratigraphy"). Two-way traveltime values were calculated for each lithostratigraphic unit boundary using sound velocity values measured during the OSP (see "Physical properties"; Table T15). Lithostratigraphic units/unit boundaries were examined at these calculated two-way traveltime values to define 
the extent of agreement between seismic boundaries and actual lithologic and/or physical properties disconformable surfaces. Uncertainties in the timedepth function and effects of gas-saturated sediments could have resulted in moderate inconsistencies between seismic features, sedimentological observations from the cores, and the MSCL logs.

\section{Seismic Unit I}

Two-way traveltime: $631 \mathrm{~ms}$

Lithology: organic-rich clays (lithostratigraphic Subunits Ia-Id)

Depth: 0-25 mbsf

The lithostratigraphic Unit I upper surface (two-way traveltime $=611 \mathrm{~ms}$ ) does not coincide with the seismic profile. This could be due to small temperature (and salinity) differences in the water column; the calculation was based on the assumption that the water temperature is $+4^{\circ} \mathrm{C}$. The lower boundary of Unit I seems to coincide with a more clearly defined reflector within a transparent, homogeneous unit. Therefore, the low velocity value $(1200 \mathrm{~m} / \mathrm{s})$ for the uppermost organic-rich clay seems to be valid.

\section{Seismic Unit II}

Two-way traveltime: $644 \mathrm{~ms}$

Lithology: gray clay, upper part iron sulfide laminations and massive lower part (Subunits IIa and IIb)

Depth: 25-34 mbsf

\section{Seismic Unit III}

Two-way traveltime: $654 \mathrm{~ms}$

Lithology: mixed clay sediments with contorted lamina (lithostratigraphic Subunits IIIa and IIIb)

Depth: 34-41 mbsf

\section{Seismic Unit IV}

Two-way traveltime: $663 \mathrm{~ms}$

Lithology: iron sulfide laminated gray clay which changes gradually into varved clays (lithostratigraphic Subunits IVa and IVb)

Depth: 41-48 mbsf

\section{Seismic Unit V}

Two-way traveltime: $670 \mathrm{~ms}$

Lithology: contorted convolute bedded clay (lithostratigraphic Unit V)

Depth: 48-53 mbsf

\section{Seismic Unit VI}

Two-way traveltime: $725 \mathrm{~ms}$
Lithology: varved clay downward-increasing silt and sand content and with dispersed pebbles (lithostratigraphic Unit VI)

Depth: 53-92 mbsf

The Unit VI lower boundary coincides with a boundary between different seismic units. In places, seismic Unit VI has a layered/parallel inner structure; in other places it seems more homogeneous.

\section{Seismic Unit VII}

Lithology: sandy diamict

Depth: 92-93 mbsf

For Unit VII there is no information about the lower boundary. Based on seismic profiles, it seems that unit contains silt and sand material.

\section{Downhole measurements}

\section{Logging operations}

Hole M0063A was drilled with a $210 \mathrm{~mm}$ (81/2 inch) rotary coring bit (Rock Roller) from the seafloor to $115.8 \mathrm{~m}$ drilling depth below seafloor (DSF). In preparation for logging, the hole was circulated with seawater and the drill string was pulled back in the hole to $17.5 \mathrm{~m}$ wireline log depth below seafloor (WSF). Logging operations started in Hole M0063A with rigging up the Weatherford logging setup.

For downhole logging in Hole M0063A, three tool strings were deployed. The gamma ray tool (MCG)/ array induction tool (MAI) tool string, measuring natural gamma ray and electrical resistivity, was run from the seafloor to $108.5 \mathrm{~m}$ WSF, where an upload was started. The MCG/spectral gamma ray tool (SGS)/sonic sonde (MSS) tool string, measuring total gamma ray, spectral gamma ray, and sonic velocity, was run from the seafloor to $108.5 \mathrm{~m}$ WSF and an uplog was started. The MCG/microimager (CMI) tool string, measuring total gamma ray and microimages, was also run from the seafloor to $108.5 \mathrm{~m} \mathrm{WSF}$, and a high-resolution uplog was started.

The tools provided continuous and good quality log data.

\section{Logging units}

Hole M0063A was divided into four logging units on the basis of the logs (Fig. F30). The uplog was used as the reference to establish the wireline log depth below seafloor depth scale. Total gamma ray values from different tool strings correlate well. The resistivity log shows a general increasing trend because of increasing compaction of the sediments. 


\section{Logging Unit 1: base of drill pipe to $30 \mathrm{~m} \mathrm{WSF}$}

This logging unit is characterized by a strong increase in natural gamma ray with significant fluctuations. Natural gamma ray is mainly influenced by thorium and uranium deeper than $25 \mathrm{~m}$ WSF. Resistivity slightly increases and sonic logs remain constant in this interval. This corresponds to lithostratigraphic Unit Id composed of organic-rich diatombearing clays (see "Lithostratigraphy").

\section{Logging Unit 2: 30-42 m WSF}

Logging Unit 2 is marked by high natural gamma ray values with large fluctuations. From 30 to $38 \mathrm{~m} \mathrm{WSF}$, there are some washouts where the calipers were open wider than the $210 \mathrm{~mm}$ bit size. Between 32 and $35 \mathrm{~m}$ WSF and between 41 and $43 \mathrm{~m} \mathrm{WSF}$, there are two sudden decreases in NGR: the first one is due to a decrease in potassium, and the second one is due to a decrease in uranium. The first sudden decrease could correspond to lithostratigraphic Subunit IIIa, which is described as gray clay with content of silt and sand (see "Lithostratigraphy"). Resistivity slightly increases as a normal compaction response. The sonic log has constant low values in this unit with a paired aberration between 34.5 and $36.5 \mathrm{~m}$ WSF.

\section{Logging Unit 3: 42-88 m WSF}

Logging Unit 3 shows very high natural gamma ray values of $\sim 150$ gAPI with a slight decrease at the bottom of the unit. Resistivity increases because of compaction throughout the whole unit. The caliper data show excellent borehole conditions. The sonic log shows an increase in velocity between 64 and $76 \mathrm{~m}$ WSF. Except in this interval, the measured velocities are really low, with a minimum of $1250 \mathrm{~m} / \mathrm{s}$ between 78 and $88 \mathrm{~m}$ WSF. These values can usually be observed in saturated shales and clays.

\section{Logging Unit 4: 88-108 m WSF}

Logging Unit 4 from $88 \mathrm{~m}$ WSF downward is characterized by poor hole conditions with several washouts causing large fluctuations in the sonic and resistivity logs. In lithostratigraphic Unit VII, this interval is described as deposit of mass-transport or subglacially deposited till (see "Lithostratigraphy").

\section{References}

Andrén, E., Andrén, T., and Kunzendorf, H., 2000a. Holocene history of the Baltic Sea as a background for assessing records of human impact in the sediments of the Gotland Basin. Holocene, 10(6):687-702. doi:10.1191/ 09596830094944
Andrén, E., Andrén, T., and Sohlenius, G., 2000b. The Holocene history of the southwestern Baltic Sea as reflected in a sediment core from the Bornholm Basin. Boreas, 29(3):233-250. doi:10.1111/j.15023885.2000.tb00981.x

Andrén, T., Björck, S., Andrén, E., Conley, D., Zillén, L., and Anjar, J. 2011. The development of the Baltic Sea Basin during the last $130 \mathrm{ka}$. In Harff, J., Björck, S., and Hoth, P. (Eds.), Central and Eastern European Development Studies (CEEDES): The Baltic Sea Basin: Berlin (SpringerVerlag), 75-97. doi:10.1007/978-3-642-17220-5_4

Andrén, T., Jørgensen, B.B., Cotterill, C., Green, S., Andrén, E., Ash, J., Bauersachs, T., Cragg, B., Fanget, A.-S., Fehr, A., Granoszewski, W., Groeneveld, J., Hardisty, D., Herrero-Bervera, E., Hyttinen, O., Jensen, J.B., Johnson, S., Kenzler, M., Kotilainen, A., Kotthoff, U., Marshall, I.P.G., Martin, E., Obrochta, S., Passchier, S., Quintana Krupinski, N., Riedinger, N., Slomp, C., Snowball, I., Stepanova, A., Strano, S., Torti, A., Warnock, J., Xiao, N., and Zhang, R., 2015. Methods. In Andrén, T., Jørgensen, B.B., Cotterill, C., Green, S., and the Expedition 347 Scientists, Proc. IODP, 347: College Station, TX (Integrated Ocean Drilling Program). doi:10.2204/ iodp.proc.347.102.2015

Andrén, T., Lindeberg, G., and Andrén, E., 2002. Evidence of the final drainage of the Baltic Ice Lake and the brackish phase of the Yoldia Sea in glacial varves from the Baltic Sea. Boreas, 31(3):226-238. doi:10.1111/ j.1502-3885.2002.tb01069.x

Antonsson, K., Brooks, S.J., Seppä, H., Telford, R.J., and Birks, H.J.B., 2006. Quantitative palaeotemperature records inferred from fossil pollen and chironomid assemblages from Lake Gilltjärnen, northern central Sweden. J. Quat. Sci., 21(8):831-841. doi:10.1002/ jqs. 1004

Gustafsson, B.G., and Westman, P., 2002. On the causes for salinity variations in the Baltic Sea during the last 8500 years. Paleoceanography, 17(3):12.1-12.14. doi:10.1029/ 2000PA000572

Hasle, G.R., and Lange, C.B., 1989. Freshwater and brackish water Thalassiosira (Bacillariophyceae): taxa with tangentially undulated valves. Phycologia, 28(1):120135. doi:10.2216/i0031-8884-28-1-120.1

Hasle, G.R. and Syvertsen, E.E., 1990. Arctic diatoms in the Oslofjord and the Baltic Sea-a bio- and palaeogeographic problem. In Simmola, H. (Ed.), Proceedings of the 10th International Diatom Symposium: Koenigstein, Germany (Koeltz Scientific Books), 285-300.

Hasle, G.R., and Syvertsen, E.E., 1996. Marine diatoms. In Tomas, C.R. (Ed.), Identifying Marine Diatoms and Dinoflagellates: San Diego (Academic Press), 5-385. doi:10.1016/B978-012693015-3/50005-X

Hedenström, A., and Risberg, J., 1999. Early Holocene shore-displacement in southern central Sweden as recorded in elevated isolated basins. Boreas, 28(4):490504. doi:10.1111/j.1502-3885.1999.tb00236.x

Huttunen, M., and Niemi, A., 1986. Sea-ice algae in the northern Baltic Sea. Memo. Soc. Fauna Flora Fenn., 62:5862. 
Ignatius, H., Axberg, S., Niemistö, L., and Winterhalter, B., 1981. Quaternary geology of the Baltic Sea. In Voipio, A. (Ed.), The Baltic Sea. Amsterdam (Elsevier Oceanogr. Ser.), 30:54-104.

Kotilainen, A.T., Arppe, L., Dobosz, S., Jansen, E., Kabel, K., Karhu, J., Kotilainen, M.M., Kuijpers, A., Lougheed, B.C., Meier, H.E.M., Moros, M., Neumann, T., Porsche, C., Poulsen, N., Rasmussen, P., Ribeiro, S., Risebrobakken, B., Ryabchuk, D., Schimanke, S., Snowball, I., Spiridonov, M., Virtasalo, J.J., Weckström, K., Witkowski, A., and Zhamoida, V., 2014. Echoes from the past: a healthy Baltic Sea requires more effort. AMBIO, 43(1):60-68. doi:10.1007/s13280-013-0477-4

Lepland, A., Heinsalu, A., and Stevens, R.L., 1999. The preLittorina diatom stratigraphy and sediment sulphidisation record from the west-central Baltic Sea: implications of the water column salinity variations. GFF, 121(1):57-65. doi:10.1080/11035899901211057

Lovley, D.R., and Phillips, E.J.P., 1987. Competitive mechanisms for inhibition of sulfate reduction and methane production in the zone of ferric iron reduction in sediments. Appl. Environ. Microbiol., 53(11):2636-2641. http://aem.asm.org/content/53/11/2636

Miettinen, A., Head, M.J., and Knudsen, K.L., 2014. Eemian sea-level highstand in the eastern Baltic Sea linked to long-duration White Sea connection. Quat. Sci. Rev., 86:158-174. doi:10.1016/j.quascirev.2013.12.009

Murray, J.W., and Alve, E., 1999. Natural dissolution of modern shallow water benthic foraminifera: taphonomic effects on the palaeoecological record. Palaeogeogr., Palaeoclimatol., Palaeoecol., 146(1-4):195-209. doi:10.1016/S0031-0182(98)00132-1

Pillet, L., Voltski, I., Korsun, S., and Pawlowski, J., 2013. Molecular phylogeny of Elphidiidae (foraminifera). Mar. Micropaleontol., 103:1-14. doi:10.1016/j.marmicro.2013.07.001

Reinholdsson, M., Snowball, I., Zillén, L., Lenz, C., and Conley, D.J., 2013. Magnetic enhancement of Baltic Sea sapropels by greigite magnetofossils. Earth Planet. Sci. Lett., 366:137-150. doi:10.1016/j.epsl.2013.01.029

Roussel, E.G., Cambon Bonavita, M.-A., Querellou, J., Cragg, B.A., Webster, G., Prieur, D., and Parkes, J.R., 2008. Extending the sub-sea-floor biosphere. Science, 320(5879):1046. doi:10.1126/science.1154545

Schweizer, M., Pawlowski, J., Kouwenhoven, T.J., Guiard, J., and van der Zwaan, B., 2008. Molecular phylogeny of Rotaliida (foraminifera) based on complete small subunit rDNA sequences. Mar. Micropaleontol., 66(3-4):233246. doi:10.1016/j.marmicro.2007.10.003

Snoeijs, P., and Kasperovicienè, J. (Eds.), 1996. Intercalibration and Distribution of Diatom Species in the Baltic Sea (Vol. 4): Uppsala, Sweden (Opulus Press).

Snoeijs, P., Vilbaste, S., Potapova, M., Kasperoviciene, J., and Balashova, J. (Eds.), 1993-1998. Intercalibration and Distribution of Diatom Species in the Baltic Sea (Vol. 1-5): Uppsala, Sweden (Opulus Press).
Snowball, I.F., 1997. Gyroremanent magnetization and the magnetic properties of greigite-bearing clays in southern Sweden. Geophys. J. Int., 129(3):624-636. doi:10.1111/j.1365-246X.1997.tb04498.X

Sohlenius, G., Sternbeck, J., Andrén, E., and Westman, P., 1996. Holocene history of the Baltic Sea as recorded in a sediment core from the Gotland Deep. Mar. Geol., 134(3-4):183-201. doi:10.1016/0025-3227(96)00047-3

Sundelin, U., 1922. Några ord angående förläggningen av transgression ej drabbade delarna av det baltiska området samt angående tidpunkten för Litorinahavets inträde. GFF, 44(3-4):543-44. doi:10.1080/ 11035892209444523

Sundström, B.G., 1986. The marine diatom genus Rhizosolenia: a new approach to the taxonomy [Ph.D. dissert.]. Univ. Gothorum Carolinae, Sweden.

Swanson, K., and van der Lingen, G., 1997. Late Quaternary ostracod and planktonic foraminiferal dissolution signals from the eastern Tasman Sea-paleoenvironmental implications. Palaeogeogr., Palaeoclimatol., Palaeoecol., 131(3-4):303-314. doi:10.1016/S00310182(97)00008-4

Thulin, B., Possnert, G., and Vuorela, I., 1992. Stratigraphy and age of two postglacial sediment cores from the Baltic Sea. GFF, 114(2):165-180. doi:10.1080/ 11035899209453882

Wallin, J.-E., 1996. History of sedentary farming in Ångermanland, northern Sweden, during the Iron Age and Medieval period based on pollen analytical investigations. Veg. Hist. Archaeobot., 5(4):301-312. doi:10.1007/ BF00195298

Wastegård, S., Andrén, T., Sohlenius, G., and Sandgren, P., 1995. Different phases of the Yoldia Sea in the northwestern Baltic proper. Quat. Int., 27:121-129. doi:10.1016/1040-6182(94)00069-H

Westman, P., and Sohlenius, G., 1999. Diatom stratigraphy in five offshore sediment cores from the northwestern Baltic proper implying large scale circulation changes during the last 8500 years. J. Paleolimnol., 22(1):53-69. doi:10.1023/A:1008011511101

Widerlund, A., and Andersson, P.S., 2011. Late Holocene freshening of the Baltic Sea derived from high-resolution strontium isotope analyses of mollusk shells. Geology, 39(2):187-190. doi:10.1130/G31524.1

Zillén, L., and Conley, D.J., 2010. Hypoxia and cyanobacterial blooms are not natural features of the Baltic Sea. Biogeosci. Discuss., 7(2):1783-1812. doi:10.5194/bgd-71783-2010

Zillén, L., Conley, D.J., Andrén, T., Andrén, E., and Björck, S., 2008. Past occurrences of hypoxia in the Baltic Sea and the role of climate variability, environmental change and human impact. Earth-Sci. Rev., 91(1-4):7792. doi:10.1016/j.earscirev.2008.10.001

Publication: 20 February 2015 MS 347-107 
Figure F1. Composite graphic lithology log representing a summary of Hole M0063D, supplemented by information from Hole M0063A. Depths given for Unit I to the start of Unit VI are the recalculated depths, adjusting for expansion, for Hole M0063D. The base of Unit VI and depths for Unit VII come from Hole M0063A.

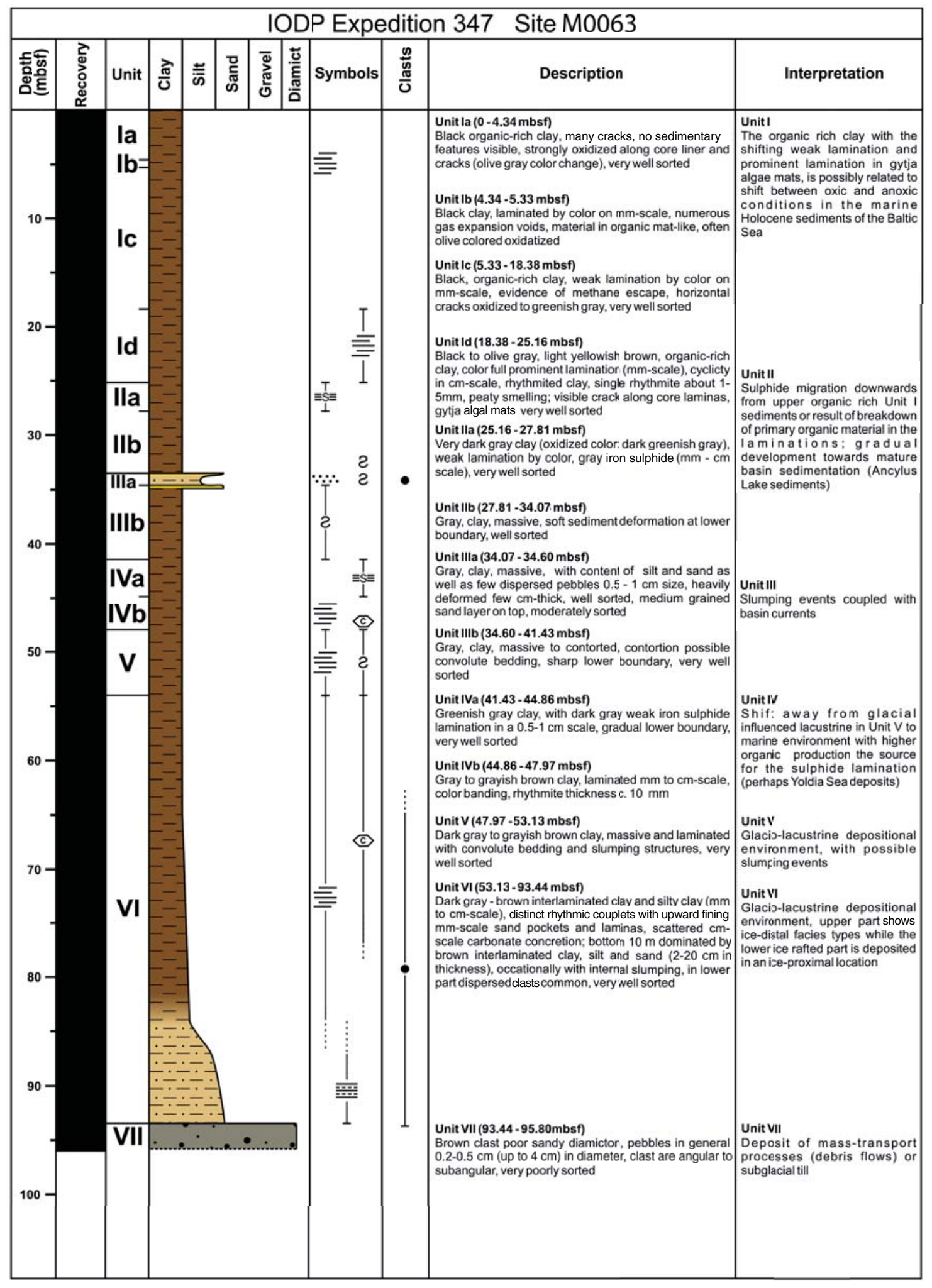




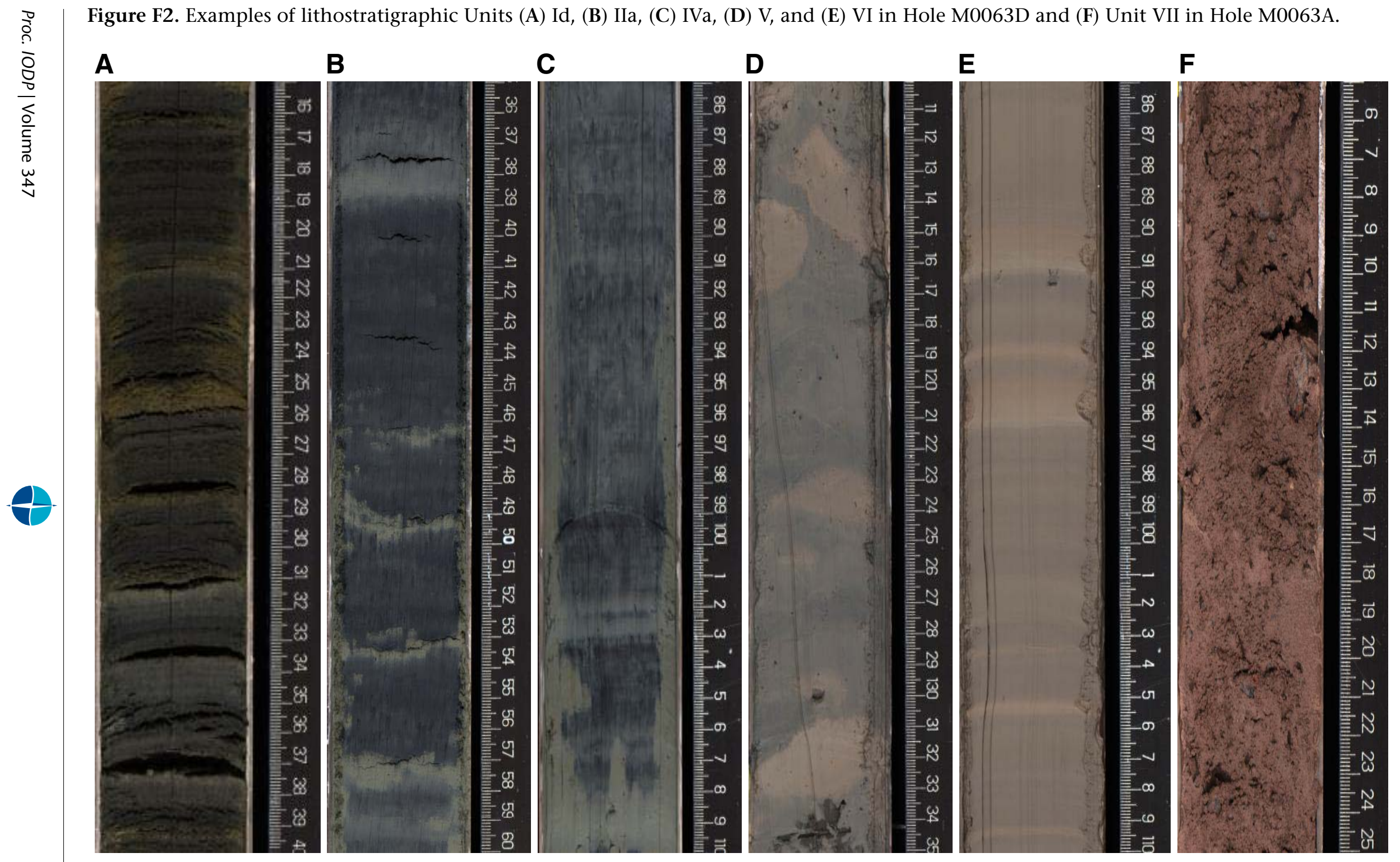


Figure F3. Carbonate concretion (centimeter scale) from Unit VI (Sample 347-M0063A-24H-CC, 4-6 cm).

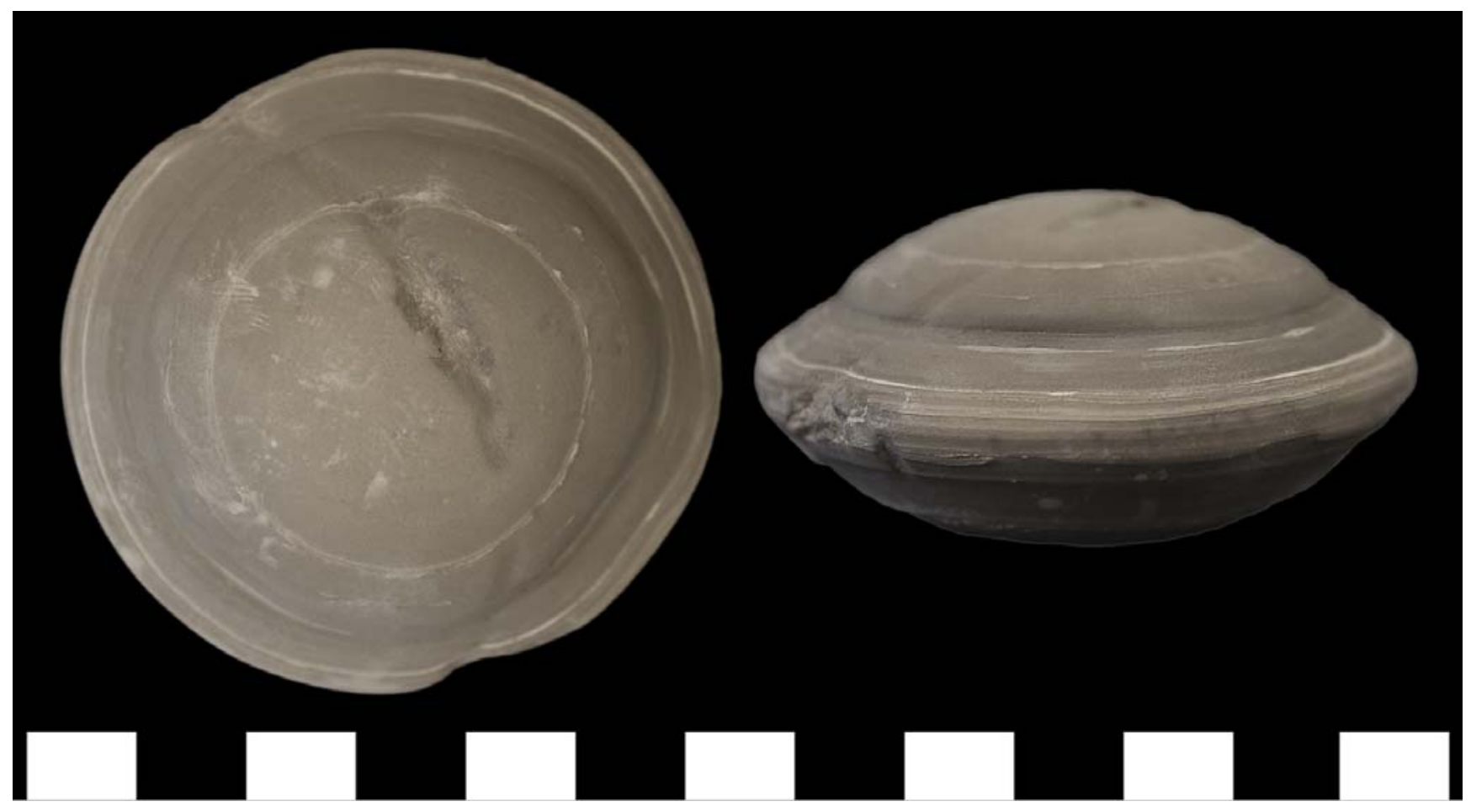


Figure F4. Microscale (centimeter scale) transverse faults displace the laminated clay in Unit VI (interval 347M0063A-20H-2, 72-81 cm).

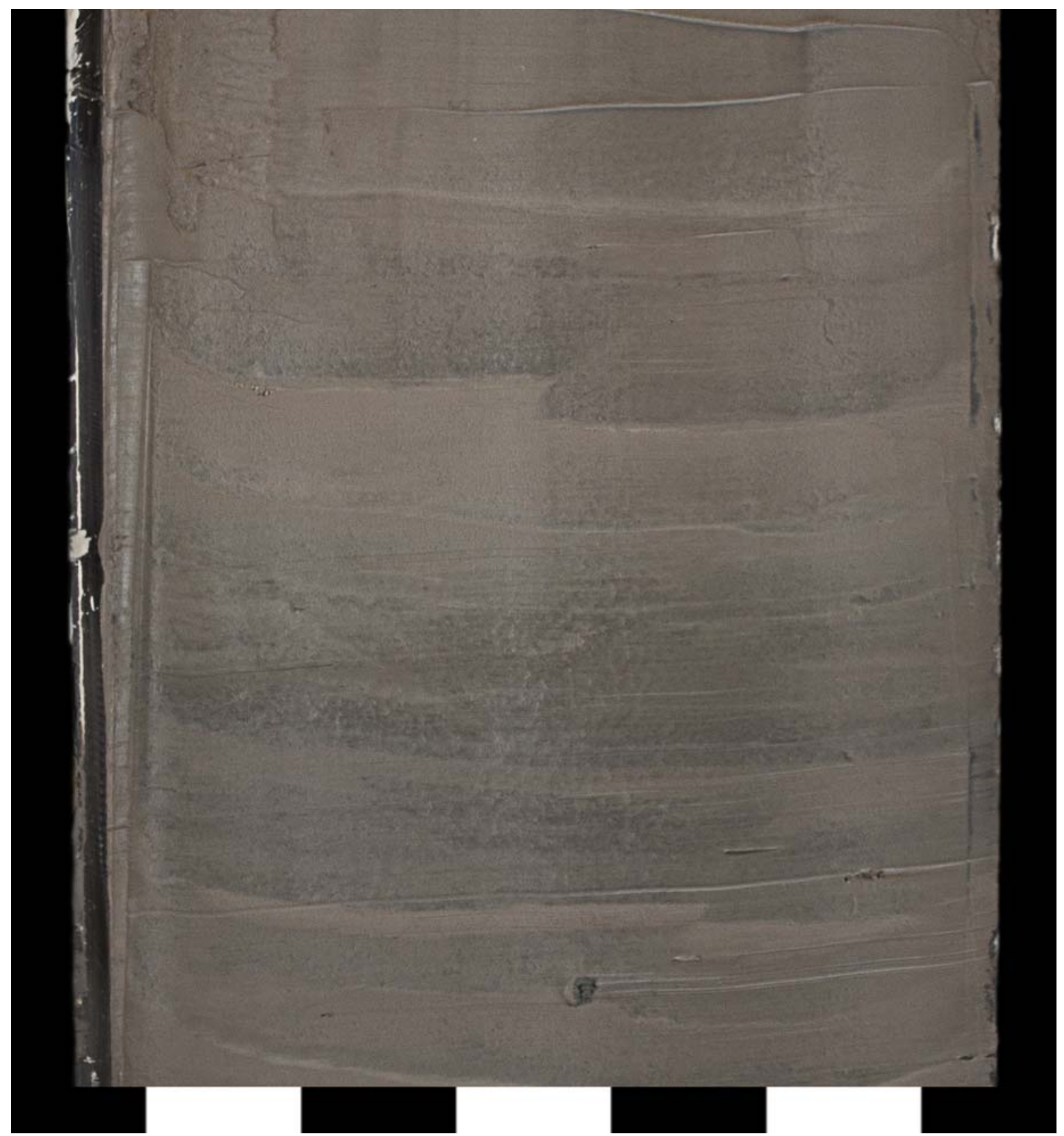


Figure F5. Analyzed levels and the relative proportion of diatom taxa showing different salinity requirements, Hole M0063A. Presence of sea ice related taxa and other siliceous microfossils recorded in the cores are shown (red dots), as well as the number of taxa with planktonic and periphytic life forms. Siliceous microfossil data are only qualitative presence/absence data and should be interpreted cautiously until quantitative data are generated.

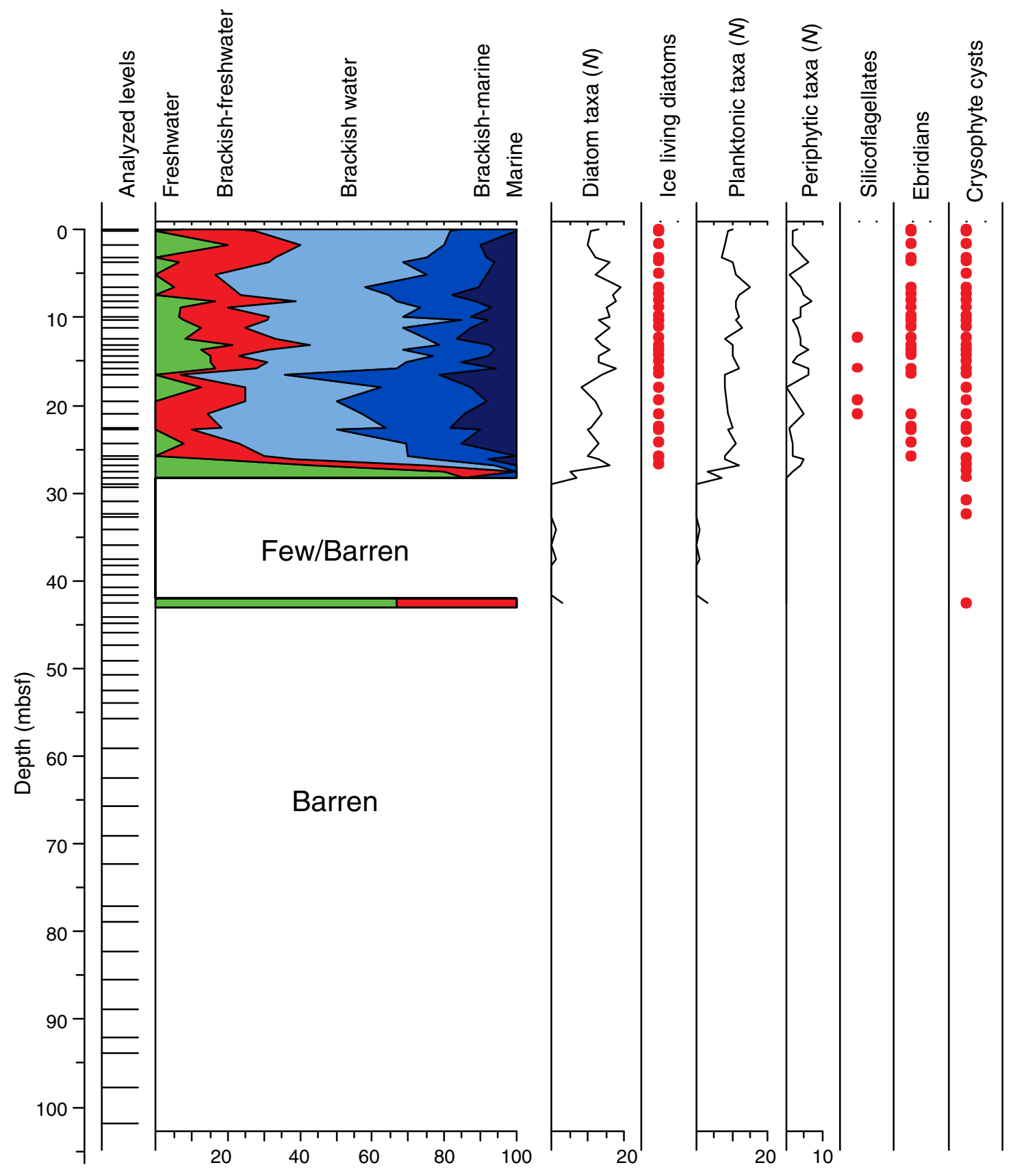


Figure F6. Analyzed levels and the relative proportion of diatom taxa showing different salinity requirements, Hole M0063E. Presence of sea ice related taxa and other siliceous microfossils recorded in the cores are shown (red dots), as well as the number of taxa with planktonic and periphytic life forms. Siliceous microfossil data are only qualitative presence/absence data and should be interpreted cautiously until quantitative data are generated.

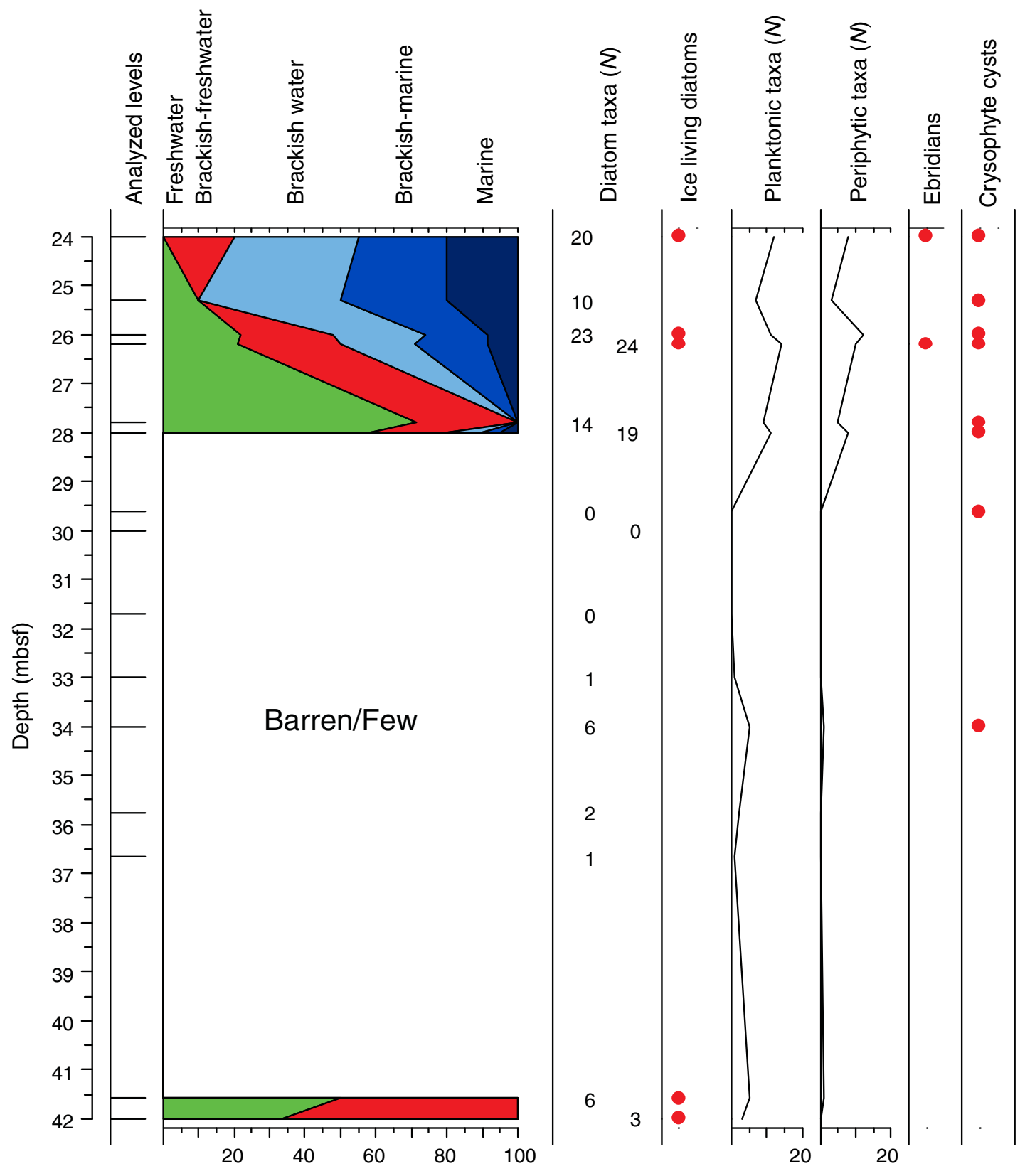


Figure F7. Abundance of benthic foraminifers based on the abundance classification defined in the "Methods" chapter (Andrén et al., 2015), Site M0063. A running average over five samples is plotted onto a single data point. Increasing shading indicates abundances sufficient for faunal and/or geochemical analyses.

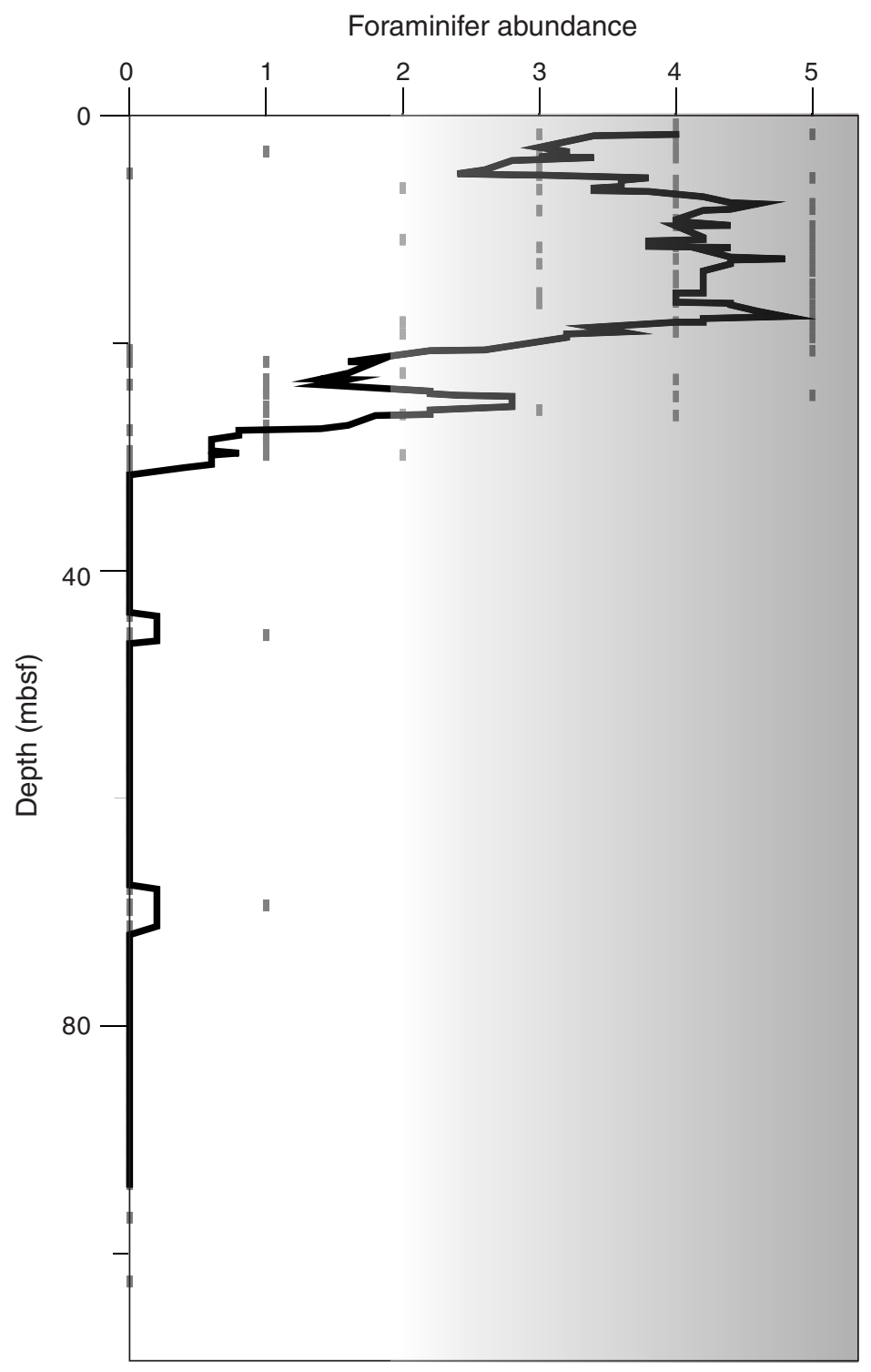


Figure F8. Ostracod abundance per sediment volume, Site M0063.

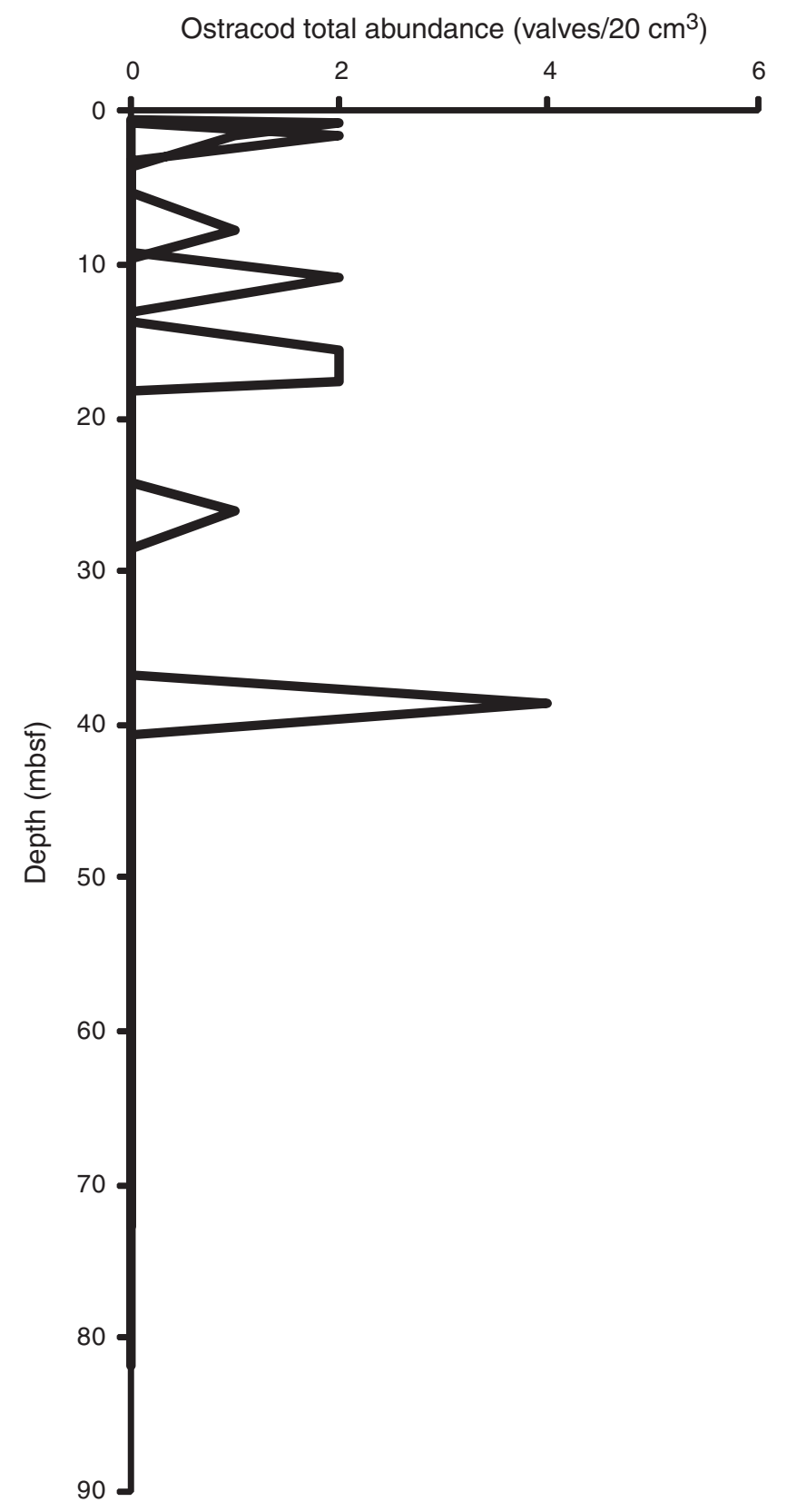


Figure F9. Palynomorphs, Hole M0063A. 1-7. Pollen grains; (1) Triticum (wheat, Core 347-M0063-1H), (2) Poacea (grass, Core 347-M0063A-4H), (3) Alnus (alder, Core 347-M0063A-1H), (4) Fagus (beech, Core 347M0063A-4H), (5) Betula (birch, Core 347-M0063A-8H), (6) Picea (spruce, Core 347-M0063A-4H), (7) Pinus (pine, Core 347-M0063A-4H). 8. Radiosperma (Core 347-M0063A-1H). 9. Thecamoeba, probably Difflugia (Core 347-M0063A-4H). Scale bars $=20 \mu \mathrm{m}$.
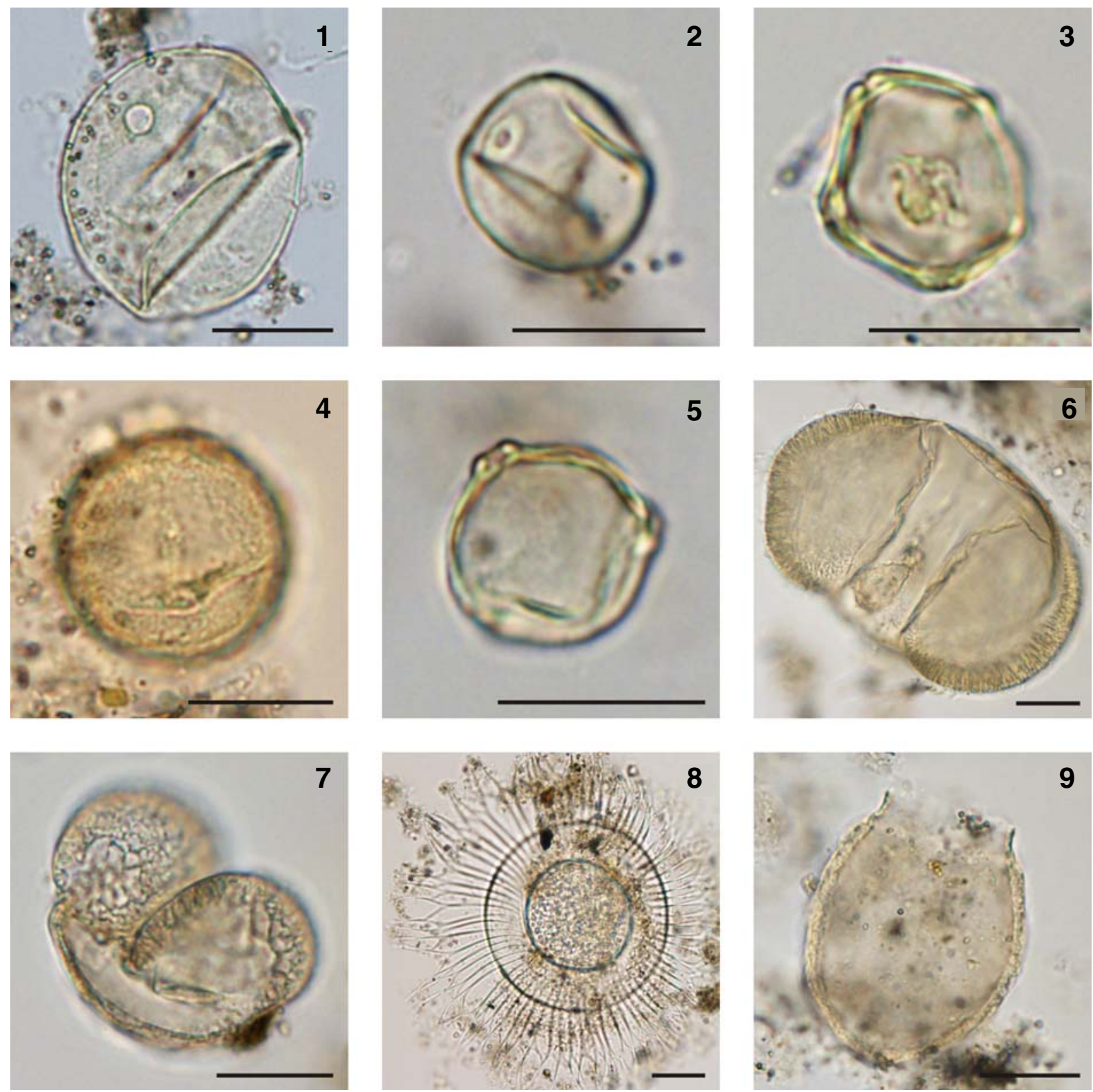


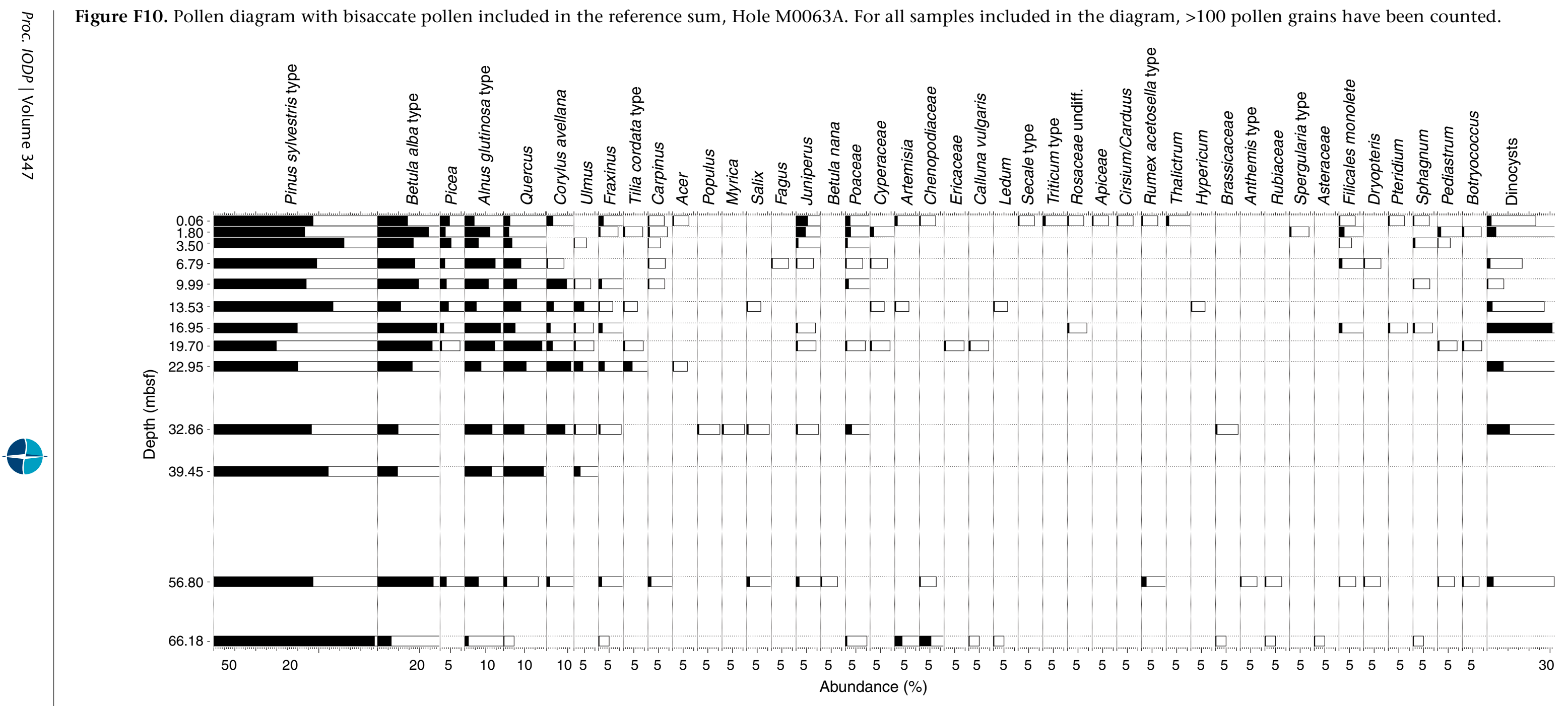


Figure F11. Simplified pollen diagram with dinocyst and further palynomorph data, as well as pollen concentration and pollen grain counting sums, Hole M0063A. Shaded bars = samples with low counting sums (not depicted in Fig. F10).

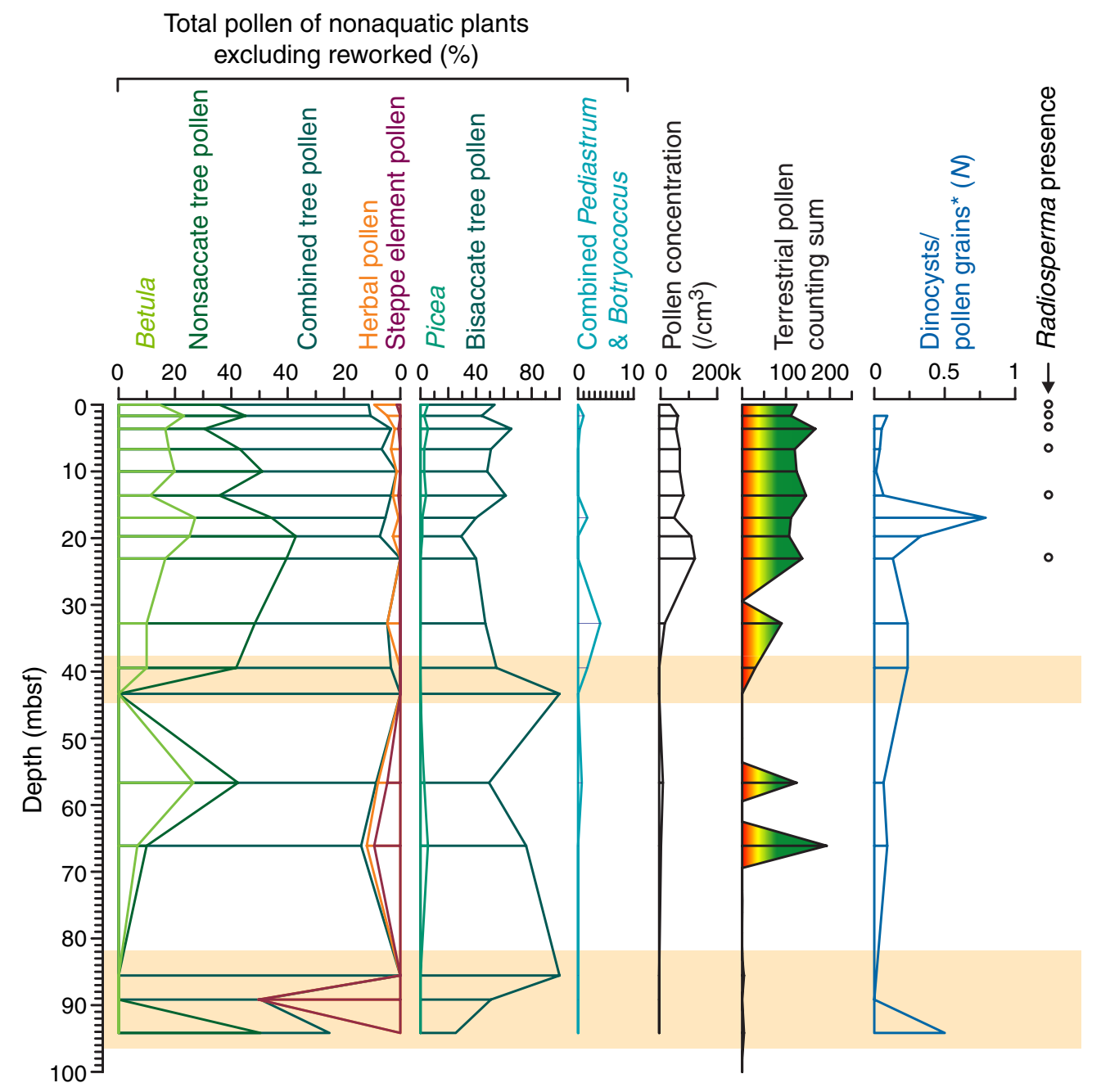


Figure F12. Concentrations of (A) chloride, (B) salinity calculated from refractive index (black symbols) and chloride-based salinity (gray symbols), (C) alkalinity, and (D) anion-based salinity in interstitial water samples, Site M0063.
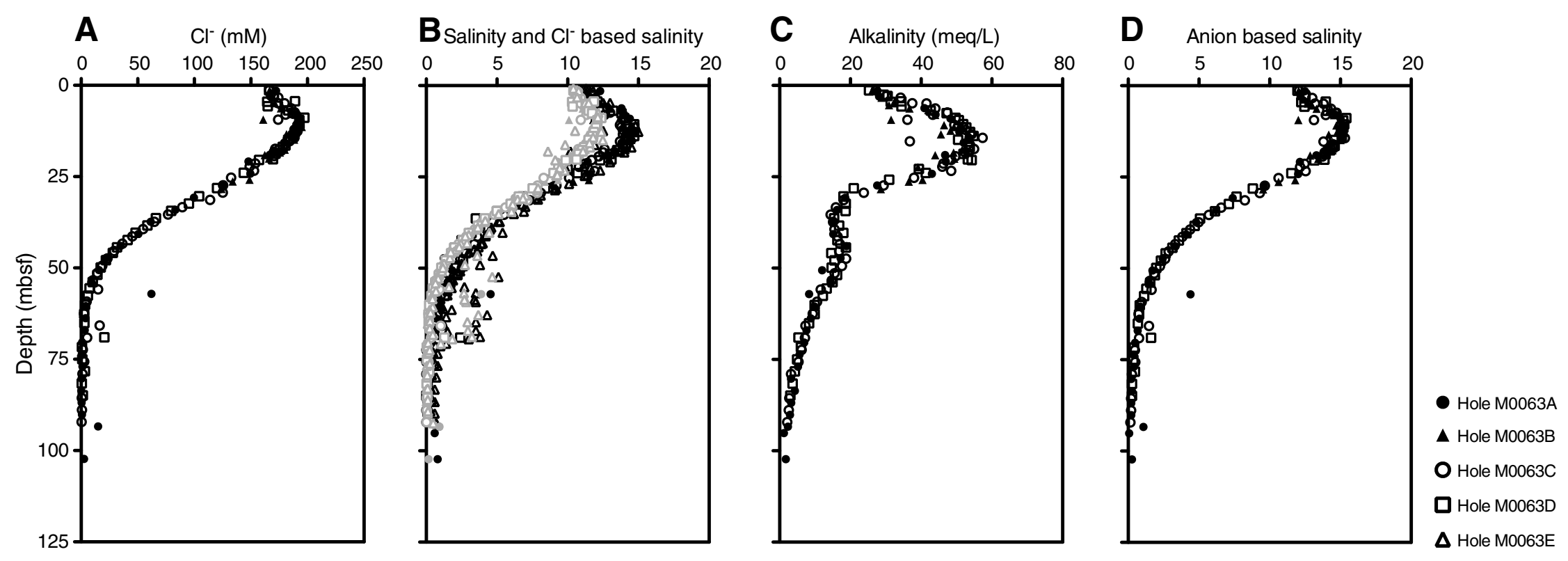
Figure F13. Concentrations of (A) methane, (B) sulfate, (C) sulfide, (D) ammonium, (E) phosphate, (F) iron, (G) manganese, and (H) pH from interstitial water samples, Site M0063.
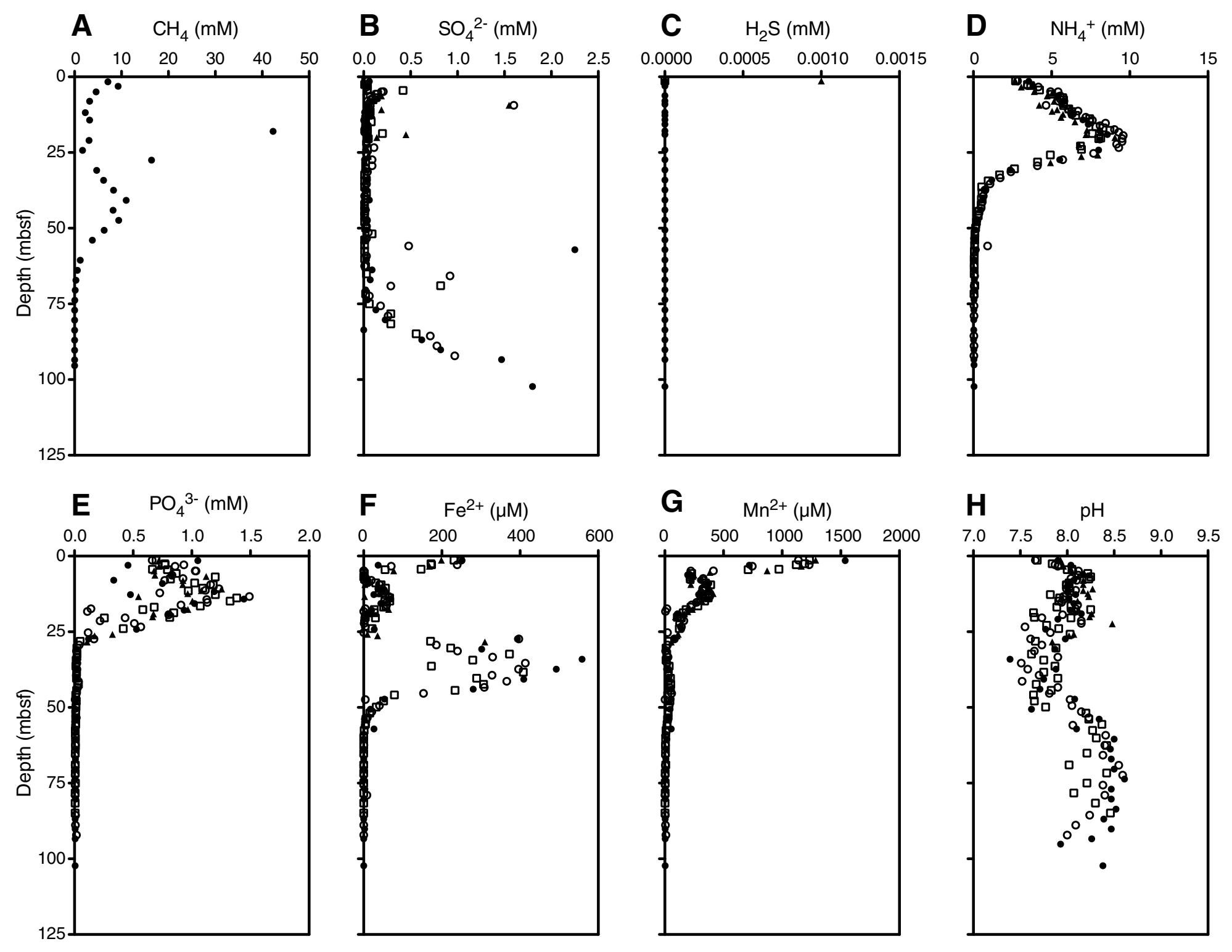

- Hole M0063A

$\Delta$ Hole M0063B

O Hole M0063C

口 Hole M0063D 
Figure F14. Concentrations and ratios of (A) bromide, (B) bromide/chloride, (C) boron, and (D) boron/chloride from interstitial water samples, Site M0063. Dashed lines = seawater ratio.
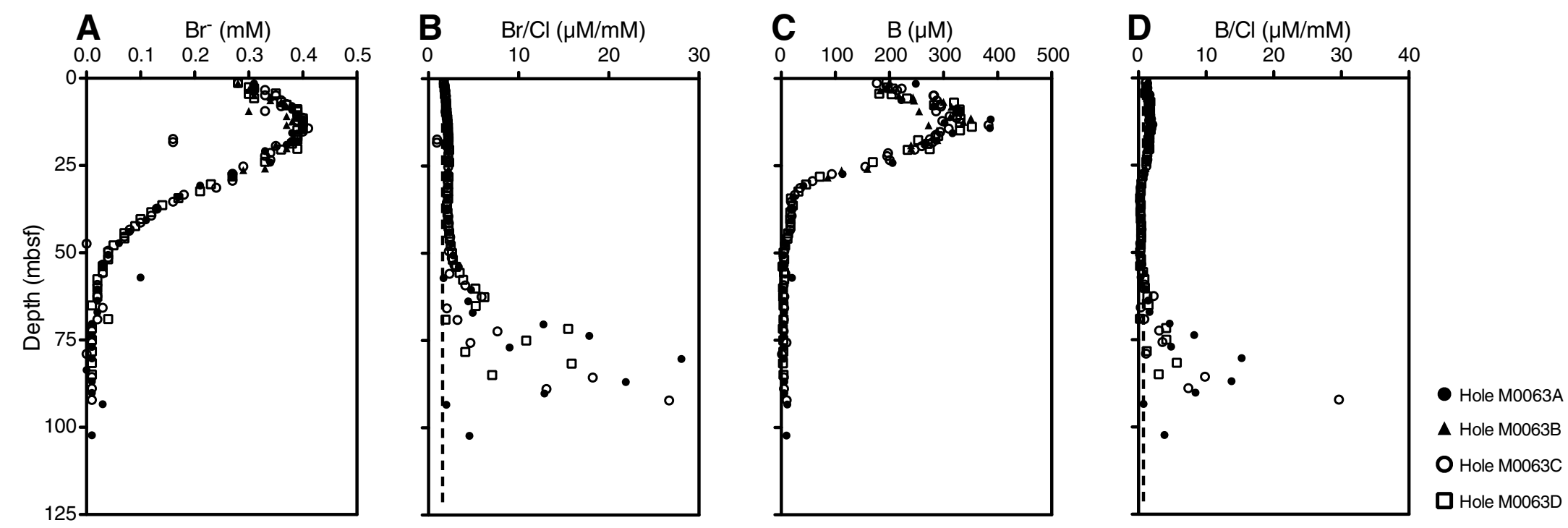
Figure F15. Concentrations and ratios of (A) sodium, (B) potassium, (C) magnesium, (D) calcium, (E) sodium/chloride, (F) potassium/chloride, (G) magnesium/chloride, and (H) calcium/chloride in interstitial water samples, Site M0063. Dashed lines = seawater ratio.
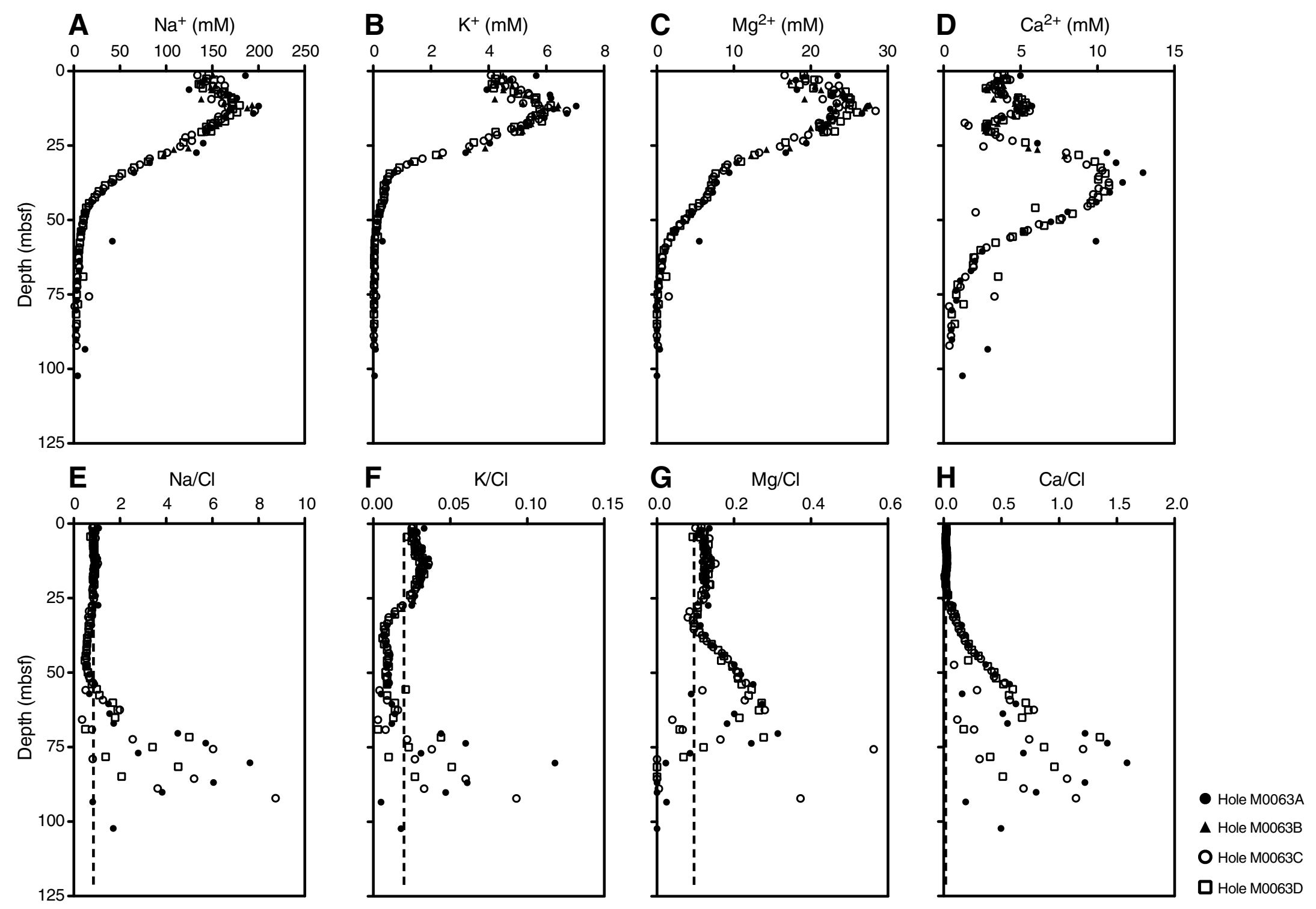
Figure F16. Concentrations of (A) strontium, (B) lithium, (C) dissolved silica, and (D) barium from interstitial water samples, Site M0063.
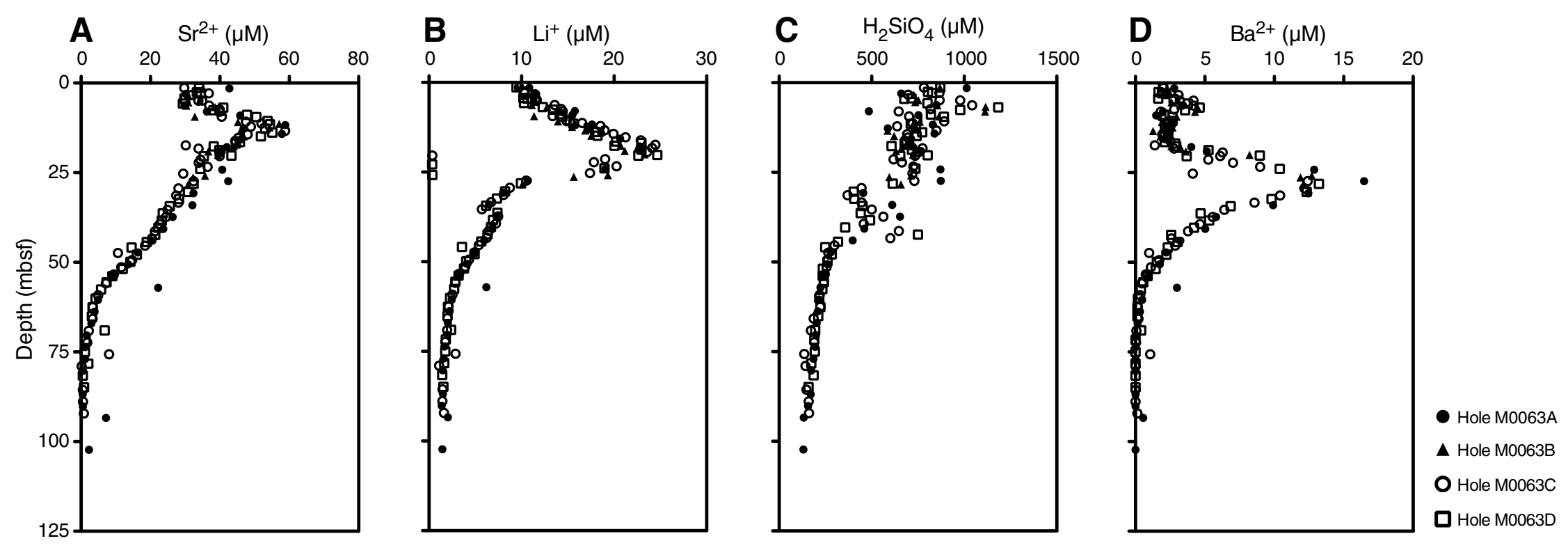
Figure F17. Solid-phase concentrations of (A) total carbon (TC), (B) total organic carbon (TOC), (C) total inorganic carbon (TIC), and (D) total sulfur (TS), Site M0063.
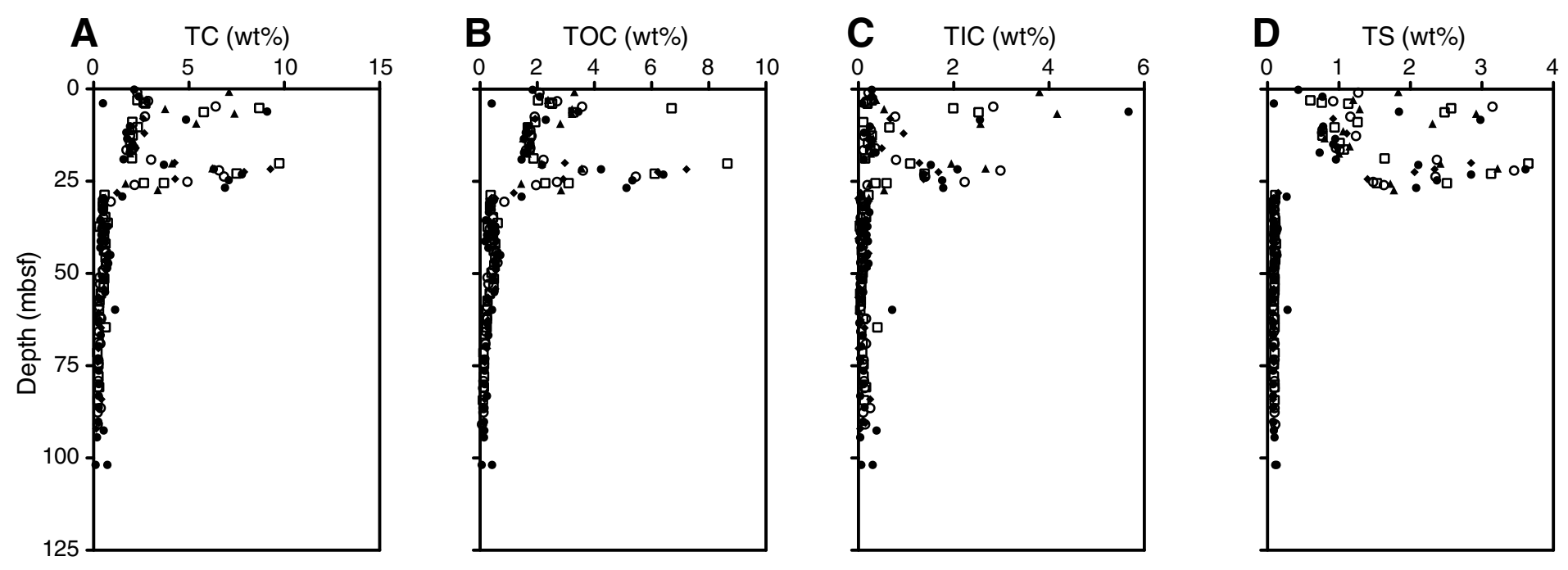

- Hole M0063A

A Hole M0063B

O Hole M0063C

口 Hole M0063D

- Hole M0063E 
Figure F18. Natural gamma radiation (NGR) (cps), magnetic susceptibility (MS) $\left(10^{-5} \mathrm{SI}\right)$, noncontact resistivity $(\mathrm{NCR})(\Omega \mathrm{m})$, and dry density $\left(\mathrm{g} / \mathrm{cm}^{3}\right)$ in Hole M0063C.

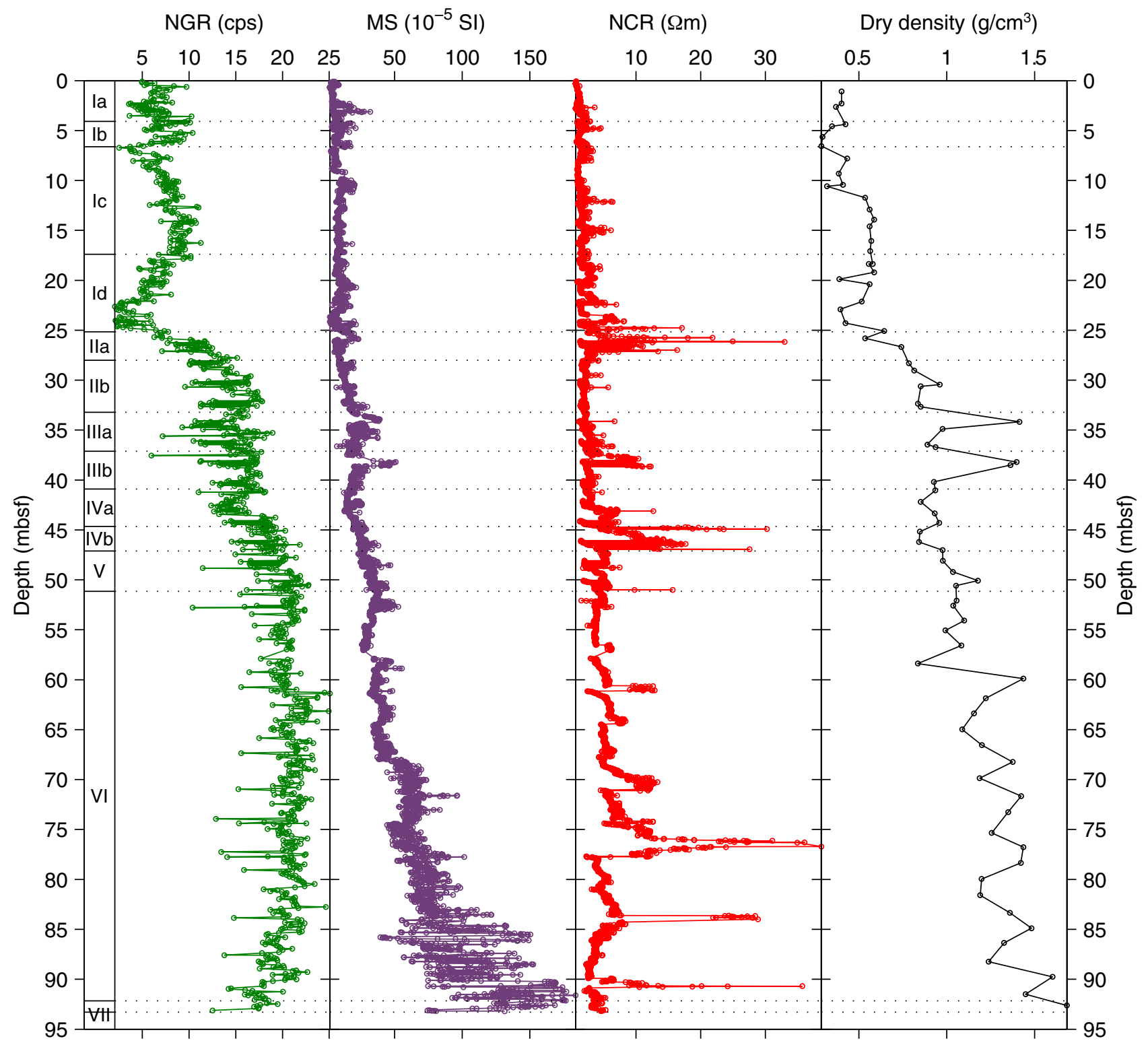


Figure F19. A. Gamma density $\left(\mathrm{g} / \mathrm{cm}^{3}\right)$ compared to discrete bulk density $\left(\mathrm{g} / \mathrm{cm}^{3}\right)$ measurements derived from pycnometer moisture and density analyses in Hole M0063C. B. MSCL $P$-wave velocities $(\mathrm{m} / \mathrm{s})$ compared to discrete measurements in Hole M0063C.

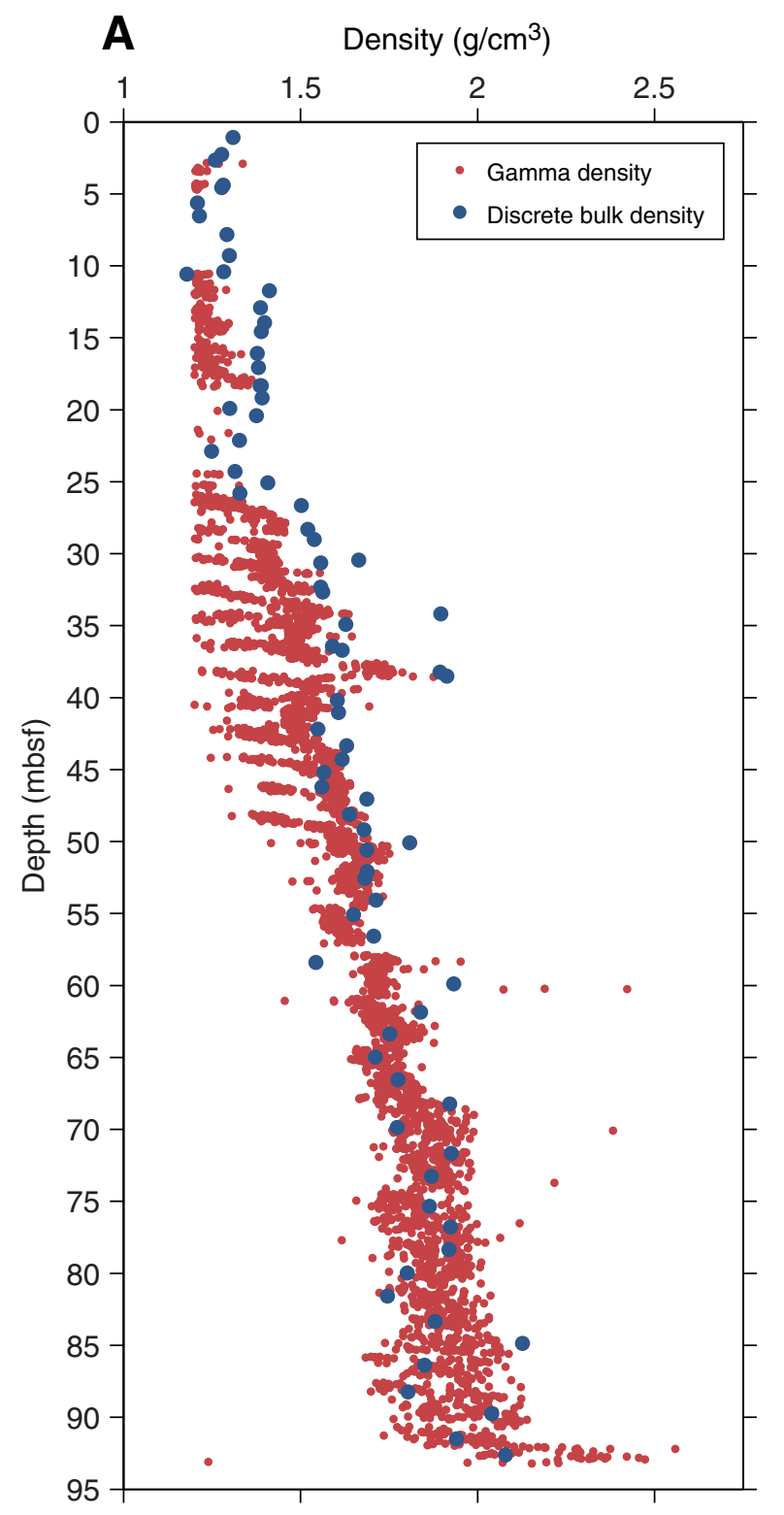

B $\quad P$-wave velocity $(\mathrm{m} / \mathrm{s})$

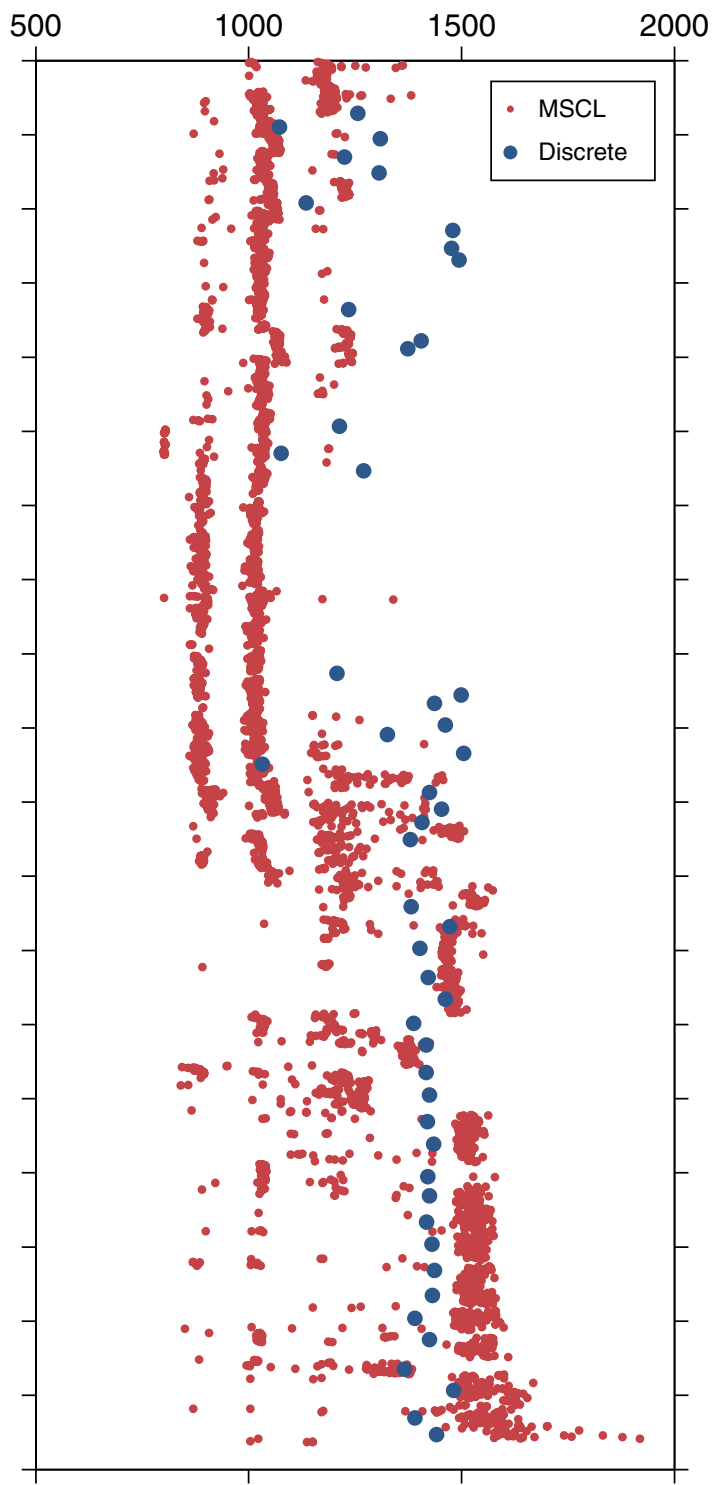


Figure F20. Correlation between gamma density $\left(\mathrm{g} / \mathrm{cm}^{3}\right)$ and discrete bulk density $\left(\mathrm{g} / \mathrm{cm}^{3}\right)$ measurements in Hole M0063C.

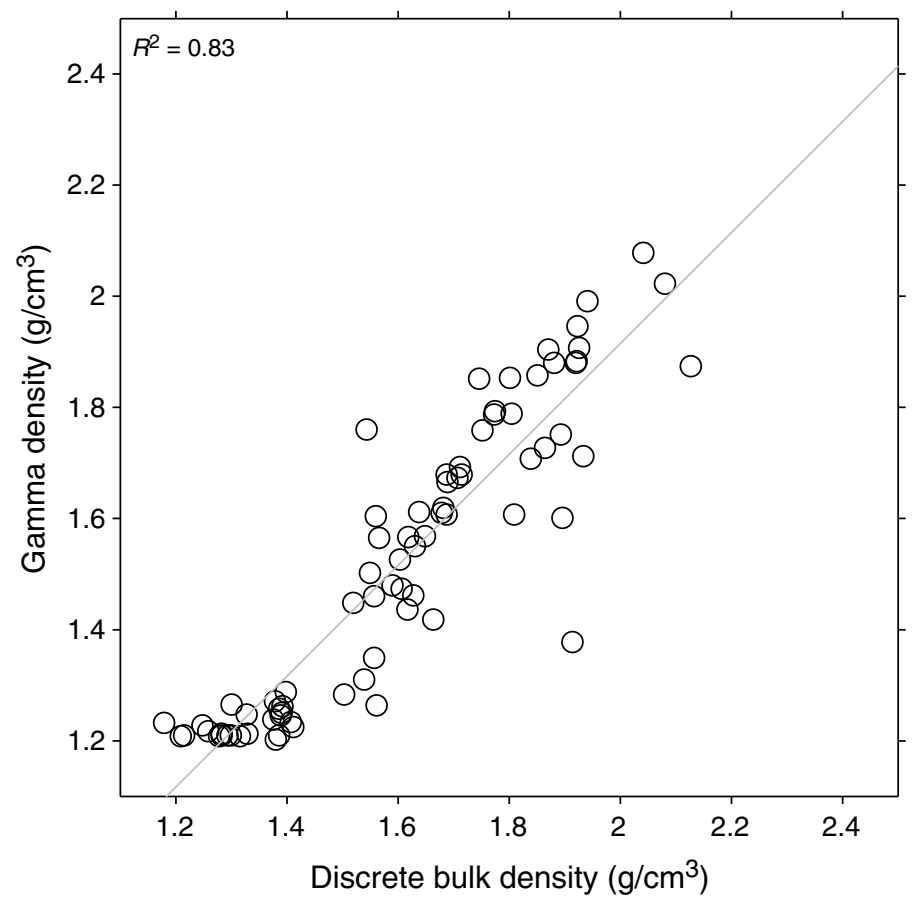


Figure F21. Plots and biplots of magnetic susceptibility $(\chi)$, natural remanent magnetization (NRM) intensity, and NRM inclination of discrete paleomagnetic samples, Hole M0063D. Dashed line $=$ geocentric axial dipole $($ GAD) prediction of inclination for the site latitude. Red dots $=$ samples from the upper $0.75 \mathrm{~m}$ of each core run that showed signs of contamination by rust. AF = alternating field.
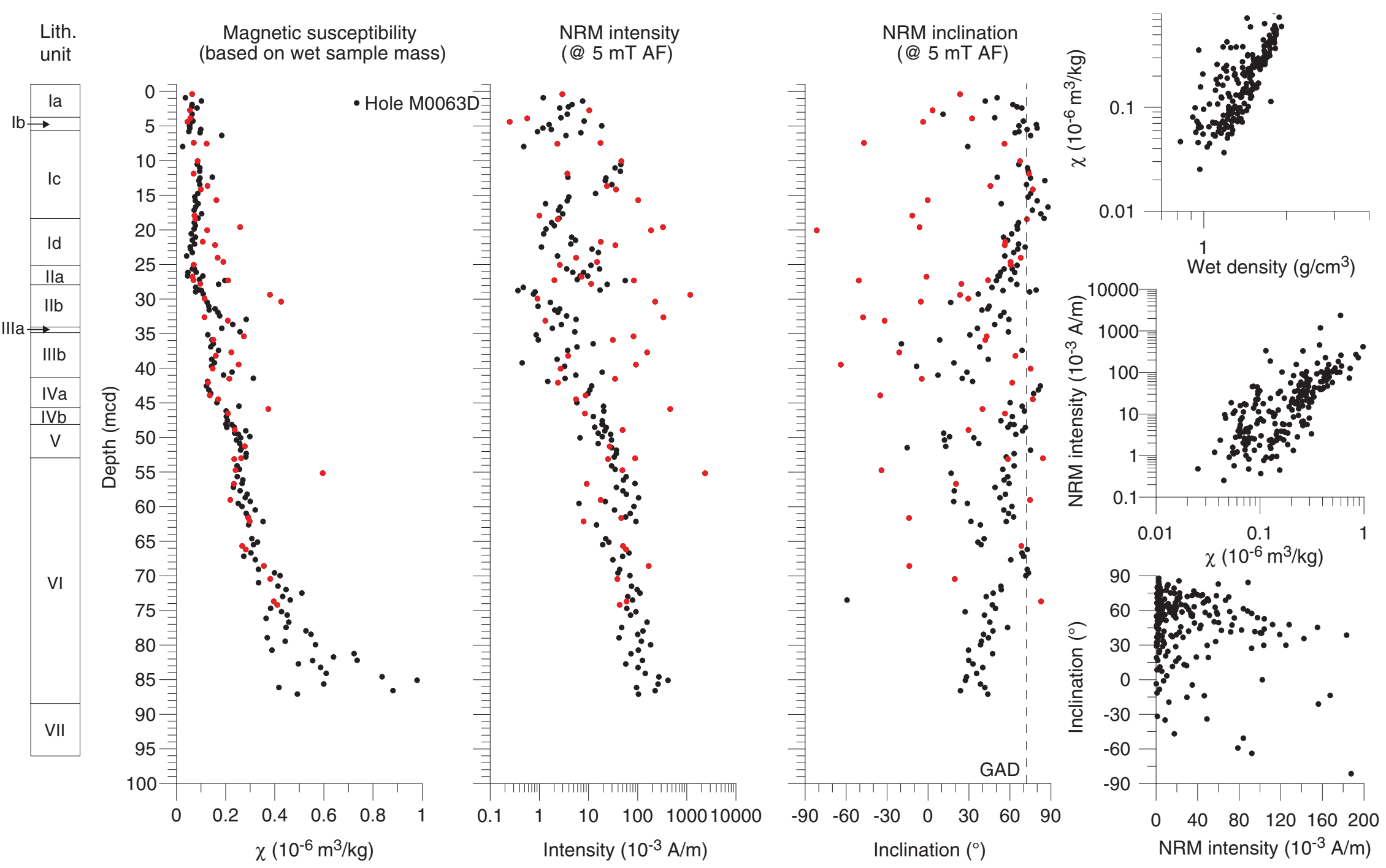
Figure F22. Plots of natural remanent magnetization (NRM) after alternating field (AF) demagnetization to 80 mT. A. Sample 347-M0063D-7H-2, $43 \mathrm{~cm} ; 13.29$ mbsf (15.25 mcd). B. Sample 347-M0063D-14H-1, $53 \mathrm{~cm}$; $25.53 \mathrm{mbsf}$ (27.27 mcd). C. Sample 347-M0063D-23H-2, $12 \mathrm{~cm} ; 44.62 \mathrm{mbsf}(45.48 \mathrm{mcd})$. D. Sample 347M0063D-40H-1, $123 \mathrm{~cm} ; 81.43 \mathrm{mbsf}(85.09 \mathrm{mcd})$. Categories 1, 2, and 4 contain a vector that trends toward the origin during demagnetization. The Category 3 vector veers into a plane perpendicular to the last demagnetization axis, which is a sign of gyroremanent magnetization acquisition. Open squares = vertical, solid squares $=$ horizontal.
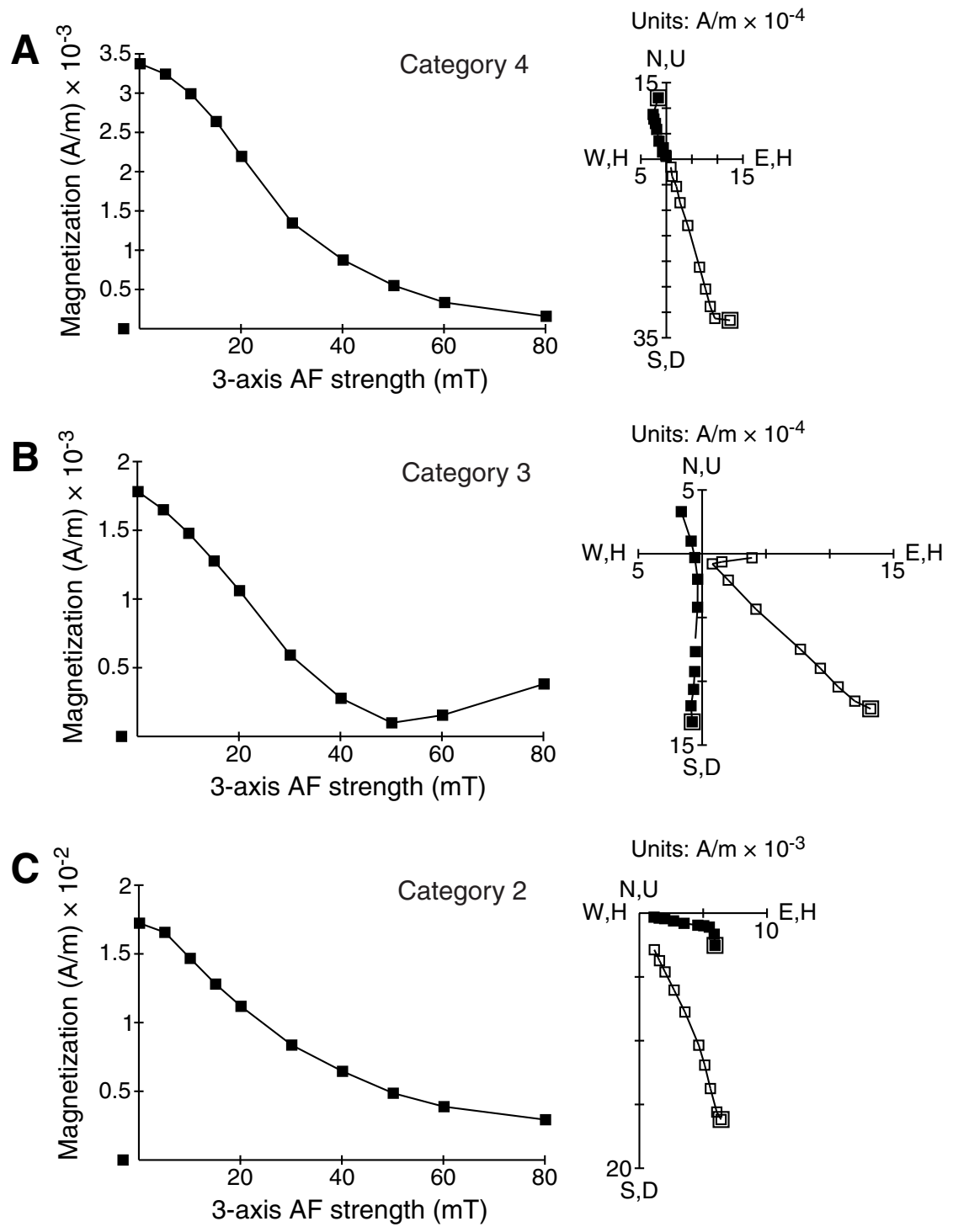

Units: $\mathrm{A} / \mathrm{m} \times 10^{-3}$
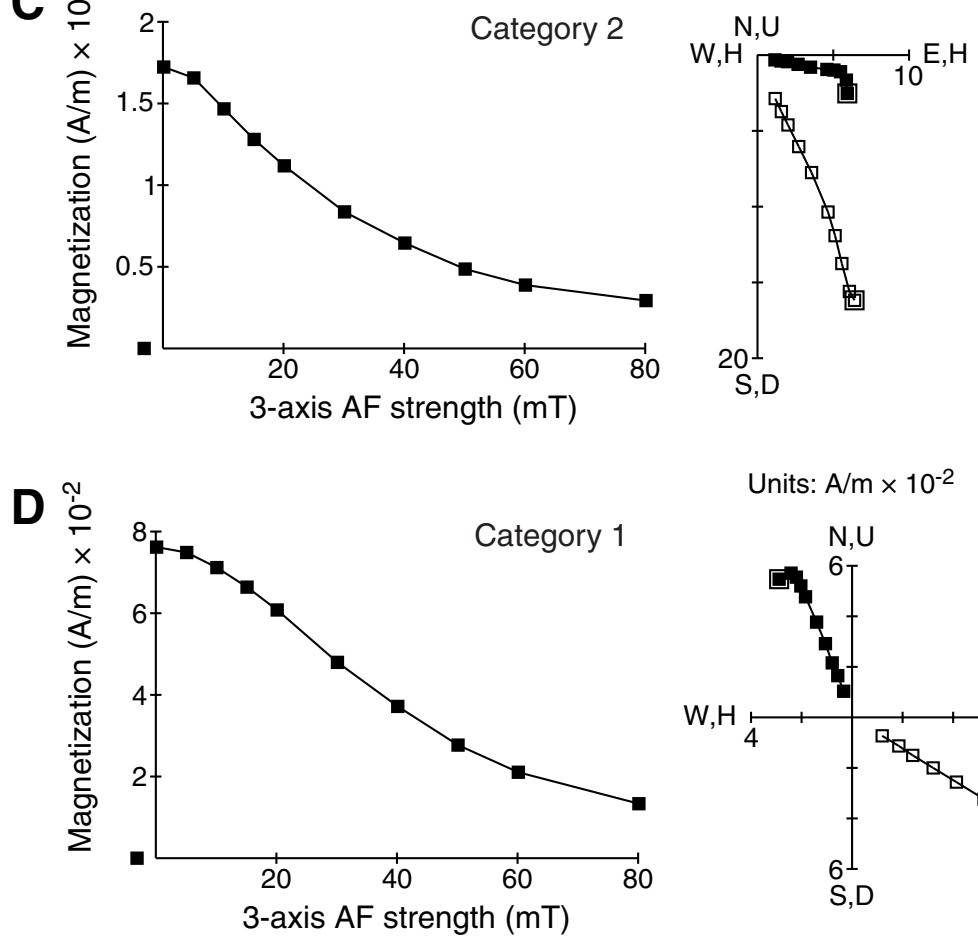

Units: $A / m \times 10^{-2}$

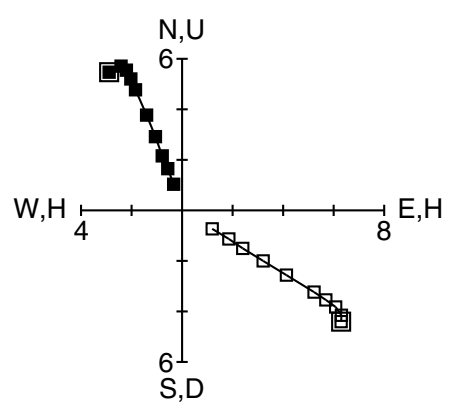


Figure F23. Plot of microbial cell abundances compared to chemical zonation and lithostratigraphy, Hole M0063E. A. Interstitial water alkalinity (blue dashed line) and salinity (red line). Green dashed line = depth below which both cell counting techniques yield similar results. B. Cell numbers obtained by flow cytometry (blue circles) and acridine orange direct count (red diamonds). Solid black line $=$ global regression line of prokaryote cell numbers with depth, dashed lines = upper and lower 95\% prediction limits for regression line (Roussel et al., 2008). Green dashed line $=$ depth below which both cell counting techniques yield similar results. C. Lithology.

A

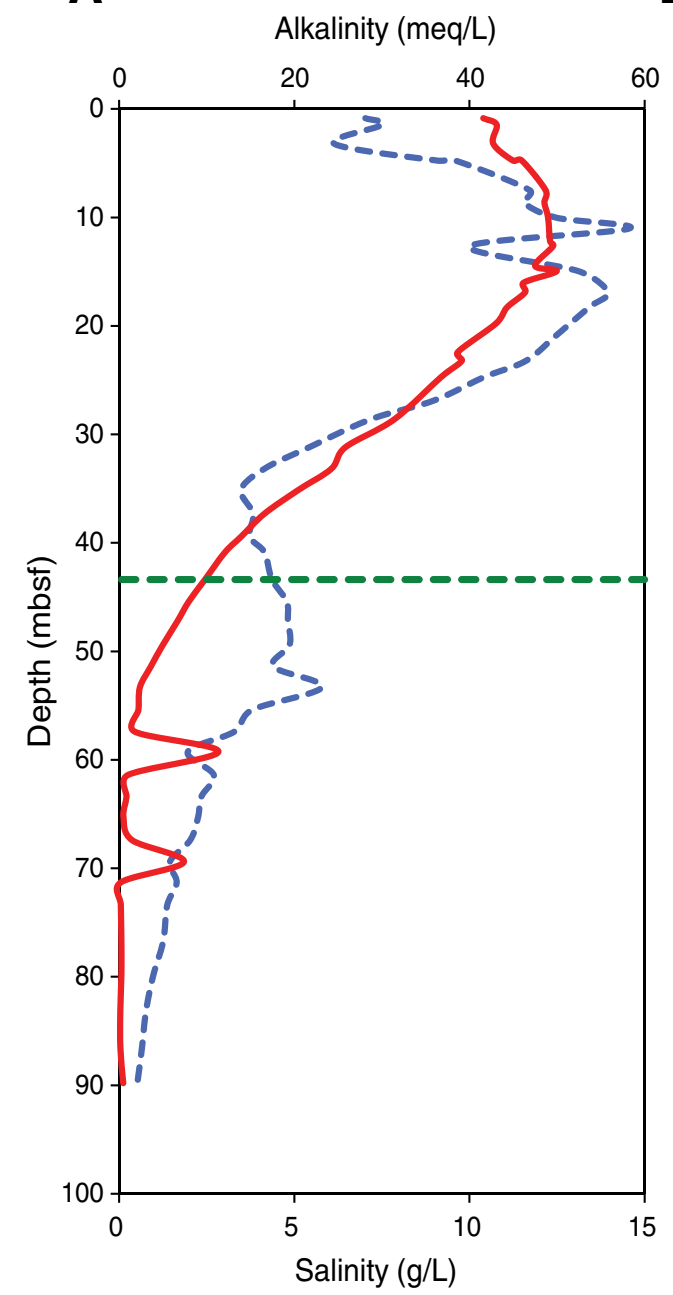

60
B

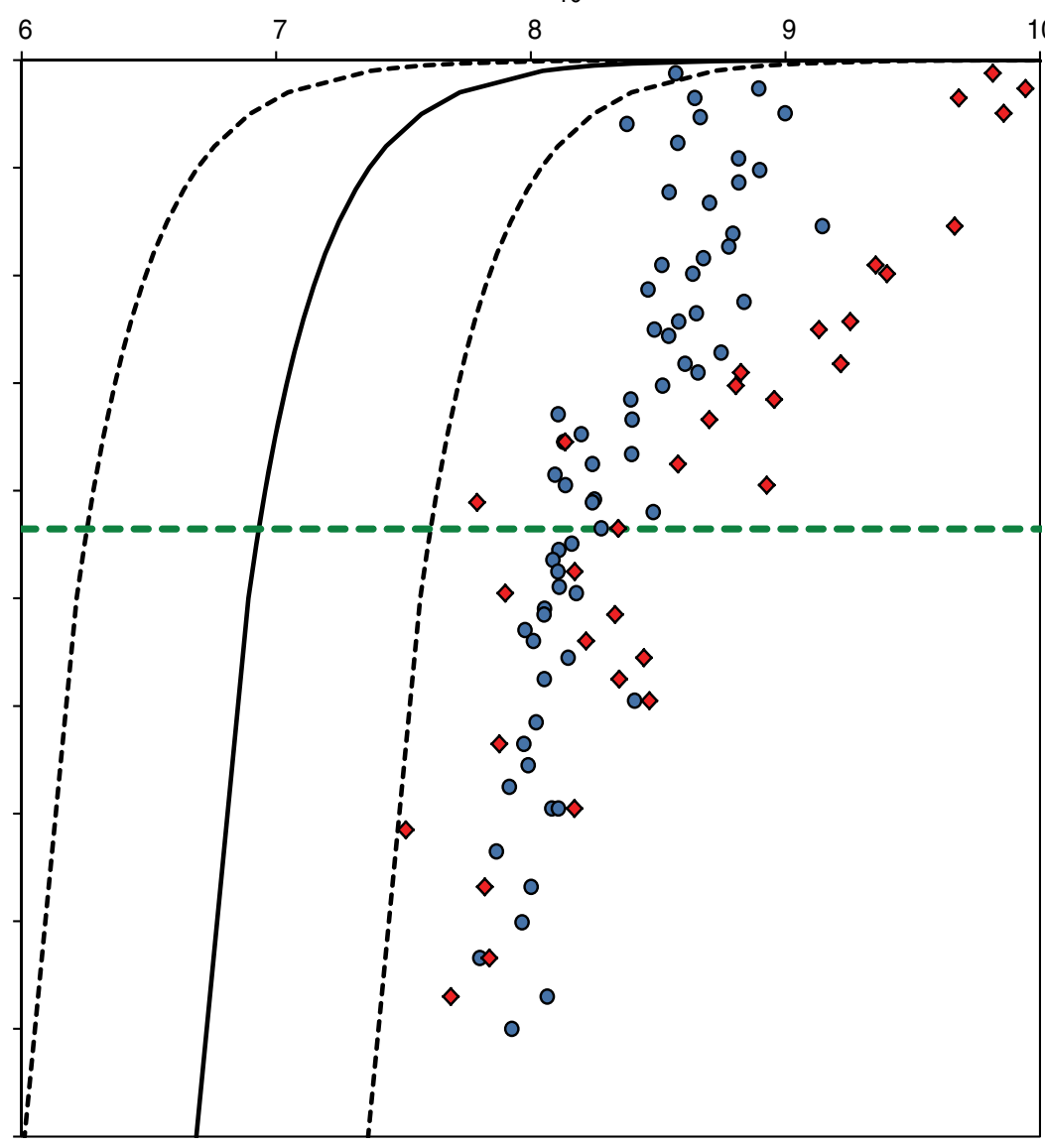

c

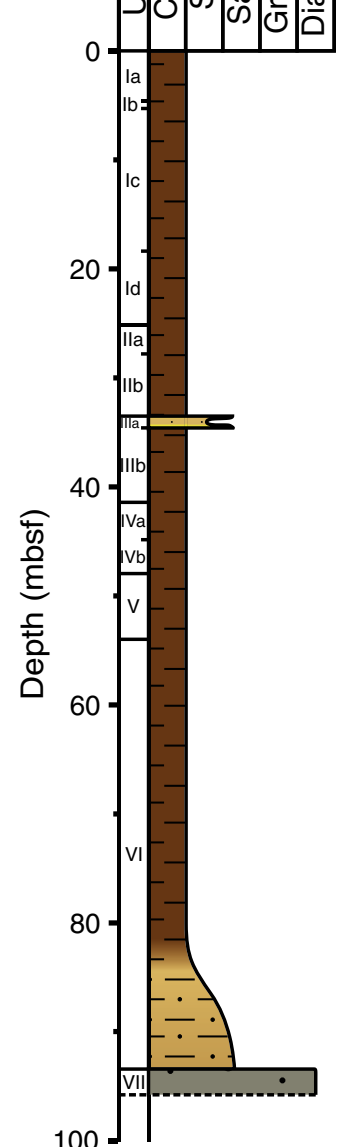



and sonicated. C. Stained, sonicated, and treated with hydrofluoric acid. Red arrows $=$ cell clumps, white arrows $=$ very small cells of $\sim 0.1 \mu \mathrm{m}$ diameter.

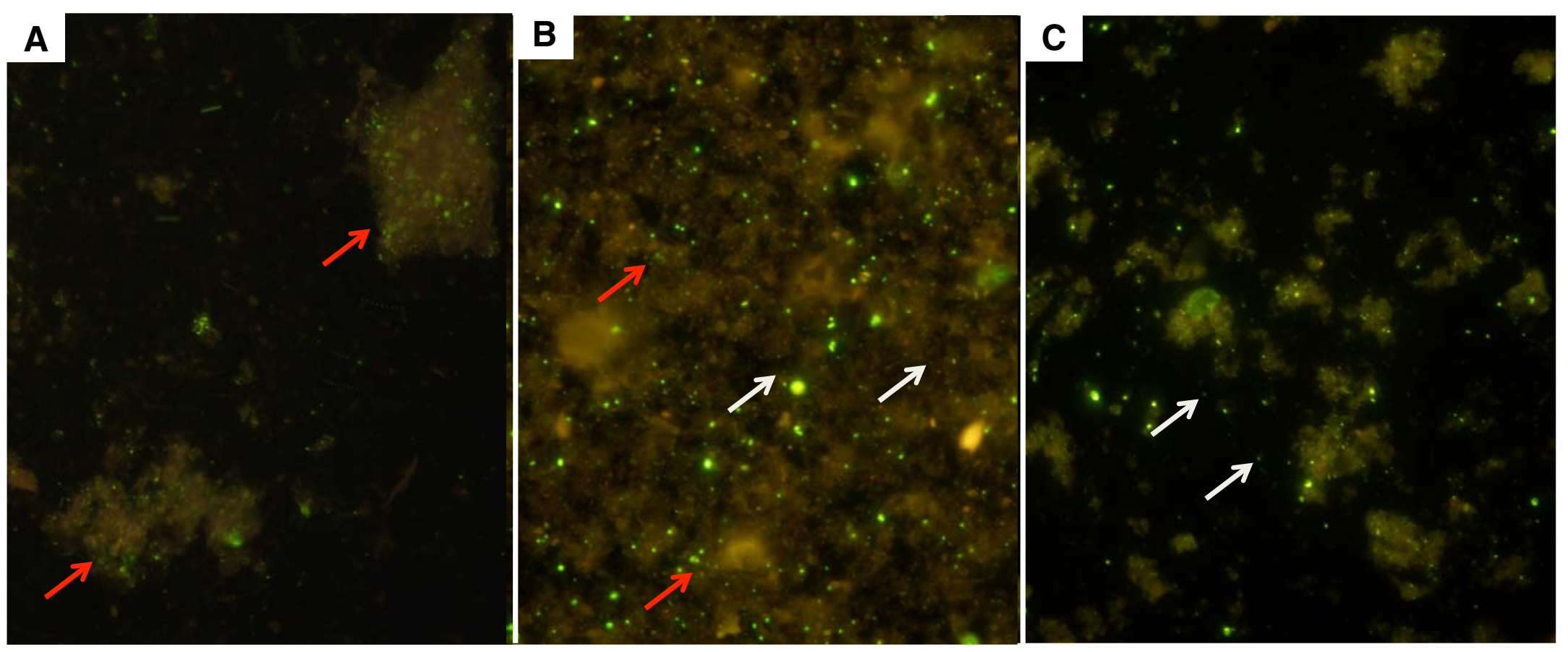


Figure F25. Comparison of paired counts between two methods of cell enumeration, Hole M0063E. Blue circles $=$ results from deeper than $43 \mathrm{mbsf}$, green squares = results from shallower than 43 mbsf. Black dashed line = line of unity. $\mathrm{FCM}=$ flow cytometry, $\mathrm{AODC}=$ acridine orange direct count.

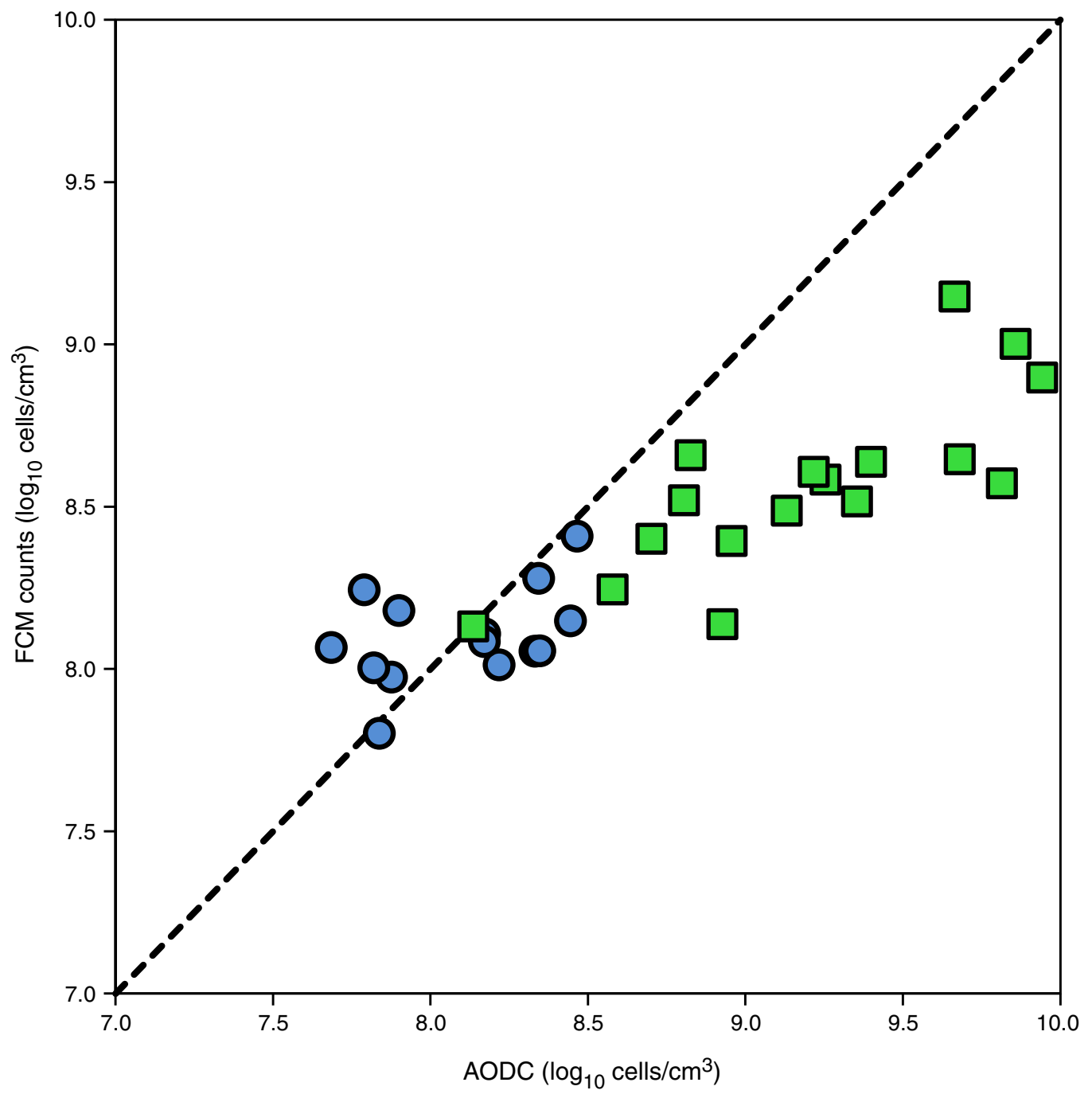


Figure F26. Plots of perfluorocarbon (PFC) tracer concentrations, Hole M0063E. A. Core liner fluid. B. Sediment core samples. (Continued on next page.)
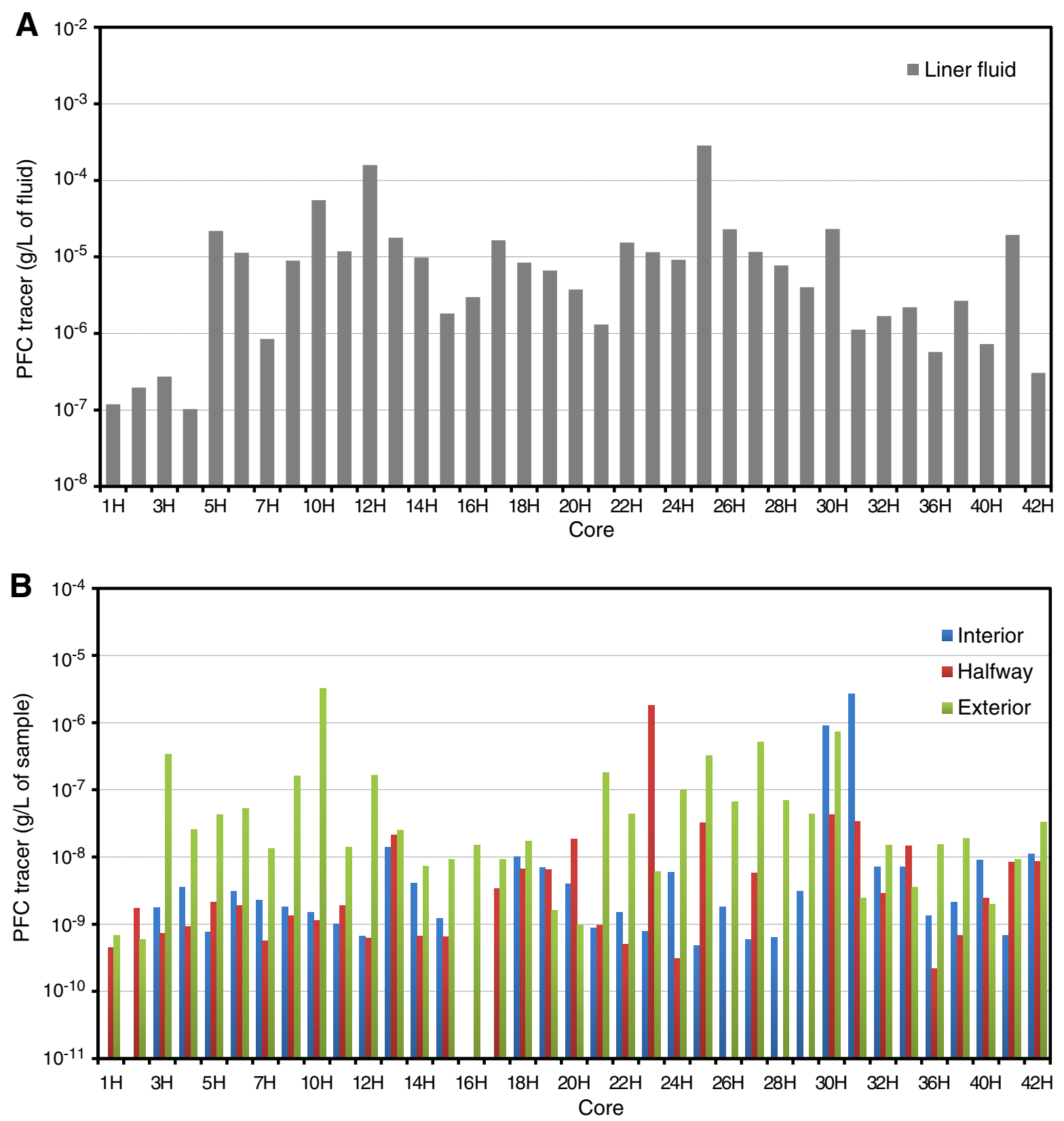
Figure F26 (continued). C. Estimated volume of liner fluid introduced into sediment cores shown as percentage of sediment core volume. D. Estimated potential number of contaminant cells per volume of sediment.
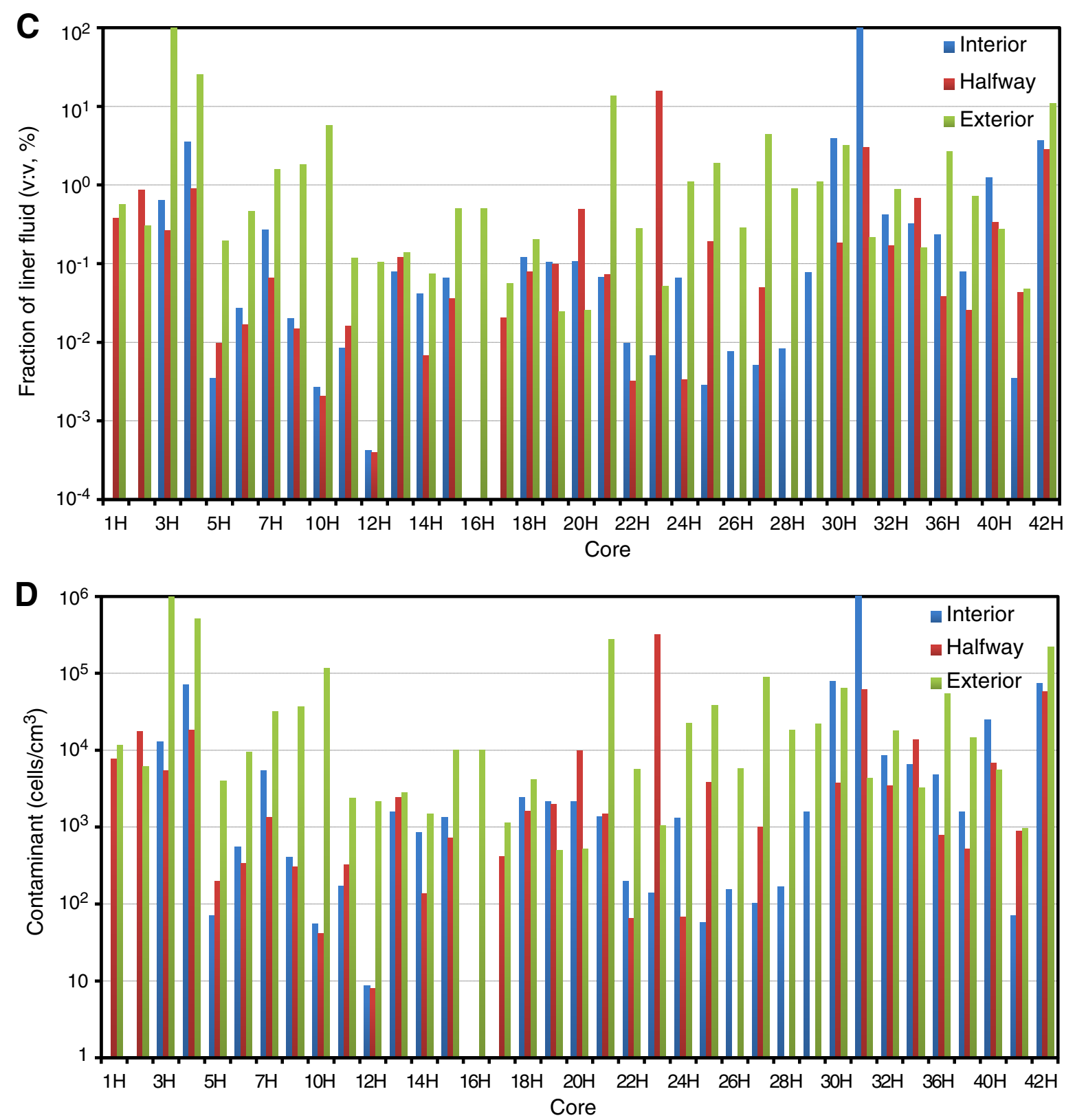
Figure F27. Examples of coring disturbances indicated by original, uncleaned magnetic susceptibility data, Hole M0063B.

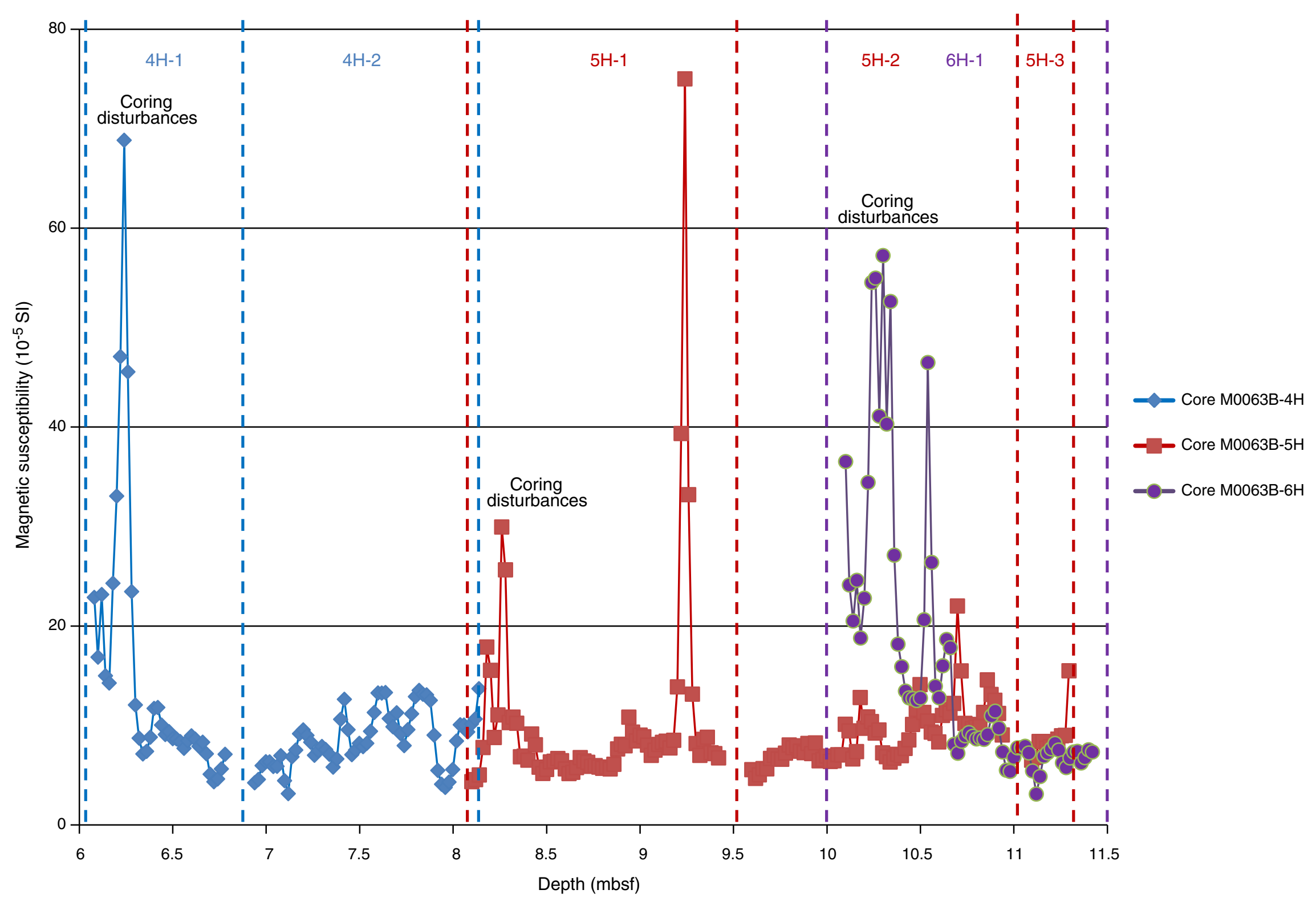


Figure F28. Comparison of downhole gamma ray and natural gamma ray measurements, Hole M0063A. Note that natural gamma ray values have been scaled by a factor of 10 and smoothed to enable comparison.

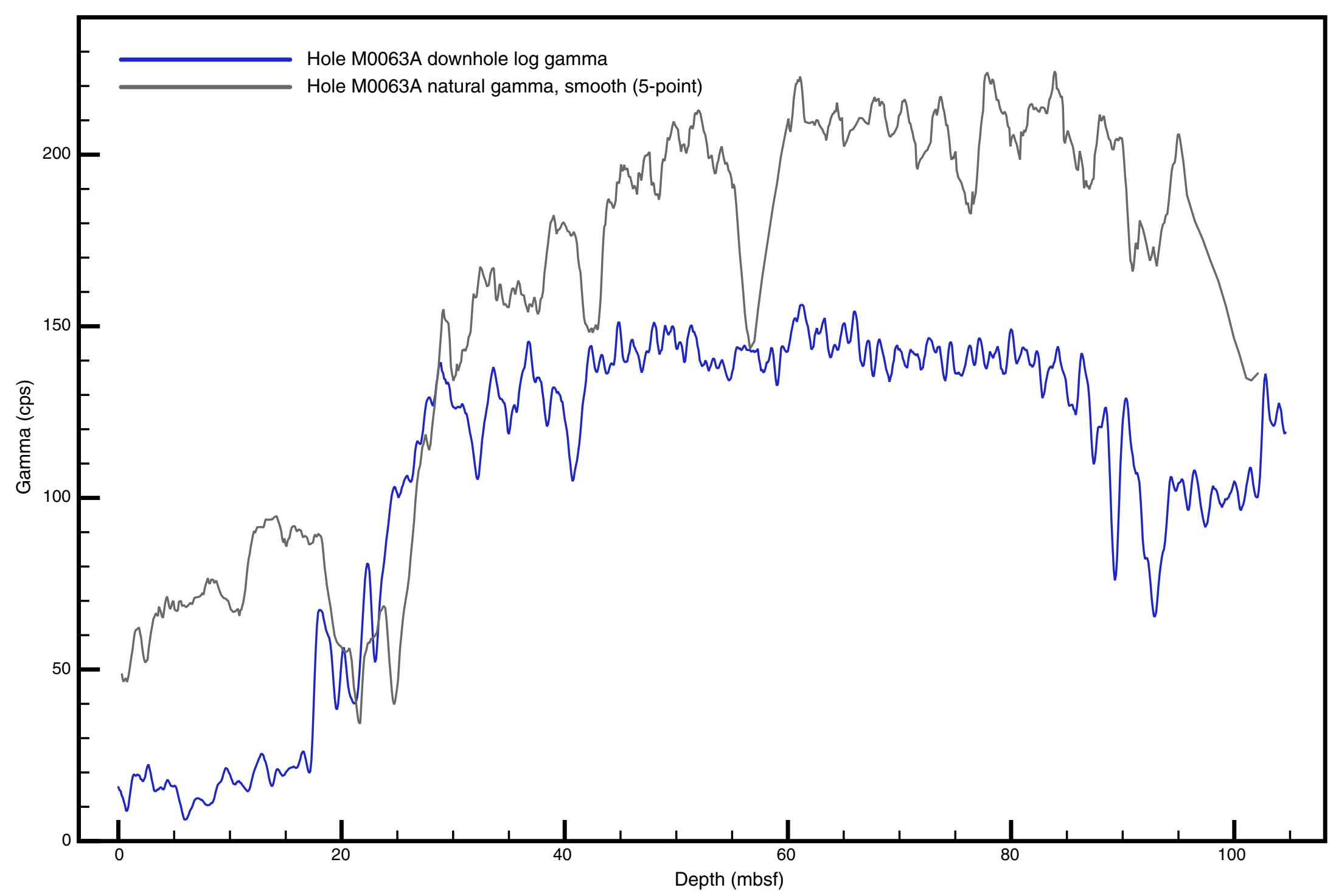


Figure F29. Correlation of the seismic profile with lithostratigraphic boundaries (seismic Units I-VII), Site M0063.

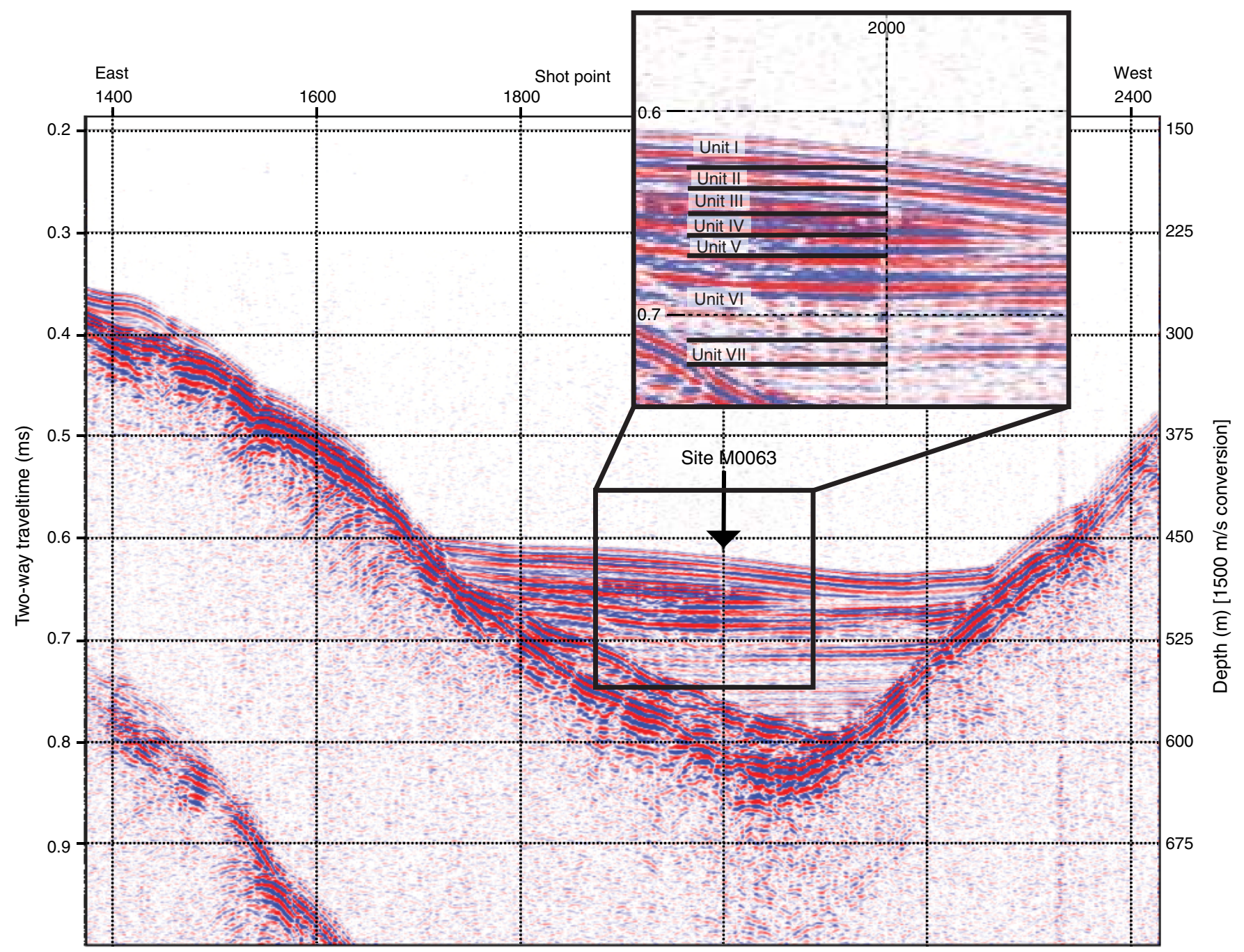


Figure F30. Caliper, gamma ray $\log$, spectral gamma ray $\log$, resistivity log, and sonic $\log$, Hole M0063A. The drill pipe is set at $17.5 \mathrm{~m}$ WSF.

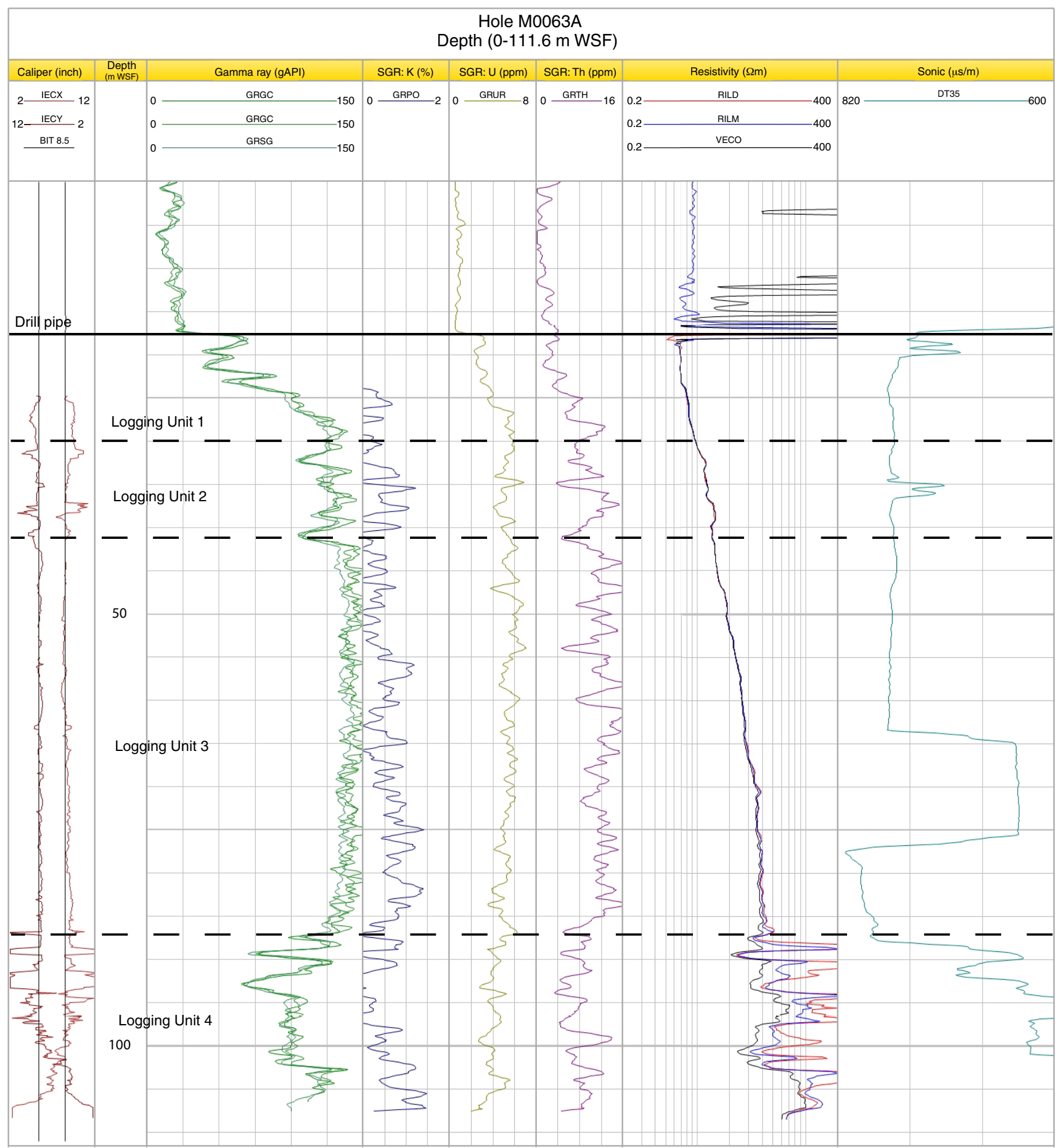


Table T1. Operations, Site M0063. (Continued on next five pages.)

\begin{tabular}{|c|c|c|c|c|c|c|c|c|c|}
\hline \multirow[b]{2}{*}{ Core } & \multirow{2}{*}{$\begin{array}{l}\text { Coring } \\
\text { method }\end{array}$} & \multirow{2}{*}{$\begin{array}{l}\text { Date } \\
(2013)\end{array}$} & \multirow{2}{*}{$\begin{array}{l}\text { Time } \\
\text { (UTC) }\end{array}$} & \multicolumn{2}{|c|}{ Depth (mbsf) } & \multirow{2}{*}{$\begin{array}{l}\text { Recovered } \\
(\mathrm{m})\end{array}$} & \multirow{2}{*}{$\begin{array}{l}\text { Recovery } \\
\quad(\%)\end{array}$} & \multirow[b]{2}{*}{ Mud type } & \multirow[b]{2}{*}{ Comments } \\
\hline & & & & Top & Bottom & & & & \\
\hline \multicolumn{10}{|c|}{ 347-M0063A- } \\
\hline & & 8 Oct & 0225 & & & & & & Arrived on location at Site M0063 \\
\hline & & 8 Oct & 0345 & & & & & & Steady on site; approval to run pipe given \\
\hline & & 8 Oct & 0400 & & & & & & Seabed template in the moonpool \\
\hline & & 8 Oct & 0450 & & & & & & Template on the seabed and was compensating \\
\hline & & 8 Oct & 0515 & & & & & & $4 \times$ collars on plus first API \\
\hline & & 8 Oct & 0945 & & & & & & $\begin{array}{l}20 \mathrm{~m} \text { discrepancy in water depth: template raised to touch string near the expected bottom; to determine how } \\
\text { many pipes to add; done because seabed might be too soft to notice when mudline is tagged }\end{array}$ \\
\hline & & 8 Oct & 1040 & & & & & & Lowered $1 \mathrm{~m}$ push sampler to determine how far above mudline the $\mathrm{BHA}$ is \\
\hline & & 8 Oct & 1043 & & & & & & Tool caught in string: pulled back and flush to clear \\
\hline $1 \mathrm{P}$ & PCA & 8 Oct & 1049 & 0.00 & 0.49 & 0.49 & 100 & Seawater & Very soft, black, aromatic mud recovered \\
\hline $2 \mathrm{H}$ & PCS & 8 Oct & 1120 & 0.00 & 3.30 & 3.97 & 120.3 & Seawater & Fired piston from calculated mudline (push sample filled back in to gap as it was so soft) \\
\hline $3 \mathrm{H}$ & PCS & 8 Oct & 1225 & 3.30 & 6.60 & 3.09 & 93.64 & Seawater & Had to hammer and use small amount of flush to release corer; overshot pins changed \\
\hline $4 \mathrm{H}$ & PCS & 8 Oct & 1325 & 6.60 & 9.90 & 2.70 & 81.82 & Seawater & Core squeezing into the lifting sub of the piston corer \\
\hline $5 \mathrm{H}$ & PCS & 8 Oct & 1435 & 9.90 & 13.20 & 3.15 & 95.45 & Seawater & \\
\hline $6 \mathrm{H}$ & PCS & 8 Oct & 1515 & 13.20 & 16.50 & 3.25 & 98.48 & Seawater & Core continued to fill liner and up into the top sub of corer \\
\hline 7H & PCS & 8 Oct & 1615 & 16.50 & 19.50 & 2.71 & 90.33 & Seawater & \\
\hline \multirow[t]{5}{*}{$8 \mathrm{H}$} & PCS & 8 Oct & 1715 & 19.50 & 22.80 & 3.70 & 112.12 & Seawater & Spline from the overshot "chaser/messenger" came off downhole; unsuccessful attempt to recover corer \\
\hline & & 8 Oct & 1930 & & & & & & $\begin{array}{l}\text { Deployed fishing tools including directional magnet; one attempt picked up corer but dropped it at a narrow } \\
\text { tool joint; spline fell faster than corer and both came together at a lower tool joint and jammed solid; despite } \\
\text { being able to grab the corer on a number of occasions, we were not able to free it and so tripped the pipe }\end{array}$ \\
\hline & & 8 Oct & 2130 & & & & & & Pulled pipe until stuck PC revealed \\
\hline & & 9 Oct & 0050 & & & & & & Ran pipe back in to template \\
\hline & & 9 Oct & 0253 & & & & & & Washed down to $22.8 \mathrm{mbsf}$ \\
\hline $9 \mathrm{H}$ & PCS & 9 Oct & 0323 & 22.80 & 26.10 & 3.57 & 108.18 & Seawater & $60 \mathrm{bar}$ \\
\hline \multirow{3}{*}{$10 \mathrm{H}$} & PCS & 9 Oct & 0510 & 26.10 & 29.40 & 3.70 & 112.12 & Seawater & \\
\hline & & 9 Oct & 0630 & & & & & & $\begin{array}{l}\text { Overshot release sleeve dropped out of slot on the way to recover the corer, jamming it in the string; prepared } \\
\text { to fish with magnet; } 2 \text { attempts failed }\end{array}$ \\
\hline & & 9 Oct & 0745 & & & & & & Wired 2 basket catchers into a Rumohr tube with magnet at top; successfully recovered spline on 2 nd attempt \\
\hline $11 \mathrm{H}$ & PCS & 9 Oct & 0815 & 29.40 & 32.70 & 3.42 & 103.64 & Seawater & Good clean fire; soft, expanding gray clay \\
\hline $12 \mathrm{H}$ & PCS & 9 Oct & 0930 & 32.70 & 36.00 & 3.60 & 109.09 & Seawater & \\
\hline $13 \mathrm{H}$ & PCS & 9 Oct & 1030 & 36.00 & 39.30 & 3.87 & 117.27 & Seawater & \\
\hline $14 \mathrm{H}$ & PCS & 9 Oct & 1115 & 39.30 & 42.60 & 3.97 & 120.3 & Seawater & $40 \mathrm{bar}$ \\
\hline $15 \mathrm{H}$ & PCS & 9 Oct & 1240 & 42.60 & 45.90 & 3.80 & 115.15 & Seawater & Slow build, possibly due to time taken to add pipe; blew at 40 bar \\
\hline \multirow[t]{2}{*}{$16 \mathrm{H}$} & PCS & 9 Oct & 1330 & 45.90 & 49.20 & 3.74 & 113.33 & Seawater & $40 \mathrm{bar}$ \\
\hline & & 9 Oct & 1400 & & & & & & $\begin{array}{l}\text { PCS could not be recovered from the BHA even after heavy pulling and back-hammering with a little mud } \\
\text { flush; after a lot of pulling and hammering, PCS recovered with a good core included }\end{array}$ \\
\hline $17 \mathrm{H}$ & PCS & 9 Oct & 1525 & 49.20 & 52.50 & 3.64 & 110.3 & Seawater & $70 \mathrm{bar}$ \\
\hline $18 \mathrm{H}$ & PCS & 9 Oct & 1635 & 52.50 & 55.80 & 3.36 & 101.82 & Seawater & \\
\hline $19 \mathrm{H}$ & PCS & 9 Oct & 1740 & 55.80 & 59.10 & 1.52 & 46.06 & Seawater & $\begin{array}{l}80 \text { bar to shear/good release; corer stuck; back-hammering/low-level pumping did not release; overshot } \\
\text { recovered to with pumping (mud valve closed); pressured string to } 40 \text { bar and blockage cleared, presumed } \\
\text { to be a seal; second deployment of overshot recovered corer; reduced recovery due to high-level pumping }\end{array}$ \\
\hline $20 \mathrm{H}$ & PCS & 9 Oct & 1920 & 59.10 & 62.40 & 3.69 & 111.82 & Seawater & Recovered first time \\
\hline $21 \mathrm{H}$ & PCS & 9 Oct & 2035 & 62.40 & 65.70 & 3.38 & 102.42 & Seawater & \\
\hline $22 \mathrm{H}$ & PCS & 9 Oct & 2145 & 65.70 & 69.00 & 3.70 & 112.12 & Seawater & $40 \mathrm{bar}$ \\
\hline $23 \mathrm{H}$ & PCS & 9 Oct & 2359 & 69.00 & 72.30 & 3.49 & 105.76 & Seawater & \\
\hline $24 \mathrm{H}$ & PCS & 10 Oct & 0108 & 72.30 & 75.60 & 3.52 & 106.67 & Seawater & \\
\hline $25 \mathrm{H}$ & PCS & 10 Oct & 0213 & 75.60 & 78.90 & 3.64 & 110.3 & Seawater & \\
\hline $26 \mathrm{H}$ & PCS & 10 Oct & 0350 & 78.90 & 82.20 & 3.42 & 103.64 & Seawater & \\
\hline $27 \mathrm{H}$ & PCS & 10 Oct & 0505 & 82.20 & 85.50 & 3.48 & 105.45 & Seawater & \\
\hline $28 \mathrm{H}$ & PCS & 10 Oct & 0625 & 85.50 & 88.80 & 3.55 & 107.58 & Seawater & \\
\hline
\end{tabular}


Table T1 (continued). (Continued on next page.)

\begin{tabular}{|c|c|c|c|c|c|c|c|c|c|}
\hline \multirow[b]{2}{*}{ Core } & \multirow{2}{*}{$\begin{array}{l}\text { Coring } \\
\text { method }\end{array}$} & \multirow{2}{*}{$\begin{array}{l}\text { Date } \\
(2013)\end{array}$} & \multirow{2}{*}{$\begin{array}{l}\text { Time } \\
\text { (UTC) }\end{array}$} & \multicolumn{2}{|c|}{ Depth (mbsf) } & \multirow{2}{*}{$\begin{array}{l}\text { Recovered } \\
(\mathrm{m})\end{array}$} & \multirow{2}{*}{$\begin{array}{l}\text { Recovery } \\
(\%)\end{array}$} & \multirow[b]{2}{*}{ Mud type } & \multirow[b]{2}{*}{ Comments } \\
\hline & & & & Top & Bottom & & & & \\
\hline $29 \mathrm{H}$ & PCS & 10 Oct & 0730 & 88.80 & 92.10 & 3.45 & 104.55 & Seawater & Good fire of 60 bar, slow to rise but fell in two steps to zero \\
\hline \multirow{3}{*}{$30 \mathrm{H}$} & PCS & 10 Oct & 0845 & 92.10 & 93.90 & 1.80 & 100 & Seawater & Good fire and cleared to zero \\
\hline & & 10 Oct & 0858 & & & & & & $\begin{array}{l}\text { Failed to recover corer; released overshot and recovered to allow pumping; still no release at second attempt; } \\
\text { again recovered overshot for further flushing; replaced overshot shear pins while circulating mud/water }\end{array}$ \\
\hline & & 10 Oct & 0928 & & & & & & $\begin{array}{l}\text { Reran overshot while circulating a small amount of water; pressure spike when connecting to the PCS but } \\
\text { successfully recovered this time; till }\end{array}$ \\
\hline $31 \mathrm{H}$ & PCS & 10 Oct & 0950 & 93.90 & 95.80 & 1.92 & 101.05 & Seawater & $\begin{array}{l}\text { Pressure up to } 100 \text { bar stopped by driller as no sign of firing point; on raising rooster box, pressure } \\
\text { immediately dropped to zero }\end{array}$ \\
\hline $32 x$ & ECS & 10 Oct & 1210 & 95.80 & 96.80 & 0.00 & 0 & Seawater & Switched to extended nose in an attempt to recover tills and advance faster than using the piston \\
\hline $33 x$ & ECS & 10 Oct & 1450 & 96.80 & 97.80 & 0.00 & 0 & Seawater & Corer could not be recovered, so 3 runs had to be made to clear the pipe sufficiently to get it back on deck \\
\hline 34P & PCA & 10 Oct & 1450 & 97.80 & 98.80 & 0.27 & 27 & Seawater & \\
\hline 350 & NCA & 10 Oct & 1515 & 98.80 & 101.80 & 0.00 & 0 & Seawater & \\
\hline \multirow{2}{*}{$36 \mathrm{P}$} & PCA & 10 Oct & 1545 & 101.80 & 102.80 & 0.66 & 66 & Seawater & Soft gray clay in shoe with disturbed sand above; attempted PCS next run \\
\hline & PCS & 10 Oct & 1610 & 102.80 & 102.80 & 0.00 & 0 & Seawater & Piston failed to penetrate sediment; attempted push sample from same depth \\
\hline $37 \mathrm{H}$ & PCS & 10 Oct & 1705 & 103.80 & 103.80 & 0.00 & 0 & Seawater & Full penetration: no recovery; trace of silty sand and gravel in barrel \\
\hline 380 & NCA & 10 Oct & 1750 & 103.80 & 105.80 & 0.00 & 0 & Seawater & Slow drilling, 1.5 metric tons on bit, no mud pressure; hint of red material on insert bit \\
\hline 395 & HS & 10 Oct & 1905 & 105.80 & 105.83 & 0.03 & 100 & & \\
\hline 400 & NCA & 10 Oct & 2015 & 105.83 & 115.80 & 0.00 & 0 & Seawater & $107.8 \mathrm{mbsf}$ at $2100 \mathrm{~h}$, slow drilling, 2 metric tons on bit; much backfall; pink till on insert bit \\
\hline \multirow[t]{10}{*}{415} & HS & 11 Oct & 0100 & 115.80 & 115.81 & 0.01 & 100 & & \\
\hline & & 11 Oct & 0150 & & & & & & Started to pull pipe and prepare hole for logging \\
\hline & & 11 Oct & 0320 & & & & & & Ready to run first log \\
\hline & & 11 Oct & 0430 & & & & & & First logging back on deck, reached $108 \mathrm{mbsf}$ \\
\hline & & 11 Oct & 0447 & & & & & & Second logging string running downhole \\
\hline & & 11 Oct & 0503 & & & & & & Second log completed and on deck \\
\hline & & 11 Oct & 0522 & & & & & & Third logging string going downhole \\
\hline & & 11 Oct & 0700 & & & & & & Logging complete \\
\hline & & 11 Oct & 0723 & & & & & & All logging equipment off deck \\
\hline & & & & & & & & & Prepared and tripped pipe to above seabed for bump over to Hole M0063B \\
\hline \multicolumn{10}{|c|}{ 347-M0063B- } \\
\hline & & 11 Oct & 0850 & & & & & & Completed bumping over operation; seabed frame above seabed until first sample collected \\
\hline & & & & & & & & & $\begin{array}{l}\text { Coring strategy: collect } 2 \mathrm{~m} \text { of sediment per fire to allow core expansion in } 3.3 \mathrm{~m} \text { liner; pull back } 1.3 \mathrm{~m} \text { from } \\
\text { the base of each washed out interval before pressurizing string; advance BHA } 2 \mathrm{~m} \text { after PCS sample run }\end{array}$ \\
\hline \multirow[t]{2}{*}{$1 \mathrm{H}$} & PCS & 11 Oct & 0910 & 0.00 & 2.00 & 1.52 & 76 & Seawater & PCS kept $\sim 1.3 \mathrm{~m}$ above seabed to allow $2 \mathrm{~m}$ core to be taken with room for expansion of gaseous sediment \\
\hline & & 11 Oct & 0940 & & & & & & Unable to release PCS, so recovered overshot to allow flushing; successful second attempt \\
\hline $2 \mathrm{H}$ & PCS & 11 Oct & 0910 & 2.00 & 4.00 & 3.52 & 176 & Seawater & \\
\hline $3 \mathrm{H}$ & PCS & 11 Oct & 1220 & 4.00 & 6.00 & 2.61 & 130.5 & Seawater & \\
\hline $4 \mathrm{H}$ & PCS & 11 Oct & 1300 & 6.00 & 8.00 & 2.34 & 117 & Seawater & \\
\hline $5 \mathrm{H}$ & PCS & 11 Oct & 1350 & 8.00 & 10.00 & 3.50 & 175 & Seawater & \\
\hline $6 \mathrm{H}$ & PCS & $11 \mathrm{Oct}$ & 1455 & 10.00 & 12.00 & 2.61 & 130.5 & Seawater & \\
\hline $7 \mathrm{H}$ & PCS & 11 Oct & 1555 & 12.00 & 15.00 & 3.60 & 120 & Seawater & \\
\hline $8 \mathrm{H}$ & PCS & 11 Oct & 1640 & 15.00 & 17.00 & 3.16 & 158 & Seawater & \\
\hline $9 \mathrm{H}$ & PCS & $11 \mathrm{Oct}$ & 1740 & 17.00 & 19.00 & 2.50 & 125 & Seawater & \\
\hline $10 \mathrm{H}$ & PCS & 11 Oct & 1825 & 19.00 & 21.00 & 2.64 & 132 & Seawater & \\
\hline $11 \mathrm{H}$ & PCS & 11 Oct & 1900 & 21.00 & 23.00 & 3.45 & 172.5 & Seawater & \\
\hline $12 \mathrm{H}$ & PCS & $11 \mathrm{Oct}$ & 2000 & 23.00 & 25.00 & 3.27 & 163.5 & Seawater & \\
\hline $13 \mathrm{H}$ & PCS & 11 Oct & 2055 & 25.00 & 27.00 & 3.10 & 155 & Seawater & \\
\hline \multirow[t]{5}{*}{$14 \mathrm{H}$} & PCS & 11 Oct & 2140 & 27.00 & 29.00 & 2.85 & 142.5 & Seawater & \\
\hline & & 11 Oct & 2230 & & & & & & End of Hole M0063B; started lifting pipe \\
\hline & & 12 Oct & 0052 & & & & & & At start of drill collars \\
\hline & & 12 Oct & 0330 & & & & & & Seabed frame to below deck \\
\hline & & 12 Oct & 0355 & & & & & & BHA removed and seabed frame secured on deck \\
\hline
\end{tabular}


Table T1 (continued). (Continued on next page.)

\begin{tabular}{|c|c|c|c|c|c|c|c|c|c|}
\hline \multirow{2}{*}{ Core } & \multirow{2}{*}{$\begin{array}{l}\text { Coring } \\
\text { method }\end{array}$} & \multirow{2}{*}{$\begin{array}{l}\text { Date } \\
\text { (2013) }\end{array}$} & \multirow{2}{*}{$\begin{array}{l}\text { Time } \\
\text { (UTC) }\end{array}$} & \multicolumn{2}{|c|}{ Depth (mbsf) } & \multirow{2}{*}{$\begin{array}{l}\text { - Recovered } \\
(\mathrm{m})\end{array}$} & \multirow{2}{*}{$\begin{array}{l}\text { Recovery } \\
\text { (\%) }\end{array}$} & \multirow[b]{2}{*}{ Mud type } & \multirow[b]{2}{*}{ Comments } \\
\hline & & & & Top & Bottom & & & & \\
\hline \multicolumn{10}{|c|}{ 347-M0063C- } \\
\hline & & 12 Oct & 2115 & & & & & & Fitted transponder and lowered seabed template into the moonpool \\
\hline & & 12 Oct & 2125 & & & & & & Connected BHA \\
\hline & & 12 Oct & 2255 & & & & & & Lowered seabed template to $\sim 428 \mathrm{~m}$ \\
\hline & & 12 Oct & 2315 & & & & & & Finished repairs to torque twister and lowered drill pipe \\
\hline & & 13 Oct & 0215 & & & & & & All collars on \\
\hline & & 13 Oct & 0229 & & & & & & Bit $1.3 \mathrm{~m}$ above seafloor \\
\hline $1 \mathrm{H}$ & PCS & 13 Oct & 0330 & 0.00 & 2.00 & 3.71 & 185.5 & Seawater & Shot from $1.3 \mathrm{~m}$ above seabed; lowered seabed template to seabed \\
\hline $2 \mathrm{H}$ & PCS & 13 Oct & 0430 & 2.00 & 4.00 & 3.12 & 156 & Seawater & $70 \mathrm{bar}$ \\
\hline $3 \mathrm{H}$ & PCS & 13 Oct & 0530 & 4.00 & 6.00 & 2.50 & 125 & Seawater & Strong $\mathrm{H}_{2} \mathrm{~S}$ smell and $>50 \%$ expansion of core \\
\hline $4 \mathrm{H}$ & PCS & 13 Oct & 0620 & 6.00 & 8.00 & 2.24 & 112 & Seawater & Not as explosive as last run \\
\hline $5 \mathrm{H}$ & PCS & 13 Oct & 0705 & 8.00 & 10.00 & 3.02 & 151 & Seawater & \\
\hline $6 \mathrm{H}$ & PCS & 13 Oct & 0750 & 10.00 & 12.00 & 2.44 & 122 & Seawater & \\
\hline 7H & PCS & 13 Oct & 0855 & 12.00 & 14.00 & 2.66 & 133 & Seawater & Took some time to pressure up; pipe change \\
\hline $8 \mathrm{H}$ & PCS & 13 Oct & 0955 & 14.00 & 16.00 & 2.51 & 125.5 & Seawater & \\
\hline $9 \mathrm{H}$ & PCS & 13 Oct & 1050 & 16.00 & 18.00 & 2.61 & 130.5 & Seawater & $68 \mathrm{bar}$ \\
\hline $10 \mathrm{H}$ & PCS & 13 Oct & 1135 & 18.00 & 20.00 & 2.60 & 130 & Seawater & $68 \mathrm{bar}$ \\
\hline $11 \mathrm{H}$ & PCS & 13 Oct & 1225 & 20.00 & 22.00 & 2.64 & 132 & Seawater & New style seal fired at only 10 bar and seal lost \\
\hline $12 \mathrm{H}$ & PCS & 13 Oct & 1345 & 22.00 & 24.00 & 2.68 & 134 & Seawater & Lost seal and stuck corer; recovered overshot and flushed with mud to clear \\
\hline $13 \mathrm{H}$ & PCS & 13 Oct & 1440 & 24.00 & 26.00 & 3.23 & 161.5 & Seawater & Single new seal, old spacers \\
\hline $14 \mathrm{H}$ & PCS & 13 Oct & 1520 & 26.00 & 28.00 & 2.79 & 139.5 & Seawater & \\
\hline $15 \mathrm{H}$ & PCS & 13 Oct & 1625 & 28.00 & 30.00 & 2.94 & 147 & Seawater & \\
\hline $16 \mathrm{H}$ & PCS & 13 Oct & 1715 & 30.00 & 32.00 & 3.00 & 150 & Seawater & \\
\hline $17 \mathrm{H}$ & PCS & 13 Oct & 1810 & 32.00 & 34.00 & 3.68 & 184 & Seawater & \\
\hline $18 \mathrm{H}$ & PCS & $13 \mathrm{Oct}$ & 1900 & 34.00 & 36.00 & 3.64 & 182 & Seawater & \\
\hline $19 \mathrm{H}$ & PCS & 13 Oct & 1943 & 36.00 & 38.00 & 2.90 & 145 & Seawater & \\
\hline $20 \mathrm{H}$ & PCS & $13 \mathrm{Oct}$ & 2039 & 38.00 & 40.00 & 3.36 & 168 & Seawater & \\
\hline $21 \mathrm{H}$ & PCS & $13 \mathrm{Oct}$ & 2130 & 40.00 & 42.00 & 3.34 & 167 & Seawater & \\
\hline $22 \mathrm{H}$ & PCS & 13 Oct & 2328 & 42.00 & 44.00 & 3.48 & 174 & Seawater & Backflow in pipe when preparing core barrel, so pump clear for a bit \\
\hline $23 \mathrm{H}$ & PCS & 14 Oct & 0027 & 44.00 & 46.00 & 3.05 & 152.5 & Seawater & Fired at $80 \mathrm{bar}$; kept pressure for longer but reduced to zero \\
\hline $24 \mathrm{H}$ & PCS & 14 Oct & 0124 & 46.00 & 48.00 & 2.91 & 145.5 & Seawater & \\
\hline $25 \mathrm{H}$ & PCS & 14 Oct & 0220 & 48.00 & 50.00 & 3.08 & 154 & Seawater & \\
\hline $26 \mathrm{H}$ & PCS & 14 Oct & 0313 & 50.00 & 52.00 & 2.86 & 143 & Seawater & Less expansion noted; increased core run to $2.5 \mathrm{~m}$ \\
\hline $27 \mathrm{H}$ & PCS & 14 Oct & 0445 & 52.00 & 54.50 & 2.81 & 112.4 & Seawater & Good core, little expansion; attempted $3.3 \mathrm{~m}$ core next time \\
\hline $28 \mathrm{H}$ & PCS & 14 Oct & 0545 & 54.50 & 57.80 & 2.64 & 80 & Seawater & \\
\hline $29 \mathrm{H}$ & PCS & 14 Oct & 0630 & 57.80 & 61.10 & 3.38 & 102.42 & Seawater & \\
\hline $30 \mathrm{H}$ & PCS & 14 Oct & 0720 & 61.10 & 64.40 & 3.44 & 104.24 & Seawater & \\
\hline $31 \mathrm{H}$ & PCS & 14 Oct & 0815 & 64.40 & 67.70 & 3.55 & 107.58 & Seawater & \\
\hline $32 \mathrm{H}$ & PCS & 14 Oct & 0910 & 67.70 & 71.00 & 3.54 & 107.27 & Seawater & \\
\hline $33 \mathrm{H}$ & PCS & 14 Oct & 1010 & 71.00 & 74.30 & 3.54 & 107.27 & Seawater & \\
\hline $34 \mathrm{H}$ & PCS & 14 Oct & 1105 & 74.30 & 77.60 & 3.67 & 111.21 & Seawater & \\
\hline $35 \mathrm{H}$ & PCS & $14 \mathrm{Oct}$ & 1150 & 77.60 & 80.90 & 3.47 & 105.15 & Seawater & \\
\hline $36 \mathrm{H}$ & PCS & 14 Oct & 1245 & 80.90 & 84.20 & 3.45 & 104.55 & Seawater & \\
\hline $37 \mathrm{H}$ & PCS & 14 Oct & 1335 & 84.20 & 87.50 & 3.51 & 106.36 & Seawater & \\
\hline $38 \mathrm{H}$ & PCS & 14 Oct & 1435 & 87.50 & 90.80 & 3.46 & 104.85 & Guar & \\
\hline $39 \mathrm{H}$ & PCS & 14 Oct & 1539 & 90.80 & 93.30 & 2.50 & 100 & Guar & \\
\hline 400 & NCA & 14 Oct & 1645 & 93.30 & 96.30 & 0.00 & 0 & Guar & \\
\hline \multirow[t]{3}{*}{$41 \mathrm{~S}$} & HS & 14 Oct & 1720 & 96.30 & 96.40 & 0.10 & 100 & Guar & \\
\hline & & & & & & & & & Pulled pipes \\
\hline & & & & & & & & & Seabed template off seafloor; bump over to Hole M0063D \\
\hline
\end{tabular}


Table T1 (continued). (Continued on next page.)

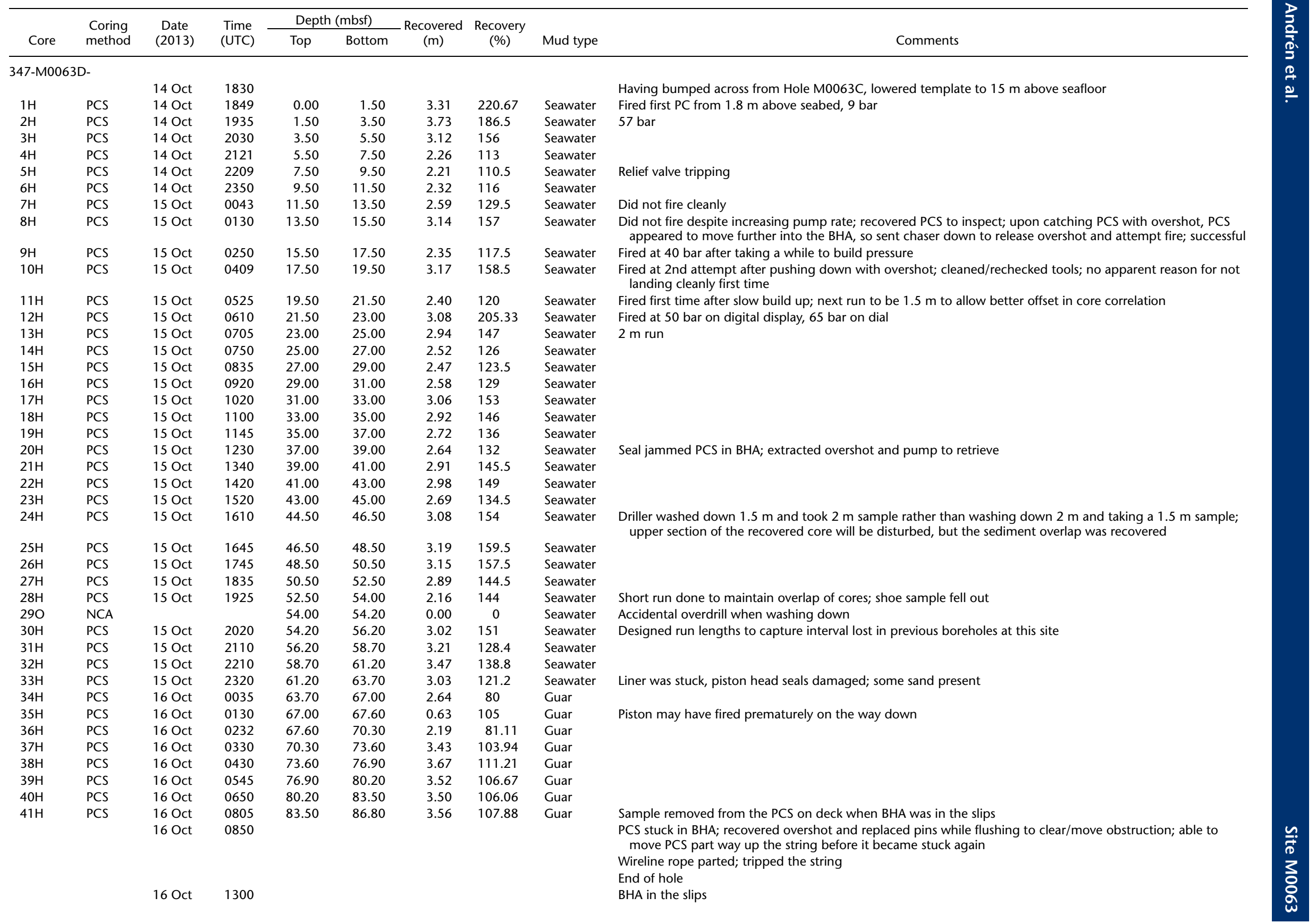


Table T1 (continued). (Continued on next page.)

\begin{tabular}{|c|c|c|c|c|c|c|c|c|c|}
\hline \multirow[b]{2}{*}{ Core } & \multirow{2}{*}{$\begin{array}{l}\text { Coring } \\
\text { method }\end{array}$} & \multirow{2}{*}{$\begin{array}{l}\text { Date } \\
(2013)\end{array}$} & \multirow{2}{*}{$\begin{array}{l}\text { Time } \\
\text { (UTC) }\end{array}$} & \multicolumn{2}{|c|}{ Depth (mbsf) } & \multirow{2}{*}{$\begin{array}{l}\text { Recovered } \\
(\mathrm{m})\end{array}$} & \multirow{2}{*}{$\begin{array}{l}\text { Recovery } \\
(\%)\end{array}$} & \multirow[b]{2}{*}{ Mud type } & \multirow[b]{2}{*}{ Comments } \\
\hline & & & & Top & Bottom & & & & \\
\hline & & & & & & & & & $\begin{array}{l}\text { Attempted to extract PCS from BHA without success, stuck fast; backed off top two joints to access possible } \\
\text { blockage; joints only came partially open before becoming tight, so this operation stopped }\end{array}$ \\
\hline & & & & & & & & & $\begin{array}{l}\text { Lifted BHA above deck to check for bend outside bit; no bend; extracted good sample from shoe; added spacer } \\
\text { to barrel to allow movement of tube in BHA; backed off PCS barrel at quick release while still in BHA }\end{array}$ \\
\hline & & 16 Oct & 1430 & & & & & & $\begin{array}{l}\text { Split BHA at stabilizer sub to view PCS head: discover rolled-over seal still in groove; cut and removed same; } \\
\text { lowered BHA into the slips and removed piston rod with overshot in the conventional manner }\end{array}$ \\
\hline & & 16 Oct & 1530 & & & & & & Placed BHA on deck to torque with Scorpion \\
\hline & & $16 \mathrm{Oct}$ & 1845 & & & & & & $\begin{array}{l}\text { Could not torque top subs in slips; decided to switch out BHAs and use last remaining spare } \\
\text { Bumping over }\end{array}$ \\
\hline \multicolumn{10}{|c|}{ 347-M0063E- } \\
\hline & & 16 Oct & 2020 & & & & & & Running pipe (BHA in slips) \\
\hline & & 16 Oct & 2100 & & & & & & All collars on \\
\hline & & 16 Oct & 2340 & & & & & & Bit at $1.3 \mathrm{~m}$ above seabed \\
\hline $1 \mathrm{H}$ & PCS & 16 Oct & 2355 & 0.00 & 2.00 & 2.80 & 140 & Seawater & Fired at $1.3 \mathrm{~m}$ above seabed, $15 \mathrm{bar}$ \\
\hline \multirow[t]{2}{*}{$2 \mathrm{H}$} & PCS & 17 Oct & 0140 & 2.00 & 4.00 & 3.49 & 174.5 & Seawater & $57 \mathrm{bar}$ \\
\hline & & 17 Oct & 0205 & & & & & & Lowered seabed frame onto seafloor \\
\hline $3 \mathrm{H}$ & PCS & 17 Oct & 0303 & 4.00 & 6.00 & 2.25 & 112.5 & Seawater & \\
\hline $4 \mathrm{H}$ & PCS & 17 Oct & 0500 & 6.00 & 8.00 & 2.24 & 112 & Seawater & \\
\hline $5 \mathrm{H}$ & PCS & 17 Oct & 0555 & 8.00 & 10.00 & 2.70 & 135 & Seawater & \\
\hline $6 \mathrm{H}$ & PCS & 17 Oct & 0655 & 10.00 & 12.00 & 2.71 & 135.5 & Seawater & \\
\hline $7 \mathrm{H}$ & PCS & 17 Oct & 0750 & 12.00 & 14.00 & 2.84 & 142 & Seawater & \\
\hline $8 \mathrm{H}$ & PCS & 17 Oct & 0845 & 14.00 & 16.00 & 2.31 & 115.5 & Seawater & \\
\hline $9 \mathrm{H}$ & PCS & 17 Oct & 0930 & 16.00 & 18.00 & 2.74 & 137 & Seawater & \\
\hline $10 \mathrm{H}$ & PCS & 17 Oct & 1050 & 18.00 & 20.00 & 2.09 & 104.5 & Seawater & \\
\hline $11 \mathrm{H}$ & PCS & 17 Oct & 1155 & 20.00 & 22.00 & 2.65 & 132.5 & Seawater & \\
\hline $12 \mathrm{H}$ & PCS & 17 Oct & 1255 & 22.00 & 24.00 & 2.63 & 131.5 & Seawater & \\
\hline $13 \mathrm{H}$ & PCS & 17 Oct & 1350 & 24.00 & 26.00 & 1.88 & 94 & Seawater & $12 \mathrm{bar}$ \\
\hline $14 \mathrm{H}$ & PCS & 17 Oct & 1455 & 26.00 & 28.00 & 2.52 & 126 & Seawater & 13 bar; changed seal next run \\
\hline $15 \mathrm{H}$ & PCS & 17 Oct & 1555 & 28.00 & 30.00 & 2.63 & 131.5 & Seawater & \\
\hline $16 \mathrm{H}$ & PCS & 17 Oct & 1630 & 30.00 & 32.00 & 3.45 & 172.5 & Seawater & \\
\hline $17 \mathrm{H}$ & PCS & 17 Oct & 1735 & 32.00 & 34.00 & 3.71 & 185.5 & Seawater & Did not fire; recovered to check, no problems obvious so changed pins and sent it back down; fired at $68 \mathrm{bar}$ \\
\hline $18 \mathrm{H}$ & PCS & 17 Oct & 1940 & 34.00 & 36.00 & 3.35 & 167.5 & Seawater & 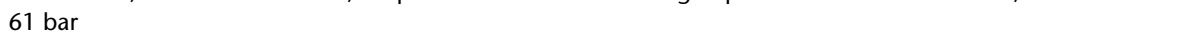 \\
\hline $19 \mathrm{H}$ & PCS & 17 Oct & 2035 & 36.00 & 38.00 & 2.82 & 141 & Seawater & $54 \mathrm{bar}$ \\
\hline $2 \mathrm{OH}$ & PCS & 17 Oct & 2140 & 38.00 & 40.00 & 3.10 & 155 & Seawater & $13 \mathrm{bar}$ \\
\hline $21 \mathrm{H}$ & PCS & 17 Oct & 2253 & 40.00 & 42.00 & 2.60 & 130 & Seawater & $45 \mathrm{bar}$ \\
\hline $22 \mathrm{H}$ & PCS & 17 Oct & 2345 & 42.00 & 44.00 & 3.20 & 160 & Seawater & $45 \mathrm{bar}$ \\
\hline $23 \mathrm{H}$ & PCS & 18 Oct & 0048 & 44.00 & 46.00 & 2.72 & 136 & Seawater & $45 \mathrm{bar}$ \\
\hline $24 \mathrm{H}$ & PCS & $18 \mathrm{Oct}$ & 0145 & 46.00 & 48.00 & 3.31 & 165.5 & Seawater & $15 \mathrm{bar}$ \\
\hline $25 \mathrm{H}$ & PCS & 18 Oct & 0237 & 48.00 & 50.00 & 3.39 & 169.5 & Seawater & $45 \mathrm{bar}$ \\
\hline $26 \mathrm{H}$ & PCS & 18 Oct & 0334 & 50.00 & 52.00 & 3.39 & 169.5 & Seawater & $73 \mathrm{bar}$ \\
\hline $27 \mathrm{H}$ & PCS & $18 \mathrm{Oct}$ & 0512 & 52.00 & 54.00 & 3.41 & 170.5 & Seawater & $45 \mathrm{bar}$ \\
\hline $28 \mathrm{H}$ & PCS & 18 Oct & 0607 & 54.00 & 56.00 & 3.36 & 168 & Seawater & $45 \mathrm{bar}$ \\
\hline $29 \mathrm{H}$ & PCS & 18 Oct & 0712 & 56.00 & 58.00 & 3.12 & 156 & Seawater & $45 \mathrm{bar}$ \\
\hline \multirow[t]{2}{*}{$30 \mathrm{H}$} & PCS & 18 Oct & 0816 & 58.00 & 60.00 & 3.40 & 170 & Seawater & 10 bar but may be heave pressure after firing \\
\hline & & 18 Oct & 0900 & & & & & & Standby for weather \\
\hline $31 \mathrm{H}$ & PCS & 18 Oct & 1645 & 60.00 & 62.00 & 3.35 & 167.5 & Seawater & $73 \mathrm{bar}$ \\
\hline $32 \mathrm{H}$ & PCS & 18 Oct & 1745 & 62.00 & 64.00 & 3.41 & 170.5 & Seawater & \\
\hline $33 \mathrm{H}$ & PCS & 18 Oct & 1845 & 64.00 & 66.00 & 3.48 & 174 & Seawater & \\
\hline $34 \mathrm{H}$ & PCS & 18 Oct & 1945 & 66.00 & 68.00 & 3.52 & 176 & Seawater & \\
\hline $35 \mathrm{H}$ & PCS & 18 Oct & 2040 & 68.00 & 70.00 & 3.60 & 180 & Seawater & $63 \mathrm{bar}$ \\
\hline $36 \mathrm{H}$ & PCS & 18 Oct & 2140 & 70.00 & 72.00 & 2.71 & 135.5 & Seawater & $20 \mathrm{bar}$ \\
\hline
\end{tabular}


Table T1 (continued).

\begin{tabular}{|c|c|c|c|c|c|c|c|c|c|}
\hline \multirow[b]{2}{*}{ Core } & \multirow{2}{*}{$\begin{array}{l}\text { Coring } \\
\text { method }\end{array}$} & \multirow{2}{*}{$\begin{array}{l}\text { Date } \\
\text { (2013) }\end{array}$} & \multirow{2}{*}{$\begin{array}{l}\text { Time } \\
\text { (UTC) }\end{array}$} & \multicolumn{2}{|c|}{ Depth (mbsf) } & \multirow{2}{*}{$\begin{array}{l}\text { Recovered } \\
\text { (m) }\end{array}$} & \multirow{2}{*}{$\begin{array}{l}\text { Recovery } \\
\text { (\%) }\end{array}$} & \multirow[b]{2}{*}{ Mud type } & \multirow[b]{2}{*}{ Comments } \\
\hline & & & & Top & Bottom & & & & \\
\hline $37 \mathrm{H}$ & PCS & 18 Oct & 2235 & 72.00 & 74.00 & 3.01 & 150.5 & Seawater & $60 \mathrm{bar}$ \\
\hline 380 & NCA & 18 Oct & 2314 & 74.00 & 75.30 & 0.00 & 0 & Seawater & Driller mistakenly drilled below the base of the previous piston run \\
\hline $39 \mathrm{H}$ & PCS & 18 Oct & 2320 & 75.30 & 78.60 & 3.14 & 95.15 & Seawater & $30 \mathrm{bar}$ \\
\hline $40 \mathrm{H}$ & PCS & 19 Oct & 0040 & 78.60 & 81.90 & 3.36 & 101.82 & Seawater & $80 \mathrm{bar}$ \\
\hline $41 \mathrm{H}$ & PCS & 19 Oct & 0140 & 81.90 & 85.20 & 3.49 & 105.76 & Seawater & $60 \mathrm{bar}$ \\
\hline $42 \mathrm{H}$ & PCS & 19 Oct & 0248 & 85.20 & 88.50 & 3.41 & 103.33 & Seawater & $60 \mathrm{bar}$ \\
\hline $43 \mathrm{H}$ & PCS & 19 Oct & 0345 & 88.50 & 91.80 & 3.30 & 100 & Seawater & $65 \mathrm{bar}$ \\
\hline \multirow[t]{3}{*}{$44 \mathrm{H}$} & PCS & 19 Oct & 0532 & 91.80 & 92.80 & 1.01 & 101 & Seawater & Erratic firing and lifted pipe, stones in till when recovered \\
\hline & & 19 Oct & 0610 & & & & & & Decision made to terminate borehole at this total depth \\
\hline & & 19 Oct & 0630 & & & & & & Commenced tripping pipe \\
\hline
\end{tabular}

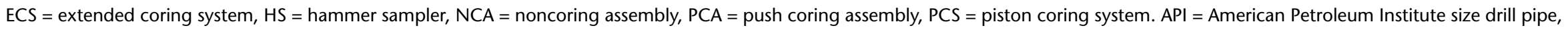
$\mathrm{BHA}=$ bottom-hole assembly, $\mathrm{PC}=$ piston core

Table T2. Diatoms, Hole M0063A. This table is available in an oversized format. 


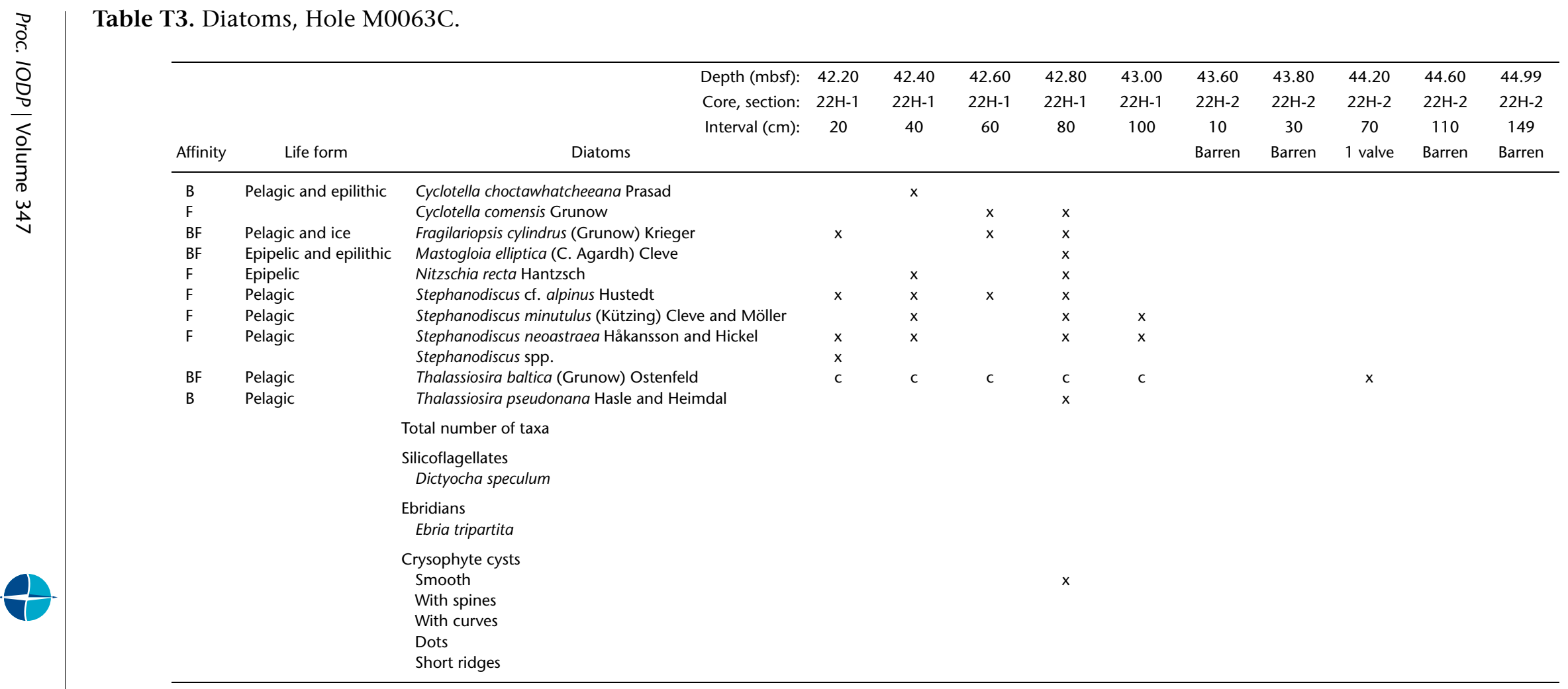

$\mathrm{F}=$ freshwater, $\mathrm{BF}=$ brackish-freshwater, $\mathrm{B}=$ brackish, $\mathrm{BM}=$ brackish-marine, $\mathrm{M}=$ marine.

Table T4. Diatoms, Hole M0063E. This table is available in an oversized format. 
Table T6. Foraminifers, Site M0063. (Continued on next page.)

\begin{tabular}{|c|c|c|c|c|c|c|c|c|}
\hline \multirow{2}{*}{$\begin{array}{l}\text { Hole, core, section, } \\
\text { interval }(\mathrm{cm})\end{array}$} & \multicolumn{2}{|c|}{ Depth (mbsf) } & \multirow[t]{2}{*}{ 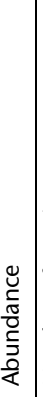 } & \multirow[t]{2}{*}{ 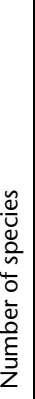 } & \multirow[t]{2}{*}{ 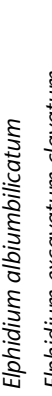 } & \multirow{2}{*}{\multicolumn{2}{|c|}{ 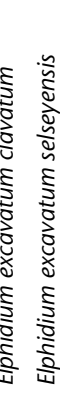 }} & \multirow[t]{2}{*}{ 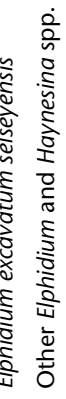 } \\
\hline & Top & Bottom & & & & & & \\
\hline \multicolumn{9}{|l|}{$347-$} \\
\hline M0063C-1H-1, 47-49 & 0.47 & 0.49 & V & 1 & & $x$ & & \\
\hline M0063C-1H-1, 74-76 & 0.74 & 0.76 & C & 3 & $x$ & $x$ & $x$ & \\
\hline M0063D-1H-1, 75-77 & 0.75 & 0.77 & C & 3 & $\mathrm{x}$ & $x$ & $\mathrm{x}$ & \\
\hline M0063C-1H-2, 15-17 & 1.65 & 1.67 & A & 1 & & $x$ & & \\
\hline M0063D-1H-2, 15-17 & 1.65 & 1.67 & $\mathrm{~F}$ & 2 & & $x$ & $x$ & \\
\hline M0063B-1H-CC & 1.49 & 1.79 & C & 2 & & $x$ & & $\mathrm{x}$ \\
\hline M0063E-1H-CC & 2.70 & 2.80 & C & 1 & & $x$ & & \\
\hline M0063D-2H-2, 15-17 & 3.15 & 3.17 & V & 1 & & $x$ & & \\
\hline M0063D-1H-CC & 3.09 & 3.31 & $\mathrm{~F}$ & 1 & & $x$ & & \\
\hline M0063C-2H-2, 15-17 & 3.64 & 3.66 & C & 3 & & $x$ & $x$ & $x$ \\
\hline M0063C-1H-CC & 3.59 & 3.71 & C & 1 & & $\mathrm{x}$ & & \\
\hline M0063A-2H-CC & 3.82 & 3.97 & $\mathrm{~F}$ & 2 & $x$ & $\mathrm{x}$ & & \\
\hline M0063D-3H-2, 15-17 & 4.76 & 4.78 & $\mathrm{~F}$ & 1 & & $x$ & & \\
\hline M0063C-2H-CC & 4.99 & 5.12 & B & & & & & \\
\hline M0063D-2H-CC & 5.06 & 5.23 & $\mathrm{~F}$ & 1 & & $x$ & & \\
\hline M0063C-3H-2, 17-19 & 5.22 & 5.24 & $\mathrm{~F}$ & 2 & $x$ & $x$ & & \\
\hline M0063E-2H-CC & 5.39 & 5.49 & A & 1 & & $x$ & & \\
\hline M0063B-2H-CC & 5.50 & 5.70 & C & 3 & $x$ & $x$ & $\mathrm{x}$ & \\
\hline M0063E-3H-CC & 6.15 & 6.25 & C & 1 & & $x$ & & \\
\hline M0063A-3H-CC & 6.29 & 6.39 & $\mathrm{R}$ & 1 & & $x$ & & \\
\hline M0063C-3H-CC & 6.41 & 6.50 & $\mathrm{~F}$ & 1 & & $x$ & & \\
\hline M0063B-3H-CC & 6.41 & 6.61 & C & 1 & & $x$ & & \\
\hline M0063D-3H-CC & 6.38 & 6.68 & C & 1 & & $x$ & & \\
\hline M0063D-4H-2, 15-17 & 7.13 & 7.15 & C & 1 & & $x$ & & \\
\hline M0063C-4H-2, 15-17 & 7.65 & 7.67 & C & 3 & & $x$ & $\mathrm{x}$ & $x$ \\
\hline M0063D-4H-CC & 7.71 & 7.76 & A & 1 & & $\mathrm{x}$ & & \\
\hline M0063C-4H-CC & 8.12 & 8.24 & A & 1 & & $x$ & & \\
\hline M0063E-4H-CC & 8.14 & 8.24 & A & 1 & & $x$ & & \\
\hline M0063B-4H-CC & 8.19 & 8.34 & $\mathrm{~F}$ & 2 & & $x$ & & $\mathrm{x}$ \\
\hline M0063D-5H-2, 15-17 & 9.15 & 9.17 & C & 1 & & $x$ & & \\
\hline M0063A-4H-CC & 9.20 & 9.30 & C & 2 & & $\mathrm{x}$ & & $\mathrm{x}$ \\
\hline M0063C-5H-2, 15-17 & 9.65 & 9.67 & C & 2 & & $\mathrm{x}$ & $x$ & \\
\hline M0063D-5H-CC & 9.62 & 9.71 & A & 1 & & $\mathrm{x}$ & & \\
\hline M0063E-5H-CC & 10.60 & 10.70 & A & 1 & & $\mathrm{x}$ & & \\
\hline M0063D-6H-2, 15-17 & 10.88 & 10.90 & $\mathrm{R}$ & 1 & & $x$ & & \\
\hline M0063C-5H-CC & 10.92 & 11.02 & A & 1 & & $x$ & & \\
\hline M0063B-5H-CC & 11.35 & 11.50 & C & 2 & & $x$ & & $\mathrm{x}$ \\
\hline M0063C-6H-2, 15-17 & 11.59 & 11.61 & $\mathrm{~F}$ & 1 & & $x$ & & \\
\hline M0063D-6H-CC & 11.79 & 11.82 & A & 1 & & $\mathrm{x}$ & & \\
\hline M0063C-6H-CC & 12.29 & 12.44 & A & 2 & & $x$ & & $\mathrm{x}$ \\
\hline M0063B-6H-CC & 12.51 & 12.61 & C & 1 & & $x$ & & \\
\hline M0063E-6H-CC & 12.61 & 12.71 & A & 1 & & $x$ & & \\
\hline M0063D-7H-2, 15-17 & 13.01 & 13.03 & A & 1 & & $x$ & & \\
\hline M0063A-5H-CC & 13.03 & 13.05 & $\mathrm{~F}$ & 1 & & $\mathrm{x}$ & & \\
\hline M0063C-7H-2, 15-17 & 13.64 & 13.66 & A & 1 & & $x$ & & \\
\hline M0063D-7H-CC & 14.05 & 14.09 & C & 1 & & $x$ & & \\
\hline M0063C-7H-CC & 14.48 & 14.68 & C & 2 & & $\mathrm{x}$ & & $x$ \\
\hline M0063E-7H-CC & 14.74 & 14.84 & A & 1 & & $x$ & & \\
\hline M0063B-7H-CC & 15.46 & 15.60 & $\mathrm{~F}$ & 2 & & $x$ & & $\mathrm{x}$ \\
\hline M0063C-8H-2, 15-17 & 15.59 & 15.61 & A & 1 & & $x$ & & \\
\hline M0063A-6H-CC & 16.30 & 16.40 & C & 1 & & $x$ & & \\
\hline M0063C-8H-CC & 16.29 & 16.51 & $\mathrm{~F}$ & 1 & & $\mathrm{x}$ & & \\
\hline M0063D-8H-CC & 16.50 & 16.64 & A & 1 & & $x$ & & \\
\hline M0063D-9H-2, 19-21 & 17.19 & 17.21 & A & 1 & & $x$ & & \\
\hline M0063C-9H-2, 15-17 & 17.65 & 17.67 & A & 1 & & $x$ & & \\
\hline M0063D-9H-CC & 17.80 & 17.85 & A & 1 & & $\mathrm{x}$ & & \\
\hline M0063B-8H-CC & 18.14 & 18.16 & C & 1 & & $x$ & & \\
\hline
\end{tabular}

\begin{tabular}{|c|c|c|c|c|c|c|c|}
\hline \multirow{2}{*}{$\begin{array}{l}\text { Hole, core, section, } \\
\text { interval }(\mathrm{cm})\end{array}$} & \multicolumn{2}{|c|}{ Depth (mbsf) } & \multirow{2}{*}{ 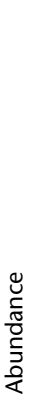 } & \multirow[t]{2}{*}{ 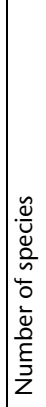 } & \multirow[t]{2}{*}{ 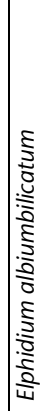 } & \multirow[t]{2}{*}{ 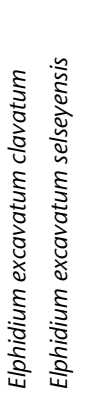 } & 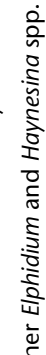 \\
\hline & Top & Bottom & & & & & \\
\hline M0063C-10H-1, 15-17 & 18.15 & 18.17 & $\mathrm{R}$ & 1 & & $\mathrm{x}$ & \\
\hline M0063C-9H-CC & 18.43 & 18.61 & A & 2 & & $x$ & $\mathrm{x}$ \\
\hline M0063D-10H-2, 16-18 & 19.01 & 19.03 & C & 1 & & $\mathrm{x}$ & \\
\hline M0063A-7H-CC & 19.16 & 19.21 & $\mathrm{R}$ & 2 & & $x$ & $\mathrm{x}$ \\
\hline M0063B-9H-CC & 19.48 & 19.50 & A & 2 & & $x$ & $\mathrm{x}$ \\
\hline M0063C-10H-CC & 20.53 & 20.60 & B & & & & \\
\hline M0063D-10H-CC & 20.61 & 20.67 & A & 1 & & $x$ & \\
\hline M0063B-10H-CC & 21.62 & 21.64 & $\mathrm{~V}$ & 1 & & $\mathrm{x}$ & \\
\hline M0063C-11H-2, 15-17 & 21.65 & 21.67 & B & & & & \\
\hline M0063C-11H-CC & 22.59 & 22.64 & $\mathrm{R}$ & 1 & & $x$ & \\
\hline M0063D-12H-2, 15-17 & 23.15 & 23.17 & $\mathrm{~V}$ & 1 & $x$ & & \\
\hline M0063A-8H-CC & 23.08 & 23.20 & C & 2 & & $\mathrm{x}$ & $\mathrm{x}$ \\
\hline M0063C-12H-2, 15-17 & 23.65 & 23.67 & B & & & & \\
\hline M0063D-13H-2, 14-16 & 24.20 & 24.22 & $\mathrm{~V}$ & 2 & $x$ & $\mathrm{x}$ & \\
\hline M0063B-11H-CC & 24.40 & 24.45 & $\mathrm{~V}$ & 1 & & $\mathrm{x}$ & \\
\hline M0063D-12H-CC & 24.56 & 24.58 & A & 2 & & $x$ & $\mathrm{x}$ \\
\hline M0063C-12H-CC & 24.60 & 24.68 & C & 2 & & $\mathrm{x}$ & $\mathrm{x}$ \\
\hline M0063C-13H-2, 15-17 & 25.57 & 25.59 & V & 1 & & $x$ & \\
\hline M0063D-13H-CC & 25.83 & 25.88 & $\mathrm{~F}$ & 1 & & $\mathrm{x}$ & \\
\hline M0063D-14H-2, 12-14 & 26.05 & 26.07 & $\mathrm{v}$ & \begin{tabular}{|llllll} 
& 1 & & & & \\
\end{tabular} & & $\mathrm{x}$ & \\
\hline M0063B-12H-CC & 26.22 & 26.27 & $\mathrm{R}$ & \begin{tabular}{|llllll} 
& 1 & & & & \\
\end{tabular} & & $\mathrm{x}$ & \\
\hline M0063A-9H-CC & 26.21 & 26.36 & C & \begin{tabular}{|llllll} 
& 1 & & & & \\
\end{tabular} & & $\mathrm{x}$ & \\
\hline M0063C-13H-CC & 27.18 & 27.23 & V & 1 & & $x$ & \\
\hline M0063D-14H-CC & 27.36 & 27.52 & $\mathrm{~V}$ & 1 & & $\mathrm{x}$ & \\
\hline M0063C-14H-2, 14-16 & 27.64 & 27.66 & B & & & & \\
\hline M0063B-13H-CC & 28.08 & 28.10 & $\mathrm{~V}$ & \begin{tabular}{|lllllll} 
& 1 & & & & \\
\end{tabular} & & $\mathrm{x}$ & \\
\hline M0063D-15H-2, 17-19 & 28.44 & 28.46 & $\mathrm{~V}$ & \begin{tabular}{|llllll} 
& 1 & & & & \\
\end{tabular} & & $\mathrm{x}$ & \\
\hline M0063C-14H-CC & 28.73 & 28.78 & $\mathrm{v}$ & \begin{tabular}{|lllllll} 
& 1 & & & & &
\end{tabular} & & $\mathrm{x}$ & \\
\hline M0063D-15H-CC & 29.34 & 29.47 & B & & & & \\
\hline M0063C-15H-2, 15-17 & 29.65 & 29.67 & B & & & & \\
\hline M0063A-10H-CC & 29.82 & 29.84 & $\mathrm{~V}$ & 1 & & $\mathrm{x}$ & \\
\hline M0063B-14H-CC & 29.79 & 29.85 & $\mathrm{R}$ & \begin{tabular}{|llllll} 
& 1 & & & & \\
\end{tabular} & & $\mathrm{x}$ & \\
\hline M0063D-16H-2, 15-17 & 30.65 & 30.67 & B & & & & \\
\hline M0063C-15H-CC & 30.74 & 30.94 & B & & & & \\
\hline M0063D-16H-CC & 31.56 & 31.58 & B & & & & \\
\hline M0063C-16H-2, 15-17 & 31.65 & 31.67 & B & & & & \\
\hline M0063D-17H-2, 15-17 & 32.65 & 32.67 & B & & & & \\
\hline M0063A-11H-CC & 32.74 & 32.82 & B & & & & \\
\hline M0063C-16H-CC & 32.81 & 33.00 & B & & & & \\
\hline M0063C-17H-2, 15-17 & 33.65 & 33.67 & B & & & & \\
\hline M0063D-17H-CC & 33.99 & 34.01 & B & & & & \\
\hline M0063D-18H-2, 17-19 & 34.67 & 34.69 & B & & & & \\
\hline M0063C-18H-2, 15-17 & 35.65 & 35.67 & B & & & & \\
\hline M0063C-17H-CC & 35.63 & 35.68 & B & & & & \\
\hline M0063D-18H-CC & 35.90 & 35.92 & B & & & & \\
\hline M0063A-12H-CC & 36.29 & 36.39 & B & & & & \\
\hline M0063D-19H-2, 15-17 & 36.65 & 36.67 & B & & & & \\
\hline M0063E-18H-CC & 37.10 & 37.35 & B & & & & \\
\hline M0063C-18H-CC & 37.59 & 37.64 & B & & & & \\
\hline M0063C-19H-2, 15-17 & 37.65 & 37.67 & B & & & & \\
\hline M0063D-19H-CC & 37.70 & 37.72 & B & & & & \\
\hline M0063D-20H-2, 15-17 & 38.65 & 38.67 & B & & & & \\
\hline M0063E-19H-CC & 38.64 & 38.82 & B & & & & \\
\hline M0063C-19H-CC & 38.75 & 38.90 & B & & & & \\
\hline M0063D-20H-CC & 39.62 & 39.64 & B & & & & \\
\hline M0063C-20H-2, 15-17 & 39.65 & 39.67 & B & & & & \\
\hline M0063A-13H-CC & 39.85 & 39.87 & B & & & & \\
\hline M0063C-20H-CC & 41.31 & 41.36 & B & & & & \\
\hline
\end{tabular}


Table T6 (continued).

\begin{tabular}{|c|c|c|c|c|c|c|}
\hline \multirow{2}{*}{$\begin{array}{l}\text { Hole, core, section, } \\
\text { interval }(\mathrm{cm})\end{array}$} & \multicolumn{2}{|c|}{ Depth (mbsf) } & \multirow{2}{*}{ 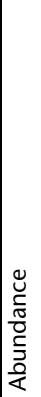 } & \multirow[t]{2}{*}{ 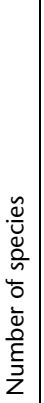 } & \multirow[t]{2}{*}{ 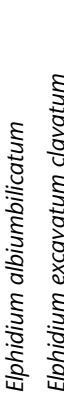 } & \multirow[t]{2}{*}{ 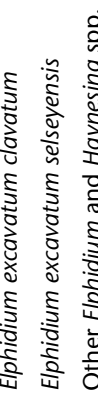 } \\
\hline & Top & Bottom & & & & \\
\hline M0063C-21H-2, 15-17 & 41.65 & 41.67 & B & & & \\
\hline M0063D-21H-CC & 41.89 & 41.91 & B & & & \\
\hline M0063A-14H-CC & 43.20 & 43.22 & B & & & \\
\hline M0063C-21H-CC & 43.29 & 43.34 & B & & & \\
\hline M0063C-22H-2, 15-17 & 43.65 & 43.67 & B & & & \\
\hline M0063D-22H-CC & 43.96 & 43.98 & B & & & \\
\hline M0063C-22H-CC & 45.45 & 45.48 & $B$ & & & \\
\hline M0063C-23H-2, 15-17 & 45.65 & 45.67 & V & 1 & & $x$ \\
\hline M0063D-23H-CC & 45.67 & 45.69 & $B$ & & & \\
\hline M0063D-24H-2, 15-17 & 46.15 & 46.17 & B & & & \\
\hline M0063A-15H-CC & 46.38 & 46.40 & B & & & \\
\hline M0063C-23H-CC & 47.03 & 47.05 & B & & & \\
\hline M0063D-24H-CC & 47.56 & 47.58 & B & & & \\
\hline M0063C-24H-2, 15-17 & 47.65 & 47.67 & B & & & \\
\hline M0063D-25H-2, 15-17 & 48.15 & 48.17 & B & & & \\
\hline M0063C-24H-CC & 48.89 & 48.91 & B & & & \\
\hline M0063A-16H-CC & 49.61 & 49.64 & B & & & \\
\hline M0063C-25H-2, 15-17 & 49.65 & 49.67 & B & & & \\
\hline M0063D-25H-CC & 49.67 & 49.69 & B & & & \\
\hline M0063D-26H-2, 15-17 & 50.15 & 50.17 & B & & & \\
\hline M0063C-25H-CC & 51.06 & 51.08 & $B$ & & & \\
\hline M0063D-26H-CC & 51.62 & 51.65 & B & & & \\
\hline M0063C-26H-2, 15-17 & 51.65 & 51.67 & B & & & \\
\hline M0063A-17H-CC & 52.80 & 52.84 & B & & & \\
\hline M0063C-26H-CC & 52.83 & 52.86 & B & & & \\
\hline M0063D-27H-CC & 53.37 & 53.39 & B & & & \\
\hline M0063C-27H-2, 15-17 & 53.65 & 53.67 & B & & & \\
\hline M0063D-28H-2, 15-17 & 54.15 & 54.17 & B & & & \\
\hline M0063D-28H-CC & 54.60 & 54.66 & B & & & \\
\hline M0063C-27H-CC & 54.76 & 54.81 & B & & & \\
\hline M0063D-30H-2, 15-17 & 55.85 & 55.87 & $B$ & & & \\
\hline M0063A-18H-CC & 56.02 & 56.04 & B & & & \\
\hline M0063C-28H-CC & 57.11 & 57.14 & $B$ & & & \\
\hline M0063D-30H-CC & 57.20 & 57.22 & B & & & \\
\hline M0063A-19H-CC & 57.25 & 57.32 & B & & & \\
\hline M0063D-31H-2, 15-17 & 57.85 & 57.87 & B & & & \\
\hline M0063D-31H-CC & 59.39 & 59.41 & B & & & \\
\hline M0063D-32H-2, 15-17 & 60.35 & 60.35 & B & & & \\
\hline M0063D-32H-CC & 62.15 & 62.17 & B & & & \\
\hline M0063A-20H-CC & 62.77 & 62.79 & B & & & \\
\hline M0063D-33H-2, 15-17 & 62.85 & 62.85 & B & & & \\
\hline
\end{tabular}

\begin{tabular}{|c|c|c|c|c|c|}
\hline \multirow{2}{*}{$\begin{array}{l}\text { Hole, core, section, } \\
\text { interval }(\mathrm{cm})\end{array}$} & \multicolumn{2}{|c|}{ Depth (mbsf) } & \multirow{2}{*}{\multicolumn{2}{|c|}{ 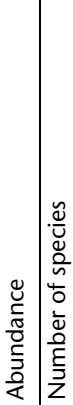 }} & \multirow[t]{2}{*}{ 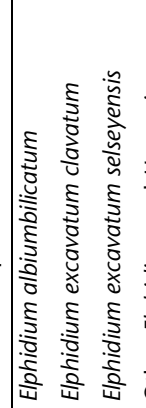 } \\
\hline & Top & Bottom & & & \\
\hline M0063D-33H-CC & 64.21 & 64.23 & B & & \\
\hline M0063C-30H-CC & 64.47 & 64.54 & B & & \\
\hline M0063D-34H-2, 15-17 & 65.35 & 65.37 & B & & \\
\hline M0063A-21H-CC & 65.76 & 65.78 & B & & \\
\hline M0063D-34H-CC & 66.32 & 66.34 & B & & \\
\hline M0063D-35H-CC & 66.81 & 66.83 & B & & \\
\hline M0063D-35H-1, 59-61 & 67.59 & 67.59 & B & & \\
\hline M0063C-31H-CC & 67.93 & 67.95 & B & & \\
\hline M0063D-36H-2, 15-17 & 69.25 & 69.27 & B & & \\
\hline M0063A-22H-CC & 69.37 & 69.40 & $\mathrm{~V}$ & 1 & \\
\hline M0063D-36H-CC & 69.78 & 69.79 & B & & \\
\hline $\mathrm{M} 0063 \mathrm{C}-32 \mathrm{H}-\mathrm{CC}$ & 71.22 & 71.24 & B & & \\
\hline M0063D-37H-2, 15-17 & 71.95 & 71.97 & B & & \\
\hline M0063A-23H-CC & 72.47 & 72.49 & B & & \\
\hline M0063C-33H-2, 15-17 & 72.65 & 72.67 & B & & \\
\hline M0063D-37H-CC & 73.47 & 73.73 & B & & \\
\hline M0063C-33H-CC & 74.49 & 74.54 & B & & \\
\hline M0063D-38H-2, 15-17 & 75.25 & 75.27 & B & & \\
\hline M0063A-24H-CC & 75.80 & 75.82 & B & & \\
\hline M0063C-34H-CC & 77.92 & 77.97 & B & & \\
\hline M0063D-39H-2, 15-17 & 78.55 & 78.57 & B & & \\
\hline M0063A-25H-CC & 79.22 & 79.24 & B & & \\
\hline M0063C-35H-CC & 80.89 & 81.07 & B & & \\
\hline M0063D-40H-2, 15-17 & 81.85 & 81.87 & B & & \\
\hline M0063A-26H-CC & 82.32 & 82.34 & B & & \\
\hline M0063C-36H-CC & 84.21 & 84.35 & B & & \\
\hline M0063A-27H-CC & 85.66 & 85.68 & B & & \\
\hline M0063D-41H-CC & 87.04 & 87.06 & B & & \\
\hline M0063C-37H-CC & 87.66 & 87.71 & B & & \\
\hline M0063A-28H-CC & 89.03 & 89.05 & B & & \\
\hline M0063C-38H-CC & 90.85 & 90.96 & B & & \\
\hline M0063A-29H-CC & 92.19 & 92.25 & B & & \\
\hline M0063E-44H-CC & 92.69 & 92.91 & B & & \\
\hline M0063C-39H-CC & 93.25 & 93.30 & B & & \\
\hline M0063A-30H-CC & 93.88 & 93.90 & B & & \\
\hline M0063A-31H-CC & 96.82 & 96.85 & B & & \\
\hline M0063A-36P-CC & 102.40 & 102.46 & B & & \\
\hline
\end{tabular}

Abundance: $A=$ abundant, $C=$ common, $F=$ few, $R=$ rare, $B=$ barren, $V=$ very high. 
Table T7. Distribution and abundance of ostracods, Site M0063. (Continued on next page.)

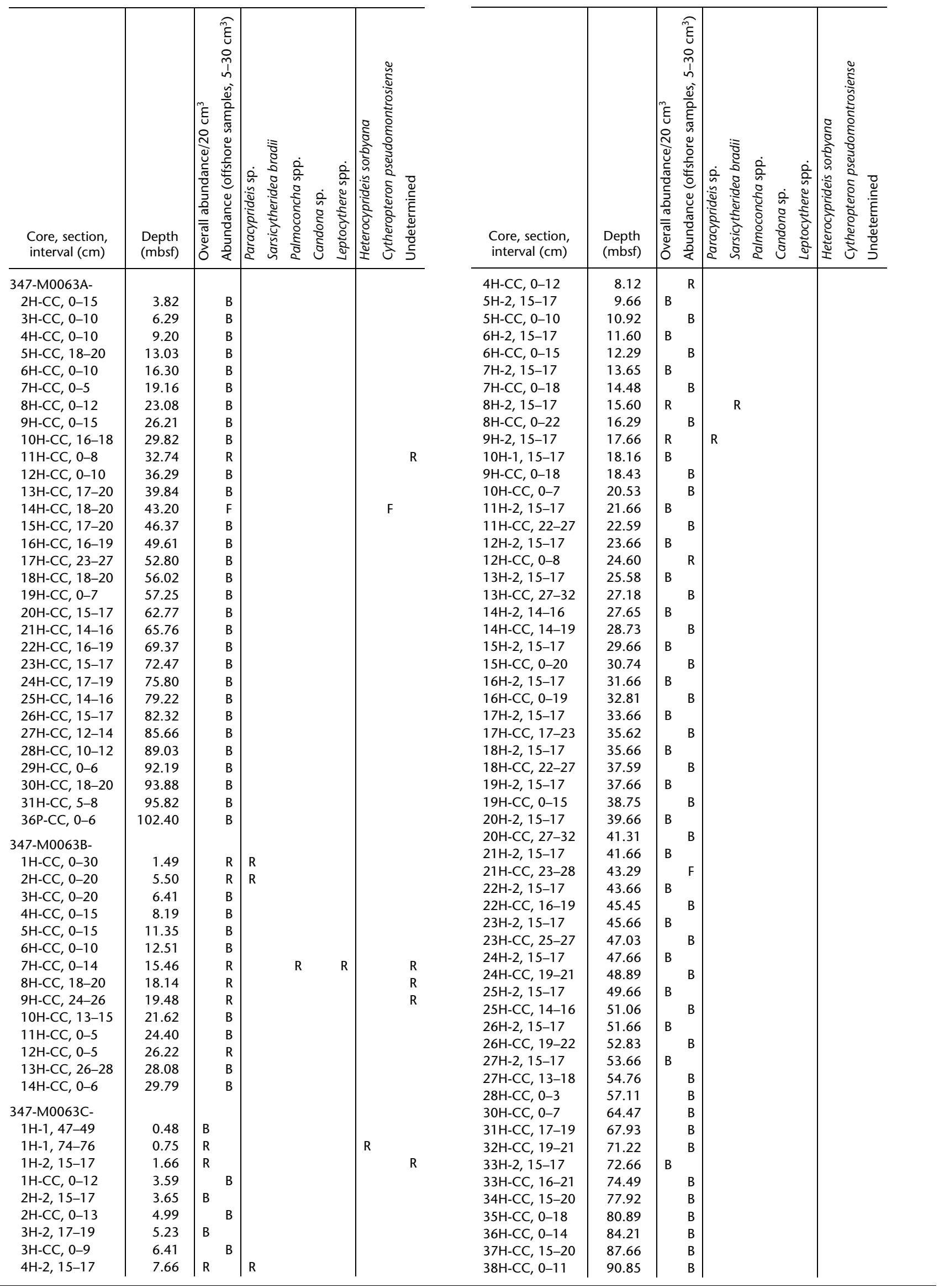


Table T7 (continued).

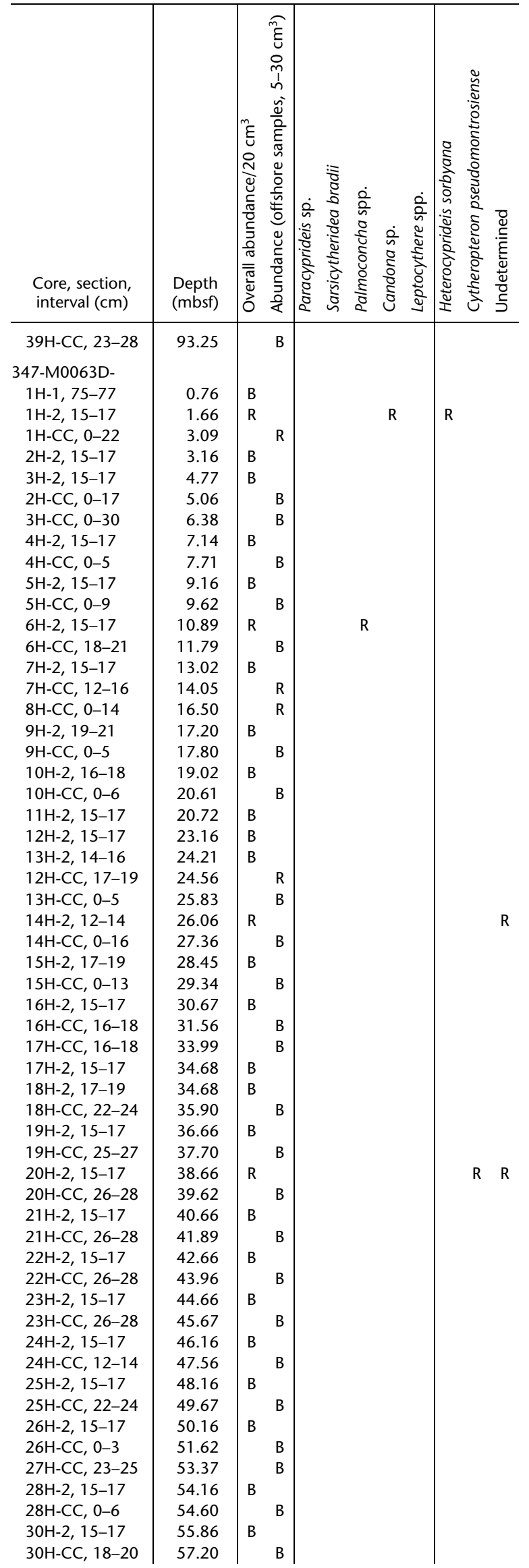

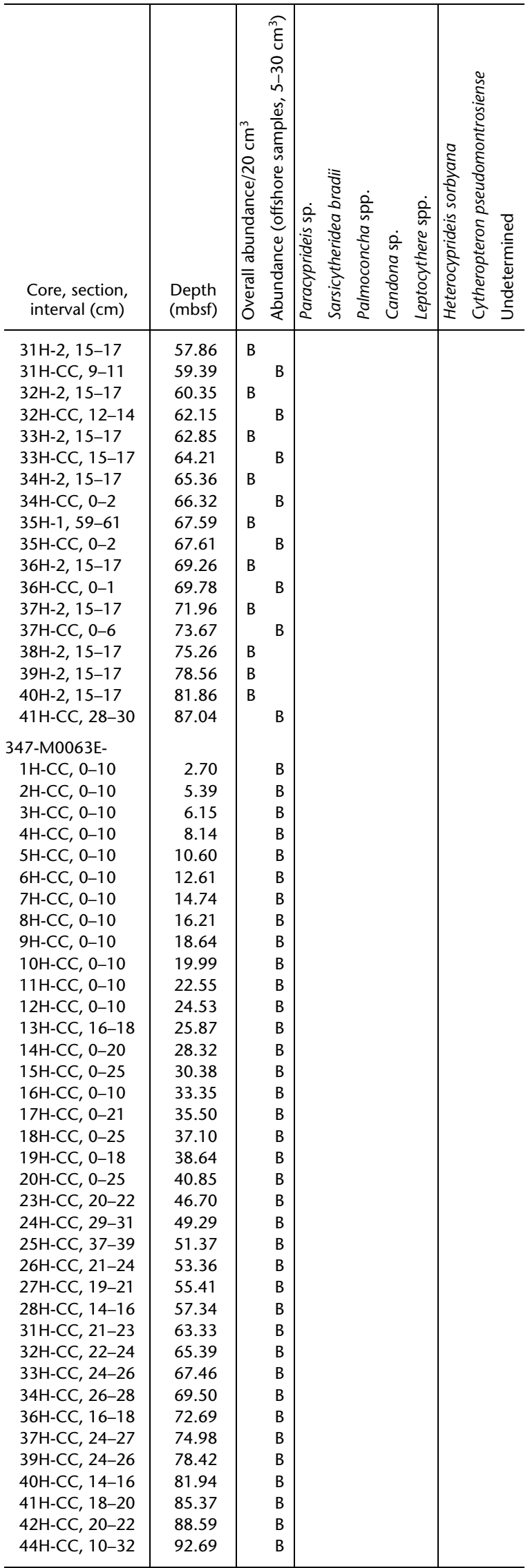

Abundance: $F=$ few, $R=$ rare, $B=$ barren. 
Table T8. Interstitial water geochemistry, Site M0063. This table is available in an oversized format.

Table T9. Calculated salinities and elemental ratios of interstitial water, Site M0063. (Continued on next four pages.)

\begin{tabular}{|c|c|c|c|c|c|c|c|c|c|}
\hline $\begin{array}{l}\text { Core, section, } \\
\text { interval }(\mathrm{cm})\end{array}$ & Type & $\begin{array}{l}\text { Depth } \\
\text { (mbsf) }\end{array}$ & $\begin{array}{l}\text { Cl-based } \\
\text { salinity }\end{array}$ & $\begin{array}{c}\mathrm{Na} / \mathrm{Cl} \\
(\mathrm{mM} / \mathrm{mM})\end{array}$ & $\begin{array}{c}\mathrm{Ca} / \mathrm{Cl} \\
(\mathrm{mM} / \mathrm{mM})\end{array}$ & $\begin{array}{c}\mathrm{Mg} / \mathrm{Cl} \\
(\mathrm{mM} / \mathrm{mM})\end{array}$ & $\begin{array}{c}\mathrm{K} / \mathrm{Cl} \\
(\mathrm{mM} / \mathrm{mM})\end{array}$ & $\begin{array}{c}\mathrm{Br} / \mathrm{Cl} \\
(\mu \mathrm{M} / \mathrm{mM})\end{array}$ & $\begin{array}{c}\mathrm{B} / \mathrm{Cl} \\
(\mu \mathrm{M} / \mathrm{mM})\end{array}$ \\
\hline \multicolumn{10}{|l|}{ 347-M0063A- } \\
\hline $2 \mathrm{H}-2,135-140$ & $\mathrm{Rh}$ & 1.52 & 10.81 & 1.08 & 0.03 & 0.14 & 0.03 & 1.78 & 1.44 \\
\hline $2 \mathrm{H}-3,135-140$ & $\mathrm{Rh}$ & 3.02 & 10.47 & 0.85 & 0.02 & 0.11 & 0.03 & 1.83 & 1.16 \\
\hline $3 \mathrm{H}-2,128-133$ & $\mathrm{Rh}$ & 4.91 & - & - & - & - & - & - & - \\
\hline $3 \mathrm{H}-3,113-118$ & $\mathrm{Rh}$ & 6.19 & - & - & - & - & - & - & - \\
\hline $4 \mathrm{H}-1,135-140$ & $\mathrm{Rh}$ & 7.98 & 11.97 & 0.88 & 0.02 & 0.12 & 0.03 & 1.98 & 1.48 \\
\hline $4 \mathrm{H}-2,95-100$ & $\mathrm{Rh}$ & 9.08 & 12.06 & 0.92 & 0.02 & 0.13 & 0.03 & 1.99 & 1.70 \\
\hline $5 \mathrm{H}-2,135-140$ & $\mathrm{Rh}$ & 11.73 & 12.11 & 1.04 & 0.03 & 0.14 & 0.04 & 2.06 & 2.01 \\
\hline $5 \mathrm{H}-3,85-90$ & $\mathrm{Rh}$ & 12.73 & 12.05 & 0.88 & 0.02 & 0.12 & 0.03 & 2.06 & 1.57 \\
\hline $6 \mathrm{H}-1,95-100$ & $\mathrm{Rh}$ & 14.18 & 11.79 & 1.03 & 0.03 & 0.14 & 0.04 & 2.12 & 2.05 \\
\hline $6 \mathrm{H}-2,135-140$ & $\mathrm{Rh}$ & 15.68 & 11.26 & 0.92 & 0.02 & 0.12 & 0.03 & 2.14 & 1.76 \\
\hline $7 \mathrm{H}-1,135-140$ & $\mathrm{Rh}$ & 17.88 & 10.69 & 0.91 & 0.02 & 0.13 & 0.03 & 2.21 & 1.68 \\
\hline 7H-2, 101-106 & $\mathrm{Rh}$ & 19.04 & 10.45 & 0.90 & 0.02 & 0.13 & 0.03 & 2.23 & 1.59 \\
\hline $8 \mathrm{H}-1,135-140$ & $\mathrm{Rh}$ & 20.88 & 9.27 & - & - & - & - & 2.23 & - \\
\hline $9 \mathrm{H}-1,135-140$ & $\mathrm{Rh}$ & 24.18 & 9.38 & 0.94 & 0.04 & 0.13 & 0.03 & 2.24 & 1.38 \\
\hline $10 \mathrm{H}-1,127-132$ & $\mathrm{Rh}$ & 27.40 & 7.92 & 1.05 & 0.08 & 0.13 & 0.03 & 2.17 & 0.90 \\
\hline $11 \mathrm{H}-1,134-139$ & $\mathrm{Rh}$ & 30.77 & 6.25 & 0.82 & 0.11 & 0.10 & 0.01 & 2.10 & 0.41 \\
\hline $12 \mathrm{H}-1,135-140$ & $\mathrm{Rh}$ & 34.08 & 5.22 & 0.78 & 0.16 & 0.11 & 0.01 & 2.06 & 0.27 \\
\hline $13 \mathrm{H}-1,135-140$ & $\mathrm{Rh}$ & 37.38 & 3.85 & 0.70 & 0.19 & 0.13 & 0.01 & 2.17 & 0.32 \\
\hline $14 \mathrm{H}-1,135-140$ & $\mathrm{Rh}$ & 40.68 & 3.18 & 0.61 & 0.21 & 0.14 & 0.01 & 2.22 & 0.38 \\
\hline $15 \mathrm{H}-1,135-140$ & $\mathrm{Rh}$ & 43.98 & 2.18 & 0.56 & 0.29 & 0.17 & 0.01 & 2.34 & 0.45 \\
\hline $16 \mathrm{H}-1,135-140$ & $\mathrm{Rh}$ & 47.28 & 1.39 & 0.57 & 0.36 & 0.20 & 0.01 & 2.52 & 0.38 \\
\hline $17 \mathrm{H}-1,135-140$ & $\mathrm{Rh}$ & 50.58 & 0.98 & 0.67 & 0.45 & 0.22 & 0.01 & 2.76 & 0.30 \\
\hline $18 \mathrm{H}-1,135-140$ & $\mathrm{Rh}$ & 53.88 & 0.57 & 0.91 & 0.57 & 0.25 & 0.01 & 3.35 & 0.37 \\
\hline $19 \mathrm{H}-1,130-135$ & $\mathrm{Rh}$ & 57.13 & 3.89 & 0.67 & 0.16 & 0.09 & 0.01 & 1.67 & 0.32 \\
\hline $20 \mathrm{H}-1,135-140$ & $\mathrm{Rh}$ & 60.48 & 0.25 & 1.50 & 0.63 & 0.27 & 0.01 & 4.72 & 1.06 \\
\hline $21 \mathrm{H}-1,135-140$ & $\mathrm{Rh}$ & 63.78 & 0.25 & 1.55 & 0.51 & 0.20 & 0.01 & 4.42 & 1.44 \\
\hline $22 \mathrm{H}-1,134-139$ & $\mathrm{Rh}$ & 67.07 & 0.20 & 1.73 & 0.55 & 0.18 & 0.01 & 4.91 & 1.64 \\
\hline $23 \mathrm{H}-1,134-139$ & $\mathrm{Rh}$ & 70.37 & 0.06 & 4.50 & 1.22 & 0.31 & 0.04 & 12.75 & 4.59 \\
\hline $24 \mathrm{H}-1,135-140$ & $\mathrm{Rh}$ & 73.68 & 0.04 & 5.71 & 1.42 & 0.25 & 0.06 & 17.83 & 8.24 \\
\hline $25 \mathrm{H}-1,135-140$ & $\mathrm{Rh}$ & 76.98 & 0.08 & 2.79 & 0.69 & 0.09 & 0.03 & 9.00 & 4.83 \\
\hline $26 \mathrm{H}-1,135-140$ & $\mathrm{Rh}$ & 80.28 & 0.02 & 7.63 & 1.59 & 0.02 & 0.12 & 28.05 & 15.27 \\
\hline $27 \mathrm{H}-1,135-140$ & $\mathrm{Rh}$ & 83.58 & 0.00 & - & - & - & - & - & - \\
\hline $28 \mathrm{H}-1,135-140$ & $\mathrm{Rh}$ & 86.88 & 0.03 & 6.05 & 1.22 & 0.00 & 0.06 & 21.89 & 13.77 \\
\hline $29 \mathrm{H}-1,135-140$ & $\mathrm{Rh}$ & 90.18 & 0.04 & 3.83 & 0.80 & 0.00 & 0.05 & 12.86 & 8.44 \\
\hline $30 \mathrm{H}-1,125-130$ & $\mathrm{Rh}$ & 93.38 & 0.94 & 0.82 & 0.19 & 0.03 & 0.01 & 1.99 & 0.75 \\
\hline $31 \mathrm{H}-1,125-130$ & $\mathrm{Rh}$ & 95.18 & - & - & - & - & - & - & - \\
\hline $36 \mathrm{H}-1,45-50$ & $\mathrm{Rh}$ & 102.28 & 0.16 & 1.71 & 0.50 & 0.00 & 0.02 & 4.54 & 3.85 \\
\hline \multicolumn{10}{|l|}{ 347-M0063B- } \\
\hline $1 \mathrm{H}-1,134-139$ & $\mathrm{Rh}$ & 1.37 & 10.45 & 0.91 & 0.02 & 0.12 & 0.03 & 1.69 & 1.19 \\
\hline $2 \mathrm{H}-1,135-140$ & $\mathrm{Rh}$ & 3.38 & 10.60 & 0.81 & 0.02 & 0.10 & 0.03 & 1.78 & 1.08 \\
\hline $2 \mathrm{H}-2,135-140$ & $\mathrm{Rh}$ & 4.88 & 10.74 & 0.89 & 0.02 & 0.12 & 0.03 & 1.83 & 1.27 \\
\hline $3 \mathrm{H}-1,135-140$ & $\mathrm{Rh}$ & 5.38 & 11.12 & 0.84 & 0.02 & 0.12 & 0.03 & 1.94 & 1.37 \\
\hline $3 \mathrm{H}-2,76-81$ & $\mathrm{Rh}$ & 6.29 & 11.07 & 0.84 & 0.02 & 0.12 & 0.03 & 1.92 & 1.39 \\
\hline $4 \mathrm{H}-1,70-75$ & $\mathrm{Rh}$ & 6.73 & 11.65 & 0.89 & 0.02 & 0.13 & 0.03 & 1.92 & 1.62 \\
\hline $4 \mathrm{H}-2,119-124$ & $\mathrm{Rh}$ & 8.07 & 11.88 & 0.88 & 0.02 & 0.13 & 0.03 & 1.96 & 1.66 \\
\hline $5 \mathrm{H}-1,135-140$ & $\mathrm{Rh}$ & 9.38 & 10.10 & 0.86 & 0.02 & 0.12 & 0.03 & 1.85 & 1.58 \\
\hline $5 \mathrm{H}-2,135-140$ & $\mathrm{Rh}$ & 10.88 & 11.88 & 0.86 & 0.02 & 0.12 & 0.03 & 1.96 & 1.65 \\
\hline $6 \mathrm{H}-1,135-140$ & $\mathrm{Rh}$ & 11.38 & 12.23 & 0.99 & 0.03 & 0.14 & 0.03 & 2.02 & 1.80 \\
\hline $6 \mathrm{H}-2,86-91$ & $\mathrm{Rh}$ & 12.39 & 11.86 & 0.99 & 0.03 & 0.14 & 0.03 & 2.02 & 1.78 \\
\hline 7H-1, 135-140 & $\mathrm{Rh}$ & 13.38 & 11.39 & 0.92 & 0.03 & 0.13 & 0.03 & 2.06 & 1.50 \\
\hline 7H-2, 135-140 & $\mathrm{Rh}$ & 14.88 & 11.80 & 0.87 & 0.02 & 0.12 & 0.03 & 2.12 & 1.53 \\
\hline $8 \mathrm{H}-1,128-133$ & $\mathrm{Rh}$ & 16.31 & - & - & - & - & - & - & - \\
\hline $8 \mathrm{H}-2,115-120$ & $\mathrm{Rh}$ & 17.61 & 11.29 & 0.88 & 0.02 & 0.12 & 0.03 & 2.17 & 1.60 \\
\hline $9 \mathrm{H}-1,135-140$ & $\mathrm{Rh}$ & 18.38 & 11.02 & 0.88 & 0.02 & 0.13 & 0.03 & 2.18 & 1.51 \\
\hline $9 \mathrm{H}-2,59-64$ & $\mathrm{Rh}$ & 19.12 & 10.18 & 0.88 & 0.02 & 0.12 & 0.03 & 2.16 & 1.48 \\
\hline $10 \mathrm{H}-1,104-109$ & $\mathrm{Rh}$ & 20.07 & 10.41 & 0.87 & 0.02 & 0.13 & 0.03 & 2.21 & 1.45 \\
\hline $11 \mathrm{H}-1,135-140$ & $\mathrm{Rh}$ & 22.38 & - & - & - & - & - & - & - \\
\hline $12 \mathrm{H}-1,135-140$ & $\mathrm{Rh}$ & 24.38 & 9.33 & 0.83 & 0.04 & 0.12 & 0.03 & 2.22 & 1.07 \\
\hline $13 \mathrm{H}-1,132-137$ & $\mathrm{Rh}$ & 26.35 & 8.40 & 0.81 & 0.05 & 0.11 & 0.02 & 2.20 & 0.83 \\
\hline $14 \mathrm{H}-1,135-140$ & $\mathrm{Rh}$ & 28.38 & 7.78 & 0.78 & 0.06 & 0.10 & 0.02 & 2.15 & 0.69 \\
\hline
\end{tabular}


Table T9 (continued). (Continued on next page.)

\begin{tabular}{|c|c|c|c|c|c|c|c|c|c|}
\hline $\begin{array}{l}\text { Core, section, } \\
\text { interval }(\mathrm{cm})\end{array}$ & Type & $\begin{array}{l}\text { Depth } \\
\text { (mbsf) }\end{array}$ & $\begin{array}{l}\text { Cl-based } \\
\text { salinity }\end{array}$ & $\begin{array}{c}\mathrm{Na} / \mathrm{Cl} \\
(\mathrm{mM} / \mathrm{mM})\end{array}$ & $\begin{array}{c}\mathrm{Ca} / \mathrm{Cl} \\
(\mathrm{mM} / \mathrm{mM})\end{array}$ & $\begin{array}{c}\mathrm{Mg} / \mathrm{Cl} \\
(\mathrm{mM} / \mathrm{mM})\end{array}$ & $\begin{array}{c}\mathrm{K} / \mathrm{Cl} \\
(\mathrm{mM} / \mathrm{mM})\end{array}$ & $\begin{array}{c}\mathrm{Br} / \mathrm{Cl} \\
(\mu \mathrm{M} / \mathrm{mM})\end{array}$ & $\begin{array}{c}\mathrm{B} / \mathrm{Cl} \\
(\mu \mathrm{M} / \mathrm{mM})\end{array}$ \\
\hline \multicolumn{10}{|l|}{ 347-M0063C- } \\
\hline $1 \mathrm{H}-1,135-140$ & $\mathrm{Rh}$ & 1.38 & 10.42 & 0.81 & 0.02 & 0.10 & 0.02 & 1.71 & 1.06 \\
\hline $1 \mathrm{H}-2,135-140$ & $\mathrm{Rh}$ & 2.88 & 10.68 & 0.93 & 0.03 & 0.12 & 0.03 & 1.81 & 1.31 \\
\hline $2 \mathrm{H}-1,134-139$ & $\mathrm{Rh}$ & 3.37 & 10.93 & 0.82 & 0.02 & 0.11 & 0.03 & 1.87 & 1.23 \\
\hline $2 \mathrm{H}-2,135-140$ & $\mathrm{Rh}$ & 4.87 & 10.91 & 0.94 & 0.02 & 0.14 & 0.03 & 1.90 & 1.62 \\
\hline $3 \mathrm{H}-1,90-95$ & $\mathrm{Rh}$ & 4.93 & 11.28 & 0.84 & 0.02 & 0.12 & 0.03 & 1.93 & 1.56 \\
\hline $3 \mathrm{H}-2,121-126$ & $\mathrm{Rh}$ & 6.29 & 11.65 & 0.83 & 0.02 & 0.12 & 0.03 & 1.95 & 1.55 \\
\hline $4 \mathrm{H}-1,135-140$ & $\mathrm{Rh}$ & 7.38 & 11.84 & 0.84 & 0.02 & 0.12 & 0.03 & 1.97 & 1.56 \\
\hline $4 \mathrm{H}-2,47-52$ & $\mathrm{Rh}$ & 8.00 & 11.33 & 0.89 & 0.02 & 0.13 & 0.03 & 1.98 & 1.64 \\
\hline $5 \mathrm{H}-1,135-140$ & $\mathrm{Rh}$ & 9.38 & 10.93 & 0.86 & 0.02 & 0.12 & 0.03 & 1.89 & 1.64 \\
\hline $5 \mathrm{H}-2,127-132$ & $\mathrm{Rh}$ & 10.80 & 12.01 & 0.84 & 0.02 & 0.12 & 0.03 & 2.01 & 1.63 \\
\hline $6 \mathrm{H}-1,129-134$ & $\mathrm{Rh}$ & 11.32 & 12.03 & 0.89 & 0.03 & 0.13 & 0.03 & 2.07 & 1.69 \\
\hline $6 \mathrm{H}-2,70-75$ & $\mathrm{Rh}$ & 12.17 & 11.82 & 0.89 & 0.03 & 0.13 & 0.03 & 2.09 & 1.58 \\
\hline 7H-1, 134-139 & $\mathrm{Rh}$ & 13.37 & 11.76 & 1.04 & 0.03 & 0.15 & 0.04 & 2.11 & 2.04 \\
\hline $7 \mathrm{H}-2,84-89$ & $\mathrm{Rh}$ & 14.36 & 11.82 & 0.87 & 0.02 & 0.12 & 0.03 & 2.15 & 1.64 \\
\hline $8 \mathrm{H}-1,129-134$ & $\mathrm{Rh}$ & 15.32 & 11.56 & 0.85 & 0.02 & 0.12 & 0.03 & 2.18 & 1.59 \\
\hline $8 \mathrm{H}-2,70-75$ & $\mathrm{Rh}$ & 16.17 & 11.30 & 0.89 & 0.02 & 0.13 & 0.03 & 2.18 & 1.59 \\
\hline $9 \mathrm{H}-1,135-140$ & $\mathrm{Rh}$ & 17.38 & 10.76 & 0.88 & 0.01 & 0.12 & 0.03 & 0.95 & 1.60 \\
\hline $9 \mathrm{H}-2,78-83$ & $\mathrm{Rh}$ & 18.31 & 10.68 & 0.87 & 0.01 & 0.12 & 0.03 & 0.92 & 1.64 \\
\hline $10 \mathrm{H}-1,134-139$ & $\mathrm{Rh}$ & 19.37 & 10.70 & 0.85 & 0.02 & 0.13 & 0.03 & 2.06 & 1.52 \\
\hline $10 \mathrm{H}-2,89-94$ & $\mathrm{Rh}$ & 20.41 & - & - & - & - & - & - & - \\
\hline $11 \mathrm{H}-1,135-140$ & $\mathrm{Rh}$ & 21.38 & 9.65 & 0.83 & 0.02 & 0.13 & 0.03 & 2.20 & 1.28 \\
\hline $11 \mathrm{H}-2,72-77$ & $\mathrm{Rh}$ & 22.25 & 9.34 & 0.81 & 0.02 & 0.12 & 0.03 & 2.21 & 1.32 \\
\hline $12 \mathrm{H}-1,135-140$ & $\mathrm{Rh}$ & 23.38 & 9.58 & 0.84 & 0.03 & 0.12 & 0.03 & 2.22 & 1.31 \\
\hline $13 \mathrm{H}-1,127-132$ & $\mathrm{Rh}$ & 25.30 & 8.31 & 0.87 & 0.02 & 0.12 & 0.03 & 2.18 & 1.17 \\
\hline $14 \mathrm{H}-1,135-140$ & $\mathrm{Rh}$ & 27.38 & 7.87 & 0.81 & 0.06 & 0.11 & 0.02 & 2.14 & 0.75 \\
\hline $15 \mathrm{H}-1,136-140$ & $\mathrm{Rh}$ & 29.38 & 7.85 & 0.66 & 0.06 & 0.08 & 0.01 & 2.13 & 0.46 \\
\hline $16 \mathrm{H}-1,135-140$ & $\mathrm{Rh}$ & 31.38 & 7.15 & 0.63 & 0.08 & 0.08 & 0.01 & 2.11 & 0.31 \\
\hline $17 \mathrm{H}-1,135-140$ & $\mathrm{Rh}$ & 33.38 & 5.61 & 0.70 & 0.12 & 0.10 & 0.01 & 2.06 & 0.28 \\
\hline $18 \mathrm{H}-1,135-140$ & $\mathrm{Rh}$ & 35.38 & 4.82 & 0.65 & 0.13 & 0.10 & 0.01 & 2.05 & 0.24 \\
\hline $19 \mathrm{H}-1,135-140$ & $\mathrm{Rh}$ & 37.38 & 4.06 & 0.63 & 0.17 & 0.12 & 0.01 & 2.07 & 0.30 \\
\hline $20 \mathrm{H}-1,135-140$ & $\mathrm{Rh}$ & 39.38 & 3.43 & 0.59 & 0.18 & 0.13 & 0.01 & 2.20 & 0.35 \\
\hline $21 \mathrm{H}-1,135-140$ & $\mathrm{Rh}$ & 41.38 & 2.83 & 0.56 & 0.22 & 0.15 & 0.01 & 2.26 & 0.38 \\
\hline $22 \mathrm{H}-1,135-140$ & $\mathrm{Rh}$ & 43.38 & 2.29 & 0.56 & 0.27 & 0.17 & 0.01 & 2.30 & 0.45 \\
\hline $23 \mathrm{H}-1,135-140$ & $\mathrm{Rh}$ & 45.38 & 1.82 & 0.55 & 0.32 & 0.18 & 0.01 & 2.40 & 0.41 \\
\hline $24 \mathrm{H}-1,135-140$ & $\mathrm{Rh}$ & 47.38 & 1.46 & 0.55 & 0.09 & 0.20 & 0.01 & - & 0.27 \\
\hline $25 \mathrm{H}-1,135-140$ & $\mathrm{Rh}$ & 49.38 & 1.16 & 0.60 & 0.41 & 0.21 & 0.01 & 2.25 & 0.30 \\
\hline $26 \mathrm{H}-1,135-140$ & $\mathrm{Rh}$ & 51.38 & 0.89 & 0.66 & 0.44 & 0.21 & 0.01 & 2.58 & 0.31 \\
\hline $27 \mathrm{H}-1,135-140$ & $\mathrm{Rh}$ & 53.38 & 0.65 & 0.83 & 0.53 & 0.23 & 0.01 & 2.88 & 0.44 \\
\hline $28 \mathrm{H}-1,135-140$ & $\mathrm{Rh}$ & 55.88 & 0.94 & 0.51 & 0.29 & 0.12 & 0.00 & 2.33 & 0.50 \\
\hline $29 \mathrm{H}-1,135-140$ & $\mathrm{Rh}$ & 59.18 & 0.30 & 1.26 & 0.57 & 0.23 & 0.01 & 4.08 & 0.91 \\
\hline $30 \mathrm{H}-1,135-140$ & $\mathrm{Rh}$ & 62.48 & 0.16 & 1.99 & 0.78 & 0.28 & 0.02 & 5.88 & 2.26 \\
\hline $31 \mathrm{H}-1,134-140$ & $\mathrm{Rh}$ & 65.77 & 1.02 & 0.36 & 0.12 & 0.04 & 0.00 & 2.03 & 0.33 \\
\hline $32 \mathrm{H}-1,135-140$ & $\mathrm{Rh}$ & 69.08 & 0.34 & 0.78 & 0.26 & 0.07 & 0.01 & 3.21 & 0.88 \\
\hline $33 \mathrm{H}-1,135-140$ & $\mathrm{Rh}$ & 72.38 & 0.09 & 2.55 & 0.74 & 0.16 & 0.02 & 7.65 & 3.06 \\
\hline $34 \mathrm{H}-1,135-140$ & $\mathrm{Rh}$ & 75.68 & 0.17 & 6.03 & 1.21 & 0.56 & 0.04 & 4.65 & 3.55 \\
\hline $35 \mathrm{H}-1,135-140$ & $\mathrm{Rh}$ & 78.98 & 0.07 & 0.82 & 0.31 & 0.00 & 0.03 & - & 1.11 \\
\hline $37 \mathrm{H}-1,135-140$ & $\mathrm{Rh}$ & 85.58 & 0.03 & 5.21 & 1.07 & 0.00 & 0.06 & 18.22 & 9.82 \\
\hline $38 \mathrm{H}-1,135-140$ & $\mathrm{Rh}$ & 88.88 & 0.04 & 3.63 & 0.69 & 0.00 & 0.03 & 13.08 & 7.37 \\
\hline $39 \mathrm{H}-1,135-140$ & $\mathrm{Rh}$ & 92.18 & 0.02 & 8.74 & 1.15 & 0.37 & 0.09 & 26.70 & 29.64 \\
\hline \multicolumn{10}{|l|}{ 347-M0063D- } \\
\hline $1 \mathrm{H}-1,135-140$ & $\mathrm{Rh}$ & 1.38 & 10.42 & 0.88 & 0.02 & 0.11 & 0.03 & 1.70 & 1.17 \\
\hline $1 \mathrm{H}-2,104-109$ & $\mathrm{Rh}$ & 2.57 & 10.68 & 0.84 & 0.02 & 0.11 & 0.02 & 1.77 & 1.16 \\
\hline $2 \mathrm{H}-1,135-140$ & $\mathrm{Rh}$ & 2.88 & 10.67 & 0.89 & 0.02 & 0.12 & 0.03 & 1.80 & 1.21 \\
\hline $2 \mathrm{H}-2,135-140$ & $\mathrm{Rh}$ & 4.38 & 11.86 & 0.72 & 0.02 & 0.09 & 0.02 & 1.87 & 0.96 \\
\hline $3 \mathrm{H}-1,97-102$ & $\mathrm{Rh}$ & 4.50 & 10.32 & 0.84 & 0.02 & 0.11 & 0.03 & 1.82 & 1.24 \\
\hline $3 \mathrm{H}-2,103-1087$ & $\mathrm{Rh}$ & 5.74 & 10.35 & 0.85 & 0.02 & 0.12 & 0.03 & 1.90 & 1.41 \\
\hline $4 \mathrm{H}-1,135-140$ & $\mathrm{Rh}$ & 6.88 & 11.48 & 0.89 & 0.02 & 0.13 & 0.03 & 1.95 & 1.75 \\
\hline $4 \mathrm{H}-2,56-61$ & $\mathrm{Rh}$ & 7.59 & 11.73 & 0.84 & 0.02 & 0.12 & 0.03 & 1.96 & 1.51 \\
\hline $5 \mathrm{H}-1,135-140$ & $\mathrm{Rh}$ & 8.88 & 12.38 & 0.86 & 0.02 & 0.13 & 0.03 & 1.95 & 1.67 \\
\hline $5 \mathrm{H}-2,47-52$ & $\mathrm{Rh}$ & 9.50 & 12.10 & 0.89 & 0.03 & 0.13 & 0.03 & 2.01 & 1.70 \\
\hline $6 \mathrm{H}-1,108-113$ & $\mathrm{Rh}$ & 10.61 & 12.10 & 0.89 & 0.03 & 0.13 & 0.03 & 2.03 & 1.68 \\
\hline $6 \mathrm{H}-2,73-78$ & $\mathrm{Rh}$ & 11.49 & 12.00 & 0.94 & 0.03 & 0.13 & 0.03 & 2.09 & 1.73 \\
\hline 7H-1, $121-126$ & $\mathrm{Rh}$ & 12.74 & 11.87 & 0.91 & 0.03 & 0.13 & 0.03 & 2.12 & 1.75 \\
\hline 7H-2, 92-97 & $\mathrm{Rh}$ & 13.81 & 11.75 & 0.94 & 0.03 & 0.14 & 0.03 & 2.16 & 1.88 \\
\hline $8 \mathrm{H}-1,135-140$ & $\mathrm{Rh}$ & 14.88 & 11.48 & 0.92 & 0.03 & 0.13 & 0.03 & 2.15 & 1.80 \\
\hline $8 \mathrm{H}-2,145-150$ & $\mathrm{Rh}$ & 16.48 & 11.32 & 0.87 & 0.02 & 0.13 & 0.03 & 2.18 & 1.61 \\
\hline $9 \mathrm{H}-1,135-140$ & $\mathrm{Rh}$ & 16.88 & 11.17 & 0.92 & 0.02 & 0.13 & 0.03 & 2.21 & 1.60 \\
\hline $9 \mathrm{H}-2,65-70$ & $\mathrm{Rh}$ & 17.68 & 11.03 & 0.84 & 0.02 & 0.12 & 0.03 & 2.21 & 1.44 \\
\hline
\end{tabular}


Table T9 (continued). (Continued on next page.)

\begin{tabular}{|c|c|c|c|c|c|c|c|c|c|}
\hline $\begin{array}{l}\text { Core, section, } \\
\text { interval }(\mathrm{cm})\end{array}$ & Type & $\begin{array}{l}\text { Depth } \\
\text { (mbsf) }\end{array}$ & $\begin{array}{l}\text { Cl-based } \\
\text { salinity }\end{array}$ & $\begin{array}{c}\mathrm{Na} / \mathrm{Cl} \\
(\mathrm{mM} / \mathrm{mM})\end{array}$ & $\begin{array}{c}\mathrm{Ca} / \mathrm{Cl} \\
(\mathrm{mM} / \mathrm{mM})\end{array}$ & $\begin{array}{c}\mathrm{Mg} / \mathrm{Cl} \\
(\mathrm{mM} / \mathrm{mM})\end{array}$ & $\begin{array}{c}\mathrm{K} / \mathrm{Cl} \\
(\mathrm{mM} / \mathrm{mM})\end{array}$ & $\begin{array}{c}\mathrm{Br} / \mathrm{Cl} \\
(\mu \mathrm{M} / \mathrm{mM})\end{array}$ & $\begin{array}{c}\mathrm{B} / \mathrm{Cl} \\
(\mu \mathrm{M} / \mathrm{mM})\end{array}$ \\
\hline $10 \mathrm{H}-1,120-125$ & $\mathrm{Rh}$ & 18.73 & 10.78 & 0.83 & 0.02 & 0.12 & 0.03 & 2.20 & 1.58 \\
\hline $10 \mathrm{H}-2,135-140$ & $\mathrm{Rh}$ & 20.23 & 10.63 & 0.88 & 0.02 & 0.14 & 0.03 & 2.27 & 1.62 \\
\hline $11 \mathrm{H}-1,91-96$ & $\mathrm{Rh}$ & 20.44 & 9.86 & 0.88 & 0.02 & 0.14 & 0.03 & 2.30 & 1.49 \\
\hline $12 \mathrm{H}-1,135-140$ & $\mathrm{Rh}$ & 22.88 & - & - & - & - & - & - & - \\
\hline $13 \mathrm{H}-1,91-96$ & $\mathrm{Rh}$ & 23.94 & 9.01 & 0.83 & 0.04 & 0.12 & 0.02 & 2.28 & 1.18 \\
\hline $14 \mathrm{H}-1,78-83$ & $\mathrm{Rh}$ & 25.81 & - & - & - & - & - & - & - \\
\hline $15 \mathrm{H}-1,112-117$ & $\mathrm{Rh}$ & 28.15 & 7.53 & 0.79 & 0.07 & 0.11 & 0.02 & 2.23 & 0.60 \\
\hline $16 \mathrm{H}-1,135-140$ & $\mathrm{Rh}$ & 30.38 & 6.55 & 0.77 & 0.09 & 0.10 & 0.01 & 2.19 & 0.44 \\
\hline $17 \mathrm{H}-1,135-140$ & $\mathrm{Rh}$ & 32.38 & 5.97 & 0.69 & 0.11 & 0.09 & 0.01 & 2.18 & 0.33 \\
\hline $18 \mathrm{H}-1,135-140$ & $\mathrm{Rh}$ & 34.38 & 4.99 & 0.65 & 0.13 & 0.10 & 0.01 & 2.17 & 0.22 \\
\hline $19 \mathrm{H}-1,135-140$ & $\mathrm{Rh}$ & 36.38 & 4.14 & 0.65 & 0.15 & 0.11 & 0.01 & 2.06 & 0.32 \\
\hline $20 \mathrm{H}-1,135-140$ & $\mathrm{Rh}$ & 38.38 & 3.67 & 0.58 & 0.18 & 0.12 & 0.01 & 2.10 & 0.29 \\
\hline $21 \mathrm{H}-1,135-140$ & $\mathrm{Rh}$ & 40.38 & 3.02 & 0.57 & 0.22 & 0.14 & 0.01 & 2.16 & 0.34 \\
\hline $22 \mathrm{H}-1,135-140$ & $\mathrm{Rh}$ & 42.38 & 2.58 & 0.55 & 0.24 & 0.16 & 0.01 & 2.21 & 0.42 \\
\hline $23 \mathrm{H}-1,135-140$ & $\mathrm{Rh}$ & 44.38 & 1.99 & 0.52 & 0.30 & 0.17 & 0.01 & 2.29 & 0.41 \\
\hline $24 \mathrm{H}-1,135-140$ & $\mathrm{Rh}$ & 45.88 & 1.76 & 0.48 & 0.21 & 0.17 & 0.01 & 2.36 & 0.41 \\
\hline $25 \mathrm{H}-1,135-140$ & $\mathrm{Rh}$ & 47.88 & 1.37 & 0.55 & 0.38 & 0.20 & 0.01 & 2.46 & 0.33 \\
\hline $26 \mathrm{H}-1,135-140$ & $\mathrm{Rh}$ & 49.88 & 1.08 & 0.61 & 0.44 & 0.21 & 0.01 & 2.61 & 0.24 \\
\hline $27 \mathrm{H}-1,135-140$ & $\mathrm{Rh}$ & 51.88 & 0.90 & 0.71 & 0.46 & 0.21 & 0.01 & 2.70 & 0.38 \\
\hline $28 \mathrm{H}-1,135-140$ & $\mathrm{Rh}$ & 53.88 & 0.64 & 0.78 & 0.52 & 0.22 & 0.01 & 3.07 & 0.23 \\
\hline $30 \mathrm{H}-1,135-140$ & $\mathrm{Rh}$ & 55.58 & 0.47 & 0.99 & 0.60 & 0.25 & 0.02 & 3.45 & 0.68 \\
\hline $31 \mathrm{H}-1,135-140$ & $\mathrm{Rh}$ & 57.58 & 0.38 & 1.11 & 0.57 & 0.24 & 0.01 & 3.84 & 0.88 \\
\hline $32 \mathrm{H}-1,135-140$ & $\mathrm{Rh}$ & 60.08 & 0.21 & 1.69 & 0.71 & 0.27 & 0.01 & 5.20 & 0.96 \\
\hline $33 \mathrm{H}-1,135-140$ & $\mathrm{Rh}$ & 62.58 & 0.17 & 1.90 & 0.73 & 0.27 & 0.01 & 6.19 & 1.32 \\
\hline $34 \mathrm{H}-1,135-140$ & $\mathrm{Rh}$ & 65.08 & 0.18 & 1.79 & 0.68 & 0.21 & 0.01 & 5.25 & 1.48 \\
\hline $36 \mathrm{H}-1,135-140$ & $\mathrm{Rh}$ & 68.98 & 1.28 & 0.50 & 0.17 & 0.06 & 0.00 & 1.89 & 0.20 \\
\hline $37 \mathrm{H}-1,135-140$ & $\mathrm{Rh}$ & 71.68 & 0.04 & 5.00 & 1.35 & 0.28 & 0.04 & 15.50 & 4.09 \\
\hline $38 \mathrm{H}-1,135-140$ & $\mathrm{Rh}$ & 74.98 & 0.06 & 3.41 & 0.87 & 0.12 & 0.02 & 10.83 & 4.12 \\
\hline $39 \mathrm{H}-1,135-140$ & $\mathrm{Rh}$ & 78.28 & 0.20 & 1.38 & 0.40 & 0.07 & 0.01 & 4.08 & 1.23 \\
\hline $40 \mathrm{H}-1,135-140$ & $\mathrm{Rh}$ & 81.58 & 0.03 & 4.52 & 0.96 & 0.00 & 0.05 & 15.88 & 5.66 \\
\hline $41 \mathrm{H}-1,135-140$ & $\mathrm{Rh}$ & 84.88 & 0.09 & 2.07 & 0.51 & 0.00 & 0.03 & 7.05 & 2.98 \\
\hline \multicolumn{10}{|l|}{ 347-M0063E- } \\
\hline $1 \mathrm{H}-1,80-90$ & $\mathrm{Sq}$ & 0.85 & 10.40 & 0.79 & 0.02 & 0.10 & 0.02 & 1.70 & 1.08 \\
\hline $1 \mathrm{H}-2,20-30$ & $\mathrm{Sq}$ & 1.45 & 10.78 & 0.82 & 0.02 & 0.10 & 0.03 & 1.82 & 1.07 \\
\hline $2 \mathrm{H}-1,115-125$ & $\mathrm{Sq}$ & 3.20 & 10.68 & 0.89 & 0.02 & 0.12 & 0.03 & 1.77 & 1.16 \\
\hline $2 \mathrm{H}-2,120-130$ & $\mathrm{Sq}$ & 4.75 & 11.24 & 0.81 & 0.02 & 0.11 & 0.02 & 1.89 & 1.26 \\
\hline $3 \mathrm{H}-1,70-80$ & $\mathrm{Sq}$ & 4.75 & 11.49 & 0.82 & 0.02 & 0.12 & 0.02 & 1.94 & 1.41 \\
\hline $4 \mathrm{H}-2,67-77$ & $\mathrm{Sq}$ & 7.49 & 12.17 & 0.83 & 0.02 & 0.12 & 0.03 & 1.98 & 1.59 \\
\hline $5 \mathrm{H}-1,58-68$ & $\mathrm{sq}$ & 8.63 & 12.14 & 0.84 & 0.02 & 0.12 & 0.03 & 1.97 & 1.54 \\
\hline $5 \mathrm{H}-2,90-90$ & $\mathrm{Sq}$ & - & 12.24 & 0.83 & 0.02 & 0.12 & 0.03 & 2.01 & 1.57 \\
\hline $6 \mathrm{H}-1,98-108$ & $\mathrm{Sq}$ & 11.03 & - & - & - & - & - & - & - \\
\hline $6 \mathrm{H}-2,81-81$ & $\mathrm{Sq}$ & - & 12.30 & - & - & - & - & 2.08 & - \\
\hline $7 \mathrm{H}-1,60-70$ & $\mathrm{Sq}$ & 12.65 & 12.38 & 0.85 & 0.02 & 0.12 & 0.03 & 2.05 & 1.64 \\
\hline 7H-2, 121-121 & $\mathrm{Sq}$ & - & 11.87 & - & - & - & - & 2.12 & - \\
\hline $8 \mathrm{H}-1,90-100$ & $\mathrm{Sq}$ & 14.95 & 12.49 & 0.80 & 0.02 & 0.11 & 0.03 & 2.14 & 1.53 \\
\hline $8 \mathrm{H}-2,60-60$ & $\mathrm{Sq}$ & - & 11.55 & - & - & - & - & 2.16 & - \\
\hline $9 \mathrm{H}-1,84-94$ & $\mathrm{Sq}$ & 16.89 & 11.59 & 0.87 & 0.02 & 0.12 & 0.03 & 2.20 & 1.73 \\
\hline $9 \mathrm{H}-2,100-100$ & $\mathrm{Sq}$ & - & 11.07 & 0.88 & 0.02 & 0.12 & 0.03 & 2.23 & 1.53 \\
\hline $10 \mathrm{H}-1,25-35$ & $\mathrm{Sq}$ & 18.30 & - & - & - & - & - & - & - \\
\hline $10 \mathrm{H}-2,75-75$ & $\mathrm{Sq}$ & - & 10.77 & 0.86 & 0.02 & 0.13 & 0.03 & 2.25 & 1.52 \\
\hline $11 \mathrm{H}-1,90-100$ & $\mathrm{Sq}$ & 20.95 & - & - & - & - & - & - & - \\
\hline $11 \mathrm{H}-2,112-112$ & $\mathrm{Sq}$ & - & 9.67 & 0.86 & 0.02 & 0.13 & 0.03 & 2.28 & 1.41 \\
\hline $12 \mathrm{H}-1,117-127$ & $\mathrm{Sq}$ & 23.22 & 9.78 & 0.83 & 0.03 & 0.12 & 0.03 & 2.29 & 1.24 \\
\hline $13 \mathrm{H}-1,68-78$ & $\mathrm{Sq}$ & 24.73 & 9.19 & 0.83 & 0.04 & 0.12 & 0.03 & 2.25 & 1.09 \\
\hline $14 \mathrm{H}-2,65-75$ & $\mathrm{Sq}$ & 26.90 & - & - & - & - & - & - & - \\
\hline $15 \mathrm{H}-1,57-67$ & $\mathrm{Sq}$ & 28.62 & 7.85 & 0.77 & 0.06 & 0.10 & 0.02 & 2.19 & 0.62 \\
\hline $16 \mathrm{H}-1,114-124$ & $\mathrm{Sq}$ & 31.19 & 6.46 & 0.82 & 0.09 & 0.10 & 0.02 & 2.14 & 0.49 \\
\hline $17 \mathrm{H}-1,111-121$ & $\mathrm{Sq}$ & 33.16 & 6.06 & 0.78 & 0.13 & 0.11 & 0.01 & 2.14 & 0.31 \\
\hline $18 \mathrm{H}-1,106-116$ & $\mathrm{sq}$ & 35.11 & 5.12 & 0.74 & 0.15 & 0.11 & 0.01 & 2.12 & 0.29 \\
\hline $19 \mathrm{H}-1,127-137$ & $\mathrm{sq}$ & 37.32 & 4.14 & 0.64 & 0.16 & 0.11 & 0.01 & 2.22 & 0.26 \\
\hline $20 \mathrm{H}-1,135-145$ & Sq & 39.40 & 3.49 & 0.58 & 0.18 & 0.13 & 0.01 & 2.18 & 0.26 \\
\hline $21 \mathrm{H}-1,83-93$ & $\mathrm{Sq}$ & 40.88 & 3.02 & 0.57 & 0.21 & 0.15 & 0.01 & 2.24 & 0.34 \\
\hline $22 \mathrm{H}-1,135-140$ & $\mathrm{Sq}$ & 43.35 & 2.46 & 0.54 & 0.25 & 0.17 & 0.01 & 2.31 & 0.54 \\
\hline $23 \mathrm{H}-1,135-145$ & $\mathrm{Sq}$ & 45.40 & 1.99 & 0.53 & 0.31 & 0.18 & 0.01 & 2.35 & 0.36 \\
\hline $24 \mathrm{H}-1,115-125$ & $\mathrm{sq}$ & 47.20 & 1.67 & 0.53 & 0.35 & 0.19 & 0.01 & 2.42 & 0.22 \\
\hline $25 \mathrm{H}-1,135-145$ & Sq & 49.40 & 1.25 & 0.59 & 0.43 & 0.22 & 0.01 & 2.62 & 0.24 \\
\hline $26 \mathrm{H}-1,135-145$ & $\mathrm{Sq}$ & 51.40 & 0.90 & 0.69 & 0.48 & 0.24 & 0.01 & 2.83 & 0.27 \\
\hline $27 \mathrm{H}-1,125-135$ & $\mathrm{Sq}$ & 53.30 & 0.59 & 0.88 & 0.58 & 0.26 & 0.01 & 3.36 & 0.34 \\
\hline $28 \mathrm{H}-1,135-145$ & $\mathrm{Sq}$ & 55.40 & 0.55 & 0.91 & 0.58 & 0.26 & 0.01 & 3.42 & 0.40 \\
\hline
\end{tabular}


Table T9 (continued). (Continued on next page.)

\begin{tabular}{|c|c|c|c|c|c|c|c|c|c|}
\hline $\begin{array}{l}\text { Core, section, } \\
\text { interval }(\mathrm{cm})\end{array}$ & Type & $\begin{array}{l}\text { Depth } \\
\text { (mbsf) }\end{array}$ & $\begin{array}{l}\text { Cl-based } \\
\text { salinity }\end{array}$ & $\begin{array}{c}\mathrm{Na} / \mathrm{Cl} \\
(\mathrm{mM} / \mathrm{mM})\end{array}$ & $\begin{array}{c}\mathrm{Ca} / \mathrm{Cl} \\
(\mathrm{mM} / \mathrm{mM})\end{array}$ & $\begin{array}{c}\mathrm{Mg} / \mathrm{Cl} \\
(\mathrm{mM} / \mathrm{mM})\end{array}$ & $\begin{array}{c}\mathrm{K} / \mathrm{Cl} \\
(\mathrm{mM} / \mathrm{mM})\end{array}$ & $\begin{array}{c}\mathrm{Br} / \mathrm{Cl} \\
(\mu \mathrm{M} / \mathrm{mM})\end{array}$ & $\begin{array}{c}\mathrm{B} / \mathrm{Cl} \\
(\mu \mathrm{M} / \mathrm{mM})\end{array}$ \\
\hline $29 \mathrm{H}-1,135-145$ & $\mathrm{Sq}$ & 57.40 & 0.44 & 1.09 & 0.55 & 0.24 & 0.01 & 3.58 & 0.80 \\
\hline $30 \mathrm{H}-1,120-130$ & $\mathrm{Sq}$ & 59.25 & 2.83 & 0.65 & 0.18 & 0.09 & 0.00 & 1.70 & 0.32 \\
\hline $31 \mathrm{H}-1,135-145$ & $\mathrm{Sq}$ & 61.40 & 0.25 & 1.64 & 0.65 & 0.29 & 0.01 & 4.94 & 0.95 \\
\hline $32 \mathrm{H}-1,135-145$ & $\mathrm{Sq}$ & 63.40 & 0.21 & 1.80 & 0.61 & 0.25 & 0.02 & 5.15 & 1.32 \\
\hline $33 \mathrm{H}-1,125-135$ & $\mathrm{Sq}$ & 65.30 & 0.12 & 2.79 & 0.83 & 0.33 & 0.02 & 7.40 & 2.06 \\
\hline $34 \mathrm{H}-1,135-145$ & $\mathrm{Sq}$ & 67.40 & 0.37 & 1.34 & 0.37 & 0.14 & 0.01 & 3.33 & 0.85 \\
\hline $35 \mathrm{H}-1,135-145$ & $\mathrm{Sq}$ & 69.40 & 1.85 & 0.64 & 0.21 & 0.08 & 0.00 & 1.76 & 0.26 \\
\hline $36 \mathrm{H}-1,125-135$ & $\mathrm{Sq}$ & 71.30 & 0.05 & 5.54 & 1.10 & 0.28 & 0.05 & 14.32 & 4.42 \\
\hline $37 \mathrm{H}-1,135-145$ & $\mathrm{Sq}$ & 73.40 & 0.05 & 5.05 & 0.62 & 0.14 & 0.05 & 12.84 & 3.93 \\
\hline $39 \mathrm{H}-1,135-145$ & $\mathrm{Sq}$ & 76.70 & 0.06 & 3.46 & 0.70 & 0.09 & 0.03 & 10.08 & 3.58 \\
\hline $40 \mathrm{H}-1,125-135$ & $\mathrm{Sq}$ & 79.90 & 0.06 & 3.23 & 0.48 & 0.01 & 0.03 & 9.17 & 3.07 \\
\hline $41 \mathrm{H}-1,125-135$ & $\mathrm{Sq}$ & 83.20 & 0.03 & 5.27 & 0.49 & 0.00 & 0.06 & 16.75 & 7.50 \\
\hline $42 \mathrm{H}-1,135-145$ & $\mathrm{Sq}$ & 86.60 & 0.04 & 4.74 & 0.51 & 0.00 & 0.04 & 14.70 & 6.19 \\
\hline $43 \mathrm{H}-1,125-135$ & $\mathrm{Sq}$ & 89.80 & 0.12 & 1.68 & 0.39 & 0.00 & 0.02 & 5.83 & 3.12 \\
\hline \multicolumn{10}{|l|}{ 347-M0063E- } \\
\hline 7H-1, 36-41 & $\mathrm{Rh}$ & 12.39 & 10.53 & 0.85 & 0.02 & 0.12 & 0.03 & 1.97 & 1.45 \\
\hline 7H-2, 92-97 & $\mathrm{Rh}$ & 14.20 & 11.81 & 0.88 & 0.02 & 0.12 & 0.03 & 2.10 & 1.41 \\
\hline $8 \mathrm{H}-2,30-35$ & $\mathrm{Rh}$ & 15.74 & 11.55 & 0.88 & 0.02 & 0.13 & 0.03 & 2.16 & 1.52 \\
\hline $9 \mathrm{H}-1,21-26$ & $\mathrm{Rh}$ & 16.24 & 9.83 & 0.88 & 0.02 & 0.12 & 0.03 & 2.05 & 1.49 \\
\hline $9 \mathrm{H}-2,70-75$ & $\mathrm{Rh}$ & 18.03 & 11.09 & 0.90 & 0.02 & 0.14 & 0.03 & 2.21 & 1.53 \\
\hline $10 \mathrm{H}-1,6-6$ & $\mathrm{Rh}$ & 18.06 & 8.61 & 0.84 & 0.02 & 0.11 & 0.03 & 2.02 & 1.18 \\
\hline $11 \mathrm{H}-2,39-44$ & $\mathrm{Rh}$ & 20.42 & 9.13 & 0.87 & 0.02 & 0.13 & 0.03 & 2.15 & 1.42 \\
\hline $12 \mathrm{H}-1,56-61$ & $\mathrm{Rh}$ & 22.59 & 9.43 & 0.92 & 0.02 & 0.13 & 0.03 & 2.22 & 0.99 \\
\hline $11 \mathrm{H}-2,82-87$ & $\mathrm{Rh}$ & 22.15 & - & - & - & - & - & - & - \\
\hline $13 \mathrm{H}-1,43-48$ & $\mathrm{Rh}$ & 24.46 & 9.28 & 0.92 & 0.04 & 0.13 & 0.03 & 2.28 & 1.07 \\
\hline $14 \mathrm{H}-3,88-93$ & $\mathrm{Rh}$ & 28.06 & 7.91 & 0.89 & 0.07 & 0.11 & 0.02 & 2.22 & 0.69 \\
\hline $15 \mathrm{H}-2,106-111$ & $\mathrm{Rh}$ & 30.09 & 7.03 & - & - & - & - & 2.19 & - \\
\hline $16 \mathrm{H}-1,88-93$ & $\mathrm{Rh}$ & 30.91 & 6.84 & - & - & - & - & 2.04 & - \\
\hline $17 \mathrm{H}-1,54-59$ & $\mathrm{Rh}$ & 32.57 & 6.12 & 0.80 & 0.09 & 0.09 & 0.01 & 2.01 & 0.31 \\
\hline $18 \mathrm{H}-1,46-51$ & $\mathrm{Rh}$ & 34.49 & 6.03 & 0.77 & 0.10 & 0.09 & 0.01 & 1.87 & 0.34 \\
\hline $19 \mathrm{H}-1,100-105$ & $\mathrm{Rh}$ & 37.03 & 4.18 & 0.67 & 0.17 & 0.12 & 0.01 & 2.19 & 0.29 \\
\hline $20 \mathrm{H}-1,80-85$ & $\mathrm{Rh}$ & 38.83 & 3.65 & 0.66 & 0.19 & 0.13 & 0.01 & 2.15 & 0.36 \\
\hline $21 \mathrm{H}-1,23-28$ & $\mathrm{Rh}$ & 40.26 & 4.46 & 0.72 & 0.16 & 0.12 & 0.01 & 1.77 & 0.41 \\
\hline $22 \mathrm{H}-1,116-121$ & $\mathrm{Rh}$ & 43.19 & 2.89 & 0.56 & 0.23 & 0.15 & 0.01 & 2.20 & 0.46 \\
\hline $23 \mathrm{H}-1,81-86$ & $\mathrm{Rh}$ & 44.84 & 2.13 & 0.58 & 0.30 & 0.17 & 0.01 & 2.30 & 0.44 \\
\hline $24 \mathrm{H}-1,56-61$ & $\mathrm{Rh}$ & 46.59 & 3.61 & 0.70 & 0.21 & 0.12 & 0.01 & 1.76 & 0.37 \\
\hline $25 \mathrm{H}-1,110-115$ & $\mathrm{Rh}$ & 49.13 & 2.75 & - & - & - & - & 1.89 & - \\
\hline $26 \mathrm{H}-1,80-85$ & $\mathrm{Rh}$ & 50.83 & 1.12 & - & - & - & - & 2.57 & - \\
\hline $27 \mathrm{H}-1,65-70$ & $\mathrm{Rh}$ & 52.68 & 0.66 & - & - & - & - & 3.06 & - \\
\hline $28 \mathrm{H}-1,111-116$ & $\mathrm{Rh}$ & 55.14 & 1.62 & - & - & - & - & 2.04 & 0.37 \\
\hline $29 \mathrm{H}-1,79-84$ & $\mathrm{Rh}$ & 56.82 & 2.67 & - & - & - & - & 1.75 & 0.34 \\
\hline $30 \mathrm{H}-1,59-64$ & $\mathrm{Rh}$ & 58.62 & 2.71 & - & - & - & - & 1.72 & 0.35 \\
\hline $31 \mathrm{H}-1,106-111$ & $\mathrm{Rh}$ & 61.09 & - & - & - & - & - & - & - \\
\hline $32 \mathrm{H}-1,77-82$ & $\mathrm{Rh}$ & 62.80 & 3.69 & - & - & - & - & 1.60 & 0.31 \\
\hline $33 \mathrm{H}-1,63-86$ & $\mathrm{Rh}$ & 64.75 & 2.91 & - & - & - & - & 1.66 & 0.34 \\
\hline $34 \mathrm{H}-1,109-114$ & $\mathrm{Rh}$ & 67.12 & 2.95 & - & - & - & - & 1.65 & 0.32 \\
\hline $35 \mathrm{H}-1,80-85$ & $\mathrm{Rh}$ & 68.83 & 3.23 & - & - & - & - & 1.62 & 0.35 \\
\hline $36 \mathrm{H}-1,64-69$ & $\mathrm{Rh}$ & 70.67 & 1.04 & - & - & - & - & 2.03 & 0.64 \\
\hline $37 \mathrm{H}-1,110-115$ & $\mathrm{Rh}$ & 73.13 & 0.16 & - & - & - & - & 5.31 & 6.29 \\
\hline $39 \mathrm{H}-1,81-86$ & $\mathrm{Rh}$ & 76.14 & 0.26 & - & - & - & - & 3.62 & 2.36 \\
\hline $40 \mathrm{H}-1,65-70$ & $\mathrm{Rh}$ & 79.28 & 0.08 & - & - & - & - & 8.48 & 7.57 \\
\hline $41 \mathrm{H}-1,99-104$ & $\mathrm{Rh}$ & 82.92 & 0.10 & - & - & - & - & 6.87 & 6.51 \\
\hline $42 \mathrm{H}-1,80-85$ & $\mathrm{Rh}$ & 86.03 & 0.12 & - & - & - & - & 5.67 & 5.64 \\
\hline $43 \mathrm{H}-1,65-70$ & $\mathrm{Rh}$ & 89.18 & 0.13 & - & - & - & - & 5.44 & 5.16 \\
\hline $44 \mathrm{H}-1,63-68$ & $\mathrm{Rh}$ & 92.46 & 0.50 & - & - & - & - & 2.22 & - \\
\hline \multicolumn{10}{|l|}{ 347-M0063E- } \\
\hline $21 \mathrm{H}-2,10-15$ & $\mathrm{Rh}$ & 41.21 & 2.77 & 0.66 & 0.25 & 0.17 & 0.01 & 2.25 & 0.52 \\
\hline $22 \mathrm{H}-2,70-75$ & $\mathrm{Rh}$ & 44.23 & 2.34 & 0.70 & 0.31 & 0.19 & 0.01 & 2.25 & 0.53 \\
\hline $23 \mathrm{H}-2,7-12$ & $\mathrm{Rh}$ & 45.60 & 1.74 & 0.62 & 0.35 & 0.19 & 0.01 & 2.37 & 0.47 \\
\hline $24 \mathrm{H}-2,120-125$ & $\mathrm{Rh}$ & 48.73 & 1.26 & 0.69 & 0.43 & 0.21 & 0.01 & 2.58 & 0.45 \\
\hline $25 \mathrm{H}-2,40-45$ & $\mathrm{Rh}$ & 49.93 & 1.18 & 0.63 & 0.43 & 0.20 & 0.01 & 2.59 & 0.38 \\
\hline $26 \mathrm{H}-2,130-135$ & $\mathrm{Rh}$ & 52.83 & 0.85 & - & - & - & - & 2.72 & 0.52 \\
\hline $27 \mathrm{H}-2,35-40$ & $\mathrm{Rh}$ & 53.88 & 4.67 & - & - & - & - & 1.61 & 0.25 \\
\hline $28 \mathrm{H}-2,70-75$ & $\mathrm{Rh}$ & 56.23 & 0.69 & - & - & - & - & 2.85 & 0.67 \\
\hline $29 \mathrm{H}-2,90-95$ & $\mathrm{Rh}$ & 58.43 & 0.45 & - & - & - & - & 3.37 & 1.10 \\
\hline $30 \mathrm{H}-2,110-115$ & $\mathrm{Rh}$ & 60.63 & 0.46 & - & - & - & - & 3.30 & 1.54 \\
\hline $31 \mathrm{H}-2,60-65$ & $\mathrm{Rh}$ & 62.13 & 0.31 & - & - & - & - & 3.98 & 1.29 \\
\hline $32 \mathrm{H}-2,102-107$ & $\mathrm{Rh}$ & 64.55 & 0.28 & - & - & - & - & 4.01 & 1.66 \\
\hline $33 \mathrm{H}-2,95-100$ & $\mathrm{Rh}$ & 66.48 & 0.25 & - & - & - & - & 4.00 & 2.02 \\
\hline
\end{tabular}


Table T9 (continued).

\begin{tabular}{|c|c|c|c|c|c|c|c|c|c|}
\hline $\begin{array}{l}\text { Core, section, } \\
\text { interval }(\mathrm{cm})\end{array}$ & Type & $\begin{array}{l}\text { Depth } \\
\text { (mbsf) }\end{array}$ & $\begin{array}{l}\text { Cl-based } \\
\text { salinity }\end{array}$ & $\begin{array}{c}\mathrm{Na} / \mathrm{Cl} \\
(\mathrm{mM} / \mathrm{mM})\end{array}$ & $\begin{array}{c}\mathrm{Ca} / \mathrm{Cl} \\
(\mathrm{mM} / \mathrm{mM})\end{array}$ & $\begin{array}{c}\mathrm{Mg} / \mathrm{Cl} \\
(\mathrm{mM} / \mathrm{mM})\end{array}$ & $\begin{array}{c}\mathrm{K} / \mathrm{Cl} \\
(\mathrm{mM} / \mathrm{mM})\end{array}$ & $\begin{array}{c}\mathrm{Br} / \mathrm{Cl} \\
(\mu \mathrm{M} / \mathrm{mM})\end{array}$ & $\begin{array}{c}\mathrm{B} / \mathrm{Cl} \\
(\mu \mathrm{M} / \mathrm{mM})\end{array}$ \\
\hline $34 \mathrm{H}-2,70-75$ & $\mathrm{Rh}$ & 68.23 & 0.47 & - & - & - & - & 2.82 & 1.11 \\
\hline $35 \mathrm{H}-2,90-95$ & $\mathrm{Rh}$ & 70.43 & 0.14 & - & - & - & - & 5.79 & 3.31 \\
\hline $36 \mathrm{H}-2,93-93$ & $\mathrm{Rh}$ & 72.43 & 0.25 & - & - & - & - & 3.85 & 2.11 \\
\hline
\end{tabular}

$-=$ no data are reported for samples with insufficient pore water volumes. $\mathrm{Rh}=$ Rhizon sample, $\mathrm{Sq}=$ squeezed sample

Table T10. Concentration of methane in interstitial water, Site M0063.

\begin{tabular}{lrr}
\hline $\begin{array}{c}\text { Core, section, } \\
\text { interval (cm) }\end{array}$ & $\begin{array}{r}\text { Depth } \\
\text { (mbsf) }\end{array}$ & \multicolumn{1}{c}{$\begin{array}{c}\mathrm{CH}_{4} \\
(\mathrm{mM})\end{array}$} \\
\hline $347-\mathrm{M} 0063 \mathrm{~A}-$ & & \\
2H-2, 145-150 & 1.62 & 7.09 \\
$2 \mathrm{H}-3,145-150$ & 3.12 & 9.29 \\
$3 \mathrm{H}-2,136-141$ & 4.99 & 4.61 \\
$4 \mathrm{H}-1,145-150$ & 8.08 & 3.20 \\
$5 \mathrm{H}-2,145-150$ & 11.83 & 2.33 \\
$6 \mathrm{H}-1,105-110$ & 14.28 & 3.19 \\
$7 \mathrm{H}-1,145-150$ & 17.98 & 42.32 \\
$8 \mathrm{H}-1,145-150$ & 20.98 & 3.08 \\
$9 \mathrm{H}-1,145-150$ & 24.28 & 1.70 \\
$10 \mathrm{H}-1,137-142$ & 27.50 & 16.43 \\
$11 \mathrm{H}-1,144-149$ & 30.87 & 4.67 \\
$12 \mathrm{H}-1,145-150$ & 34.18 & 6.23 \\
$13 \mathrm{H}-1,145-150$ & 37.48 & 8.29 \\
$14 \mathrm{H}-1,145-150$ & 40.78 & 10.99 \\
$15 \mathrm{H}-1,145-150$ & 44.08 & 8.19 \\
$16 \mathrm{H}-1,145-150$ & 47.38 & 9.40 \\
$17 \mathrm{H}-1,145-150$ & 50.68 & 6.33 \\
$18 \mathrm{H}-1,145-150$ & 53.98 & 3.79 \\
$20 \mathrm{H}-1,145-150$ & 60.58 & 1.22 \\
$21 \mathrm{H}-1,145-150$ & 63.88 & 0.57 \\
$22 \mathrm{H}-1,144-149$ & 67.17 & 0.28 \\
$23 \mathrm{H}-1,144-149$ & 70.47 & 0.13 \\
$24 \mathrm{H}-1,145-150$ & 73.78 & 0.05 \\
$25 \mathrm{H}-1,145-150$ & 77.08 & 0.03 \\
$26 \mathrm{H}-1,145-150$ & 80.38 & 0.01 \\
$27 \mathrm{H}-1,145-150$ & 83.68 & 0.01 \\
$28 \mathrm{H}-1,145-150$ & 86.98 & 0.00 \\
$29 \mathrm{H}-1,145-150$ & 90.28 & 0.00 \\
$30 \mathrm{H}-1,135-140$ & 93.48 & 0.00 \\
$31 \mathrm{H}-1,145-150$ & 95.38 & 0.00 \\
\hline
\end{tabular}


Table T11. Total carbon (TC), total organic carbon (TOC), total inorganic carbon (TIC), and total sulfur (TS) in sediment, Site M0063. (Continued on next page.)

\begin{tabular}{|c|c|c|c|c|c|}
\hline $\begin{array}{l}\text { Core, section, } \\
\text { interval }(\mathrm{cm})\end{array}$ & $\begin{array}{l}\text { Depth } \\
\text { (mbsf) }\end{array}$ & $\begin{array}{c}\mathrm{TC} \\
(\mathrm{wt} \%)\end{array}$ & $\begin{array}{l}\text { TOC } \\
\text { (wt\%) }\end{array}$ & $\begin{array}{c}\mathrm{TIC} \\
(w t \%)\end{array}$ & $\begin{array}{c}\text { TS } \\
(w t \%)\end{array}$ \\
\hline \multicolumn{6}{|l|}{ 347-M0063A- } \\
\hline 1P-1, 18-18.5 & 0.18 & 2.13 & 1.84 & 0.28 & 0.43 \\
\hline $2 \mathrm{H}-3,39-40.5$ & 2.03 & 2.37 & 2.09 & 0.28 & 0.77 \\
\hline $3 \mathrm{H}-2,30-31.5$ & 3.90 & 0.49 & 0.41 & 0.08 & 0.09 \\
\hline $3 \mathrm{H}-2,30-31$ & 3.90 & 9.10 & 3.44 & 5.67 & 1.84 \\
\hline $3 \mathrm{H}-3,111.5-113$ & 6.13 & 4.85 & 2.30 & 2.55 & 2.98 \\
\hline $4 \mathrm{H}-2,21-22$ & 8.31 & 1.91 & 1.67 & 0.24 & 0.78 \\
\hline $5 \mathrm{H}-1,19-20$ & 10.09 & 1.72 & 1.60 & 0.12 & 0.75 \\
\hline $5 \mathrm{H}-2,141-142$ & 11.76 & 1.76 & 1.53 & 0.23 & 0.95 \\
\hline $6 \mathrm{H}-1,27-28$ & 13.47 & 2.04 & 1.76 & 0.27 & 0.92 \\
\hline $6 \mathrm{H}-2,63-64$ & 14.93 & 1.89 & 1.54 & 0.36 & 0.73 \\
\hline $7 \mathrm{H}-1,69-70$ & 17.19 & 1.57 & 1.45 & 0.12 & 0.96 \\
\hline 7H-2, 105-106 & 19.05 & 3.69 & 2.17 & 1.52 & 2.11 \\
\hline $8 \mathrm{H}-1,102-103$ & 20.52 & 6.30 & 4.23 & 2.08 & 3.61 \\
\hline $8 \mathrm{H}-2,71-72$ & 21.71 & 7.78 & 6.41 & 1.36 & 2.85 \\
\hline $9 \mathrm{H}-1,34-35$ & 23.14 & 7.09 & 5.33 & 1.76 & 2.37 \\
\hline $9 \mathrm{H}-2,42-43$ & 24.72 & 6.89 & 5.12 & 1.78 & 2.08 \\
\hline $10 \mathrm{H}-1,66-67$ & 26.76 & 1.51 & 1.45 & 0.06 & 0.27 \\
\hline $10 \mathrm{H}-3,10-11$ & 29.12 & 0.54 & 0.35 & 0.19 & 0.07 \\
\hline $11 \mathrm{H}-1,107-108$ & 30.47 & 0.50 & 0.34 & 0.16 & 0.07 \\
\hline $11 \mathrm{H}-2,107-108$ & 31.96 & 0.54 & 0.31 & 0.23 & 0.08 \\
\hline $12 \mathrm{H}-1,66-67$ & 33.36 & 0.35 & 0.20 & 0.16 & 0.08 \\
\hline $12 \mathrm{H}-2,135-136$ & 35.55 & 0.45 & 0.38 & 0.06 & 0.10 \\
\hline $13 \mathrm{H}-1,110-111$ & 37.10 & 0.74 & 0.54 & 0.19 & 0.10 \\
\hline $13 \mathrm{H}-1,122-123$ & 37.22 & 0.63 & 0.55 & 0.09 & 0.13 \\
\hline $13 \mathrm{H}-2,120-121$ & 38.70 & 0.41 & 0.24 & 0.17 & 0.08 \\
\hline $13 \mathrm{H}-3,50-51$ & 39.50 & 0.37 & 0.18 & 0.20 & 0.08 \\
\hline $14 \mathrm{H}-2,40-41$ & 41.20 & 0.35 & 0.29 & 0.05 & 0.08 \\
\hline $15 \mathrm{H}-1,41-42$ & 43.01 & 0.88 & 0.71 & 0.18 & 0.14 \\
\hline $15 \mathrm{H}-2,85-86$ & 44.95 & 0.77 & 0.55 & 0.21 & 0.09 \\
\hline $16 \mathrm{H}-1,136-137$ & 47.26 & 0.70 & 0.55 & 0.14 & 0.08 \\
\hline $16 \mathrm{H}-2,120-121$ & 48.60 & 0.56 & 0.47 & 0.09 & 0.10 \\
\hline $17 \mathrm{H}-2,100-101$ & 51.70 & 0.60 & 0.50 & 0.10 & 0.08 \\
\hline $18 \mathrm{H}-2,100-101$ & 55.00 & 0.34 & 0.28 & 0.06 & 0.08 \\
\hline $19 \mathrm{H}-1,120-121$ & 57.00 & 1.13 & 0.42 & 0.71 & 0.28 \\
\hline $20 \mathrm{H}-1,71-72$ & 59.81 & 0.27 & 0.25 & 0.02 & 0.08 \\
\hline $21 \mathrm{H}-1,98-100$ & 63.38 & 0.37 & 0.29 & 0.09 & 0.08 \\
\hline $22 \mathrm{H}-1,100-101$ & 66.70 & 0.26 & 0.20 & 0.06 & 0.08 \\
\hline $23 \mathrm{H}-1,70-71$ & 69.70 & 0.23 & 0.19 & 0.04 & 0.08 \\
\hline $24 \mathrm{H}-1,72-73$ & 73.02 & 0.27 & 0.16 & 0.11 & 0.08 \\
\hline $25 \mathrm{H}-1,70-71$ & 76.30 & 0.27 & 0.16 & 0.11 & 0.08 \\
\hline $26 \mathrm{H}-1,110-111$ & 80.00 & 0.27 & 0.24 & 0.04 & 0.08 \\
\hline 27H-1, 97-98 & 83.17 & 0.27 & 0.14 & 0.13 & 0.08 \\
\hline $28 \mathrm{H}-1,77-78$ & 86.27 & 0.24 & 0.14 & 0.10 & 0.08 \\
\hline $29 \mathrm{H}-1,137-138$ & 90.17 & 0.53 & 0.15 & 0.38 & 0.09 \\
\hline $30 \mathrm{H}-1,46-47$ & 92.56 & 0.18 & 0.14 & 0.04 & 0.10 \\
\hline $31 \mathrm{H}-1,47-48$ & 94.37 & 0.11 & 0.06 & 0.06 & 0.13 \\
\hline $36 \mathrm{H}-1,5-6$ & 101.85 & 0.72 & 0.42 & 0.30 & 0.11 \\
\hline \multicolumn{6}{|l|}{ 347-M0063B- } \\
\hline $1 \mathrm{H}-1,74-75$ & 0.74 & 7.10 & 3.30 & 3.80 & 1.83 \\
\hline $2 \mathrm{H}-1,89-90$ & 2.89 & 2.75 & 2.38 & 0.37 & 1.20 \\
\hline $3 \mathrm{H}-1,139-140$ & 5.39 & 3.75 & 3.22 & 0.54 & 1.29 \\
\hline $4 \mathrm{H}-1,65-66$ & 6.65 & 7.39 & 3.22 & 4.17 & 2.92 \\
\hline $5 \mathrm{H}-1,135-137$ & 9.35 & 5.38 & 2.81 & 2.56 & 2.31 \\
\hline $6 \mathrm{H}-1,138-139$ & 11.38 & 1.83 & 1.64 & 0.20 & 1.06 \\
\hline 7H-1, 128-129 & 13.28 & 1.82 & 1.51 & 0.31 & 0.80 \\
\hline $8 \mathrm{H}-1,50-51$ & 15.50 & 1.93 & 1.68 & 0.24 & 1.15 \\
\hline $9 \mathrm{H}-1,44-45$ & 17.44 & 1.92 & 1.66 & 0.26 & 1.00 \\
\hline $10 \mathrm{H}-1,112-113$ & 20.12 & 4.11 & 2.16 & 1.95 & 2.42 \\
\hline $11 \mathrm{H}-1,47-48$ & 21.47 & 6.23 & 3.56 & 2.67 & 3.22 \\
\hline $12 \mathrm{H}-2,111-112$ & 25.61 & 1.68 & 1.44 & 0.24 & 1.72 \\
\hline $13 \mathrm{H}-2,90-91$ & 27.37 & 3.37 & 2.83 & 0.54 & 1.77 \\
\hline $14 \mathrm{H}-2,92-93$ & 29.42 & 0.61 & 0.39 & 0.22 & 0.12 \\
\hline \multicolumn{6}{|l|}{ 347-M0063C- } \\
\hline 1H-1, 91-92 & 0.91 & 2.29 & 2.08 & 0.21 & 1.27 \\
\hline $2 \mathrm{H}-1,125-126$ & 3.25 & 2.86 & 2.70 & 0.16 & 0.92 \\
\hline $3 \mathrm{H}-1,74.5-75.5$ & 4.75 & 6.40 & 3.57 & 2.83 & 3.15 \\
\hline
\end{tabular}

\begin{tabular}{|c|c|c|c|c|c|}
\hline $\begin{array}{l}\text { Core, section, } \\
\text { interval }(\mathrm{cm})\end{array}$ & $\begin{array}{l}\text { Depth } \\
\text { (mbsf) }\end{array}$ & $\begin{array}{c}\mathrm{TC} \\
\text { (wt\%) }\end{array}$ & $\begin{array}{l}\text { TOC } \\
\text { (wt\%) }\end{array}$ & $\begin{array}{c}\mathrm{TIC} \\
(\mathrm{wt} \%)\end{array}$ & $\begin{array}{c}\text { TS } \\
\text { (wt\%) }\end{array}$ \\
\hline $4 \mathrm{H}-1,146-147$ & 7.46 & 2.69 & 1.91 & 0.77 & 1.16 \\
\hline $6 \mathrm{H}-1,105-106$ & 11.05 & 2.02 & 1.76 & 0.26 & 0.77 \\
\hline $7 \mathrm{H}-1,66-67$ & 12.66 & 1.91 & 1.80 & 0.12 & 1.24 \\
\hline $8 \mathrm{H}-2,54-55$ & 15.98 & 2.10 & 1.76 & 0.35 & 0.96 \\
\hline $9 \mathrm{H}-1,51-52$ & 16.51 & 1.73 & 1.61 & 0.11 & 1.01 \\
\hline $10 \mathrm{H}-1,113-114$ & 19.13 & 3.02 & 2.22 & 0.79 & 2.37 \\
\hline $11 \mathrm{H}-2,55-56$ & 22.05 & 6.58 & 3.60 & 2.98 & 3.45 \\
\hline $12 \mathrm{H}-2,22-23$ & 23.72 & 6.84 & 5.45 & 1.40 & 2.35 \\
\hline $13 \mathrm{H}-1,113-114$ & 25.13 & 4.92 & 2.69 & 2.23 & 1.48 \\
\hline $13 \mathrm{H}-2,56-57$ & 25.98 & 2.15 & 1.96 & 0.19 & 1.63 \\
\hline $15 \mathrm{H}-2,39-40$ & 25.89 & 0.51 & 0.46 & 0.05 & 0.10 \\
\hline $16 \mathrm{H}-1,50-51$ & 30.50 & 0.90 & 0.85 & 0.06 & 0.11 \\
\hline $17 \mathrm{H}-1,70-71$ & 32.70 & 0.48 & 0.37 & 0.11 & 0.10 \\
\hline $18 \mathrm{H}-1,90-91$ & 34.90 & 0.51 & 0.46 & 0.05 & 0.11 \\
\hline $19 \mathrm{H}-2,33-35$ & 37.83 & 0.45 & 0.34 & 0.11 & 0.13 \\
\hline $20 \mathrm{H}-1,70-71$ & 38.70 & 0.55 & 0.50 & 0.05 & 0.11 \\
\hline $21 \mathrm{H}-1,97-98$ & 40.97 & 0.52 & 0.48 & 0.04 & 0.11 \\
\hline $22 \mathrm{H}-2,79-80$ & 44.29 & 0.66 & 0.58 & 0.08 & 0.12 \\
\hline $23 \mathrm{H}-1,24-25$ & 44.24 & 0.64 & 0.56 & 0.09 & 0.11 \\
\hline $24 \mathrm{H}-1,100-101$ & 47.00 & 0.67 & 0.61 & 0.06 & 0.11 \\
\hline $25 \mathrm{H}-1,108-109$ & 49.08 & 0.51 & 0.44 & 0.08 & 0.09 \\
\hline $26 \mathrm{H}-1,105-106$ & 51.05 & 0.31 & 0.26 & 0.05 & 0.10 \\
\hline $27 \mathrm{H}-1,84-85$ & 52.84 & 0.34 & 0.29 & 0.05 & 0.10 \\
\hline $28 \mathrm{H}-1,90-91$ & 55.40 & 0.40 & 0.35 & 0.05 & 0.10 \\
\hline $29 \mathrm{H}-1,117-118$ & 58.97 & 0.29 & 0.24 & 0.05 & 0.08 \\
\hline $30 \mathrm{H}-1,111-112$ & 62.21 & 0.40 & 0.25 & 0.16 & 0.09 \\
\hline $31 \mathrm{H}-1,130-131$ & 65.70 & 0.27 & 0.20 & 0.06 & 0.09 \\
\hline $32 \mathrm{H}-1,127-129$ & 68.97 & 0.35 & 0.19 & 0.16 & 0.10 \\
\hline $33 \mathrm{H}-2,80-81$ & 73.30 & 0.24 & 0.13 & 0.11 & 0.10 \\
\hline $34 \mathrm{H}-1,15-16$ & 74.45 & 0.25 & 0.14 & 0.10 & 0.09 \\
\hline $35 \mathrm{H}-2,3-4$ & 79.13 & 0.24 & 0.12 & 0.12 & 0.10 \\
\hline $36 \mathrm{H}-1,15-16$ & 81.05 & 0.23 & 0.11 & 0.13 & 0.10 \\
\hline $37 \mathrm{H}-2,75-77$ & 86.45 & 0.37 & 0.12 & 0.25 & 0.10 \\
\hline $38 \mathrm{H}-1,15-16$ & 87.65 & 0.22 & 0.12 & 0.10 & 0.10 \\
\hline $39 \mathrm{H}-1,8-9$ & 90.88 & 0.22 & 0.07 & 0.14 & 0.11 \\
\hline \multicolumn{6}{|l|}{ 347-M0063D- } \\
\hline $1 \mathrm{H}-3,32-33$ & 3.01 & 2.30 & 2.03 & 0.28 & 0.60 \\
\hline $2 \mathrm{H}-2,65-66$ & 3.65 & 2.63 & 2.44 & 0.19 & 0.76 \\
\hline $3 \mathrm{H}-1,42-43$ & 3.92 & 2.71 & 2.52 & 0.19 & 1.13 \\
\hline $3 \mathrm{H}-2,55-56$ & 5.16 & 8.69 & 6.70 & 1.99 & 2.57 \\
\hline $4 \mathrm{H}-1,74-75$ & 6.24 & 5.78 & 3.26 & 2.52 & 2.48 \\
\hline $5 \mathrm{H}-1,140-141$ & 8.90 & 2.03 & 1.93 & 0.10 & 1.26 \\
\hline $6 \mathrm{H}-1,86-87$ & 10.36 & 2.32 & 1.67 & 0.65 & 0.94 \\
\hline 7H-1, 107-108 & 12.57 & 2.05 & 1.76 & 0.28 & 0.77 \\
\hline $8 \mathrm{H}-1,108-109$ & 14.58 & 1.92 & 1.72 & 0.20 & 1.01 \\
\hline $9 \mathrm{H}-1,82-83$ & 16.32 & 1.98 & 1.73 & 0.25 & 1.07 \\
\hline $10 \mathrm{H}-1,127-128$ & 18.77 & 2.01 & 1.87 & 0.14 & 1.64 \\
\hline $11 \mathrm{H}-1,64-65$ & 20.14 & 9.74 & 8.65 & 1.09 & 3.65 \\
\hline $12 \mathrm{H}-1,138-139$ & 22.88 & 7.50 & 6.11 & 1.39 & 3.13 \\
\hline $13 \mathrm{H}-2,142-143$ & 25.48 & 3.69 & 3.10 & 0.59 & 2.51 \\
\hline $14 \mathrm{H}-1,48-49$ & 25.48 & 2.64 & 2.28 & 0.36 & 1.53 \\
\hline $15 \mathrm{H}-2,42-43$ & 28.69 & 0.58 & 0.37 & 0.21 & 0.11 \\
\hline $16 \mathrm{H}-2,27-28$ & 30.77 & 0.49 & 0.37 & 0.12 & 0.09 \\
\hline 17H-1, 70-71 & 31.70 & 0.49 & 0.35 & 0.14 & 0.09 \\
\hline $18 \mathrm{H}-2,22-23$ & 34.72 & 0.61 & 0.45 & 0.16 & 0.10 \\
\hline $19 \mathrm{H}-1,128-129$ & 36.28 & 0.74 & 0.62 & 0.12 & 0.11 \\
\hline $19 \mathrm{H}-2,80-81$ & 37.30 & 0.30 & 0.27 & 0.03 & 0.11 \\
\hline $20 \mathrm{H}-1,113-114$ & 38.13 & 0.53 & 0.45 & 0.08 & 0.10 \\
\hline $21 \mathrm{H}-1,66-67$ & 39.66 & 0.55 & 0.45 & 0.09 & 0.10 \\
\hline $22 \mathrm{H}-1,93-94$ & 41.93 & 0.62 & 0.53 & 0.09 & 0.12 \\
\hline $23 \mathrm{H}-1,80-81$ & 43.80 & 0.55 & 0.48 & 0.07 & 0.10 \\
\hline $24 \mathrm{H}-1,123-124$ & 45.73 & 0.63 & 0.53 & 0.10 & 0.11 \\
\hline $25 \mathrm{H}-1,112-113$ & 47.62 & 0.65 & 0.50 & 0.15 & 0.10 \\
\hline $26 \mathrm{H}-1,126-127$ & 49.76 & 0.49 & 0.40 & 0.09 & 0.09 \\
\hline 27H-1, 90-91 & 51.40 & 0.56 & 0.48 & 0.08 & 0.10 \\
\hline $28 \mathrm{H}-1,125-126$ & 53.75 & 0.53 & 0.47 & 0.06 & 0.10 \\
\hline $30 \mathrm{H}-1,120-121$ & 55.40 & 0.38 & 0.34 & 0.04 & 0.09 \\
\hline
\end{tabular}


Table T11 (continued).

\begin{tabular}{|c|c|c|c|c|c|}
\hline $\begin{array}{l}\text { Core, section, } \\
\text { interval }(\mathrm{cm})\end{array}$ & $\begin{array}{l}\text { Depth } \\
\text { (mbsf) }\end{array}$ & $\begin{array}{c}\text { TC } \\
\text { (wt\%) }\end{array}$ & $\begin{array}{l}\text { TOC } \\
\text { (wt\%) }\end{array}$ & $\begin{array}{c}\text { TIC } \\
\text { (wt\%) }\end{array}$ & $\begin{array}{c}\text { TS } \\
\text { (wt\%) }\end{array}$ \\
\hline $31 \mathrm{H}-1,115-116$ & 57.35 & 0.31 & 0.26 & 0.05 & 0.09 \\
\hline $32 \mathrm{H}-1,115-116$ & 59.85 & 0.28 & 0.24 & 0.04 & 0.09 \\
\hline $33 \mathrm{H}-1,112-113$ & 62.32 & 0.34 & 0.24 & 0.10 & 0.10 \\
\hline $34 \mathrm{H}-1,89-90$ & 64.59 & 0.63 & 0.23 & 0.40 & 0.10 \\
\hline $36 \mathrm{H}-1,117-118$ & 68.77 & 0.26 & 0.17 & 0.09 & 0.09 \\
\hline $37 \mathrm{H}-1,117-118$ & 71.47 & 0.20 & 0.12 & 0.08 & 0.10 \\
\hline $38 \mathrm{H}-1,100-101$ & 74.60 & 0.25 & 0.14 & 0.11 & 0.09 \\
\hline $39 \mathrm{H}-1,95-96$ & 77.85 & 0.25 & 0.14 & 0.11 & 0.09 \\
\hline $40 \mathrm{H}-1,58-59$ & 80.78 & 0.29 & 0.13 & 0.16 & 0.10 \\
\hline $41 \mathrm{H}-1,83-85$ & 84.33 & 0.22 & 0.10 & 0.12 & 0.10 \\
\hline \multicolumn{6}{|l|}{ 347-M0064E- } \\
\hline $5 \mathrm{H}-1,1-2$ & 8.01 & 2.60 & 1.93 & 0.67 & 0.92 \\
\hline $7 \mathrm{H}-1,0-2$ & 12.00 & 2.67 & 1.72 & 0.95 & 1.11 \\
\hline $9 \mathrm{H}-1,1-2$ & 16.01 & 2.21 & 1.72 & 0.49 & 0.98 \\
\hline $11 \mathrm{H}-1,1-2$ & 20.01 & 4.25 & 2.97 & 1.28 & 2.85 \\
\hline $11 \mathrm{H}-2,41-42$ & 21.71 & 9.28 & 7.22 & 2.07 & 2.34 \\
\hline $12 \mathrm{H}-1,49-50$ & 22.49 & 7.90 & 6.22 & 1.68 & 2.06 \\
\hline $13 \mathrm{H}-1,39-40$ & 24.39 & 4.28 & 2.91 & 1.37 & 1.40 \\
\hline $15 \mathrm{H}-1,12-13$ & 28.12 & 1.23 & 1.18 & 0.05 & 0.15 \\
\hline $15 \mathrm{H}-2,62-63$ & 29.62 & 0.53 & 0.53 & 0.00 & 0.09 \\
\hline $16 \mathrm{H}-2,52-53$ & 32.02 & 0.46 & 0.39 & 0.07 & 0.09 \\
\hline 17H-1, 19-20 & 32.19 & 0.45 & 0.36 & 0.08 & - \\
\hline $18 \mathrm{H}-2,46-47$ & 35.92 & 0.36 & 0.36 & 0.00 & 0.10 \\
\hline $19 \mathrm{H}-1,62-63$ & 36.62 & 0.53 & 0.51 & 0.02 & 0.09 \\
\hline $20 \mathrm{H}-2,100-101$ & 40.50 & 0.50 & 0.50 & 0.00 & 0.09 \\
\hline $21 \mathrm{H}-2,58-59$ & 41.66 & 0.65 & 0.54 & 0.11 & 0.11 \\
\hline $22 \mathrm{H}-2,100-101$ & 44.50 & 0.77 & 0.56 & 0.21 & 0.09 \\
\hline $23 \mathrm{H}-2,91-92$ & 46.41 & 0.62 & 0.49 & 0.13 & 0.09 \\
\hline $24 \mathrm{H}-1,50-51$ & 46.50 & 0.62 & 0.53 & 0.09 & 0.10 \\
\hline $25 \mathrm{H}-1,108-109$ & 49.08 & 0.64 & 0.56 & 0.08 & 0.09 \\
\hline $26 \mathrm{H}-1,77-78$ & 50.77 & 0.49 & 0.46 & 0.03 & 0.09 \\
\hline $27 \mathrm{H}-2,65-66$ & 54.15 & 0.57 & 0.54 & 0.04 & 0.09 \\
\hline $28 \mathrm{H}-2,100-101$ & 56.50 & 0.28 & 0.28 & 0.00 & 0.08 \\
\hline $30 \mathrm{H}-2,125-116$ & 60.65 & 0.27 & 0.26 & 0.01 & 0.08 \\
\hline $31 \mathrm{H}-2,107-108$ & 62.57 & 0.33 & 0.28 & 0.05 & 0.07 \\
\hline $33 \mathrm{H}-1,72-73$ & 64.72 & 0.39 & 0.26 & 0.13 & 0.09 \\
\hline $35 \mathrm{H}-2,77-79$ & 70.27 & 0.25 & 0.24 & 0.01 & 0.08 \\
\hline $37 \mathrm{H}-2,48-49$ & 73.98 & 0.22 & 0.17 & 0.05 & 0.09 \\
\hline $41 \mathrm{H}-2,68-69$ & 84.08 & 0.41 & 0.16 & 0.25 & 0.08 \\
\hline $43 \mathrm{H}-2,48-49$ & 90.48 & 0.28 & 0.13 & 0.15 & 0.09 \\
\hline $44 \mathrm{H}-1,25.5-26.5$ & 92.06 & 0.14 & 0.10 & 0.04 & 0.10 \\
\hline
\end{tabular}


Table T12. Samples taken for cell counts by flow cytometry and acridine orange direct count (AODC), Hole M0063E.

\begin{tabular}{|c|c|c|c|}
\hline $\begin{array}{l}\text { Core, section, } \\
\text { interval }(\mathrm{cm})\end{array}$ & $\begin{array}{l}\text { Top depth } \\
\text { (mbsf) }\end{array}$ & $\begin{array}{c}\text { Cytometer } \\
\text { counts } \\
\left(\log \text { cells } / \mathrm{cm}^{3}\right)\end{array}$ & $\begin{array}{c}\text { AODC } \\
\left(\log \text { cells } / \mathrm{cm}^{3}\right)\end{array}$ \\
\hline \multicolumn{4}{|l|}{ 347-M0063E- } \\
\hline $1 \mathrm{H}-2,2$ & 1.22 & 8.57 & 9.82 \\
\hline $1 \mathrm{H}-2,145$ & 2.65 & 8.90 & 9.94 \\
\hline $2 \mathrm{H}-2,2$ & 3.52 & 8.65 & 9.68 \\
\hline $2 \mathrm{H}-2,145$ & 4.95 & 9.00 & 9.86 \\
\hline $3 \mathrm{H}-2,2$ & 5.30 & 8.67 & \\
\hline $3 \mathrm{H}-2,67$ & 5.95 & 8.38 & \\
\hline $4 \mathrm{H}-2,92$ & 7.69 & 8.58 & \\
\hline $5 \mathrm{H}-2,2$ & 9.14 & 8.82 & \\
\hline $5 \mathrm{H}-2,110$ & 10.22 & 8.90 & \\
\hline $6 \mathrm{H}-2,3$ & 11.38 & 8.82 & \\
\hline $6 \mathrm{H}-2,92$ & 12.27 & 8.54 & \\
\hline $7 \mathrm{H}-2,2$ & 13.27 & 8.70 & \\
\hline $8 \mathrm{H}-2,3$ & 15.44 & 9.15 & 9.67 \\
\hline $8 \mathrm{H}-2,73$ & 16.14 & 8.79 & \\
\hline $9 \mathrm{H}-2,3$ & 17.33 & 8.78 & \\
\hline $9 \mathrm{H}-2,111$ & 18.41 & 8.68 & \\
\hline $10 \mathrm{H}-2,3$ & 19.03 & 8.52 & 9.36 \\
\hline $10 \mathrm{H}-2,86$ & 19.86 & 8.64 & 9.40 \\
\hline $11 \mathrm{H}-2,3$ & 21.33 & 8.46 & \\
\hline $11 \mathrm{H}-2,118$ & 22.48 & 8.84 & \\
\hline $12 \mathrm{H}-2,79$ & 23.53 & 8.65 & \\
\hline $12 \mathrm{H}-2,3$ & 24.29 & 8.58 & 9.26 \\
\hline $13 \mathrm{H}-2,3$ & 25.03 & 8.49 & 9.13 \\
\hline $13 \mathrm{H}-2,62$ & 25.62 & 8.54 & \\
\hline $14 \mathrm{H}-2,3$ & 27.18 & 8.75 & \\
\hline $14 \mathrm{H}-3,107$ & 28.22 & 8.61 & 9.22 \\
\hline $15 \mathrm{H}-2,3$ & 29.03 & 8.66 & 8.83 \\
\hline $15 \mathrm{H}-2,125$ & 30.25 & 8.52 & 8.81 \\
\hline $16 \mathrm{H}-2,3$ & 31.53 & 8.39 & 8.96 \\
\hline $16 \mathrm{H}-2,141$ & 32.91 & 8.11 & \\
\hline $17 \mathrm{H}-2,3$ & 33.40 & 8.40 & 8.70 \\
\hline $17 \mathrm{H}-2,138$ & 34.75 & 8.20 & \\
\hline $18 \mathrm{H}-2,3$ & 35.49 & 8.13 & 8.14 \\
\hline $18 \mathrm{H}-2,3$ & 36.62 & 8.38 & \\
\hline $19 \mathrm{H}-2,3$ & 37.53 & 8.24 & 8.58 \\
\hline
\end{tabular}

\begin{tabular}{|c|c|c|c|}
\hline $\begin{array}{l}\text { Core, section, } \\
\text { interval }(\mathrm{cm})\end{array}$ & $\begin{array}{l}\text { Top depth } \\
\text { (mbsf) }\end{array}$ & $\begin{array}{c}\text { Cytometer } \\
\text { counts } \\
\left(\log \text { cells } / \mathrm{cm}^{3}\right)\end{array}$ & $\begin{array}{c}\text { AODC } \\
\left(\log \text { cells } / \mathrm{cm}^{3}\right)\end{array}$ \\
\hline $19 \mathrm{H}-2,103$ & 38.53 & 8.10 & \\
\hline $20 \mathrm{H}-2,3$ & 39.50 & 8.14 & 8.93 \\
\hline $20 \mathrm{H}-2,133$ & 40.83 & 8.25 & \\
\hline $21 \mathrm{H}-2,2$ & 41.10 & 8.24 & 7.79 \\
\hline $21 \mathrm{H}-2,148$ & 42.00 & 8.48 & \\
\hline $22 \mathrm{H}-2,2$ & 43.52 & 8.28 & 8.34 \\
\hline $22 \mathrm{H}-2,148$ & 44.92 & 8.16 & \\
\hline $23 \mathrm{H}-2,2$ & 45.52 & 8.11 & \\
\hline $23 \mathrm{H}-2,144$ & 46.45 & 8.09 & \\
\hline $24 \mathrm{H}-2,2$ & 47.52 & 8.11 & 8.17 \\
\hline $24 \mathrm{H}-2,145$ & 48.95 & 8.11 & \\
\hline $25 \mathrm{H}-2,2$ & 49.52 & 8.18 & 7.90 \\
\hline $25 \mathrm{H}-2,145$ & 50.97 & 8.06 & \\
\hline $26 \mathrm{H}-2,2$ & 51.52 & 8.05 & 8.33 \\
\hline $26 \mathrm{H}-2,145$ & 52.95 & 7.98 & \\
\hline $27 \mathrm{H}-2,47$ & 53.97 & 8.01 & 8.22 \\
\hline $28 \mathrm{H}-2,2$ & 55.52 & 8.15 & 8.45 \\
\hline $29 \mathrm{H}-2,2$ & 57.52 & 8.05 & 8.35 \\
\hline $30 \mathrm{H}-2,2$ & 59.52 & 8.41 & 8.47 \\
\hline $31 \mathrm{H}-2,2$ & 61.53 & 8.02 & \\
\hline $32 \mathrm{H}-2,3$ & 63.53 & 7.97 & 7.88 \\
\hline $33 \mathrm{H}-2,3$ & 65.53 & 7.99 & \\
\hline $34 \mathrm{H}-2,3$ & 67.53 & 7.92 & \\
\hline $35 \mathrm{H}-2,3$ & 69.53 & 8.08 & 8.17 \\
\hline $36 \mathrm{H}-2,2$ & 69.53 & 8.11 & \\
\hline $36 \mathrm{H}-2,2$ & 71.52 & & 7.51 \\
\hline $37 \mathrm{H}-2,2$ & 73.52 & 7.87 & \\
\hline $39 \mathrm{H}-2,2$ & 76.82 & 8.00 & 7.82 \\
\hline $40 \mathrm{H}-2,2$ & 80.12 & 7.97 & \\
\hline $41 \mathrm{H}-2,2$ & 83.42 & 7.80 & 7.84 \\
\hline $42 \mathrm{H}-2,32$ & 87.02 & 8.07 & 7.69 \\
\hline $43 \mathrm{H}-2,3$ & 90.02 & 7.93 & \\
\hline
\end{tabular}

Respective count data are presented in the last two columns in logarithmic format. 
Table T13. Drilling fluid contamination, Hole M0063E. (Continued on next page.)

\begin{tabular}{|c|c|c|c|c|}
\hline Core & $\begin{array}{l}\text { Depth } \\
\text { (mbsf) }\end{array}$ & $\begin{array}{l}\text { PFC } \\
(\mathrm{g} / \mathrm{L})\end{array}$ & $\begin{array}{l}\text { LF fraction } \\
\text { in sample }\end{array}$ & $\begin{array}{l}\text { Contaminant } \\
\left(\text { cells } / \mathrm{cm}^{3}\right)\end{array}$ \\
\hline \multicolumn{5}{|c|}{ 347-M0063E- } \\
\hline \multicolumn{5}{|c|}{ Core interior } \\
\hline $1 \mathrm{H}$ & 1.15 & BD & NA & NA \\
\hline $2 \mathrm{H}$ & 3.45 & BD & NA & NA \\
\hline $3 \mathrm{H}$ & 5.23 & 1.75E-09 & $6.41 \mathrm{E}-03$ & $1.30 \mathrm{E}+04$ \\
\hline $4 \mathrm{H}$ & 6.72 & $3.58 \mathrm{E}-09$ & $3.50 \mathrm{E}-02$ & $7.10 \mathrm{E}+04$ \\
\hline $5 \mathrm{H}$ & 9.07 & $7.61 \mathrm{E}-10$ & $3.49 \mathrm{E}-05$ & $7.09 \mathrm{E}+01$ \\
\hline $6 \mathrm{H}$ & 11.30 & 3.09E-09 & $2.72 \mathrm{E}-04$ & $5.53 \mathrm{E}+02$ \\
\hline $7 \mathrm{H}$ & 13.20 & $2.29 \mathrm{E}-09$ & $2.70 \mathrm{E}-03$ & $5.49 E+03$ \\
\hline $9 \mathrm{H}$ & 17.25 & $1.81 \mathrm{E}-09$ & $2.02 \mathrm{E}-04$ & $4.11 \mathrm{E}+02$ \\
\hline $10 \mathrm{H}$ & 18.30 & 1.50E-09 & $2.70 \mathrm{E}-05$ & $5.48 \mathrm{E}+01$ \\
\hline $11 \mathrm{H}$ & 21.25 & 1.00E-09 & 8.47E-05 & $1.72 \mathrm{E}+02$ \\
\hline $12 \mathrm{H}$ & 23.45 & $6.69 \mathrm{E}-10$ & $4.24 \mathrm{E}-06$ & $8.60 \mathrm{E}+00$ \\
\hline $13 \mathrm{H}$ & 24.95 & 1.39E-08 & $7.83 \mathrm{E}-04$ & $1.59 \mathrm{E}+03$ \\
\hline $14 \mathrm{H}$ & 27.10 & $4.08 \mathrm{E}-09$ & 4.17E-04 & $8.47 \mathrm{E}+02$ \\
\hline $15 \mathrm{H}$ & 28.95 & $1.21 \mathrm{E}-09$ & $6.63 \mathrm{E}-04$ & $1.35 \mathrm{E}+03$ \\
\hline $16 \mathrm{H}$ & 31.45 & BD & NA & NA \\
\hline $17 \mathrm{H}$ & 33.32 & $\mathrm{BD}$ & NA & NA \\
\hline $18 \mathrm{H}$ & 35.44 & $1.01 \mathrm{E}-08$ & $1.21 \mathrm{E}-03$ & $2.45 \mathrm{E}+03$ \\
\hline $19 \mathrm{H}$ & 37.45 & $6.97 \mathrm{E}-09$ & $1.05 \mathrm{E}-03$ & $2.14 \mathrm{E}+03$ \\
\hline $20 \mathrm{H}$ & 39.45 & 4.00E-09 & $1.06 \mathrm{E}-03$ & $2.16 \mathrm{E}+03$ \\
\hline $21 \mathrm{H}$ & 41.03 & $8.86 \mathrm{E}-10$ & $6.75 \mathrm{E}-04$ & $1.37 \mathrm{E}+03$ \\
\hline $22 \mathrm{H}$ & 43.45 & 1.50E-09 & $9.76 \mathrm{E}-05$ & $1.98 \mathrm{E}+02$ \\
\hline $23 \mathrm{H}$ & 45.45 & $7.90 \mathrm{E}-10$ & $6.83 \mathrm{E}-05$ & $1.39 \mathrm{E}+02$ \\
\hline $24 \mathrm{H}$ & 47.45 & $5.99 \mathrm{E}-09$ & $6.53 \mathrm{E}-04$ & $1.33 \mathrm{E}+03$ \\
\hline $25 \mathrm{H}$ & 49.45 & $4.85 \mathrm{E}-10$ & $2.84 \mathrm{E}-05$ & $5.77 \mathrm{E}+01$ \\
\hline $26 \mathrm{H}$ & 51.45 & 1.79E-09 & $7.63 \mathrm{E}-05$ & $1.55 \mathrm{E}+02$ \\
\hline $27 \mathrm{H}$ & 53.45 & $5.92 \mathrm{E}-10$ & $5.09 \mathrm{E}-05$ & $1.03 \mathrm{E}+02$ \\
\hline $28 \mathrm{H}$ & 55.45 & $6.41 \mathrm{E}-10$ & $8.26 \mathrm{E}-05$ & $1.68 \mathrm{E}+02$ \\
\hline $29 \mathrm{H}$ & 57.45 & $3.10 \mathrm{E}-09$ & $7.72 \mathrm{E}-04$ & $1.57 \mathrm{E}+03$ \\
\hline $30 \mathrm{H}$ & 59.45 & 9.07E-07 & $3.92 \mathrm{E}-02$ & $7.96 \mathrm{E}+04$ \\
\hline $31 \mathrm{H}$ & 61.45 & $2.70 \mathrm{E}-06$ & $2.40 \mathrm{E}+00$ & $4.88 \mathrm{E}+06$ \\
\hline $32 \mathrm{H}$ & 63.45 & 7.07E-09 & $4.18 \mathrm{E}-03$ & $8.49 E+03$ \\
\hline $34 \mathrm{H}$ & 67.45 & $7.08 \mathrm{E}-09$ & $3.23 \mathrm{E}-03$ & $6.56 \mathrm{E}+03$ \\
\hline $36 \mathrm{H}$ & 71.45 & $1.34 \mathrm{E}-09$ & $2.36 \mathrm{E}-03$ & $4.79 \mathrm{E}+03$ \\
\hline $39 \mathrm{H}$ & 76.75 & $2.11 \mathrm{E}-09$ & $7.86 \mathrm{E}-04$ & $1.60 \mathrm{E}+03$ \\
\hline $40 \mathrm{H}$ & 80.05 & 8.95E-09 & $1.23 \mathrm{E}-02$ & $2.50 \mathrm{E}+04$ \\
\hline $41 \mathrm{H}$ & 83.35 & $6.80 \mathrm{E}-10$ & $3.50 \mathrm{E}-05$ & $7.11 \mathrm{E}+01$ \\
\hline $42 \mathrm{H}$ & 86.65 & $1.12 \mathrm{E}-08$ & $3.66 \mathrm{E}-02$ & $7.43 \mathrm{E}+04$ \\
\hline \multicolumn{5}{|c|}{ Core halfway } \\
\hline $1 \mathrm{H}$ & 1.15 & $4.52 \mathrm{E}-10$ & $3.80 \mathrm{E}-03$ & $7.72 \mathrm{E}+03$ \\
\hline $2 \mathrm{H}$ & 3.45 & $1.71 \mathrm{E}-09$ & $8.69 \mathrm{E}-03$ & $1.76 \mathrm{E}+04$ \\
\hline $3 \mathrm{H}$ & 5.23 & 7.27E-10 & $2.66 \mathrm{E}-03$ & $5.40 \mathrm{E}+03$ \\
\hline $4 \mathrm{H}$ & 6.72 & $9.25 \mathrm{E}-10$ & $9.04 \mathrm{E}-03$ & $1.83 \mathrm{E}+04$ \\
\hline $5 \mathrm{H}$ & 9.07 & $2.14 \mathrm{E}-09$ & $9.82 \mathrm{E}-05$ & $1.99 \mathrm{E}+02$ \\
\hline $6 \mathrm{H}$ & 11.30 & $1.89 \mathrm{E}-09$ & $1.66 \mathrm{E}-04$ & $3.38 \mathrm{E}+02$ \\
\hline $7 \mathrm{H}$ & 13.20 & $5.60 \mathrm{E}-10$ & $6.60 \mathrm{E}-04$ & $1.34 \mathrm{E}+03$ \\
\hline $9 \mathrm{H}$ & 17.25 & 1.33E-09 & $1.49 \mathrm{E}-04$ & $3.02 \mathrm{E}+02$ \\
\hline $10 \mathrm{H}$ & 18.30 & $1.14 \mathrm{E}-09$ & $2.06 \mathrm{E}-05$ & $4.19 \mathrm{E}+01$ \\
\hline $11 \mathrm{H}$ & 21.25 & 1.90E-09 & $1.60 \mathrm{E}-04$ & $3.25 \mathrm{E}+02$ \\
\hline $12 \mathrm{H}$ & 23.45 & $6.26 \mathrm{E}-10$ & $3.96 \mathrm{E}-06$ & $8.04 \mathrm{E}+00$ \\
\hline $13 \mathrm{H}$ & 24.95 & $2.13 \mathrm{E}-08$ & $1.19 \mathrm{E}-03$ & $2.42 \mathrm{E}+03$ \\
\hline $14 \mathrm{H}$ & 27.10 & $6.64 \mathrm{E}-10$ & $6.81 \mathrm{E}-05$ & $1.38 \mathrm{E}+02$ \\
\hline $15 \mathrm{H}$ & 28.95 & $6.52 \mathrm{E}-10$ & $3.57 \mathrm{E}-04$ & $7.25 \mathrm{E}+02$ \\
\hline $16 \mathrm{H}$ & 31.45 & Lost & NA & NA \\
\hline $17 \mathrm{H}$ & 33.32 & $3.36 \mathrm{E}-09$ & $2.04 \mathrm{E}-04$ & $4.13 \mathrm{E}+02$ \\
\hline $18 \mathrm{H}$ & 35.44 & 6.62E-09 & $7.88 \mathrm{E}-04$ & $1.60 \mathrm{E}+03$ \\
\hline $19 \mathrm{H}$ & 37.45 & $6.53 \mathrm{E}-09$ & $9.85 \mathrm{E}-04$ & $2.00 \mathrm{E}+03$ \\
\hline $20 \mathrm{H}$ & 39.45 & $1.84 \mathrm{E}-08$ & $4.91 \mathrm{E}-03$ & $9.96 \mathrm{E}+03$ \\
\hline $21 \mathrm{H}$ & 41.03 & $9.58 \mathrm{E}-10$ & 7.30E-04 & $1.48 \mathrm{E}+03$ \\
\hline $22 \mathrm{H}$ & 43.45 & $4.98 \mathrm{E}-10$ & $3.24 \mathrm{E}-05$ & $6.58 \mathrm{E}+01$ \\
\hline $23 \mathrm{H}$ & 45.45 & 1.82E-06 & $1.58 \mathrm{E}-01$ & $3.20 \mathrm{E}+05$ \\
\hline $24 \mathrm{H}$ & 47.45 & $3.10 \mathrm{E}-10$ & $3.38 \mathrm{E}-05$ & $6.86 \mathrm{E}+01$ \\
\hline $25 \mathrm{H}$ & 49.45 & $3.25 \mathrm{E}-08$ & $1.91 \mathrm{E}-03$ & $3.87 \mathrm{E}+03$ \\
\hline $26 \mathrm{H}$ & 51.45 & BD & NA & NA \\
\hline $27 \mathrm{H}$ & 53.45 & $5.73 \mathrm{E}-09$ & $4.92 \mathrm{E}-04$ & $9.99 \mathrm{E}+02$ \\
\hline $28 \mathrm{H}$ & 55.45 & BD & NA & NA \\
\hline $29 \mathrm{H}$ & 57.45 & & NA & \\
\hline
\end{tabular}

\begin{tabular}{|c|c|c|c|c|}
\hline Core & $\begin{array}{l}\text { Depth } \\
\text { (mbsf) }\end{array}$ & $\begin{array}{l}\text { PFC } \\
(\mathrm{g} / \mathrm{L})\end{array}$ & $\begin{array}{l}\text { LF fraction } \\
\text { in sample }\end{array}$ & $\begin{array}{c}\text { Contaminant } \\
\left(\text { cells } / \mathrm{cm}^{3}\right)\end{array}$ \\
\hline $30 \mathrm{H}$ & 59.45 & $4.29 \mathrm{E}-08$ & $1.85 \mathrm{E}-03$ & $3.76 \mathrm{E}+03$ \\
\hline $31 \mathrm{H}$ & 61.45 & $3.42 \mathrm{E}-08$ & $3.04 \mathrm{E}-02$ & $6.17 E+04$ \\
\hline $32 \mathrm{H}$ & 63.45 & $2.89 \mathrm{E}-09$ & $1.71 \mathrm{E}-03$ & $3.47 \mathrm{E}+03$ \\
\hline $34 \mathrm{H}$ & 67.45 & $1.48 \mathrm{E}-08$ & $6.77 \mathrm{E}-03$ & $1.37 \mathrm{E}+04$ \\
\hline $36 \mathrm{H}$ & 71.45 & $2.18 \mathrm{E}-10$ & $3.83 \mathrm{E}-04$ & $7.78 \mathrm{E}+02$ \\
\hline $39 \mathrm{H}$ & 76.75 & $6.81 \mathrm{E}-10$ & $2.54 \mathrm{E}-04$ & $5.16 \mathrm{E}+02$ \\
\hline $40 \mathrm{H}$ & 80.05 & $2.46 \mathrm{E}-09$ & $3.39 \mathrm{E}-03$ & $6.88 \mathrm{E}+03$ \\
\hline $41 \mathrm{H}$ & 83.35 & $8.42 \mathrm{E}-09$ & $4.34 \mathrm{E}-04$ & $8.81 \mathrm{E}+02$ \\
\hline $42 \mathrm{H}$ & 86.65 & $8.65 \mathrm{E}-09$ & $2.84 \mathrm{E}-02$ & $5.76 \mathrm{E}+04$ \\
\hline \multicolumn{5}{|c|}{ Core exterior } \\
\hline $1 \mathrm{H}$ & 1.15 & $6.79 \mathrm{E}-10$ & $5.71 \mathrm{E}-03$ & $1.16 \mathrm{E}+04$ \\
\hline $2 \mathrm{H}$ & 3.45 & $5.98 \mathrm{E}-10$ & $3.04 \mathrm{E}-03$ & $6.17 \mathrm{E}+03$ \\
\hline $3 \mathrm{H}$ & 5.23 & $3.42 \mathrm{E}-07$ & $1.25 \mathrm{E}+00$ & $2.54 \mathrm{E}+06$ \\
\hline $4 \mathrm{H}$ & 6.72 & $2.58 \mathrm{E}-08$ & $2.52 \mathrm{E}-01$ & $5.11 \mathrm{E}+05$ \\
\hline $5 \mathrm{H}$ & 9.07 & $4.26 \mathrm{E}-08$ & $1.95 \mathrm{E}-03$ & $3.96 \mathrm{E}+03$ \\
\hline $6 \mathrm{H}$ & 11.30 & $5.30 \mathrm{E}-08$ & 4.67E-03 & $9.48 \mathrm{E}+03$ \\
\hline $7 \mathrm{H}$ & 13.20 & $1.33 \mathrm{E}-08$ & $1.57 \mathrm{E}-02$ & $3.19 \mathrm{E}+04$ \\
\hline $9 \mathrm{H}$ & 17.25 & $1.63 \mathrm{E}-07$ & $1.82 \mathrm{E}-02$ & $3.70 \mathrm{E}+04$ \\
\hline $10 \mathrm{H}$ & 18.30 & $3.20 \mathrm{E}-06$ & $5.78 \mathrm{E}-02$ & $1.17 \mathrm{E}+05$ \\
\hline $11 \mathrm{H}$ & 21.25 & $1.39 \mathrm{E}-08$ & $1.17 \mathrm{E}-03$ & $2.38 \mathrm{E}+03$ \\
\hline $12 \mathrm{H}$ & 23.45 & $1.66 \mathrm{E}-07$ & $1.05 \mathrm{E}-03$ & $2.14 \mathrm{E}+03$ \\
\hline $13 \mathrm{H}$ & 24.95 & $2.48 \mathrm{E}-08$ & $1.40 \mathrm{E}-03$ & $2.83 \mathrm{E}+03$ \\
\hline $14 \mathrm{H}$ & 27.10 & $7.22 \mathrm{E}-09$ & $7.40 \mathrm{E}-04$ & $1.50 \mathrm{E}+03$ \\
\hline $15 \mathrm{H}$ & 28.95 & $9.12 \mathrm{E}-09$ & $4.99 \mathrm{E}-03$ & $1.01 \mathrm{E}+04$ \\
\hline $16 \mathrm{H}$ & 31.45 & $1.49 \mathrm{E}-08$ & $4.99 \mathrm{E}-03$ & $1.01 \mathrm{E}+04$ \\
\hline $17 \mathrm{H}$ & 33.32 & $9.20 \mathrm{E}-09$ & 5.57E-04 & $1.13 \mathrm{E}+03$ \\
\hline $18 \mathrm{H}$ & 35.44 & $1.71 \mathrm{E}-08$ & $2.04 \mathrm{E}-03$ & $4.14 \mathrm{E}+03$ \\
\hline $19 \mathrm{H}$ & 37.45 & $1.62 \mathrm{E}-09$ & $2.45 \mathrm{E}-04$ & $4.97 \mathrm{E}+02$ \\
\hline $20 \mathrm{H}$ & 39.45 & $9.59 \mathrm{E}-10$ & $2.55 \mathrm{E}-04$ & $5.18 \mathrm{E}+02$ \\
\hline $21 \mathrm{H}$ & 41.03 & $1.79 \mathrm{E}-07$ & $1.36 \mathrm{E}-01$ & $2.77 \mathrm{E}+05$ \\
\hline $22 \mathrm{H}$ & 43.45 & $4.33 \mathrm{E}-08$ & $2.82 \mathrm{E}-03$ & $5.72 \mathrm{E}+03$ \\
\hline $23 \mathrm{H}$ & 45.45 & $6.02 \mathrm{E}-09$ & $5.20 \mathrm{E}-04$ & $1.06 \mathrm{E}+03$ \\
\hline $24 \mathrm{H}$ & 47.45 & $1.01 \mathrm{E}-07$ & $1.10 \mathrm{E}-02$ & $2.24 \mathrm{E}+04$ \\
\hline $25 \mathrm{H}$ & 49.45 & $3.24 \mathrm{E}-07$ & $1.90 \mathrm{E}-02$ & $3.86 \mathrm{E}+04$ \\
\hline $26 \mathrm{H}$ & 51.45 & $6.70 \mathrm{E}-08$ & $2.85 \mathrm{E}-03$ & $5.79 \mathrm{E}+03$ \\
\hline $27 \mathrm{H}$ & 53.45 & $5.12 \mathrm{E}-07$ & $4.40 \mathrm{E}-02$ & $8.93 \mathrm{E}+04$ \\
\hline $28 \mathrm{H}$ & 55.45 & $6.97 \mathrm{E}-08$ & $8.98 \mathrm{E}-03$ & $1.82 \mathrm{E}+04$ \\
\hline $29 \mathrm{H}$ & 57.45 & $4.38 \mathrm{E}-08$ & $1.09 \mathrm{E}-02$ & $2.21 \mathrm{E}+04$ \\
\hline $30 \mathrm{H}$ & 59.45 & $7.36 \mathrm{E}-07$ & $3.18 \mathrm{E}-02$ & $6.46 \mathrm{E}+04$ \\
\hline $31 \mathrm{H}$ & 61.45 & $2.43 \mathrm{E}-09$ & $2.16 \mathrm{E}-03$ & $4.38 \mathrm{E}+03$ \\
\hline $32 \mathrm{H}$ & 63.45 & $1.50 \mathrm{E}-08$ & $8.89 \mathrm{E}-03$ & $1.80 \mathrm{E}+04$ \\
\hline $34 \mathrm{H}$ & 67.45 & $3.53 \mathrm{E}-09$ & $1.61 \mathrm{E}-03$ & $3.27 \mathrm{E}+03$ \\
\hline $36 \mathrm{H}$ & 71.45 & $1.53 \mathrm{E}-08$ & $2.69 \mathrm{E}-02$ & $5.47 \mathrm{E}+04$ \\
\hline $39 \mathrm{H}$ & 76.75 & $1.91 \mathrm{E}-08$ & 7.14E-03 & $1.45 \mathrm{E}+04$ \\
\hline $40 \mathrm{H}$ & 80.05 & $1.98 \mathrm{E}-09$ & $2.73 \mathrm{E}-03$ & $5.54 \mathrm{E}+03$ \\
\hline $41 \mathrm{H}$ & 83.35 & $9.19 \mathrm{E}-09$ & $4.74 \mathrm{E}-04$ & $9.62 \mathrm{E}+02$ \\
\hline $42 \mathrm{H}$ & 86.65 & $3.33 \mathrm{E}-08$ & 1.09E-01 & $2.22 \mathrm{E}+05$ \\
\hline
\end{tabular}

Liner fluid

\begin{tabular}{|c|c|c|c|c|}
\hline $1 \mathrm{H}$ & 1.15 & $1.1 \mathrm{E}-07$ & NA & NA \\
\hline $2 \mathrm{H}$ & 3.45 & $1.97 \mathrm{E}-07$ & NA & NA \\
\hline $3 \mathrm{H}$ & 5.23 & $2.73 \mathrm{E}-07$ & NA & NA \\
\hline $4 \mathrm{H}$ & 6.72 & $1.01 \mathrm{E}-07$ & NA & NA \\
\hline $4 \mathrm{H}$ & 6.72 & $1.04 \mathrm{E}-07$ & NA & NA \\
\hline $5 \mathrm{H}$ & 9.07 & $2.18 \mathrm{E}-05$ & NA & NA \\
\hline $5 \mathrm{H}$ & 9.07 & $2.19 \mathrm{E}-05$ & NA & NA \\
\hline $7 \mathrm{H}$ & 13.20 & $8.48 \mathrm{E}-07$ & NA & NA \\
\hline $9 \mathrm{H}$ & 17.25 & $8.94 \mathrm{E}-06$ & NA & NA \\
\hline $10 \mathrm{H}$ & 18.95 & $5.54 \mathrm{E}-05$ & NA & NA \\
\hline $11 \mathrm{H}$ & 21.25 & $1.18 \mathrm{E}-05$ & NA & NA \\
\hline $11 \mathrm{H}$ & 21.25 & $1.19 \mathrm{E}-05$ & NA & NA \\
\hline $12 \mathrm{H}$ & 23.45 & $1.58 \mathrm{E}-04$ & NA & NA \\
\hline $13 \mathrm{H}$ & 24.95 & $1.78 \mathrm{E}-05$ & NA & NA \\
\hline $15 \mathrm{H}$ & 28.95 & $1.72 \mathrm{E}-06$ & NA & NA \\
\hline $15 \mathrm{H}$ & 28.95 & $1.94 \mathrm{E}-06$ & NA & NA \\
\hline $16 \mathrm{H}$ & 31.45 & $2.98 \mathrm{E}-06$ & NA & NA \\
\hline $17 \mathrm{H}$ & 33.32 & $1.65 \mathrm{E}-05$ & NA & NA \\
\hline $18 \mathrm{H}$ & 35.44 & $8.40 \mathrm{E}-06$ & NA & NA \\
\hline
\end{tabular}


Table T13 (continued).

\begin{tabular}{|c|c|c|c|c|}
\hline Core & $\begin{array}{l}\text { Depth } \\
\text { (mbsf) }\end{array}$ & $\begin{array}{l}\text { PFC } \\
(\mathrm{g} / \mathrm{L})\end{array}$ & $\begin{array}{l}\text { LF fraction } \\
\text { in sample }\end{array}$ & $\begin{array}{l}\text { Contaminant } \\
\text { (cells } / \mathrm{cm}^{3} \text { ) }\end{array}$ \\
\hline $19 \mathrm{H}$ & 37.45 & $1.10 \mathrm{E}-05$ & NA & NA \\
\hline $19 \mathrm{H}$ & 37.45 & $2.27 \mathrm{E}-06$ & NA & NA \\
\hline $20 \mathrm{H}$ & 39.45 & $3.75 \mathrm{E}-06$ & NA & NA \\
\hline $21 \mathrm{H}$ & 41.03 & $1.33 \mathrm{E}-06$ & NA & NA \\
\hline $21 \mathrm{H}$ & 41.03 & $1.30 \mathrm{E}-06$ & NA & NA \\
\hline $22 \mathrm{H}$ & 43.45 & $1.68 \mathrm{E}-05$ & NA & NA \\
\hline $22 \mathrm{H}$ & 43.45 & $1.44 \mathrm{E}-05$ & NA & NA \\
\hline $22 \mathrm{H}$ & 43.45 & $1.49 \mathrm{E}-05$ & NA & NA \\
\hline $23 \mathrm{H}$ & 45.45 & $1.16 \mathrm{E}-05$ & NA & NA \\
\hline $24 \mathrm{H}$ & 47.45 & $9.71 \mathrm{E}-06$ & NA & NA \\
\hline $24 \mathrm{H}$ & 47.45 & $8.63 \mathrm{E}-06$ & NA & NA \\
\hline $25 \mathrm{H}$ & 49.45 & $1.71 \mathrm{E}-05$ & NA & NA \\
\hline $26 \mathrm{H}$ & 51.45 & $2.35 \mathrm{E}-05$ & NA & NA \\
\hline $26 \mathrm{H}$ & 51.45 & $2.27 \mathrm{E}-05$ & NA & NA \\
\hline $27 \mathrm{H}$ & 53.45 & $1.16 \mathrm{E}-05$ & NA & NA \\
\hline $28 \mathrm{H}$ & 55.45 & $7.76 \mathrm{E}-06$ & NA & NA \\
\hline $29 \mathrm{H}$ & 57.45 & $3.94 \mathrm{E}-06$ & NA & NA \\
\hline $29 \mathrm{H}$ & 57.45 & $4.11 \mathrm{E}-06$ & NA & NA \\
\hline $30 \mathrm{H}$ & 59.45 & $2.31 \mathrm{E}-05$ & NA & NA \\
\hline $31 \mathrm{H}$ & 61.45 & $1.12 \mathrm{E}-06$ & NA & NA \\
\hline $32 \mathrm{H}$ & 63.45 & $1.69 \mathrm{E}-06$ & NA & NA \\
\hline $34 \mathrm{H}$ & 67.45 & $2.21 \mathrm{E}-06$ & NA & NA \\
\hline $34 \mathrm{H}$ & 67.45 & $2.18 \mathrm{E}-06$ & NA & NA \\
\hline $36 \mathrm{H}$ & 71.45 & $5.69 \mathrm{E}-07$ & NA & NA \\
\hline $36 \mathrm{H}$ & 71.45 & $5.81 \mathrm{E}-07$ & NA & NA \\
\hline $39 \mathrm{H}$ & 76.75 & $2.60 \mathrm{E}-06$ & NA & NA \\
\hline $39 \mathrm{H}$ & 76.75 & $2.76 \mathrm{E}-06$ & NA & NA \\
\hline $40 \mathrm{H}$ & 80.05 & $7.12 \mathrm{E}-07$ & NA & NA \\
\hline $40 \mathrm{H}$ & 80.05 & $7.40 \mathrm{E}-07$ & NA & NA \\
\hline $41 \mathrm{H}$ & 83.35 & $2.01 \mathrm{E}-05$ & NA & NA \\
\hline $41 \mathrm{H}$ & 83.35 & 1.87E-05 & NA & NA \\
\hline $42 \mathrm{H}$ & 86.65 & $3.06 \mathrm{E}-07$ & NA & NA \\
\hline $42 \mathrm{H}$ & 86.65 & $3.03 \mathrm{E}-07$ & NA & NA \\
\hline \multicolumn{5}{|c|}{ Drilling fluid } \\
\hline $1 \mathrm{H}$ & 1.15 & $1.22 \mathrm{E}-06$ & NA & NA \\
\hline $1 \mathrm{H}$ & 1.15 & 1.97E-07 & NA & NA \\
\hline $1 \mathrm{H}$ & 1.15 & $6.78 \mathrm{E}-08$ & NA & NA \\
\hline $6 \mathrm{H}$ & 10.00 & $6.44 \mathrm{E}-08$ & NA & NA \\
\hline $8 \mathrm{H}$ & 14.00 & $4.21 \mathrm{E}-07$ & NA & NA \\
\hline $8 \mathrm{H}$ & 14.00 & $4.11 \mathrm{E}-07$ & NA & NA \\
\hline $11 \mathrm{H}$ & 21.25 & $2.25 \mathrm{E}-06$ & NA & NA \\
\hline $11 \mathrm{H}$ & 21.25 & $2.40 \mathrm{E}-06$ & NA & NA \\
\hline $11 \mathrm{H}$ & 21.25 & $7.83 \mathrm{E}-06$ & NA & NA \\
\hline $11 \mathrm{H}$ & 21.25 & $8.12 \mathrm{E}-06$ & NA & NA \\
\hline $11 \mathrm{H}$ & 21.25 & $1.15 \mathrm{E}-06$ & NA & NA \\
\hline $20 \mathrm{H}$ & 39.45 & $1.74 \mathrm{E}-05$ & NA & NA \\
\hline $20 \mathrm{H}$ & 39.45 & $1.82 \mathrm{E}-05$ & NA & NA \\
\hline $20 \mathrm{H}$ & 39.45 & 3.77E-05 & NA & NA \\
\hline $30 \mathrm{H}$ & 59.45 & $1.10 \mathrm{E}-05$ & NA & NA \\
\hline $30 \mathrm{H}$ & 59.45 & $1.04 \mathrm{E}-05$ & NA & NA \\
\hline $30 \mathrm{H}$ & 59.45 & $2.14 \mathrm{E}-04$ & NA & NA \\
\hline $30 \mathrm{H}$ & 59.45 & $1.99 \mathrm{E}-04$ & NA & NA \\
\hline $40 \mathrm{H}$ & 80.05 & $1.33 \mathrm{E}-08$ & NA & NA \\
\hline $40 \mathrm{H}$ & 80.05 & $1.18 \mathrm{E}-08$ & NA & NA \\
\hline $40 \mathrm{H}$ & 80.05 & $8.24 \mathrm{E}-07$ & NA & NA \\
\hline $40 \mathrm{H}$ & 80.05 & $8.21 \mathrm{E}-07$ & NA & NA \\
\hline
\end{tabular}

The contaminant cell numbers in samples represent an estimated potential maximum. PFC = perfluorocarbon tracer, $\mathrm{LF}=$ liner fluid; $\mathrm{BD}=\mathrm{below}$ detection; NA = not applicable. 
Table T14. Composite depth scale, Site M0063.

\begin{tabular}{|c|c|c|c|}
\hline \multirow[b]{2}{*}{ Core } & \multirow{2}{*}{$\begin{array}{c}\text { Offset } \\
(\mathrm{m})\end{array}$} & \multicolumn{2}{|c|}{ Top depth } \\
\hline & & (mbsf) & (mcd) \\
\hline \multicolumn{4}{|c|}{ 347-M0063A- } \\
\hline $1 \mathrm{P}$ & 0 & 0 & 0 \\
\hline $2 \mathrm{H}$ & 0 & 0 & 0 \\
\hline $3 \mathrm{H}$ & 0 & 3.3 & 3.3 \\
\hline $4 \mathrm{H}$ & 0 & 6.6 & 6.6 \\
\hline $5 \mathrm{H}$ & 0 & 9.9 & 9.9 \\
\hline $6 \mathrm{H}$ & 0 & 13.2 & 13.2 \\
\hline $7 \mathrm{H}$ & 0 & 16.5 & 16.5 \\
\hline $8 \mathrm{H}$ & 0 & 19.5 & 19.5 \\
\hline $9 \mathrm{H}$ & 0 & 22.8 & 22.8 \\
\hline $10 \mathrm{H}$ & 0 & 26.1 & 26.1 \\
\hline $11 \mathrm{H}$ & 0 & 29.4 & 29.4 \\
\hline $12 \mathrm{H}$ & 0 & 32.7 & 32.7 \\
\hline $13 \mathrm{H}$ & 0 & 36 & 36 \\
\hline $14 \mathrm{H}$ & 0 & 39.3 & 39.3 \\
\hline $15 \mathrm{H}$ & 0 & 42.6 & 42.6 \\
\hline $16 \mathrm{H}$ & 0 & 45.9 & 45.9 \\
\hline $17 \mathrm{H}$ & 0 & 49.2 & 49.2 \\
\hline $18 \mathrm{H}$ & 0 & 52.5 & 52.5 \\
\hline $19 \mathrm{H}$ & 0 & 55.8 & 55.8 \\
\hline $20 \mathrm{H}$ & 0 & 59.1 & 59.1 \\
\hline $21 \mathrm{H}$ & 0 & 62.4 & 62.4 \\
\hline $22 \mathrm{H}$ & 0 & 65.7 & 65.7 \\
\hline $23 \mathrm{H}$ & 0 & 69 & 69 \\
\hline $24 \mathrm{H}$ & 0 & 72.3 & 72.3 \\
\hline $25 \mathrm{H}$ & 0 & 75.6 & 75.6 \\
\hline $26 \mathrm{H}$ & 0 & 78.9 & 78.9 \\
\hline $27 \mathrm{H}$ & 0 & 82.2 & 82.2 \\
\hline $28 \mathrm{H}$ & 0 & 85.5 & 85.5 \\
\hline $29 \mathrm{H}$ & 0 & 88.8 & 88.8 \\
\hline $30 \mathrm{H}$ & 0 & 92.1 & 92.1 \\
\hline $31 \mathrm{H}$ & 0 & 93.9 & 93.9 \\
\hline $32 X$ & 0 & 95.8 & 95.8 \\
\hline $33 x$ & 0 & 96.8 & 96.8 \\
\hline $34 P$ & 0 & 97.8 & 97.8 \\
\hline 350 & 0 & 98.8 & 98.8 \\
\hline $36 P$ & 0 & 101.8 & 101.8 \\
\hline $39 S$ & 0 & 105.8 & 105.8 \\
\hline $41 \mathrm{~S}$ & 0 & 115.8 & 115.8 \\
\hline
\end{tabular}

\begin{tabular}{|c|c|c|c|}
\hline \multirow[b]{2}{*}{ Core } & \multirow{2}{*}{$\begin{array}{l}\text { Offset } \\
(\mathrm{m})\end{array}$} & \multicolumn{2}{|c|}{ Top depth } \\
\hline & & (mbsf) & (mcd) \\
\hline $8 \mathrm{H}$ & 0.62 & 14 & 14.62 \\
\hline $9 \mathrm{H}$ & 0.89 & 16 & 16.89 \\
\hline $10 \mathrm{H}$ & 1.41 & 18 & 19.41 \\
\hline $11 \mathrm{H}$ & 0.89 & 20 & 20.89 \\
\hline $12 \mathrm{H}$ & 0.89 & 22 & 22.89 \\
\hline $13 \mathrm{H}$ & 0.89 & 24 & 24.89 \\
\hline $14 \mathrm{H}$ & -0.1 & 26 & 25.9 \\
\hline $15 \mathrm{H}$ & -0.33 & 28 & 27.67 \\
\hline $16 \mathrm{H}$ & -0.92 & 30 & 29.08 \\
\hline $17 \mathrm{H}$ & -0.62 & 32 & 31.38 \\
\hline $18 \mathrm{H}$ & 0.73 & 34 & 34.73 \\
\hline $19 \mathrm{H}$ & 1.79 & 36 & 37.79 \\
\hline $20 \mathrm{H}$ & 2.71 & 38 & 40.71 \\
\hline $21 \mathrm{H}$ & 2.71 & 40 & 42.71 \\
\hline $22 \mathrm{H}$ & 2.71 & 42 & 44.71 \\
\hline $23 \mathrm{H}$ & 1.77 & 44 & 45.77 \\
\hline $24 \mathrm{H}$ & 0.81 & 46 & 46.81 \\
\hline $25 \mathrm{H}$ & 0.81 & 48 & 48.81 \\
\hline $26 \mathrm{H}$ & 0.81 & 50 & 50.81 \\
\hline $27 \mathrm{H}$ & 0.32 & 52 & 52.32 \\
\hline $28 \mathrm{H}$ & 0.32 & 54.5 & 54.82 \\
\hline $29 \mathrm{H}$ & 0.39 & 57.8 & 58.19 \\
\hline $30 \mathrm{H}$ & 0.16 & 61.1 & 61.26 \\
\hline $31 \mathrm{H}$ & 0.16 & 64.4 & 64.56 \\
\hline $32 \mathrm{H}$ & 0.39 & 67.7 & 68.09 \\
\hline $33 \mathrm{H}$ & 0.16 & 71 & 71.16 \\
\hline $34 \mathrm{H}$ & 0.16 & 74.3 & 74.46 \\
\hline $35 \mathrm{H}$ & 0.16 & 77.6 & 77.76 \\
\hline $36 \mathrm{H}$ & 0.26 & 80.9 & 81.16 \\
\hline $37 \mathrm{H}$ & 0.39 & 84.2 & 84.59 \\
\hline $38 \mathrm{H}$ & 0.36 & 87.5 & 87.86 \\
\hline $39 \mathrm{H}$ & 0.74 & 90.8 & 91.54 \\
\hline 400 & 0.74 & 93.3 & 94.04 \\
\hline $41 \mathrm{~s}$ & 0.74 & 96.3 & 97.04 \\
\hline
\end{tabular}

\begin{tabular}{lcll}
\hline & \multirow{2}{*}{$\begin{array}{c}\text { Offset } \\
\text { Core }\end{array}$} & $(\mathrm{m})$ & \multicolumn{2}{c}{ Top depth } \\
\cline { 3 - 4 } & & (mbsf) & (mcd) \\
\hline $28 \mathrm{H}$ & 0.2 & 52.5 & 52.7 \\
$29 \mathrm{O}$ & 0.2 & 54 & 54.2 \\
$30 \mathrm{H}$ & 0.2 & 54.2 & 54.4 \\
$31 \mathrm{H}$ & 0.2 & 56.2 & 56.4 \\
$32 \mathrm{H}$ & -0.03 & 58.7 & 58.67 \\
$33 \mathrm{H}$ & 0.72 & 61.2 & 61.92 \\
$34 \mathrm{H}$ & 0.72 & 63.7 & 64.42 \\
$35 \mathrm{H}$ & 0.72 & 67 & 67.72 \\
$36 \mathrm{H}$ & 0.66 & 67.6 & 68.26 \\
$37 \mathrm{H}$ & -0.17 & 70.3 & 70.13 \\
$38 \mathrm{H}$ & -0.17 & 73.6 & 73.43 \\
$39 \mathrm{H}$ & 0.29 & 76.9 & 77.19 \\
$40 \mathrm{H}$ & 0.29 & 80.2 & 80.49 \\
$41 \mathrm{H}$ & 0.36 & 83.5 & 83.86
\end{tabular}

347-M0063E-

\begin{tabular}{|c|c|c|c|}
\hline \\
\hline $1 \mathrm{H}$ & -0.12 & 0 & -0.12 \\
\hline $2 \mathrm{H}$ & -0.12 & 2 & 1.88 \\
\hline $3 \mathrm{H}$ & -0.27 & 4 & 3.73 \\
\hline $4 \mathrm{H}$ & -0.12 & 6 & 5.88 \\
\hline $5 \mathrm{H}$ & -0.7 & 8 & 7.3 \\
\hline $6 \mathrm{H}$ & -1.41 & 10 & 8.59 \\
\hline $7 \mathrm{H}$ & -1.41 & 12 & 10.59 \\
\hline $8 \mathrm{H}$ & -0.32 & 14 & 13.68 \\
\hline $9 \mathrm{H}$ & 0.05 & 16 & 16.05 \\
\hline $10 \mathrm{H}$ & 0.88 & 18 & 18.88 \\
\hline $11 \mathrm{H}$ & -0.35 & 20 & 19.65 \\
\hline $12 \mathrm{H}$ & 0.38 & 22 & 22.38 \\
\hline $13 \mathrm{H}$ & -0.04 & 24 & 23.96 \\
\hline $14 \mathrm{H}$ & -0.59 & 26 & 25.41 \\
\hline $15 \mathrm{H}$ & -0.36 & 28 & 27.64 \\
\hline $16 \mathrm{H}$ & -0.46 & 30 & 29.54 \\
\hline $17 \mathrm{H}$ & -0.56 & 32 & 31.44 \\
\hline $18 \mathrm{H}$ & -0.03 & 34 & 33.97 \\
\hline $19 \mathrm{H}$ & -0.61 & 36 & 35.39 \\
\hline $20 \mathrm{H}$ & -0.86 & 38 & 37.14 \\
\hline $21 \mathrm{H}$ & 0.56 & 40 & 40.56 \\
\hline $22 \mathrm{H}$ & 0.99 & 42 & 42.99 \\
\hline $23 \mathrm{H}$ & 0.45 & 44 & 44.45 \\
\hline $24 \mathrm{H}$ & -0.8 & 46 & 45.2 \\
\hline $25 \mathrm{H}$ & -0.46 & 48 & 47.54 \\
\hline $26 \mathrm{H}$ & -0.54 & 50 & 49.46 \\
\hline $27 \mathrm{H}$ & -0.56 & 52 & 51.44 \\
\hline $28 \mathrm{H}$ & -1.33 & 54 & 52.67 \\
\hline $29 \mathrm{H}$ & -1.33 & 56 & 54.67 \\
\hline $30 \mathrm{H}$ & -1.33 & 58 & 56.67 \\
\hline $31 \mathrm{H}$ & -1.33 & 60 & 58.67 \\
\hline $32 \mathrm{H}$ & -1.33 & 62 & 60.67 \\
\hline $33 \mathrm{H}$ & -1.01 & 64 & 62.99 \\
\hline $34 \mathrm{H}$ & -0.27 & 66 & 65.73 \\
\hline $35 \mathrm{H}$ & 1.19 & 68 & 69.19 \\
\hline $36 \mathrm{H}$ & 1.8 & 70 & 71.8 \\
\hline $37 \mathrm{H}$ & 1.45 & 72 & 73.45 \\
\hline 380 & 1.45 & 74 & 75.45 \\
\hline $39 \mathrm{H}$ & 0.57 & 75.3 & 75.87 \\
\hline $40 \mathrm{H}$ & 0.11 & 78.6 & 78.71 \\
\hline $41 \mathrm{H}$ & 0.36 & 81.9 & 82.26 \\
\hline $42 \mathrm{H}$ & 0.57 & 85.2 & 85.77 \\
\hline $43 \mathrm{H}$ & 1.46 & 88.5 & 89.96 \\
\hline $44 \mathrm{H}$ & 1.46 & 91.8 & 93.26 \\
\hline
\end{tabular}


Table T15. Sound velocity data for lithostratigraphic units, Site M0063.

\begin{tabular}{lrccrr}
\hline \multicolumn{1}{c}{ Unit } & $\begin{array}{c}\text { Thickness } \\
\text { of unit } \\
(\mathrm{m})\end{array}$ & $\begin{array}{c}\text { Sound } \\
\text { velocity } \\
(\mathrm{m} / \mathrm{s})\end{array}$ & $\begin{array}{c}\text { TWT } \\
(\mathrm{ms})\end{array}$ & $\begin{array}{c}\text { Depth } \\
(\mathrm{m})\end{array}$ & $\begin{array}{r}\text { Depth } \\
(\mathrm{mbsf})\end{array}$ \\
\hline Water & 437 & 1430 & 0.6112 & 437 & 0 \\
I Organic-rich clay & 25 & 1229 & 0.6314 & 462 & 25 \\
II Gray clay & 9 & 1305 & 0.6448 & 471 & 34 \\
III Deformed clay & 7 & 1465 & 0.6543 & 478 & 41 \\
IV Iron sulfide laminated clay & 7 & 1490 & 0.6634 & 485 & 48 \\
V Convolute bedded clay & 5 & 1424 & 0.6708 & 490 & 53 \\
VI Varved clay & 39 & 1407 & 0.7258 & 529 & 92 \\
\hline
\end{tabular}

${ }^{*}=$ sound velocities are based on values measured during the OSP. TWT = two-way traveltime. 